UNIVERSIDADE ESTADUAL PAULISTA “JULIO DE MESQUITA FILHO” FACULDADE DE CIÊNCIAS AGRONÔMICAS CAMPUS DE BOTUCATU

\title{
AVALIAÇÃO DE EFICIÊNCIA RELATIVA PARA A REATIVIDADE EM SILICATOS
}

\section{ANGÉLICA CRISTINA FERNANDES DEUS}

Dissertação apresentada à Faculdade de Ciências Agronômicas da Unesp - Campus de Botucatu, para obtenção do título de Mestre em Agronomia (Agricultura).

BOTUCATU-SP

Fevereiro - 2010 
UNIVERSIDADE ESTADUAL PAULISTA “JULIO DE MESQUITA FILHO” FACULDADE DE CIÊNCIAS AGRONÔMICAS CAMPUS DE BOTUCATU

\title{
AVALIAÇÃO DE EFICIÊNCIA RELATIVA PARA A REATIVIDADE EM SILICATOS
}

\author{
ANGÉLICA CRISTINA FERNANDES DEUS \\ Engenheira Agrônoma
}

Orientador: Prof. Dr. Leonardo Theodoro Büll

Dissertação apresentada à Faculdade de Ciências Agronômicas da Unesp - Campus de Botucatu, para obtenção do título de Mestre em Agronomia (Agricultura).

BOTUCATU-SP

Fevereiro - 2010 


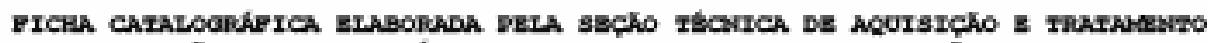

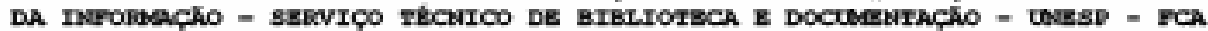
- LAOEADO - BOTOCASU (SD)

D486a

Deus, Angélica Cristina Fernandes, 1983-

Avaliaçäo de eficiência relativa para a reatividade em silicatos / Angélica Cristina Fernandes Deus. - Botucatu. [s.n. $], 2010$. xiii, $113 \mathrm{f}$. : gráfs., tabs.

Dissertação (Mestrado) - Universidade Bstadual Paulista, Faculdade de Ciências Agronônicas, Botucatu, 2010 Orientador: Ieonardo Theodoro Büll' Inclui bibliografia.

1. Silicatos. 2. Reatividade. 3. Corretivos de acides do solo. I. Büll, Ieonardo Theodoro. II. Universidade Estadual Paulista "Júlio de Mesquita Filho" (Campus de Botucatu). Faculdade de Ciências Agronômicas. III. Título. 
UNIVERSIDADE ESTADUAL PAULISTA "JÚLIO DE MESQUTTA FLLHO" FACULDADE DE CIÊNCIAS AGRONÔMICAS

CAMPUS DE BOTUCATU

\section{CERTIFICADO DE APROVAÇĀO}

\section{TITUlO: AVALIAÇÃO DE EFICIÊNCIA RELATIVA PARA A REATIVIdAdE EM SILICATOS}

\section{ALUNA: ANGÉLICA CRISTINA FERNANDES DEUS}

ORIENTADOR: PROF. DR. LEONARDO THEODORO BÛLL

Aprovado pela Comissão Examinadora

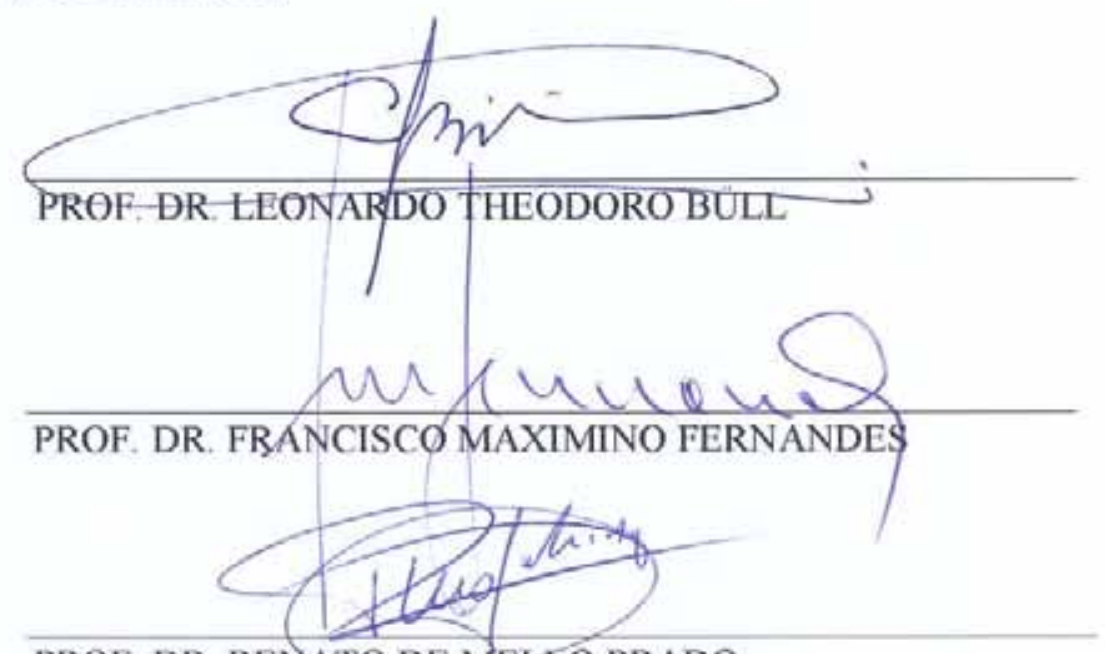

PROF. DR. RENATO DE MEELO PRADO

Data da Realizaçāo: 09 de fevereiro de 2010. 
"A felicidade aparece para aqueles que choram.

Para aqueles que se machucam.

Para aqueles que buscam e tentam sempre.

E para aqueles que reconhecem a importância das pessoas que passam por suas vidas"

Clarice Lispector 
Aos meus pais, por confiarem, incentivarem, e me apoiarem em todos os momentos da minha vida.

\section{DEDICO}




\section{AGRADECIMENTOS}

A Deus, sempre e acima de tudo;

À Universidade Estadual Paulista "Julio de Mesquita Filho", Faculdade de Ciências Agronômicas Campus de Botucatu por proporcionar a realização do Mestrado;

Ao Prof ${ }^{0}$ Dr. Leonardo Theodoro Büll, pela dedicada orientação e confiança no meu trabalho;

À Fundação de Amparo à Pesquisa do Estado de São Paulo, pela concessão de bolsa de estudo e financiamento do projeto de pesquisa;

Às empresas Mannesmann; Silifertil; J. Reminas Mineração; Recmix Agrosílico pela doação dos silicatos e a empresa AGMAX pela disponibilização das sementes de alfafa;

À Prof ${ }^{\mathrm{a}}$. Dr ${ }^{\mathrm{a}}$ Martha M. Mischan pelo auxílio na parte estatística;

Ao Prof. Dr. Dirceu Maximino Fernandes e ao Prof. Dr. Roberto Lyra Villas Boas pela atenção e apoio dispensados;

A todos os funcionários do Departamento de Recursos Naturais/Área de Ciência do Solo, pela colaboração sempre que precisei;

À estagiária e amiga Mariana Tranquilino de Souza, pelo auxílio na condução dos experimentos;

Ao Eng $^{\circ}$ Agrônomo Juliano Corulli Corrêa pelo apoio nos momentos iniciais do projeto;

Ao Eng ${ }^{\circ}$ Agrônomo Nelson Geraldo de Oliveira pela disposição em sempre ajudar;

As amigas Carla e Deise, por toda ajuda, amizade e convivência fraterna;

A todos os amigos que conquistei durante o período do mestrado. 


\section{SUMÁRIO}

Página

LISTA DE TABELAS............................................................................................ VII

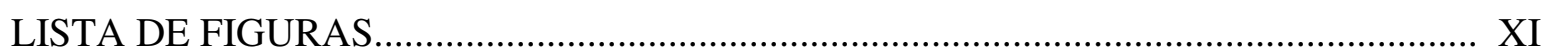

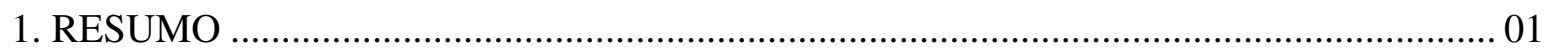

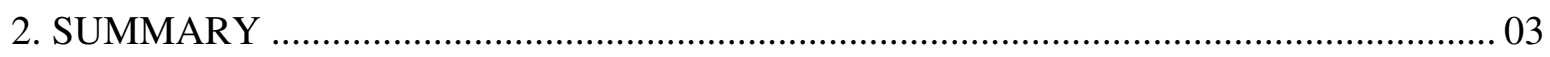

3. INTRODUÇÃ

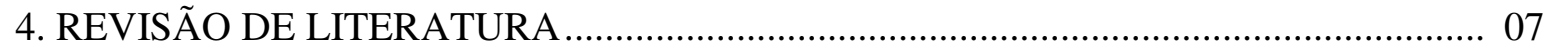

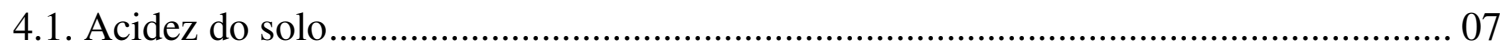

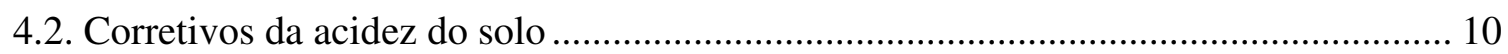

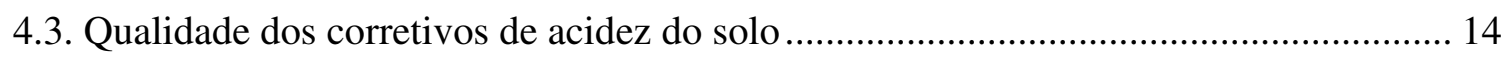

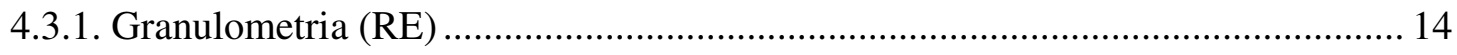

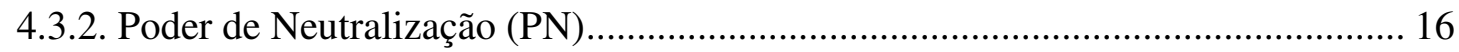

4.3.3. Poder Relativo de Neutralização Total (PRNT) ................................................... 18

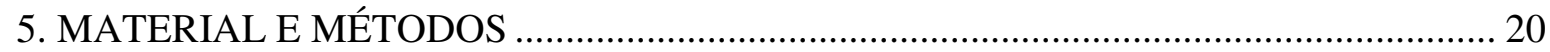

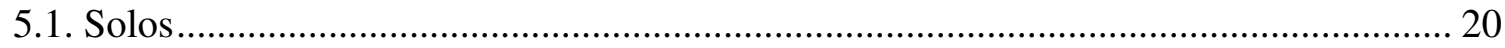

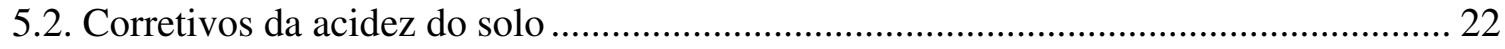

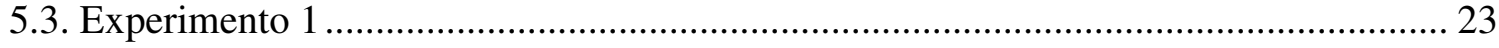

5.3.1 Descrição dos tratamentos, delineamento experimental e análise estatística ........ 23

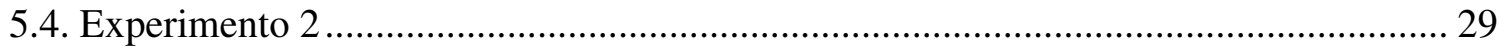

5.4.1. Descrição dos tratamentos, delineamento experimental e análise estatística ....... 29

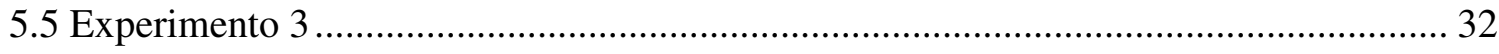

5.5.1. Descrição dos tratamentos, delineamento experimental e análise estatística ....... 32

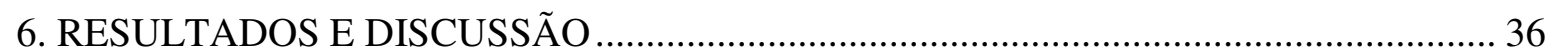


Página

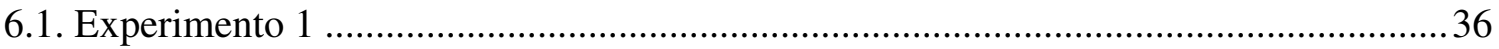

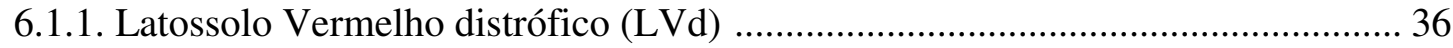

6.1.2. Nitossolo Vermelho eutrófico (NVe) ...................................................................... 39

6.1.3. Neossolo Quartzarênico (NQ) .......................................................................... 41

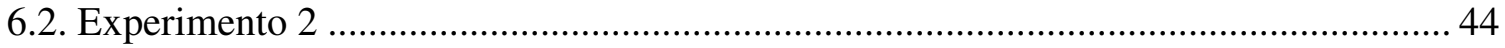

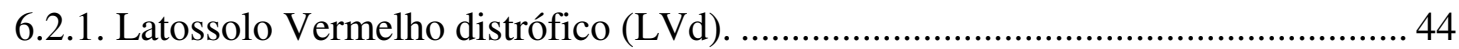

6.2.2. Nitossolo Vermelho eutrófico (NVe) ....................................................................55

6.2.3. Neossolo Quartzarênico (NQ) ........................................................................67

6.2.4. Eficiência relativa de reatividade de frações granulométricas dos materiais

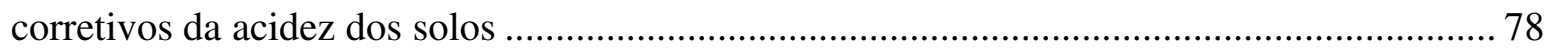

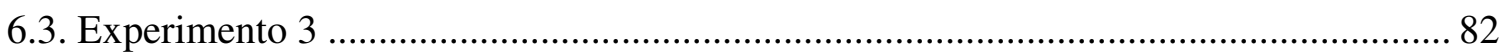

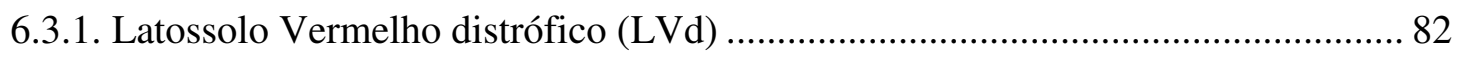

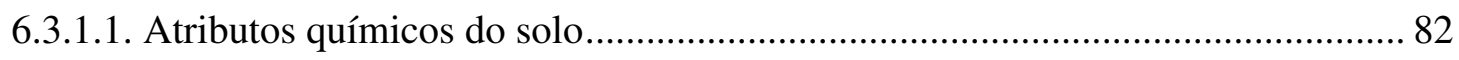

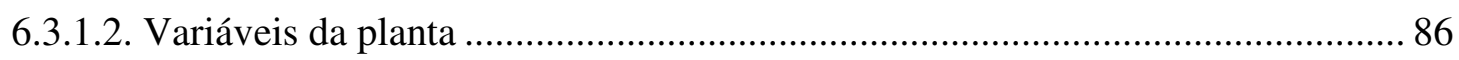

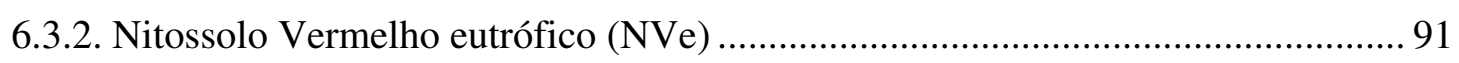

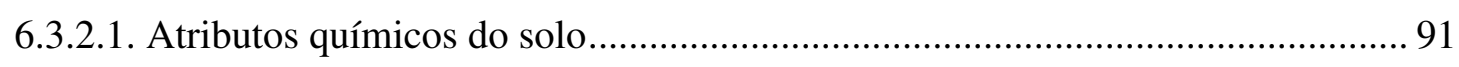

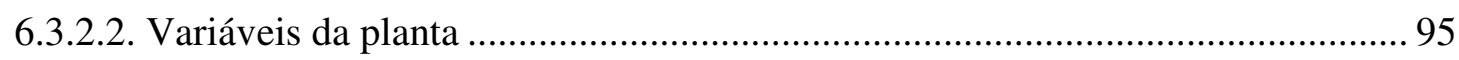

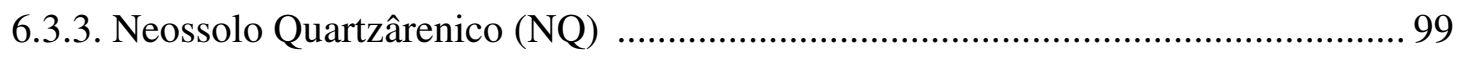

6.3.3.1. Atributos químicos do solo.................................................................................. 99

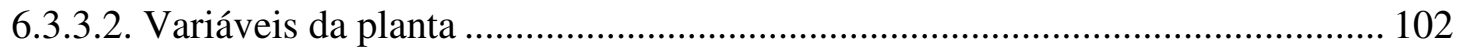

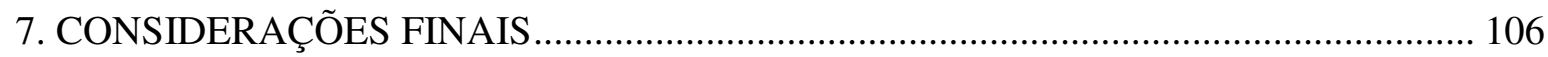

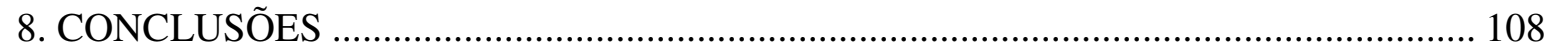

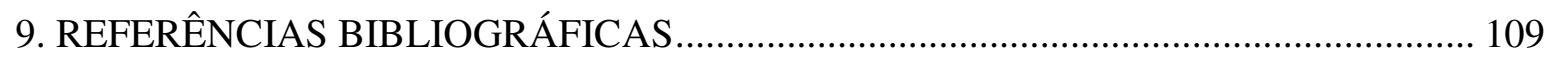




\section{LISTA DE TABELAS}

Página

Tabela 1. Caracterização química e textural dos solos

Tabela 2. Análises químicas e físicas dos corretivos de acidez do solo utilizados no experimento

Tabela 3. Equações e doses dos materiais corretivos necessárias para elevar o pH do Latossolo Vermelho distrófico (LVd) a 5,5 de acordo com as frações granulométricas, obtidas no período de 90 dias de incubação.

Tabela 4. Equações e doses dos materiais corretivos necessárias para elevar o pH do Neossolo Quartzarênio (NQ) a 5,5 de acordo com as frações granulométricas, obtidas no período de 90 dias de incubação.

Tabela 5. Equações e doses dos materiais corretivos necessárias para elevar o pH do Nitossolo Vermelho eutrófico (NVe) a 5,5 de acordo com as frações granulométricas, , obtidas no período de 90 dias de incubação. 28

Tabela 6. Valores de PRNT laboratório e experimento, em função dos corretivos . 31

Tabela 7. Doses dos corretivos de acidez utilizadas no terceiro experimento 34

Tabela 8. Desdobramento das interações corretivos x granulometrias para atributos químicos do Latossolo Vermelho distrófico (LVd) após 30 dias de incubação 46

Tabela 9. Desdobramento das interações corretivos x granulometrias para atributos químicos do Latossolo Vermelho distrófico (LVd) após 60 dias de incubação

Tabela 10. Desdobramento das interações corretivos x granulometrias para atributos químicos do Latossolo Vermelho distrófico (LVd) após 90 dias de incubação 48

Tabela 11. Atributos químicos do Latossolo Vermelho distrófico (LVd) em função da aplicação da granulometria $<0,30 \mathrm{~mm}$ (peneira fundo) dos corretivos.

Tabela 12. Desdobramento das interações corretivos x granulometrias para atributos químicos do Nitossolo Vermelho eutrófico (NVe) após 30 dias de incubação 56

Tabela 13. Desdobramento das interações corretivos x granulometrias para atributos químicos do Nitossolo Vermelho eutrófico (NVe) após 60 dias de incubação 57

Tabela 14. Desdobramento das interações corretivos x granulometrias para atributos químicos do Nitossolo Vermelho eutrófico (NVe) após 90 dias de incubação 58 
Página

Tabela 15. Atributos químicos do Nitossolo Vermelho eutrófico (NVe) em função da aplicação da fração granulométrica $<0,30 \mathrm{~mm}$ (peneira fundo) dos corretivos

Tabela 16. Desdobramento das interações corretivos $\mathrm{x}$ granulometrias para atributos químicos do Neossolo Quartzârenico (NQ) após 30 dias de incubação

Tabela 17. Desdobramento das interações corretivos x granulometrias para atributos químicos do Neossolo Quartzârenico (NQ) após 60 dias de incubação

Tabela 18. Desdobramento das interações corretivos x granulometrias para atributos químicos do Neossolo Quartzârenico (NQ) após 90 dias de incubação

Tabela 19. Atributos químicos do Neossolo Quartzârenico (NQ) em função da aplicação da fração granulométrica $<0,30 \mathrm{~mm}$ (peneira fundo) dos corretivos 77

Tabela 20. Eficiência relativa (ER) de reatividade das frações granulométricas dos materiais corretivos de acidez do solo, calculada após 90 dias de incubação 78

Tabela 21. Média da eficiência relativa (ER) das frações granulométricas dos materiais corretivos de acidez considerando os três solos 80

Tabela 22. Reatividade (RE), Poder de Neutralização (PN) e Poder Relativo de Neutralização Total (PRNT) dos corretivos de acidez do solo. 82

Tabela 23. Resultados das análises químicas do Latossolo Vermelho distrófico (LVd) em função dos tratamentos após 30 dias de incubação

Tabela 24. Resultados das análises de micronutrientes do Latossolo Vermelho distrófico (LVd) em função dos tratamentos após 30 dias de incubação

Tabela 25. Resultados das análises químicas do Latossolo Vermelho distrófico (LVd) em função dos tratamentos após o cultivo da alfafa, 90 dias após incubação

Tabela 26. Matéria seca de parte aérea da alfafa, no primeiro corte (C1) e no segundo corte (C2) em função dos tratamentos no Latossolo Vermelho distrófico (LVd). 86

Tabela 27. Teores médios de nutrientes na parte aérea de plantas de alfafa $\left(1^{\circ}\right.$ corte $)$ em função dos tratamentos no Latossolo Vermelho distrófico (LVd). 87

Tabela 28. Teores médios de nutrientes na parte aérea de plantas de alfafa $\left(2^{\circ}\right.$ corte $)$ em função dos tratamentos no Latossolo Vermelho distrófico (LVd). 88

Tabela 29. Acúmulo médio de nutrientes na parte aérea de plantas de alfafa $\left(1^{\circ}\right.$ corte) em função dos tratamentos aplicados no Latossolo Vermelho distrófico (LVd). 90 
Tabela 30. Acúmulo médio de nutrientes na parte aérea de plantas de alfafa $\left(2^{\circ}\right.$ corte) em função dos tratamentos aplicados no Latossolo Vermelho distrófico (LVd).

Tabela 31. Resultados das análises químicas do Nitossolo Vermelho eutrófico (NVe) em função dos tratamentos após 30 dias de incubação

Tabela 32. Resultados das análises de micronutrientes do Nitossolo Vermelho eutrófico (NVe) em função dos tratamentos após 30 dias de incubação

Tabela 33. Resultados das análises químicas do Nitossolo Vermelho eutrófico (NVe) em razão dos tratamentos após o cultivo da alfafa, 90 dias após incubação

Tabela 34. Matéria seca de parte aérea da alfafa, no primeiro corte (C1) e no segundo corte (C2) em função dos tratamentos no Nitossolo Vermelho eutrófico (NVe) 95

Tabela 35. Teores médios de nutrientes na parte aérea de plantas de alfafa $\left(1^{\circ}\right.$ corte) em função dos tratamentos no Nitossolo Vermelho eutrófico (NVe). 96

Tabela 36. Teores médios de nutrientes na parte aérea de plantas de alfafa ( $2^{\circ}$ corte) em função dos tratamentos no Nitossolo Vermelho eutrófico (NVe) 96

Tabela 37. Acúmulo médio de nutrientes na parte aérea de plantas de alfafa $\left(1^{\circ}\right.$ corte $) \mathrm{em}$ função dos tratamentos aplicados no Nitossolo Vermelho eutrófico (NVe) 98

Tabela 38. Acúmulo médio de nutrientes na parte aérea de plantas de alfafa ( $2^{\circ}$ corte) em função dos tratamentos aplicados no Nitossolo Vermelho eutrófico (NVe) 99

Tabela 39. Resultados das análises químicas do Neossolo Quartzarênico (NQ) em função dos tratamentos após 30 dias de incubação. 100

Tabela 40. Resultados das análises de micronutrientes do Neossolo Quartzarênico (NQ) em função dos tratamentos após 30 dias de incubação

Tabela 41. Resultados das análises químicas do Neossolo Qartzarênico (NQ) em função dos tratamentos após o cultivo da alfafa, 90 dias após incubação. 101

Tabela 42. Matéria seca de parte aérea da alfafa, no primeiro corte $(\mathrm{C} 1)$ e no segundo corte (C2) em função dos tratamentos no Neossolo Quartzarênico (NQ). 102

Tabela 43. Teores médios de nutrientes na parte aérea de plantas de alfafa $\left(1^{\circ}\right.$ corte $)$ em função dos tratamentos no Neossolo Quartzarênico (NQ). 103

Tabela 44. Teores médios de nutrientes na parte aérea de plantas de alfafa $\left(2^{\circ}\right.$ corte $)$ em função dos tratamentos no Neossolo Quartzarênico (NQ) 103 
Página

Tabela 45. Acúmulo médio de nutrientes na parte aérea de plantas de alfafa $\left(1^{\circ}\right.$ corte) em função dos tratamentos aplicados no Neossolo Quartzarênico (NQ) ..................................... 104

Tabela 46. Acúmulo médio de nutrientes na parte aérea de plantas de alfafa ( $2^{\circ}$ corte) em função dos tratamentos aplicados no Neossolo Quartzarênico (NQ) ..................................... 105 


\section{LISTA DE FIGURAS}

Página

Figura 1. Desdobramento das interações doses e granulometrias (Fundo: $\varnothing<0,30 \mathrm{~mm} ; 50: \varnothing=$ 0,30 mm; 20: $\varnothing=0,84 \mathrm{~mm} ; 10: \varnothing=2 \mathrm{~mm}$ ) para valores de $\mathrm{pH}$ do Latossolo Vermelho distrófico (LVd) com a aplicação de escória (a), silicato de cálcio (b), silicato de cálcio e magnésio (c), wollastonita ${ }^{1}$ (d), calcário calcítico (e) e calcário dolomítico (f), aos 30, 60 e 90 dias de incubação. $* *$ significativo a $1 \%$ de probabilidade. ns- não significativo. ${ }^{1}$ possui apenas a fração granulométrica $<0,30 \mathrm{~mm}$.

Figura 2. Desdobramento das interações doses e granulometrias (Fundo: $\varnothing<0,30 \mathrm{~mm} ; 50: \varnothing=$ 0,30 mm; 20: $\varnothing=0,84 \mathrm{~mm} ; 10: \varnothing=2 \mathrm{~mm}$ ) para valores de $\mathrm{pH}$ do Nitossolo Vermelho eutrófico (NVe) com a aplicação de escória (a), silicato de cálcio (b), silicato de cálcio e magnésio (c), wollastonita ${ }^{1}$ (d), calcário calcítico (e) e calcário dolomítico (f), aos 30, 60 e 90 dias de incubação. ** significativo a $1 \%$ de probabilidade. ns- não significativo. ${ }^{1}$ possui apenas a fração granulométrica $<0,30 \mathrm{~mm}$

Figura 3. Desdobramento das interações doses e granulometrias (Fundo: $\varnothing<0,30 \mathrm{~mm} ; 50: \varnothing=$ 0,30 mm; 20: $\varnothing=0,84 \mathrm{~mm} ; 10: \varnothing=2 \mathrm{~mm}$ ) para valores de $\mathrm{pH}$ do Neossolo Quartzarênico (NQ) com a aplicação de escória (a), silicato de cálcio (b), silicato de cálcio e magnésio (c), wollastonita $^{1}$ (d), calcário calcítico (e) e calcário dolomítico (f), aos 30, 60 e 90 dias de incubação. ** significativo a $1 \%$ de probabilidade. ns- não significativo. ${ }^{1}$ possui apenas a fração granulométrica $<0,30 \mathrm{~mm}$.....

Figura 4. Desdobramento das interações granulometrias (Fundo: $\varnothing<0,30 \mathrm{~mm} ; 50: \varnothing=0,30$ mm; 20: $\varnothing=0,84 \mathrm{~mm} ; 10: \varnothing=2 \mathrm{~mm}) \mathrm{x}$ períodos de incubação para valores de $\mathrm{pH}$ e $\mathrm{H}+\mathrm{Al}$ do Latossolo Vermelho distrófico (LVd) com a aplicação de escória (a), silicato de cálcio (b), silicato de cálcio e magnésio (c), wollastonita $^{1}$ (d), calcário calcítico (e) e calcário dolomítico (f). $* \mathrm{e}^{* *}$ significativos a $5 \%$ e $1 \%$ de probabilidade, respectivamente. ns- não significativo. ${ }^{1}$ possui apenas a fração granulométrica $<0,30 \mathrm{~mm}$.

Figura 5. Desdobramento das interações granulometrias (Fundo: $\varnothing<0,30 \mathrm{~mm} ; 50: \varnothing=0,30$ $\mathrm{mm}$; 20: $\varnothing=0,84 \mathrm{~mm} ; 10: \varnothing=2 \mathrm{~mm}$ ) x períodos de incubação para teores de $\mathrm{K}, \mathrm{Ca}$ e $\mathrm{Mg}$ do Latossolo Vermelho distrófico ( $\mathrm{LVd}$ ) com a aplicação de escória (a), silicato de cálcio (b), silicato de cálcio e magnésio (c), wollastonita $^{1}$ (d), calcário calcítico (e) e calcário dolomítico 
(f). $* \mathrm{e}^{* *}$ significativos a $5 \%$ e $1 \%$ de probabilidade, respectivamente. ns- não significativo. ${ }^{1}$ possui apenas a fração granulométrica $<0,30 \mathrm{~mm}$

Figura 6. Desdobramento das interações granulometrias (Fundo: $\varnothing<0,30 \mathrm{~mm} ; 50$ : $\varnothing=0,30$ $\mathrm{mm} ; 20: \varnothing=0,84 \mathrm{~mm} ; 10: \varnothing=2 \mathrm{~mm}) \mathrm{x}$ períodos de incubação para valores de SB, CTC e V\% do Latossolo Vermelho distrófico (LVd) com a aplicação de escória (a), silicato de cálcio (b), silicato de cálcio e magnésio (c), wollastonita ${ }^{1}$ (d), calcário calcítico (e) e calcário dolomítico (f).* e $* *$ significativos a $5 \%$ e $1 \%$ de probabilidade, respectivamente. ns- não significativo. ${ }^{1}$ possui apenas a fração granulométrica $<0,30 \mathrm{~mm}$.

Figura 7. Desdobramento das interações granulometrias (Fundo: $\varnothing<0,30 \mathrm{~mm} ; 50$ : $\varnothing=0,30$ mm; 20: $\varnothing=0,84 \mathrm{~mm} ; 10: \varnothing=2 \mathrm{~mm}$ ) x períodos de incubação para valores de $\mathrm{pH}$ e H+Al do Nitossolo Vermelho eutrófico (NVe) com a aplicação de escória (a), silicato de cálcio (b), silicato de cálcio e magnésio (c), wollastonita ${ }^{1}$ (d), calcário calcítico (e) e calcário dolomítico (f). $* \mathrm{e}^{* *}$ significativos a $5 \%$ e $1 \%$ de probabilidade, respectivamente. ns- não significativo. ${ }^{1}$ possui apenas a fração granulométrica $<0,30 \mathrm{~mm}$ 59

Figura 8. Valores de K no Nitossolo Vermelho eutrófico (NVe) em função dos períodos de incubação de escória (a), calcário calcítico (b) e calcário dolomítico (c). ** significativo a $1 \%$ de probabilidade

Figura 9. Desdobramento das interações granulometrias (Fundo: $\varnothing<0,30 \mathrm{~mm} ; 50: \varnothing=0,30$ mm; 20: $\varnothing=0,84 \mathrm{~mm} ; 10: \varnothing=2 \mathrm{~mm}$ ) x períodos de incubação para teores de Ca e $\mathrm{Mg}$ do Nitossolo Vermelho eutrófico (NVe) com a aplicação de escória (a), silicato de cálcio (b), silicato de cálcio e magnésio (c), wollastonita $^{1}$ (d) e calcário dolomítico (e). * e ** significativos a $5 \%$ e $1 \%$ de probabilidade, respectivamente. ns- não significativo. ${ }^{1}$ possui apenas a fração granulométrica $<0,30 \mathrm{~mm}$.

Figura 10. . Desdobramento das interações granulometrias (Fundo: $\varnothing<0,30 \mathrm{~mm} ; 50: \varnothing=0,30$ $\mathrm{mm}$; 20: $\varnothing=0,84 \mathrm{~mm} ; 10: \varnothing=2 \mathrm{~mm}$ ) x períodos de incubação para valores de SB, CTC e V\% do Nitossolo Vermelho eutrófico (NVe) com a aplicação de escória (a), silicato de cálcio (b), silicato de cálcio e magnésio (c), wollastonita ${ }^{1}$ (d) e calcário dolomítico (e). * e ** significativos a $5 \%$ e $1 \%$ de probabilidade, respectivamente. ns- não significativo. ${ }^{1}$ possui apenas a fração granulométrica $<0,30 \mathrm{~mm}$. 62

Figura 11. Desdobramento das interações granulometrias (Fundo: $\varnothing<0,30 \mathrm{~mm} ; 50: \varnothing=0,30$ $\mathrm{mm} ; 20: \emptyset=0,84 \mathrm{~mm} ; 10: \varnothing=2 \mathrm{~mm}) \mathrm{x}$ períodos de incubação para valores de $\mathrm{pH}$ e $\mathrm{H}+\mathrm{Al}$ do 
Neossolo Quartzarênico (NQ) com a aplicação de escória (a), silicato de cálcio (b), silicato de cálcio e magnésio (c), wollastonita ${ }^{1}$ (d), calcário calcítico (e) e calcário dolomítico (f). * e ** significativos a $5 \%$ e $1 \%$ de probabilidade, respectivamente. ns- não significativo. ${ }^{1}$ possui apenas a fração granulométrica $<0,30 \mathrm{~mm}$. 72

Figura 12. Teores de Ca e Mg do Neossolo Quartzarênico (NQ) em função dos períodos de incubação de escória (a), silicato de cálcio (b) e calcário calcítico (c). * e ** significativos a $5 \%$ e $1 \%$ de probabilidade.

Figura 13. Desdobramento das interações granulometrias (Fundo: $\varnothing<0,30 \mathrm{~mm} ; 50: \varnothing=0,30$ mm; 20: $\varnothing=0,84 \mathrm{~mm} ; 10: \varnothing=2 \mathrm{~mm})$ x períodos de incubação para teores de Ca e $\mathrm{Mg}$ do Neossolo Quartzarênico (NQ) com a aplicação de silicato de cálcio e magnésio (a), wollastonita $^{1}$ (b), silicato de cálcio (c) e calcário dolomítico (d). * e ** significativos a 5\% e $1 \%$ de probabilidade, respectivamente. ns- não significativo. ${ }^{1}$ possui apenas a fração granulométrica $<0,30 \mathrm{~mm}$.

Figura 14. Desdobramento das interações granulometrias (Fundo: $\varnothing<0,30 \mathrm{~mm} ; 50: \varnothing=0,30$ $\mathrm{mm}$; 20: $\varnothing=0,84 \mathrm{~mm}$; 10: $\varnothing=2 \mathrm{~mm}$ ) x períodos de incubação para valores de SB, CTC e V\% do Neossolo Quartzarênico (NQ) com a aplicação de calcário dolomítico (a), silicato de cálcio (b), silicato de cálcio e magnésio (c) escória (d), e wollastonita $^{1}$ (e). * e ** significativos a $5 \%$ e $1 \%$ de probabilidade, respectivamente. ns- não significativo. ${ }^{1}$ possui apenas a fração granulométrica $<0,30 \mathrm{~mm}$.

Figura 15. Valores de SB e CTC do Neossolo Quartzarênico (NQ) em função de períodos de incubação de escória (a), silicato de cálcio (b), silicato de cálcio e magnésio (c) e calcário calcítico $(\mathrm{d}) . * \mathrm{e}^{* *}$ significativos a $5 \%$ e $1 \%$ de probabilidade. 


\section{RESUMO}

A eficiência dos corretivos de acidez do solo, e, sua qualidade depende da taxa de reatividade (RE), e do poder de neutralização $(\mathrm{PN})$, sendo esta eficiência indicada pelo poder relativo de neutralização total (PRNT). Para os silicatos existem poucos estudos que estabeleça taxas de reatividade para suas frações granulométricas e, portanto, utilizam-se as mesmas taxas de reatividade do calcário. Foram desenvolvidos três experimentos no período de julho/2008 a outubro/2009 em casa de vegetação na Faculdade de Ciências Agronômicas/UNESP - Botucatu-SP, com o objetivo de comparar valores de reatividade das frações granulométricas para materiais silicatados em três solos de diferentes classes texturais cultivados com plantas de alfafa. Utilizou-se seis materiais corretivos: escória, silicato de cálcio, silicato de cálcio e magnésio, wollastonita, calcário dolomítico e calcário calcítico os quais no experimento 1 e 2 foram separados em quatro frações granulométricas, peneiras: $n^{\circ}$ $10(\varnothing=2 \mathrm{~mm}), \mathrm{n}^{\mathrm{o}} 20(\varnothing=0,84 \mathrm{~mm}), \mathrm{n}^{\circ} 50(\varnothing=0,30 \mathrm{~mm})$ e fundo $(\varnothing<0,30 \mathrm{~mm})$, exceto a wollastonita que possui apenas a granulometria $<0,30 \mathrm{~mm}$. Os tratamentos foram aplicados em três solos: Latossolo Vermelho distrófico, Nitossolo Vermelho eutrófico e Neossolo Quartzarênico. No $1^{\circ}$ experimento aplicou-se quatro doses $\left(1,2,4\right.$ e $\left.8 \mathrm{t} \mathrm{ha}^{-1}\right)$ afim de obter a curva de neutralização dos solos, para determinar a dose a ser aplicada de cada fração granulométrica para atingir o pH 5,5. O $2^{\circ}$ experimento constou da aplicação das doses ecomendadas no primeiro experimento e com o valor de pH obtido aos 90 dias de incubação calculou-se a eficiência relativa de reatividade para cada fração granulométrica, tomando-se 
como referência o pH obtido com a aplicação do calcário dolomítico na peneira fundo. Em seguida calculou-se a reatividade (RE) dos corretivos e o PRNT. No $3^{\circ}$ experimento calculouse a dose para elevar a saturação por bases dos solos a $80 \%$, aplicando o PRNT obtido em laboratório e o PRNT obtido pelo experimento. Os tratamentos foram incubados por 30 dias e semeou a alfafa, na qual se realizou dois cortes. As taxas de eficiência relativa para a reatividade dos silicatos foram superiores às determinadas pela legislação brasileira, sendo, as frações granulométricas dos silicatos de cálcio e de cálcio e magnésio as que apresentaram os maiores valores de eficiência relativa. Para o calcário e a wollastonita os valores foram próximos aos vigentes pela legislação brasileira. A reatividade dos corretivos variou com a classe do solo. As doses de corretivos de acidez aplicadas não proporcionaram a correção da acidez do solo desejada para o desenvolvimento das plantas de alfafa. 
RELATIVE EFFICIENCY EVALUATION OF SILICATE REACTIVITY. Botucatu, 2010. Dissertação (Mestrado em Agronomia/Agricultura) - Faculdade de Ciências Agronômicas, Universidade Estadual Paulista.

Author: Angélica Cristina Fernandes Deus

Adviser: Leonardo Theodoro Büll

\section{SUMMARY}

The efficiency and quality of materials for soil acidity correction are based on the reactivity rate (RR) and neutralization power (NP), and it is indicated by the effective calcium carbonate (ECC). Considering that there are few studies establishing reactivity rates of silicate particle-size fractions, lime values are used as reference. Three experiments were carried in the period July/2008 to October/2009 out in greenhouse in College of Agricultural Sciences, UNESP, Botucatu - SP, aiming to compare reactivity rates of silicate particle-size fractions in three soils with distinct textures cultivated with alfalfa plants. Slag, calcium silicate, calcium+magnesium silicate, wollastonite, dolomitic and calcitic lime were the materials evaluated. The first and second experiments consisted of four particlesize fractions obtained from each material, separated by the sieves no. 10 ( $\varnothing=2 \mathrm{~mm})$, no. 20 $(\varnothing=0.84 \mathrm{~mm})$, no. $50(\varnothing=0.30 \mathrm{~mm})$ and bottom $(\varnothing<0.30 \mathrm{~mm})$, except that the wollastonite has the particle-size fraction $<0,30 \mathrm{~mm}$. Treatments were applied in three soils: Oxisol, Hapludox and Quartzipsamment. In the first study, four doses were applied (1, 2, 4 and $8 \mathrm{t}$ ha $^{-}$ ${ }^{1}$ ) to obtain soil neutralization curve and thus determine which one was to be applied for each particle-size fraction to reach $\mathrm{pH}$ 5.5. The second study consisted of the application of the recommended doses from the first experiment. Then, with the $\mathrm{pH}$ values obtained 90 days after incubation, the relative efficiency of reactivity was calculated for each particle-size fraction based on the $\mathrm{pH}$ of dolomitic lime from the last sieve. Afterwards, RR and ECC were calculated. In the third study, the doses to increase soil base saturation up to $80 \%$ were calculated based on both the PRNT reported in the laboratory and in the experiment. Treatments were incubated for 30 days and then alfalfa was sown. During crop development, two cuttings were carried out. The relative efficiency rates of silicate reactivity were higher than the ones established by Brazilian legislation. The particle-size fractions of both calcium 
silicate and calcium+magnesium silicate showed higher relative efficiency. Lime showed similar values to the current ones established by Brazilian legislation. Soil type significantly affected the reactivity of the materials. The doses of liming materials applied did not provide the correction of soil acidity for alfafa cropping. 


\section{INTRODUÇÃO}

A prática da correção da acidez do solo é imprescindível para a obtenção de maiores produtividades agrícolas no Brasil, uma vez que mais de $70 \%$ de seus solos são ácidos (QUAGGIO, 2000). O calcário é o corretivo mais utilizado na neutralização da acidez do solo, entretanto, está ocorrendo aumento de pesquisas no uso agrícola de corretivos a base de silicatos.

As melhorias nas propriedades químicas do solo pela utilização de materiais silicatados, à semelhança do que ocorre com o calcário, decorrem da ação neutralizante do $\mathrm{SiO}_{3}{ }^{2-}$, que reage com a água e libera íons $\mathrm{OH}^{-}$, que neutralizam o $\mathrm{H}^{+}$e o $\mathrm{Al}^{3+}$ fitotóxico e, consequentemente, ocorre elevação do pH e dos teores de Ca e $\mathrm{Mg}$, e V\%, além da diminuição da concentração da acidez potencial (PRADO et al., 2001).

A eficiência de corretivos da acidez do solo e, consequentemente, a qualidade deles depende fundamentalmente da eficiência relativa das partículas, por classe de granulometria denominado de reatividade (RE), e do poder de neutralização (PN), sendo esta eficiência indicada pelo poder relativo de neutralização total (PRNT). Além destas características outras podem influenciar a eficiência dos corretivos como a solubilidade do material, tipo de solo e condições climáticas (PANDOLFO e TEDESCO, 1996). No caso dos silicatos a experimentação agrícola brasileira dispõe de pouca informação a respeito de sua qualidade. 
Entre os materiais silicatatos tem-se a escória, que é subproduto da fabricação do ferro e do aço. Pesquisas realizadas com este material mostraram ação neutralizante na acidez do solo semelhante à do calcário (WUTKE e GARGANTINI, 1962), entretanto, a aplicação de escória de siderurgia em um Latossolo Vermelho e em um Neossolo Quartzarênico, mostrou que, a eficiência da escória baseado no poder de neutralização adotado para o calcário não apresentou comportamento satisfatório para estimar a necessidade de produto para a correção da acidez destes solos, sugerindo mais estudos (PRADO e FERNANDES 2000).

Esta diferença também pode ser em decorrência da determinação das taxas de reatividade das frações granulométricas que seguem a mesma metodologia oficial adotada para o calcário (BRASIL 1986). Ao aplicar para os silicatos as taxas de reatividade que são estabelecidas para o calcário, podem-se obter erros, visto que os silicatos apresentam composição e comportamento distinto do calcário (PRADO et al., 2001).

Apesar de saber que o incorreto cálculo da reatividade dos silicatos, pode comprometer a sua eficiência, ainda utiliza-se para estes materiais os mesmos valores de reatividade das frações granulométricas empregados para o calcário. Há, portanto, a necessidade de padronizar novos valores de eficiência relativa de reatividade para os silicatos, com a finalidade de que se possa aplicar quantidades corretas e obter maiores eficiências desses corretivos na neutralização da acidez do solo.

Tendo em vista a carência de trabalhos visando à reatividade das frações granulométricas de silicatos e o comportamento diferencial em função dos tipos de solo, o trabalho foi realizado com o objetivo de comparar valores de reatividade das frações granulométricas para materiais silicatados em três solos de diferentes classes texturais cultivados com plantas de alfafa. 


\section{REVISÃO DE LITERATURA}

\subsection{Acidez do solo}

A acidez é um dos principais atributos químicos relacionados com o desenvolvimento das plantas, pois determina a existência ou não de elementos fitotóxicos e afeta a disponibilidade de quase todos nutrientes no solo. Existem dois tipos de acidez no solo: a ativa e a potencial. A acidez ativa é representada pela atividade de $\mathrm{H}^{+}$na solução. É ela que afeta quase a totalidade das reações que ocorrem no solo relacionados com a disponibilidade de nutrientes. A acidez ativa é representada pelo valor de $\mathrm{pH}$, o qual expressa a atividade dos íons hidrogênio na solução do solo, e está relacionado com a disponibilidade, deficiência ou toxidez dos elementos (ERNANI, 2008).

A acidez potencial é constituída pelo somatório de todas as fontes de $\mathrm{H}^{+}$que existem nos componentes sólidos do solo, principalmente o alumínio trocável e os grupos funcionais orgânicos e inorgânicos. Esta acidez é, portanto proporcional aos teores de alumínio, de argila e de matéria orgânica existentes no solo, e determina a necessidade de corretivo a ser aplicada. A acidez potencial somente afeta a atividade de $\mathrm{H}^{+}$na solução do solo quando o $\mathrm{pH}$ for alterado e, portanto, ela é tamponante da acidez ativa. A acidez potencial é representada analiticamente pelos valores de $\mathrm{H}+\mathrm{Al}$ ou de pH-SMP (ERNANI, 2008). 
A acidificação do solo consiste na remoção dos cátions básicos $(\mathrm{Ca}$, $\mathrm{Mg}, \mathrm{K}, \mathrm{Na}$ ) do complexo de troca catiônica. No Brasil os solos agrícolas, na maioria, são ácidos. Em condições de acidez elevada podem ocorrer teores de alumínio e manganês em níveis tóxicos Raij (1983), associado às deficiências de Ca, Mg, K e P, e como conseqüência, tem-se a baixa produtividade das plantas cultivadas, pois, a presença de alumínio inibe o crescimento radicular e interfere no processo de absorção das plantas (KAMINSKI e RHEINHEIMER, 2000; PAVAN e OLIVEIRA, 2000).

Os solos podem ser naturalmente ácidos em razão da pobreza do material de origem em cátions básicos, ou por condições de pedogênese ou de formação de solo que favorecem a remoção de elementos químicos do solo Raij (1983), pois, durante a formação do solo a partir da rocha, ocorre ação dos agentes do intemperismo sobre os minerais de argila que levam a liberação de Al, Fe e Mn, dentre outros, para a solução do solo, ao serem hidrolisados esses cátions dissociam íons $\mathrm{H}^{+}$, com reflexos na acidificação do solo (ERNANI, 2008). Além disso, o processo de acidificação do solo pode ser acelerado ou intensificado em sistemas agrícolas mediante processos de manejo de solos que levam à perda de bases e, portanto, promovem a acidificação (QUAGGIO, 2000).

Desta forma, a calagem é uma prática rotineira e indispensável para neutralizar a acidez e aumentar a produtividade agrícola, devido seus efeitos na correção do solo, com reflexos na maior eficiência das raízes em absorção de água e nutrientes, com diminuição nas perdas de bases por lixiviação, diminuição na fixação do fósforo, precipitação do alumínio, manganês e ferro além de fornecer cálcio e magnésio (VITTI et al.,1996).

Existem vários métodos de determinação da necessidade de calagem em solos. Em uso no Brasil existem principalmente três, além de algumas variações locais para os mesmos métodos (RAIJ, 1983).

1) Neutralização do alumínio

Baseado na neutralização do alumínio, e aplica-se a fórmula:

Necessidade de calcário em $\mathrm{t} / \mathrm{ha}(\mathrm{NC})=$ meq $\mathrm{Al} / 100 \mathrm{~cm}^{3} \times \mathrm{f}$ 
Onde:

$\mathrm{F}=1,5$ para culturas tolerantes a acidez (ex. gramíneas)

$\mathrm{F}=2,0$ para culturas não tolerantes a acidez (ex. leguminosas)

Deve-se considerar que a dose de calcário calculada por esse método é insuficiente para elevar o $\mathrm{pH}$ do solo de modo sensível, geralmente +/- $\mathrm{pH}$ 5,5.

2) Solução tampão SMP

Utilizado nos Estados do Rio Grande do Sul e Santa Catarina. O método consiste em agitar uma quantidade de solo com um volume da solução tampão. Através do $\mathrm{pH}$ da suspensão, representado por pH SMP, é consultada a recomendação de calcário (PRNT 100\%) para elevar o pH do solo a 5,5 , 6,0 ou 6,5 (pH em água).

As doses de calcário, obtidas através dos critérios descritos nos métodos 1 e 2, referem-se a calcário com PRNT - 100\%. Para calcários com valores de PRNT diferentes de $100 \%$, é necessário corrigir a dose de acordo com a fórmula:

Dose calculada $\mathrm{x}$ PRNT do calcário

3) Saturação por bases

Utilizado nos Estados de São Paulo e Paraná. Baseia-se na relação existente entre $\mathrm{pH}$ e saturação por bases. $\mathrm{Na}$ fórmula são considerados variáveis referentes à solo, corretivo e cultura específica.

$$
\mathrm{NC}\left(\mathrm{t} \mathrm{ha}^{-1}\right)=\frac{\mathrm{T}(\mathrm{V} 2-\mathrm{V} 1) \times \mathrm{F}}{100}
$$

Onde:

$\mathrm{NC}=$ necessidade de calcário

$\mathrm{T}=$ capacidade de troca de cátions a pH 7,0 = meq $(\mathrm{K}+\mathrm{Ca}+\mathrm{Mg}+\mathrm{H}+\mathrm{Al}) / 100 \mathrm{~cm}^{3}$

V2 = saturação por bases desejada para a cultura a ser implantada 
$\mathrm{V} 1=$ saturação por bases atual do solo $=\frac{\mathrm{S}}{\mathrm{T}} \times 100$

$\mathrm{S}=$ soma de bases $=$ meq $(\mathrm{K}+\mathrm{Ca}+\mathrm{Mg}) / 100 \mathrm{~cm}^{3}$

$\mathrm{F}=\underline{100}$

PRNT

É importante salientar que os solos diferem nas necessidades de corretivo para proporcionar uma mesma mudança de $\mathrm{pH}$. Diz-se que os solos diferem em poder tampão. Essas diferenças são devidas à capacidade de troca, que é maior em solos mais ricos em matéria orgânica e/ou com teores mais elevados de argila e, ainda, quando a argila apresenta maior atividade de superfície (RAIJ, 1983). Por esta razão, os métodos de cálculo da necessidade de calagem que consideram o poder tampão do solo, como a CTC, são os mais indicados.

\subsection{Corretivos da acidez do solo}

Os corretivos da acidez dos solos são aqueles que contém como "constituintes neutralizantes" ou "princípios ativos": carbonatos, óxidos, hidróxidos ou silicatos de cálcio e ou de magnésio, isto é, compostos de cálcio e ou de magnésio de caráter alcalino Alcarde (1986), capazes de neutralizar a acidez dos solos e, ainda, levar nutrientes vegetais até eles, principalmente Ca e Mg (ALCARDE, 1992).

A acidez de um solo se deve à presença de íons $\mathrm{H}^{+}$livres, gerados por componentes ácidos presentes no solo. A neutralização da acidez consiste em neutralizar os prótons, o que é feito pelo ânion $\mathrm{OH}^{-}$. Portanto, os corretivos de acidez devem ter componetes básicos para gerar $\mathrm{OH}^{-}$e promover a neutralização (ALCARDE e RODELLA 2003).

O material corretivo natural comumente utilizado no Brasil é a rocha calcária moída, existente com relativa freqüência e abundância. Em vista disso, são os materiais mais utilizados para corrigir a acidez dos solos. Seus constituintes neutralizante são o $\mathrm{CaCO}_{3}$ e o $\mathrm{MgCO}_{3}$. De acordo com o teor de $\mathrm{MgO}_{3}$, os calcários são classificados em: 
calcítico, com teor mediano de $\mathrm{MgO}_{3}$ entre 10 e $25 \%$; e dolomítico, com teor de $\mathrm{MgCO}_{3}$ acima de 25\% (ALCARDE e RODELLA, 2003).

Além do calcário, diversos outros materiais também podem ser usados como corretivos. Dentre eles, os materiais silicatos cujo componente neutralizante é o silicato de cálcio e/ou de magnésio.

Uma das fontes mais abundantes e de baixo custo dos silicatos no Brasil é a escória de siderurgia, subproduto das indústrias do ferro e do aço. As escórias possuem alta concentração de $\mathrm{Ca}$ e $\mathrm{Mg}$, e desta forma também podem ser usadas na correção da acidez do solo, constituindo uma alternativa para o aproveitamento de parte desses subprodutos acumulados pelas indústrias (PRADO et al., 2001).

Entre os materiais que apresentam silicatos, existe também a wollastonita, provinda de uma rocha, com extração semelhante ao calcário, no entanto, não é explorada no Brasil e sua aquisição depende de importação (PRADO e FERNANDES, 2001). A wollastonita é o silicato de cálcio considerado padrão internacional, e dessa forma, muito empregado em experimentação (KORNDORFER et al., 2003).

O calcário, quando misturado ao solo e na presença de água, dissolvese e os carbonatos dissociam-se de acordo com a seguinte reação (ALCARDE e RODELLA, 2003).

$$
\begin{aligned}
& \mathrm{CaCO}_{3} \quad \stackrel{\mathrm{H}_{2} \mathrm{O}}{\longrightarrow} \quad \mathrm{Ca}^{2+}+\mathrm{CO}_{3}^{2-} \\
& \underline{\mathrm{MgCO}_{3}} \quad \stackrel{\text { solo }}{\mathrm{Mg}^{2+}+\mathrm{CO}^{2-}} \\
& \text { Calcário solução do solo } \\
& \mathrm{CO}_{3}{ }^{2-}+\mathrm{H}_{2} \mathrm{O}_{\text {(solo) }} \leftrightarrow \mathrm{HCO}_{3}^{-}+\mathrm{OH}^{-} \quad\left(\mathrm{Kb}_{1}=2,2 \times 10^{-4}\right) \\
& \mathrm{HCO}_{3}{ }^{-}+\mathrm{H}_{2} \mathrm{O}_{\text {(solo })} \longleftrightarrow \mathrm{H}_{2} \mathrm{O}+\mathrm{CO}_{2} \uparrow+\mathrm{OH}^{-} \quad\left(\mathrm{Kb}_{2}=2,4 \times 10^{-8}\right) \\
& \mathrm{OH}^{-}+\mathrm{H}^{+} \text {(solução do solo) } \longrightarrow \mathrm{H}_{2} \mathrm{O}
\end{aligned}
$$

$\mathrm{O}$ valor da constante de ionização $\left(\mathrm{Kb}_{1}\right)$ mostra que o $\mathrm{CO}_{3}{ }^{2-}$ é uma base fraca, isto é, a reação de formação de $\mathrm{OH}^{-}$é relativamente lenta e parcial. 
Os íons $\mathrm{Ca}^{2+}$ e $\mathrm{Mg}^{2+}$ deslocam o íon $\mathrm{Al}^{3+}$ adsorvido às partículas coloidais do solo para a solução de equilíbrio. Enquanto isso, o pH do meio aumenta e, os íons $\mathrm{HCO}_{3}{ }^{-}$, provocam a dissociação dos íons $\mathrm{H}^{+}$, formando acido carbônico que é a mistura de água e gás carbônico (QUAGGIO, 2000).

Com a elevação do $\mathrm{pH}$, os íons $\mathrm{Al}^{3+}$ hidratados sofrem hidrólise. Os íons $\mathrm{H}^{+}$, provenientes da hidrólise do $\mathrm{Al}^{3+}$ são neutralizados por hidroxilas oriundas da dissolução do calcário (QUAGGIO, 2000).

No caso dos silicatos a acidez do solo é neutralizada por meio da sua base $\mathrm{SiO}_{3}{ }^{2-}$ que reage com a água e libera íons $\mathrm{OH}^{-}$, conforme as equações (ALCARDE e RODELLA, 2003).

$$
\begin{aligned}
& \begin{array}{lll}
\mathrm{CaSiO}_{3} & \stackrel{\mathrm{H}_{2} \mathrm{O}}{\longrightarrow} & \mathrm{Ca}^{2+}+\mathrm{SiO}^{2-}{ }_{3} \\
\underset{\text { Escória }}{\mathrm{MgSiO}_{3}} & \text { solo } & \frac{\mathrm{Mg}^{2+}+\mathrm{SiO}^{2-}}{\text { solução do solo }}
\end{array} \\
& \mathrm{SiO}_{3}{ }^{2-}+\mathrm{H}_{2} \mathrm{O}_{\text {(solo })} \longleftrightarrow \mathrm{HSiO}_{3}{ }^{-}+\mathrm{OH}^{-} \quad\left(\mathrm{Kb}_{1}=1,6 \times 10^{-3}\right) \\
& \mathrm{HSiO}_{3}{ }^{-}+\mathrm{H}_{2} \mathrm{O}_{\text {(solo })} \longleftrightarrow \mathrm{H}_{2} \mathrm{SiO}_{3}+\mathrm{OH}^{-} \quad\left(\mathrm{Kb}_{2}=3,1 \times 10^{-5}\right) \\
& \mathrm{OH}^{-}+\mathrm{H}^{+} \text {(solução do solo) } \longrightarrow \mathrm{H}_{2} \mathrm{O}
\end{aligned}
$$

Essas equações mostram que a ação neutralizante da escória é muito semelhante á do calcário, neste caso a base $\mathrm{SiO}_{3}{ }^{2-}$ também é fraca $\left(\mathrm{Kb}_{1}=1,6 \times 10^{-3}\right)$, mas é mais forte que a base $\mathrm{CO}_{3}{ }^{2-}\left(\mathrm{Kb}_{1}=2,2 \times 10^{-4}\right)$.

Os $\mathrm{OH}^{-}$neutralizam o $\mathrm{H}^{+}$e o $\mathrm{Al}^{3+}$ fitotóxico e, ocorre diminuição da concentração da acidez potencial (PRADO et al., 2001).

A eficiência de correção dos silicatos, á semelhança do calcário, varia em função da granulometria, reatividade, dose, tipo de solo e o tempo de contato do material com o solo.

É importante lembrar que as partículas de corretivos, provenientes de materiais de silicato, apresentam maior solubilidade em relação ao calcário Alcarde (1992), a 
qual é proporcionada em razão dessas partículas apresentarem maior quantidade de poros, o que lhe confere maior superfície específica, atribuindo assim maior velocidade de reação para sua dissociação.

O ânion acompanhante $\mathrm{SiO}_{3}$, confere solubilidade de 6,78 vezes superior ao calcário, onde o $\mathrm{CaCO}_{3}=0,014 \mathrm{~g} \mathrm{~L}^{-1}$ e $\mathrm{CaSiO}_{3}=0,095 \mathrm{~g} \mathrm{~L}^{-1}$ (ALCARDE e RODELLA, 2003). A maior solubilidade do silicato confere a vantagem de reduzir a acidez do solo mais rapidamente que o calcário, permitindo com que os produtos da reação de dissociação apresentem maior mobilidade no solo Quaggio (2000), inclusive em profundidade (CORRÊA et al., 2007).

Outra vantagem de se utilizar silicatos em relação à carbonatos, é que o silício $\left(\mathrm{SiO}_{3}{ }^{2-}\right)$ pode saturar os sítios de adsorção de $\mathrm{P}$ nos sesquióxidos de $\mathrm{Fe}$ e $\mathrm{Al}$ nos solos, tornando esse elemento mais disponível às plantas (PRADO et al., 2001).

O uso agrícola de silicatos como corretivo da acidez do solo vem sendo difundido no Brasil desde 1962 por Wutke e Gargantini que avaliaram duas escórias de siderurgia. As escórias mostraram-se viáveis para seu uso na neutralização da acidez, desde que com granulometria mais fina do que a empregada no experimento.

Piau (1991) avaliou o comportamento de diversas escórias brasileiras, comparativamente ao calcário. $\mathrm{O}$ autor incubou estes corretivos em um Latossolo Vermelho Amarelo, durante noventa dias, utilizando fração granulométrica que passou na peneira de $0,30 \mathrm{~mm}$ e ficou retido na peneira de $0,250 \mathrm{~mm}$, com a aplicação de uma e duas vezes a necessidade de calagem. Os resultados permitiram concluir que a aplicação de escória nessa fração granulométrica age eficientemente na correção da acidez do solo.

Em condições de campo o trabalho de Corrêa et al. (2007) demonstrou que os silicatos corrigem a acidez dos solos com maior eficiência que o calcário. Esses resultados, em alguns casos, são proporcionados em razão dos silicatos apresentarem menores valores de PRNT em relação ao calcário, permitindo que o método de necessidade de calagem preconize maiores quantidades para os materiais silicatados a fim de elevar a saturação por bases ao nível adequado para a cultura de interesse.

Nota-se pelas pesquisas realizadas a importância da granulometria dos silicatos; quanto mais fina maior a superfície especifica do material, e isto permite melhor reação no solo. Entretanto, para estes materiais existem poucos estudos que estabeleçam taxas 
de reatividade para suas frações granulométricas e, portanto, utilizam-se as mesmas taxas de reatividade do calcário.

A viabilidade dos silicatos como corretivo de acidez do solo foi verificado para diversas culturas, como na alface por Amaral et al. (1994), na produção de mudas de goiabeira por Prado et al. (2003), na cultura de cana de açúcar por Prado e Fernandes (2001) entre outras. Assim, a capacidade de correção da acidez do solo por materiais a base de silicatos não é mais questionada, o que se deixa a desejar é a avaliação de sua qualidade. No que se refere à qualidade em função da reatividade, o trabalho de Prado et al. (2004) avaliou a reatividade de frações granulométricas dos silicatos, entretanto, utilizou-se apenas um tipo de solo, é importante considerar que a reatividade depende do tipo de solo.

\subsection{Qualidade dos corretivos de acidez do solo}

As características relacionadas com a qualidade dos corretivos são: natureza química dos constituintes; poder de neutralização; teores de cálcio e magnésio; solubilidade; granulometria; efeito residual e poder relativo de neutralização total.

Dentre essas características apenas duas tem sido considerada na avaliação da qualidade dos corretivos: o poder de neutralização (PN) e a granulometria (RE), e com estas obtém-se o poder de neutralização total (PRNT).

\subsubsection{Granulometria (RE)}

A reatividade de um corretivo consiste em sua velocidade de ação no solo, ou seja, a rapidez com que a acidez é corrigida. Apesar da reatividade depender de uma série de fatores, como natureza química dos neutralizantes, poder neutralizante, condições de clima e solo, dose, maneira de aplicação e grau de homogeneização a granulometria é um dos fatores fundamentais: a relação entre a reatividade e a granulometria é direta, isto é, quanto maior o grau de finura maior a reatividade. (ALCARDE, 1986).

A avaliação da granulometria dos corretivos é feita através do peneiramento mecânico da amostra, utilizando peneiras com aberturas de malhas especificadas 
$\operatorname{ABNT~}^{\circ} 10(\varnothing=2 \mathrm{~mm})$, ABNT $^{\circ} 20(\varnothing=0,84 \mathrm{~mm})$, ABNT $^{\circ} 50(\varnothing=0,30 \mathrm{~mm})$ e fundo (Ø<0,30 mm), determinadas pela legislação brasileira (BRASIL, 1986).

De acordo com a legislação brasileira, o calcário deve apresentar características mínimas do poder de neutralização e reatividade para ser comercializado, ao passo que, para a escória de siderurgia, a exigência mínima está restrita apenas ao poder de neutralização (PRADO et al., 2001). Entretanto, para que o material tenha alta eficiência como corretivo de acidez do solo, é necessário que tenha boa reatividade.

Segundo a legislação dos calcários, a exigência granulométrica é de que os corretivos devam passar $95 \%$ na peneira ABNT n ${ }^{\circ} 10$, com tolerância de $5 \%$ e, no mínimo $50 \%$ na peneira $\mathrm{ABNT}^{\circ} 50$.

Os valores adotados para eficiência relativa das frações granulométricas dos corretivos de acidez foram determinados para materiais à base de calcário, sendo esses valores regulamentados, atualmente, pela portaria do Ministério da Agricultura $\mathrm{n}^{\circ} 31$, de 1986 (BRASIL 1986), e apresentam valores de 20\% de reatividade para partículas entre 2,00 e 0,84 mm (peneira ABNT 10 e 20), 60\% para partículas entre 0,84 e $0,30 \mathrm{~mm}$ (peneiras 20 e 50) e de $100 \%$ para partículas inferiores a $0,30 \mathrm{~mm}$, lembrando que esses valores representam a porcentagem do corretivo que reagirá no solo dentro de um período de três meses. Desta forma, a partir dos resultados da composição granulométrica calcula-se a reatividade (RE) do corretivo pela expressão:

$$
\% \mathrm{RE}=\% \mathrm{~F}_{10} \times 0,0+\% \mathrm{~F}_{10-20} \times 0,2+\% \mathrm{~F}_{20-50} \times 0,6+\% \mathrm{~F}_{50} \times 1
$$

Sendo:

$\% \mathrm{~F}_{10}=$ percentual de produto que fica retido na peneira 10

$\% \mathrm{~F}_{10-20}=$ percentual de produto que passa pela peneira $\mathrm{n}^{\circ} 10$ e fica retido na peneira $\mathrm{n}^{\circ} 20$;

$\% \mathrm{~F}_{20-50}=$ percentual de produto que passa pela peneira $\mathrm{n}^{\circ} 20$ e fica retido na peneira $\mathrm{n}^{\circ} 50$;

$\% \mathrm{~F}_{50}=$ percentual de produto que passa pela peneira $\mathrm{n}^{\circ} 50$

A escória de siderurgia é classificada como corretivo de acidez do solo, e aplica-se a escoria a mesma legislação do calcário para sua comercialização, no entanto os valores de eficiência relativa que foram determinados para materiais à base de calcário, 
ficam vulneráveis, quando se aplica esses mesmos critérios de reatividade para materiais com base em silicatos, visto que são materiais com composição distinta. Lembrando que as partículas de corretivos, provenientes de materiais de silicato, apresentam maior solubilidade em relação ao calcário (ALCARDE, 1992).

Como a taxa de reatividade considera apenas o tamanho das partículas, onde partículas menores apresentam maior superfície específica e, consequentemente maior contato entre o corretivo e solo, aumentando assim a velocidade de dissolução dessa partícula e, portanto, sua reatividade, surge, uma incógnita para materiais que apresentam porosidade, como os silicatos. Pode-se inferir que a presença da maior porosidade nas partículas de silicato confere o mesmo efeito, em razão dos poros aumentarem a superfície específica e considerando que no solo a água é um importante componente, cuja a presença de sais nela dissolvidos a caracterizam como a solução do solo, a qual é atribuída algumas das principais funções de intemperismo químico como hidrólise, dissolução e hidratação Oliveira (2005), ela pode entrar no interior dessas partículas conferindo maior velocidade de dissolução.

Devido a maior quantidade de poros nos silicatos, conferindo maior velocidade de dissolução de sua partícula, os valores de eficiência relativa utilizados no calcário tornam-se inadequados para avaliar a eficiência relativa de reatividade dos silicatos, conduzindo a erros, como subestimar a capacidade de neutralização hidrogeniônica e, conseqüentemente, superestimar a quantidade a ser utilizada para correção da acidez do solo.

\subsubsection{Poder de neutralização (PN)}

A avaliação do teor de neutralizantes dos corretivos é feita através das determinações químicas do poder de neutralização (PN) e dos teores de cálcio e magnésio.

Para qualquer natureza de corretivo, considera-se o constituinte neutralizante como sendo o $\mathrm{CaCO}_{3}$ e o resultado expresso em equivalente em carbonato de cálcio - $\mathrm{E}_{\mathrm{CaCO} 3}$ (BRASIL 1986).

O poder de neutralização indica a capacidade potencial do corretivo em neutralizar a acidez dos solos (ALCARDE, 1986). Em sua determinação utiliza-se como padrão o $\mathrm{CaCO}_{3}$ puro que, convencionalmente recebe o valor de 100 , e sua determinação pode ser calculada ou determinada. 
O PN é calculado em função dos teores de óxido de cálcio e de magnésio, isto é, \% $\mathrm{CaO} \times 1,79+\% \mathrm{MgO}$ x 2,48=\% $\mathrm{E}_{\mathrm{CaCO} 3}$, (ALCARDE, 1986). O PN calculado pode incorrer em erros, pois, estima-se que os teores de $\mathrm{Ca}$ e $\mathrm{Mg}$ determinados estejam ligados a uma base química eficiente como carbonato, óxido ou silicato.

O PN determinado consiste em fazer com que uma amostra de corretivo reaja com uma quantidade conhecida e em excesso de ácido clorídrico relativamente diluído (0,5N) (BRASIL, 1986). Dessa forma, é dada oportunidade ao corretivo de exercer toda a sua capacidade de neutralizar o ácido. Posteriormente, determina-se o excesso de ácido e, por diferença, calcula-se a quantidade de ácido neutralizada pelo corretivo, a capacidade obtida é expressa em teor de neutralizante equivalente ao carbonato de cálcio $\left(\% \mathrm{E}_{\mathrm{CaCO} 3}\right)$ presente na amostra independente da natureza química do corretivo.

Comparando o valor de PN calculado com o determinado, têm-se produtos em que os resultados são semelhantes, enquanto em outros o valor determinado é inferior ao calculado. Essa diferença ocorre devido às formas diferentes de ataque da amostra nas determinações do $\mathrm{PN}$ e do $\mathrm{CaO}$ e $\mathrm{MgO}$. No primeiro o ataque é suave ou brando, pois utiliza solução relativamente diluída $(0,5 \mathrm{~N})$ de $\mathrm{HCl}$ e no segundo o ataque é enérgico, utilizando solução concentrada $(12 \mathrm{~N})$ de $\mathrm{HCl}$. A grandeza da diferença depende da natureza e da granulometria do material (ALCARDE, 1986).

Deve-se notar que a determinação do PN indica apenas que o produto é alcalino ou básico, e a partir daí apenas supõe-se que o seu constituinte seja o $\mathrm{CaCO}_{3}$, e não permite caracterizar o produto, isto é, se é carbonato, óxido, hidróxido ou silicato, assim como também não possibilita caracterizar se o produto é corretivo de acidez dos solos, ou seja, se a base está associada ao cálcio ou ao magnésio (ALCARDE, 1986).

Para ser considerado corretivo agrícola exige-se que os neutralizantes estejam associados ao cálcio e ou magnésio, devido a estes se constituírem em macronutrientes vegetais Alcarde (1986), é por isso que o cálcio e o magnésio também devem ser determinados. Atualmente é determinado no extrato do PN e fundamenta-se na solubilização do cálcio e magnésio contido no corretivo em meio ácido e sua determinação por volumetria com EDTA (ALCARDE, 2009).

Entretanto nem todo o cálcio e magnésio dos calcários devem estar associados às bases químicas, mas também a outras bases inexpressivas, assim como os 
constituintes neutralizantes podem estar aprisionados em cristais de outros componentes como sílica, que só são atingidos por um ataque enérgico da amostra (ALCARDE e RODELLA, 1996).

A legislação brasileira Brasil (1986), exige que a escória de siderurgia apresente no mínino $60 \%$ de poder de neutralização, e a soma dos óxidos de cálcio e de magnésio deve ser superior a $30 \%$. Para o calcário, o PN mínimo é de $67 \%$ e a soma de óxidos de cálcio e de magnésio deve ser superior a $38 \%$.

No entanto, quando se utiliza a mesma metodologia do calcário para a escória, os resultados podem sofrer alterações, pois se considera que, do ponto de vista químico, a determinação do $\mathrm{PN}$ utilizando solução de $\mathrm{HCl} 0,5 \mathrm{~N}$, é branda, surgindo questionamentos com relação ao potencial de solubilização integral dos componentes neutralizantes da amostra, principalmente aqueles aprisionados em cristais com a sílica, que só seria atingido pelo ataque mais energético da amostra. Além disto, a presença de contaminantes como micronutrientes metálicos podem interferir nos resultados da determinação do PN (PIAU, 1995).

\subsubsection{Poder Relativo de Neutralização Total (PRNT)}

A ação de um corretivo depende fundamentalmente das características: poder de neutralização $(\mathrm{PN})$, e o grau de moagem, que é a reatividade (RE). Isoladas, elas não possibilitam adequada avaliação da ação do corretivo, por isso, foram associadas, dando origem ao PRNT, Poder Relativo de Neutralização Total, que indica a capacidade neutralizante dos corretivos (ALCARDE e RODELLA, 2003).

O PRNT considera a pureza química da rocha de origem, ou seja, o poder de neutralização (PN), e o grau de moagem, que é a reatividade (RE), ambos expressos em percentagem de equivalência ao $\mathrm{CaCO}_{3}$ puro (QUAGGIO, 2000). Assim, quanto maior a pureza química da rocha calcária e sua RE, maior será o PRNT e menor deverá ser o efeito residual do calcário aplicado no solo.

Recorda-se que a reatividade é o percentual da ação do corretivo num período de três meses devido à granulometria, ou seja, considerando um corretivo com $\mathrm{RE}=$ $80 \%$ e $\mathrm{PN}=97 \% \mathrm{ECaCO}_{3}$, o PRNT significa então que $80 \%$ (RE) do seu potencial de 
neutralização $(\mathrm{PN})$ será exercido em três meses. E o corretivo está assim dividido: 78 \% agirá em três meses e $19 \%$ agirá posteriormente. Portanto, o PRNT é a fração do seu PN que agirá em três meses (ALCARDE e RODELLA, 2003). Isto mostra a importância de se conhecer o PN dos corretivos; apenas o conhecimento do PRNT não permite a adequada avaliação.

O período de três meses é explicado pelo fato de as taxas de eficiência granulométrica atuais da legislação brasileira terem sido determinadas apenas durante três meses para o calculo da reatividade (ALCARDE, 1986). 


\section{MATERIAL E MÉTODOS}

Realizou-se três experimentos, os quais foram conduzidos em casa de vegetação no Departamento de Recursos Naturais - Área Ciência do Solo da Faculdade de Ciências Agronômicas, campus de Botucatu/UNESP no período de julho de 2008 a outubro de 2009.

\subsection{Solos}

Os solos utilizados foram: Latossolo Vermelho distrófico textura franco arenosa (LVd), Neossolo Quartzarênico (NQ) e Nitossolo Vermelho eutrófico (NVe) (EMBRAPA, 1999), os quais foram coletados na camada arável de $0-20 \mathrm{~cm}$ e peneirados em peneira de malha de $4 \mathrm{~mm}$.

Uma amostra de cada solo foi seca ao ar e peneirada em malha de 2 mm para a análise das características químicas e granulométricas. A análise química foi realizada no Laboratório de Fertilidade do Solo do Departamento de Recursos Naturais - Área Ciência do Solo da FCA/Unesp de Botucatu, seguindo a metodologia de Raij et al. (2001), enquanto a determinação granulométrica foi realizada pelo método da pipeta (EMBRAPA, 1997) no Laboratório de Física do Solo do mesmo Departamento. Os valores destas análises estão apresentados na Tabela 1. 
$\bar{\lambda}$

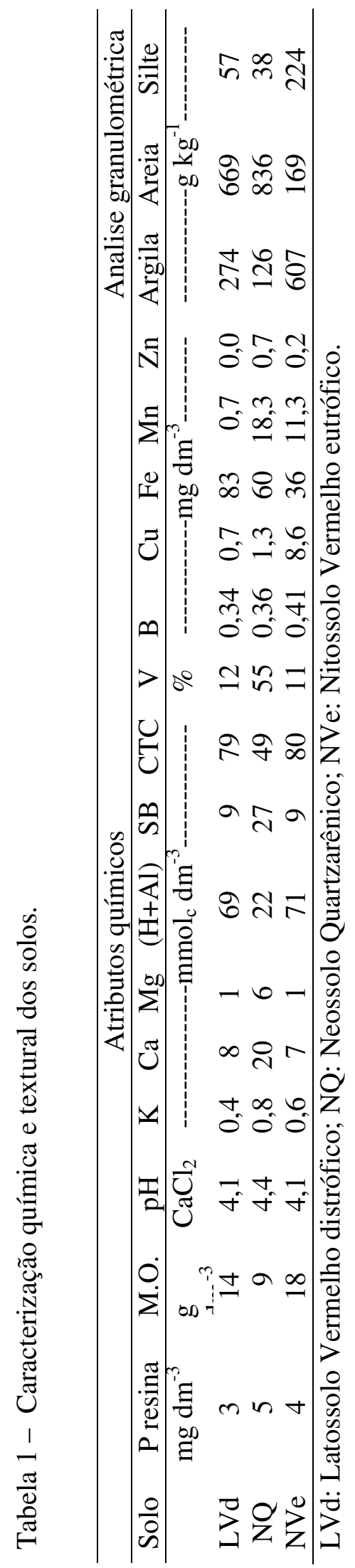




\subsection{Corretivos da acidez do solo}

Foram utilizados seis materiais corretivos da acidez do solo, sendo quatro silicatos: escória de aciaria, silicato de cálcio, silicato de cálcio e magnésio e wollastonita e dois calcários: dolomítico e calcítico. A escória de aciaria foi fornecida pela empresa Mannesmann, o silicato de cálcio pela empresa Silifertil, o silicato de cálcio e magnésio, pela Recmix e a wollastonita pela J. Reminas Mineração. Tendo em vista que os calcários são os materiais corretivos mais utilizados e os mais estudados, estes foram utilizados como referência.

As análises química e física dos materiais corretivos (Tabela 2) foram realizadas no Laboratório de Adubos e Corretivos do Departamento de Recursos Naturais Área Ciência do Solo da FCA/Unesp de Botucatu.

A avaliação química de corretivos da acidez dos solos para fins agrícolas consta da determinação do poder de neutralização (PN), e do cálcio e magnésio. Para esta avaliação utilizou-se o método oficial brasileiro definido para os calcários (BRASIL, 1986).

A análise física constituiu na determinação da composição granulométrica dos materiais, mediante a porcentagem de partículas retidas nas peneiras, ABNT $n^{\circ} 10(\varnothing=2 \mathrm{~mm}), \mathrm{ABNT}^{\circ} 20$ ( $\left.\varnothing=0,84 \mathrm{~mm}\right)$, ABNT $\mathrm{n}^{\circ} 50(\varnothing=0,30 \mathrm{~mm})$ e fundo $(\varnothing<0,30 \mathrm{~mm})$. A partir dos resultados da composição granulométrica calculou-se a reatividade (RE) dos materiais pela equação:

$$
\% \mathrm{RE}=\% \mathrm{~F}_{10} \times 0,0+\% \mathrm{~F}_{10-20} \times 0,2+\% \mathrm{~F}_{20-50} \times 0,6+\% \mathrm{~F}_{-50} \times 1
$$

Sendo:

$\% \mathrm{~F}_{10}=$ percentual de produto que fica retido na peneira $\mathrm{n}^{\circ} 10$;

$\% \mathrm{~F}_{10-20}=$ percentual de produto que passa pela peneira $\mathrm{n}^{\circ} 10$ e fica retido na peneira $\mathrm{n}^{\circ} 20$;

$\% \mathrm{~F}_{20-50}=$ percentual de produto que passa pela peneira $\mathrm{n}^{\circ} 20$ e fica retido na peneira $\mathrm{n}^{\circ} 50$ e $\mathrm{F}_{-50}=$ percentual de produto que passa pela peneira $\mathrm{n}^{\circ} 50$. 
Já o poder relativo de neutralização total (PRNT) foi obtido a partir da determinação dos valores de PN e RE, mediante a seguinte equação: PRNT = $(\mathrm{PN} x \mathrm{RE}) / 100$.

Tabela 2 - Análises químicas e físicas dos corretivos de acidez do solo utilizados no experimento.

\begin{tabular}{lrrrrrr}
\hline Características & Escória & $\begin{array}{c}\text { Silicato } \\
\text { de cálcio }\end{array}$ & $\begin{array}{c}\text { Silicato de } \\
\text { cálcio e } \\
\text { magnésio }\end{array}$ & Wollastonita & $\begin{array}{c}\text { Calcário } \\
\text { dolomítico }\end{array}$ & $\begin{array}{r}\text { Calcário } \\
\text { calcítico }\end{array}$ \\
\hline \multicolumn{7}{c}{$(\%)$} \\
\hline Umidade & 0,90 & 1,50 & 3,13 & 0,04 & 0,15 & 0,04 \\
$\mathrm{CaO}$ & 36,40 & 40,60 & 47,00 & 43,00 & 47,80 & 58,90 \\
$\mathrm{MgO}$ & 14,40 & 11,80 & 10,50 & 2,92 & 14,50 & 5,00 \\
\hline \multicolumn{7}{c}{ Passante (\%) } \\
\hline peneira $\mathrm{n}^{\circ} 10$ & 99,92 & 100,00 & 91,65 & 100,00 & 99,93 & 99,91 \\
peneira $\mathrm{n}^{\circ}$ 20 & 81,73 & 86,90 & 79,16 & 100,00 & 98,06 & 98,81 \\
peneira ${ }^{\circ} 50$ & 51,46 & 56,67 & 55,66 & 96,23 & 83,15 & 86,91 \\
\hline PN & 71,00 & 78,00 & 87,00 & 59,00 & 105,00 & 96,00 \\
RE & 73,26 & 77,43 & 72,26 & 60,00 & 92,47 & 94,27 \\
PRNT & 52,00 & 60,00 & 63,00 & 97,00 & 97,00 & 90,00 \\
\hline
\end{tabular}

\subsection{Experimento 1}

Realizado com o objetivo de se obter curvas de neutralização dos solos e equações matemáticas que determinassem a quantidade equivalente de óxidos de cálcio e magnésio necessários para elevar o $\mathrm{pH}_{\mathrm{CaCl}_{2}}$ dos solos a 5,5.

\subsubsection{Descrição dos tratamentos, delineamento experimental e análise estatística}

Os tratamentos consistiram das seis fontes de corretivos: wollastonita, silicato de cálcio, silicato de cálcio e magnésio, escória de aciaria, calcário dolomítico e calcário calcítico, separados em quatro frações granulométricas determinadas pela legislação brasileira, ABNT no $10(\varnothing=2 \mathrm{~mm})$, ABNT n $^{\circ} 20(\varnothing=0,84 \mathrm{~mm})$, ABNT $^{\circ} 50(\varnothing=0,30 \mathrm{~mm})$ e fundo $(\varnothing<0,30 \mathrm{~mm})$, exceto a wollastonita que possui apenas a fração granulométrica $<0,30$ mm. Aplicou-se quatro doses 1, 2, 4 e $8 \mathrm{t} \mathrm{ha}^{-1}$, mais uma testemunha, sem aplicação de corretivo. 
O delineamento experimental foi o inteiramente ao acaso em esquema fatorial 4 x $4+1$ ( 4 frações granulométricas x 4 doses +1 testemunha) com quatro repetições.

Para separação das frações granulométricas dos corretivos, utilizou-se o agitador mecânico, marca Telastem peneiras para análises LTDA, empregando-se as peneiras $n^{\circ} 10,20$ e 50. Transferiu-se a amostra do corretivo as peneiras encaixadas uma sobre a outra, em ordem crescente de abertura das malhas, ficando a de maior abertura de malha acima. Agitou-se com intensidade de vibração máxima durante 5 minutos.

Os tratamentos foram aplicados nos três solos descritos; desta forma, em cada solo aplicou-se as quatro doses para cada fração granulométrica dos respectivos corretivos. As unidades experimentais foram constituídas de saquinhos plásticos os quais receberam $500 \mathrm{~g}$ de solo. $\mathrm{O}$ corretivo e o solo de cada recipiente foram bem homogeneizados.

Durante o período de incubação a umidade dos solos foi mantida próxima a $70 \%$ da capacidade de campo, para isto realizaram-se pesagens semanais de quatro unidades experimentais, para a obtenção da média do solo a $70 \%$ da capacidade de campo, sendo que, valor abaixo desse padrão foi disponibilizado água na quantidade necessária para retornar à condição inicial.

Após os períodos de 30, 60 e 90 dias, foram coletadas amostras de solo, homogeneizando o total de solo de cada saquinho, seguido de retirada da amostra, a qual foi seca ao ar e peneirada em malha de $2 \mathrm{~mm}$. Em seguida determinou-se o $\mathrm{pH} \mathrm{em} \mathrm{CaCl}_{2}$ a 0,01 mol L-1 ( RAIJ et al., 2001).

Os dados foram analisados separadamente para cada tipo de corretivo em função de cada solo. Os valores de $\mathrm{pH}$ foram submetidos à análise de variância (teste $\mathrm{F}$ ), e quando houve diferença significativa foram submetidos à análise de regressão, escolhendo-se o modelo matemático de menor nível de significância, sempre inferiores a $5 \%$ de probabilidade (PIMENTEL GOMES, 1991). Utilizou-se o programa estatístico Sisvar 4,2 (FERREIRA, 2003).

Com os valores de pH obtidos no período de 90 dias de incubação, obteve-se as curvas de neutralização dos solos e as equações matemáticas pelas regressões significativas. Com as equações foi possível calcular a dose necessária para elevar o $\mathrm{pH}$ de cada solo a 5,5 de acordo com os corretivos e as frações granulométricas. Para o corretivo que na fração granulométrica 2,0 mm (peneira 10) não apresentou diferença significativa entre as 
doses, e, portanto não gerou regressão polimonial, adotou-se a equação obtida para a fração granulométrica 0,84 mm (peneira 20) (Tabelas 3, 4 e 5). 
Tabela 3. Equações e doses dos materiais corretivos necessárias para elevar o pH do Latossolo Vermelho distrófico (LVd) a 5,5 de acordo com as frações granulométricas obtidas no período de 90 dias de incubação.

\begin{tabular}{|c|c|c|c|}
\hline Corretivos & Peneiras & Equações & Doses $\left(\mathrm{t} \mathrm{ha}^{-1}\right)$ \\
\hline \multirow{4}{*}{ Escória } & 10 & $y=4,028923+0,179687 x-0,014470 x^{2}$ & 22,5 \\
\hline & 20 & $y=4,028923+0,179687 x-0,014470 x^{2}$ & 22,5 \\
\hline & 50 & $y=4,123000+0,104500 x$ & 13,2 \\
\hline & Fundo & $\mathrm{y}=4,108188+0,146437 \mathrm{x}$ & 9,5 \\
\hline \multirow{4}{*}{ Silicato de Cálcio } & 10 & $\mathrm{y}=4,138250+0,020250 \mathrm{x}$ & 67,2 \\
\hline & 20 & $y=4,129250+0,035750 x$ & 38,3 \\
\hline & 50 & $y=4,126500+0,129000 x$ & 10,6 \\
\hline & Fundo & $\mathrm{y}=4,114250+0,140750 \mathrm{x}$ & 9,8 \\
\hline \multirow{4}{*}{$\begin{array}{c}\text { Silicato de Cálcio e } \\
\text { Magnésio }\end{array}$} & 10 & $\mathrm{y}=4,100125+0,045125 \mathrm{x}$ & 31,0 \\
\hline & 20 & $y=4,116625+0,097125 x$ & 14,2 \\
\hline & 50 & $y=4,163000+0,134500 x$ & 9,9 \\
\hline & Fundo & $y=4,126625+0,161625 x$ & 8,5 \\
\hline \multirow{4}{*}{ Wollastonita } & 10 & --------- & ------ \\
\hline & 20 & --------- & ------ \\
\hline & 50 & -------- & ------- \\
\hline & Fundo & $y=4,080875+0,168875 x$ & 8,4 \\
\hline \multirow{4}{*}{$\begin{array}{l}\text { Calcário } \\
\text { Dolomítico }\end{array}$} & 10 & $y=4,143812+0,063563 x$ & 21,3 \\
\hline & 20 & $y=4,143812+0,063563 x$ & 21,3 \\
\hline & 50 & $y=4,052577+0,304547 x-0,015248 x^{2}$ & 7,8 \\
\hline & Fundo & $y=4,049692+0,318537 x-0,007959 x^{2}$ & 5,3 \\
\hline \multirow{4}{*}{ Calcário Calcítico } & 10 & $y=4,128615+0,032232 x+0,014305 x^{2}$ & 8,8 \\
\hline & 20 & $y=4,128615+0,032232 x+0,014305 x^{2}$ & 8,8 \\
\hline & 50 & $y=4,096375+0,221875 x$ & 6,3 \\
\hline & Fundo & $y=4,040115+0,307490 x-0,010211 x^{2}$ & 6,0 \\
\hline
\end{tabular}

Peneiras: Fundo: $\varnothing<0,30 \mathrm{~mm} ; 50: \varnothing=0,30 \mathrm{~mm} ; 20: \varnothing=0,84 \mathrm{~mm} ; 10: \varnothing=2 \mathrm{~mm}$. 
Tabela 4. Equações e doses dos materiais corretivos necessárias para elevar o pH do Neossolo Quartzarênio (NQ) a 5,5 de acordo com as frações granulométricas, obtidas no período de 90 dias de incubação.

\begin{tabular}{|c|c|c|c|}
\hline Corretivos & Peneiras & Equações & Doses $\left(\mathrm{t} \mathrm{ha}^{-1}\right)$ \\
\hline \multirow{4}{*}{ Escória } & 10 & $y=4,348125+0,085125 x$ & 13,5 \\
\hline & 20 & $y=4,348125+0,085125 x$ & 13,5 \\
\hline & 50 & $y=4,402062+0,178813 x$ & 6,1 \\
\hline & Fundo & $y=4,273769+0,453568 x-0,014175 x^{2}$ & 3,0 \\
\hline \multirow{4}{*}{ Silicato de Cálcio } & 10 & $y=4,373688+0,057437 x$ & 19,6 \\
\hline & 20 & $\mathrm{y}=4,374500+0,075500 x$ & 14,9 \\
\hline & 50 & $y=4,490813+0,111062 x$ & 9,1 \\
\hline & Fundo & $y=4,369769+0,476754 x-0,024296 x^{2}$ & 2,8 \\
\hline \multirow{2}{*}{ Silicato de Cálcio } & 10 & $y=4,408813+0,029062 x$ & 37,5 \\
\hline & 20 & $y=4,401188+0,120438 x$ & 9,1 \\
\hline \multirow[t]{2}{*}{ e Magnésio } & 50 & $y=4,320962+0,446057 x-0,015037 x^{2}$ & 3,0 \\
\hline & Fundo & $y=4,336538+0,545975 x-0,023027 x^{2}$ & 2,4 \\
\hline \multirow{4}{*}{ Wollastonita } & 10 & --------- & -------- \\
\hline & 20 & --------- & -------- \\
\hline & 50 & --------- & -------- \\
\hline & Fundo & $\mathrm{y}=4,350000+0,350000 x$ & 3,3 \\
\hline \multirow{2}{*}{ Calcário } & 10 & $y=4,440875+0,054375 x$ & 19,5 \\
\hline & 20 & $y=4,440875+0,054375 x$ & 19,5 \\
\hline \multirow[t]{2}{*}{ Dolomítico } & 50 & $y=4,374846+0,466123 x-0,027689 x^{2}$ & 3,0 \\
\hline & Fundo & $y=4,328462+0,868630 x-0,064432 x^{2}$ & 1,5 \\
\hline \multirow{4}{*}{ Calcário Calcítico } & 10 & $y=4,398500+0,054363 x-0,014476 x^{2}$ & 10,8 \\
\hline & 20 & $y=4,453437+0,129688 x$ & 8,1 \\
\hline & 50 & $y=4,334462+0,578275 x-0,035723 x^{2}$ & 2,3 \\
\hline & Fundo & $y=4,369769+0,782020 x-0,054578 x^{2}$ & 1,6 \\
\hline
\end{tabular}

Peneiras: Fundo: $\varnothing<0,30 \mathrm{~mm} ; 50: \emptyset=0,30 \mathrm{~mm} ; 20: \varnothing=0,84 \mathrm{~mm} ; 10: \varnothing=2 \mathrm{~mm}$. 
Tabela 5. Equações e doses dos materiais corretivos necessárias para elevar o pH do Nitossolo Vermelho eutrófico (NVe) a 5,5 de acordo com as frações granulométricas, obtidas no período de 90 dias de incubação.

\begin{tabular}{|c|c|c|c|}
\hline Corretivos & Peneiras & Equações & Doses $\left(\mathrm{t} \mathrm{ha}^{-1}\right)$ \\
\hline \multirow{4}{*}{ Escória } & 10 & $y=4,162937+0,026187 x$ & 51,1 \\
\hline & 20 & $y=4,162937+0,026187 x$ & 51,1 \\
\hline & 50 & $y=4,169000+0,057500 x$ & 23,1 \\
\hline & Fundo & $\mathrm{y}=4,125500+0,125500 \mathrm{x}$ & 11,0 \\
\hline \multirow{4}{*}{ Silicato de Cálcio } & 10 & $y=4,140875+0,017375 x$ & 78,2 \\
\hline & 20 & $y=4,170938+0,021687 x$ & 61,3 \\
\hline & 50 & $y=4,133885+0,053357 x+0,007267 x^{2}$ & 10,6 \\
\hline & Fundo & $y=4,108375+0,133875 x$ & 10,4 \\
\hline \multirow{2}{*}{ Silicato de Cálcio e } & 10 & $y=4,149563+0,017812 x$ & 75,8 \\
\hline & 20 & $y=4,148438+0,050187 x$ & 26,9 \\
\hline \multirow{2}{*}{ Magnésio } & 50 & $y=4,095563+0,116812 x$ & 12,0 \\
\hline & Fundo & $y=4,124062+0,129813 x$ & 10,6 \\
\hline \multirow{4}{*}{ Wollastonita } & 10 & --------- & ----- \\
\hline & 20 & --------- & ----- \\
\hline & 50 & --------- & ----- \\
\hline & Fundo & $y=4,076063+0,131312 x$ & 10,8 \\
\hline \multirow{4}{*}{ Calcário Dolomítico } & 10 & $\mathrm{y}=4,107250+0,070750 \mathrm{x}$ & 19,7 \\
\hline & 20 & $y=4,107250+0,070750 x$ & 19,7 \\
\hline & 50 & $y=4,143313+0,156062 x$ & 8,7 \\
\hline & Fundo & $y=4,163563+0,187812 x$ & 7,1 \\
\hline \multirow{4}{*}{ Calcário Calcítico } & 10 & $y=4,111875+0,062375 x$ & 22,3 \\
\hline & 20 & $y=4,111875+0,062375 x$ & 22,3 \\
\hline & 50 & $y=4,064625+0,180125 x$ & 8,0 \\
\hline & Fundo & $y=4,079875+0,193375 x$ & 7,3 \\
\hline
\end{tabular}

Peneiras: Fundo: $\varnothing<0,30 \mathrm{~mm} ; 50: \emptyset=0,30 \mathrm{~mm} ; 20: \varnothing=0,84 \mathrm{~mm} ; 10: \varnothing=2 \mathrm{~mm}$. 


\subsection{Experimento 2}

Realizado com a finalidade de calcular os valores de reatividade das frações granulométricas dos corretivos e avaliar a sua velocidade na neutralização da acidez dos solos.

\subsubsection{Descrição dos tratamentos, delineamento experimental e análise estatística}

Os tratamentos foram as seis fontes de corretivos: wollastonita, silicato de cálcio, silicato de cálcio e magnésio, escória de aciaria, calcário dolomítico e calcário calcítico, separados em quatro frações granulométricas $\mathrm{ABNT}^{\circ} 10(\varnothing=2 \mathrm{~mm}), \mathrm{ABNT}^{\circ} 20$ $(\varnothing=0,84 \mathrm{~mm}), \mathrm{ABNT}^{\mathrm{o}} 50(\varnothing=0,30 \mathrm{~mm})$ e fundo $(\varnothing<0,30 \mathrm{~mm})$, exceto a wollastonita que possui apenas a fração granulométrica $<0,30 \mathrm{~mm}$, e três épocas de amostragens $(30,60$ e 90 dias após incubação). Os tratamentos foram empregados nos mesmos três solos utilizados no experimento 1 , com quatro repetições.

O delineamento experimental foi inteiramente casualizado com parcelas subdivididas. As parcelas consistiram dos 6 materiais corretivos e das 4 frações granulométricas e na sub-parcela as épocas de amostragens de solo (30, 60 e 90 dias).

Aplicou-se as doses recomendadas no primeiro experimento, calculadas após 90 dias de incubação para atingir o pH 5,5. Desta maneira, objetivou-se aplicar doses equivalentes em $\mathrm{CaCO}_{3}$ e $\mathrm{CaSiO}_{3}$ para as frações granulométricas, tendo como fonte de variação apenas o tamanho das partículas.

Para separação das frações granulométricas dos corretivos procedeu da mesma maneira que no experimento 1. Com uso do agitador mecânico, empregou-se as peneiras $n^{\circ} 10,20$ e 50. Transferiu-se amostra do corretivo as peneiras encaixadas uma sobre a outra, em ordem crescente de abertura das malhas, ficando a de maior abertura de malha acima. Agitou-se com intensidade de vibração máxima durante 5 minutos.

As unidades experimentais, para cada tipo de solo, constituíram de recipientes plástico com tampas perfuradas, as quais receberam $1 \mathrm{~kg}$ de solo e a quantidade de corretivo necessária para elevar o $\mathrm{pH} \mathrm{CaCl}_{2}$ a 5,5 de acordo com a fração granulométrica, conforme obtido no experimento 1 (Tabelas 3, 4 e 5). 
A umidade dos solos foi mantida próximo a $70 \%$ da capacidade de campo, para isto realizaram-se pesagens semanais de quatro unidades experimentais de cada solo, para a obtenção da média do solo a $70 \%$ da capacidade de campo, sendo que, valores abaixo desse padrão foram disponibilizados quantidade de água na quantidade necessária para retornar a condição inicial.

Em cada período de incubação, que correspondeu aos 30, 60 e 90 dias, realizou-se amostragens do solo de cada unidade experimental, homogeneizando o total de solo seguido de retirada de $100 \mathrm{~g}$ de solo, o qual foi seco ao ar passado em peneira com malha de 2,0 mm e levado para laboratório.

As variáveis determinadas nas amostras de solo foram: $\mathrm{pH}$ em $\mathrm{CaCl}_{2}$; $\mathrm{H}+\mathrm{Al}$; P; Ca; Mg e K (RAIJ et al., 2001) sendo, em seguida, calculado soma de bases, capacidade de troca catiônica e saturação por bases dos solos.

A estimativa da eficiência na correção da acidez do solo de diferentes frações granulométricas é feita, geralmente, tomando-se como referencia uma fração ou material que apresente reação completa, e observando-se seu efeito sobre o $\mathrm{pH}$ do solo (BELLINGIERI, 1983). Em função disto, com a variação dos valores de pH ocorridos no período de 90 dias de incubação, avaliou-se a eficiência relativa das frações granulométricas dos corretivos. Tomou-se como referência o incremento promovido no $\mathrm{pH}$ de cada solo pelo calcário dolomítico na fração granulométrica $<0,30 \mathrm{~mm}$ (fração granulométrica que passou pela peneira 50) em relação ao $\mathrm{pH}$ inicial dos solos. Este acréscimo foi considerado $100 \%$, e assim pode-se obter o acréscimo das demais frações granulométricas e dos demais corretivos. A escolha como padrão, da fração $<0,30 \mathrm{~mm}$ (fundo) ocorreu pelo fato de ser essa fração utilizada para o calcário com $\mathrm{RE}=100 \%$, conforme a legislação brasileira.

Através dos valores de eficiência relativa de cada fração de acordo com o corretivo, calculou-se uma média para os solos estudados para cada corretivo. A partir desta média calculou-se a reatividade (RE) dos corretivos em função de suas composições granulométricas através da expressão: 


$$
\% \mathrm{ER}_{\text {corretivo }}=\mathrm{F}_{1} \times \frac{\mathrm{Er}_{1}}{100}+\mathrm{F}_{2} \times \frac{\mathrm{Er}_{2}}{100}+\ldots \ldots \ldots+\mathrm{Fn} \times \frac{\mathrm{Er}_{\mathrm{n}}}{100}
$$

Onde: $F_{1}, F_{2} \ldots . . F_{n}=$ percentual das diversas frações granulométricas.

$\mathrm{Er}_{1}, \mathrm{Er}_{2}, \ldots . \mathrm{n}=$ eficiência relativa percentual das respectivas frações granulométricas.

Em seguida calculou-se o Poder Relativo de Neutralização Total (PRNT) para cada material corretivo, utilizando a seguinte expressão:

$$
\mathrm{PRNT}=\frac{\mathrm{PN} \times \% \mathrm{ER}}{100}
$$

Sendo: $\mathrm{PN}=$ Poder de Neutralização, determinado em laboratório.

$\% \mathrm{ER}=$ eficiência relativa percentual em função da granulometria.

Com a realização dos cálculos descritos acima, obteve-se os valores de PRNT experimento (Tabela 6). O PRNT laboratório foi obtido pelo método oficial para calcários (BRASIL, 1986).

Tabela 6. Valores de PRNT laboratório e experimento, em função dos corretivos.

\begin{tabular}{lcc}
\hline \multicolumn{1}{c}{ Corretivos } & PRNT laboratório $^{1}$ & PRNT experimento $^{\circ}$ \\
\hline Escória & 52 & 82,90 \\
Silicato Cálcio & 60 & 83,30 \\
Silicato Cálcio e Magnésio & 63 & 101,40 \\
Wollastonita & 59 & 61,80 \\
Calcário Dolomítico & 97 & 104,70 \\
Calcário Calcítico & 90 & 98,40 \\
\hline
\end{tabular}

${ }^{1}$ Ver tabela 2

Para a análise estatística, as variáveis analisadas foram submetidas à análise de variância (teste F), e quando houve diferença significativa as variáveis qualitativas tiveram suas médias comparadas pelo teste Tukey a 5\% de probabilidade e as variáveis quantitativas foram submetidas à análise de regressão, escolhendo-se o modelo matemático de menor nível de significância, sempre inferiores a $5 \%$ de probabilidade pelo teste $\mathrm{F}$ 
(PIMENTEL GOMES, 1991). Para a determinação da análise de variância e do teste de média foi utilizado o programa Sisvar 4,2 (FERREIRA, 2003).

\subsection{Experimento 3}

O terceiro experimento foi realizado com o objetivo de comparar os valores pré-estabelecidos de reatividade dos silicatos, calculados no experimento 2 com os valores de reatividade determinados em laboratório.

Além das características químicas de solo, foi avaliada a produção de matéria seca de alfafa, o teor e o acúmulo de nutrientes com a finalidade de averiguar se o comportamento dos corretivos no solo seria adequado para o desenvolvimento da planta. A alfafa foi a planta teste escolhida por sua alta sensibilidade a acidez do solo.

\subsubsection{Descrição dos tratamentos, delineamento experimental e análise estatística}

Observa-se na Tabela 6, que para a wollastonita e para os calcários dolomítico e calcítico os valores dos PRNTs laboratório e experimento foram semelhantes. Isso mostra que, para esses três corretivos, o método da incubação não diferiu do oficial utilizado para os calcários. Desta forma, para estes corretivos o cálculo da necessidade de calagem foi realizado utilizando apenas o valor de PRNT laboratório, já que não justificaria aplicar doses tão próximas, as quais certamente, não mostrariam diferença significativa.

Entre os calcários decidiu-se utilizar apenas o dolomítico, tendo em vista que este foi o calcário utilizado para o cálculo da eficiência relativa das frações granulométricas. Assim, neste experimento o calcário dolomítico foi considerado como testemunha e foi referência na comparação para os demais tratamentos.

A escória, o silicato de cálcio e o silicato de cálcio e magnésio foram aplicados em duas doses, portanto, a necessidade de calagem foi calculada com base no PRNT obtido pelo experimento 2 e pelo PRNT laboratório (Tabela 6).

O delineamento experimental foi em blocos casualizados com 8 tratamentos. Os tratamentos foram as combinações entre os corretivos da acidez do solo: 
escória, silicato de cálcio, silicato de cálcio e magnésio, wollastonita e calcário dolomítico, e as doses, calculadas com o PRNT experimento e/ou laboratório.

Com os dois valores de PRNTs (laboratório e experimento) as doses foram calculadas com base na necessidade de calagem para elevar a saturação por bases de cada solo ao nível de 80 \%, de acordo com a recomendação para a alfafa Raij et al. (1996), aplicando-se a fórmula:

$$
\mathrm{NC}=\frac{(\mathrm{V} 2-\mathrm{V} 1) \mathrm{CTC}}{10 \times \mathrm{PRNT}}
$$

Sendo:

NC: Necessidade de Calagem/ corretivo $\left(\mathrm{t} \mathrm{ha}^{-1}\right)$

V2: Saturação por bases desejada para a cultura a ser implantada

V1: Saturação por bases atual do solo

CTC: Capacidade de Troca Catiônica do solo

PRNT: Pode Relativo de Neutralização Total do corretivo de acidez do solo

A partir do cálculo da necessidade de calagem, obteve-se as doses a serem empregadas de acordo com cada corretivo de acidez para cada tipo de solo, Tabela 7. A quantidade a ser aplicada por vaso, em gramas, foi calculada tomando-se por base o volume de 1 ha na profundidade de $0-20 \mathrm{~cm}$, considerando a capacidade do vaso de $12 \mathrm{~L}$.

$\mathrm{Na}$ ocasião da calagem realizou-se a adubação em todos os vasos. A adubação foi a mesma para todos os solos, e constou da aplicação de $150 \mathrm{mg} \mathrm{kg}^{-1}$ de $\mathrm{P}, 120$ $\mathrm{mg} \mathrm{kg}^{-1}$ de K. Utilizou-se como fonte o MAP e o cloreto de potássio, respectivamente. Os micronutrientes $\mathrm{Zn}, \mathrm{B}$, Cu e Fe foram fornecidos com a aplicação de 1g de óxidos silicatados (FTE BR12). O nitrogênio foi fornecido pelo fertilizante MAP e por meio da inoculação das sementes. Na alfafa, este nutriente pode ser suprido por meio da fixação simbiótica de bactérias aeróbicas da espécie Rhizobium melilotti fornecidas pela inoculação.

Para cada tratamento, procedeu-se a mistura dos fertilizantes e do material corretivo com auxílio de uma betoneira nas doses correspondentes de acordo com cada solo. A mistura foi colocada em vasos plásticos com capacidade de 12L. 
A umidade dos solos foi mantida próxima a $70 \%$ da capacidade de campo, pelo método das pesagens, realizadas semanalmente.

Os vasos foram mantidos abertos, e os tratamentos incubados por 30 dias. Após esse período realizou-se coleta de solo de cada unidade experimental, utilizando-se um trado. Coletou-se dois pontos, em seguida o solo foi homogeneizado, retirou-se $200 \mathrm{~g}$ para realizar a análise química, e o restante do solo foi devolvido ao vaso.

Tabela 7. Doses dos corretivos de acidez utilizadas no terceiro experimento.

\begin{tabular}{lccc}
\hline \multirow{2}{*}{ Corretivos } & & \multicolumn{2}{c}{${\text { Doses }\left(\mathrm{t} \mathrm{ha}^{-1}\right)}$} \\
\cline { 3 - 4 } Escória & Solos & PRNT Laboratório & PRNT experimento \\
& Latossolo & 10,33 & 6,48 \\
& Neossolo & 2,36 & 1,48 \\
& Nitossolo & 10,62 & 6,67 \\
\hline \multirow{3}{*}{ Silicato de Cálcio } & Latossolo & 8,95 & 6,45 \\
& Neossolo & 2,04 & 1,47 \\
& Nitossolo & 9,20 & 6,63 \\
\hline Silicato de Cálcio e & Latossolo & 8,53 & 5,30 \\
Magnésio & Neossolo & 1,94 & 1,21 \\
& Nitossolo & 8,76 & 5,44 \\
\hline \multirow{3}{*}{ Wollastonita } & Latossolo & 9,11 & ------ \\
& Neossolo & 2,08 & ------ \\
\multirow{2}{*}{ Calcário Dolomítico } & Nitossolo & 9,36 & -------- \\
\hline
\end{tabular}

A amostra de $200 \mathrm{~g}$ de solo foi seca ao ar, peneirada em malha de 2 mm, em seguida determinou-se o $\mathrm{pH}$ em $\mathrm{CaCl}_{2} ; \mathrm{H}+\mathrm{Al} ; \mathrm{P} ; \mathrm{Ca} ; \mathrm{Mg}$ e $\mathrm{K}$, e, posteriormente, calculado soma de bases, capacidade de troca catiônica e saturação por bases dos solos. Os micronutrientes $\mathrm{Cu}, \mathrm{Fe}, \mathrm{Mn}$ e $\mathrm{Zn}$ foram determinados pelo método do DTPA e o boro determinado em água quente (RAIJ et al., 2001) .

Após a coleta das amostras de solo, realizou-se a semeadura da alfafa. As sementes de alfafa cultivar Crioula foram inoculadas pelo método da inoculação direta. Colocou-se em um recipiente $200 \mathrm{~g}$ de sementes e $4 \mathrm{~g}$ de inoculante tipo turfa, adicionou-se suspensão aderente (água e açúcar na proporção 1:1), agitou-se até que todas as sementes entrassem em contato com a suspensão. 
Após 10 dias da semeadura realizou-se o primeiro desbaste, e com 20 dias após a semeadura realizou-se o último desbaste deixando 12 plantas por vaso até o final do experimento.

A reposição da água transpirada foi realizada de acordo com as necessidades das plantas, observado "in loco" em cada unidade experimental.

Aos 60 dias após o plantio, quando as plantas apresentavam pelo menos $10 \%$ de florescimento (aparecimento das primeiras flores), foi feito o primeiro corte a $10 \mathrm{~cm}$ do nível do solo. As plantas foram lavadas, em seguida, foram acondicionadas em sacos de papel e colocadas em estufa com ventilação forçada a $+/-65^{\circ} \mathrm{C}$, até peso constante, para determinação da matéria seca da parte aérea.

Depois de seco o material vegetal foi moído e submetido à análise para determinação dos teores de $\mathrm{N}, \mathrm{P}, \mathrm{K}, \mathrm{Ca}, \mathrm{Mg}, \mathrm{S}, \mathrm{Fe}, \mathrm{Cu}, \mathrm{Mn}, \mathrm{Zn}$ e $\mathrm{B}$ de acordo com a metodologia descrita por (MALAVOLTA et al., 1997).

Os nutrientes acumulados na parte aérea foram calculados multiplicando-se a matéria seca da parte aérea pelo teor do nutriente.

Após o corte das plantas coletou-se amostra de solo de cada vaso. Para tanto, utilizou-se um pequeno trado de rosca e coletou-se o solo em três pontos do vaso, de maneira a não prejudicar as plantas.

A amostra de $200 \mathrm{~g}$ de solo foi seca ao ar, peneirada em malha de 2 mm, em seguida determinou-se o $\mathrm{pH}$ em $\mathrm{CaCl}_{2} ; \mathrm{H}+\mathrm{Al}$; P; Ca; $\mathrm{Mg}$ e K (RAIJ et al., 2001) e foi calculado soma de bases, capacidade de troca catiônica e saturação por bases dos solos.

Aos 90 dias após o plantio, realizou-se o segundo corte coletando-se a parte aérea inteira, fazendo o corte rente a superfície do solo. Procedeu-se da mesma maneira que no primeiro corte para determinação da matéria seca, teor e acúmulo de macro e micro nutrientes do tecido vegetal.

Para a análise estatística os tratamentos foram submetidos à análise de variância (teste F), e quando houve diferença significativa entre os tratamentos as suas médias foram comparadas pelo teste Tukey a 5\% de probabilidade, utilizando o programa estatístico Sisvar 4.2 (FERREIRA, 2003). 


\section{RESULTADOS E DISCUSSÃO}

\subsection{Experimento 1}

\subsubsection{Latossolo Vermelho distrófico (LVd)}

A interação entre doses e frações granulométricas dos corretivos foi significativa na alteração do valor $\mathrm{pH}$ durante todo o período do experimento. As curvas de neutralização deste solo, de acordo com o corretivo utilizado, obtidas aos 30, 60 e 90 dias de incubação estão representadas na Figura 1.

Verificou-se, de maneira geral, elevação no valor de $\mathrm{pH}$ com o aumento da dose de corretivo e com a diminuição da fração granulométrica.

A velocidade de reação foi maior no período de trinta dias de incubação em relação aos períodos seguintes e em todos os corretivos avaliados, a elevação do $\mathrm{pH}$ esteve diretamente relacionada à diminuição do tamanho das partículas. Tal fato decorre das frações mais finas se solubilizarem rapidamente no solo.

Os calcários foram mais eficientes no aumento do $\mathrm{pH}$ do solo. Os silicatos tiveram comportamento muito semelhante entre si, as pequenas diferenças foram: o silicato de cálcio e magnésio apresentou reação pouco superior aos trinta e sessenta dias de incubação nas frações $<0,30 \mathrm{~mm}$ e de $0,30 \mathrm{~mm}$ e na fração de $0,84 \mathrm{~mm}$ aos noventa dias. 

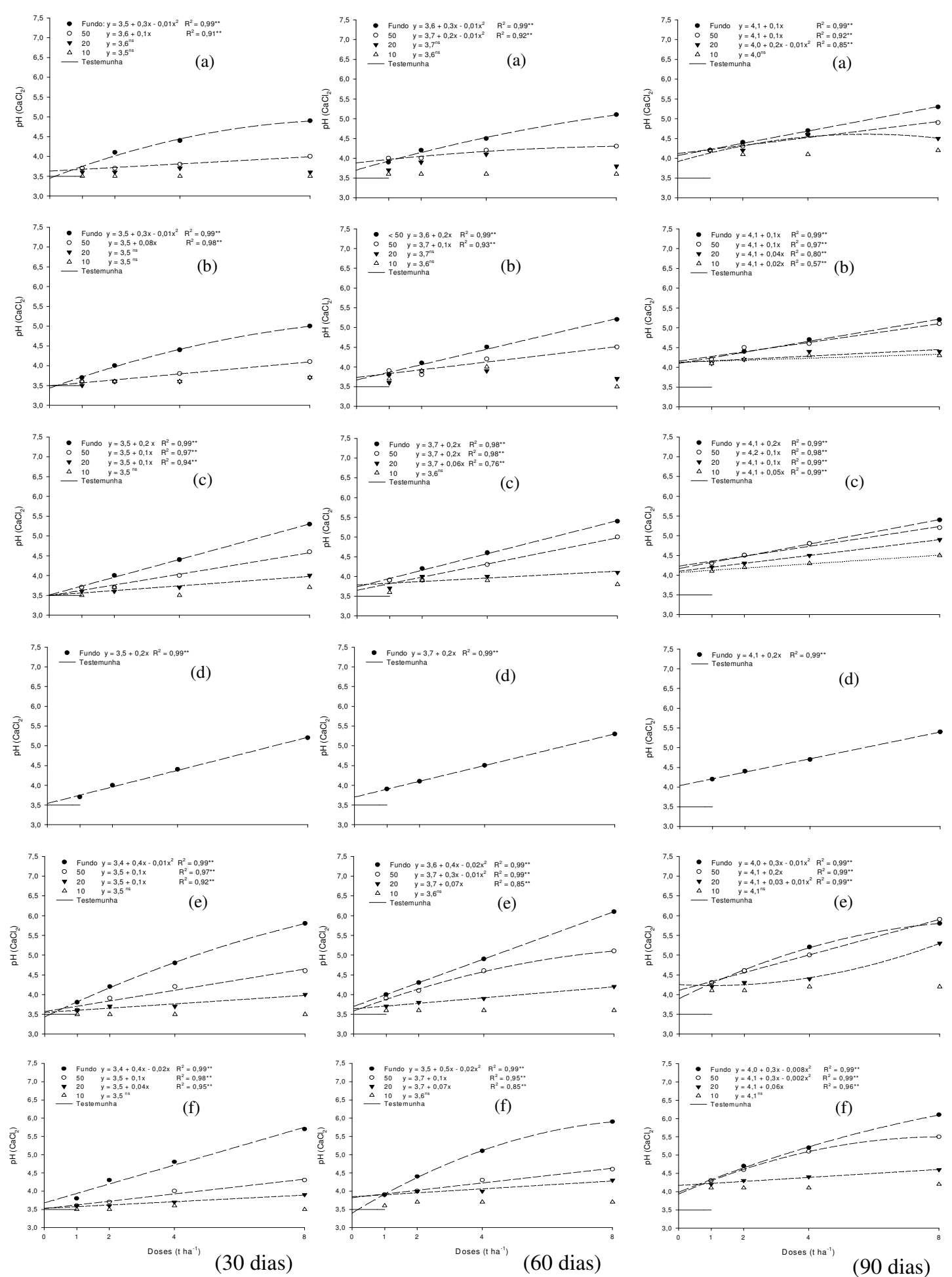

Figura 1. Desdobramento das interações doses e granulometrias (Fundo: $\varnothing<0,30 \mathrm{~mm} ; 50: \varnothing=0,30 \mathrm{~mm} ; 20: \varnothing=0,84 \mathrm{~mm} ; 10$ : $\emptyset=2 \mathrm{~mm}$ ) para valores de pH do Latossolo Vermelho distrófico (LVd) com a aplicação de escória (a), silicato de cálcio (b), silicato de cálcio e magnésio (c), wollastonita ${ }^{1}$ (d), calcário calcítico (e) e calcário dolomítico (f), aos 30, 60 e 90 dias de incubação. ** significativo a $1 \%$ de probabilidade. ns- não significativo. ${ }^{1}$ possui apenas a fração granulométrica $<0,30 \mathrm{~mm}$. 
Observa-se que após noventa dias de incubação do solo, os calcários foram os que apresentaram maior efeito corretivo proporcionando $\mathrm{pH}$ de 5,8 e 6,1, vindo a seguir a wollastonita e o silicato de cálcio e magnésio com 5,4.

A elevação do $\mathrm{pH}$ pela aplicação de partículas maiores, $0,84 \mathrm{~mm}$ e 2,0 $\mathrm{mm}$ (peneira 10 e peneira 20), foi menor e teve reação mais lenta no solo, necessitando de maior período de incubação. A fração $0,84 \mathrm{~mm}$ promoveu pequena elevação no valor de $\mathrm{pH}$ do solo aos trinta e sessenta dias de incubação, observando-se melhor correção da acidez com esta fração aos noventa dias. Já a fração $2 \mathrm{~mm}$ aos trinta e sessenta dias de incubação não proporcionou qualquer alteração no valor de $\mathrm{pH}$, apenas aos noventa dias de incubação a aplicação de silicato de cálcio e de silicato de cálcio e magnésio proporcionou pequena elevação do $\mathrm{pH}$, chegando apenas ao $\mathrm{pH}$ 4,3 e 4,5 respectivamente.

A baixa reatividade dessa fração granulométrica também foi observada por Bellingieri et al. (1989) utilizando diferentes calcários, e por Prado et al. (2004) com aplicação de escórias. Estes autores ainda concluem que a fração mais grosseira da escória é ineficiente na neutralização da acidez do solo, mesmo com a aplicação de doses elevadas e por um período de incubação de até 270 dias.

Comparando silicatos e calcários, verifica-se que os silicatos tiveram menor eficiência na correção da acidez do solo, o comportamento distinto de calcário e escória, com superioridade do calcário na neutralização da acidez, também foi relatado por Prado et al. (2004).

No período de noventa dias a maioria dos corretivos na fração 0,30 $\mathrm{mm}$ tendeu a se igualar com a fração $<0,30 \mathrm{~mm}$, fato também verificado por Bellingieri (1983) avaliando calcários.

Verifica-se que as menores doses aplicadas ( 1 e $\left.2 \mathrm{t} \mathrm{ha}^{-1}\right)$, independente da fração granulométrica, foram muito próximas na alteração dos valores de $\mathrm{pH}$. A partir da aplicação de $4 \mathrm{t} \mathrm{ha}^{-1}$ é que observou-se maior diferenciação nos valores de $\mathrm{pH}$ em função das frações granulométricas.

Com os valores de $\mathrm{pH}$ obtidos no período de noventa dias de incubação foi possível obter as equações matemáticas para calcular a dose a ser utilizada no segundo experimento para elevar o $\mathrm{pH}$ do solo a 5,5 de acordo com o material corretivo e a fração granulométrica. As equações e as doses estão na Tabela 3. 
Verifica-se que apenas os calcários atingiram o pH desejado, 5,5, nas frações < 0,30 mm e de 0,30 mm; entretanto, foi possível estimar a dose para alcançar o $\mathrm{pH}$ 5,5 nos demais corretivos por meio das equações obtidas pelas regressões polimoniais significativas.

A escória, o calcário dolomítico e o calcário calcítico na granulometria 2,0 mm (peneira 10) não apresentaram diferença significativa entre as doses. Portanto, não gerou regressão polimonial, desta forma para estes corretivos, nesta fração granulométrica, adotou-se a equação obtida para a granulometria $0,84 \mathrm{~mm}$ (peneira 20) (Tabela 3).

\subsubsection{Nitossolo Vermelho eutrófico (NVe)}

A interação entre doses e frações granulométricas dos corretivos foi significativa durante todo o período do experimento. As curvas de neutralização estão representadas na Figura 2.

Para este solo a velocidade de reação também foi maior no período de trinta dias de incubação em relação aos períodos seguintes, e para todos os corretivos avaliados, a elevação do pH se deu com a diminuição do tamanho das partículas e aumento das doses (Figura 2).

A fração $0,84 \mathrm{~mm}$ dos silicatos somente aos noventa dias de incubação é que promoveu elevação no valor de $\mathrm{pH}$, já para os calcários esta fração granulométrica mostrou diferença significativa entre as doses aos sessenta dias de incubação.

Todos os corretivos na granulometria $2 \mathrm{~mm}$ aos trinta e sessenta dias de incubação não proporcionaram qualquer alteração nos valores de pH. Apenas com noventa dias de incubação o silicato de cálcio e o silicato de cálcio e magnésio apresentaram diferenças significativas, mas com pequena elevação no valor de $\mathrm{pH}$.

Os valores de $\mathrm{pH}$ obtidos no período de noventa dias com aplicação das frações $<0,30 \mathrm{~mm}$ (peneira fundo) dos corretivos, com exceção da escória, tendeu a se igualar com as frações de $0,30 \mathrm{~mm}$ (peneira 50), semelhante ao ocorrido no LVd e também relatado por Bellingieri (1983). 

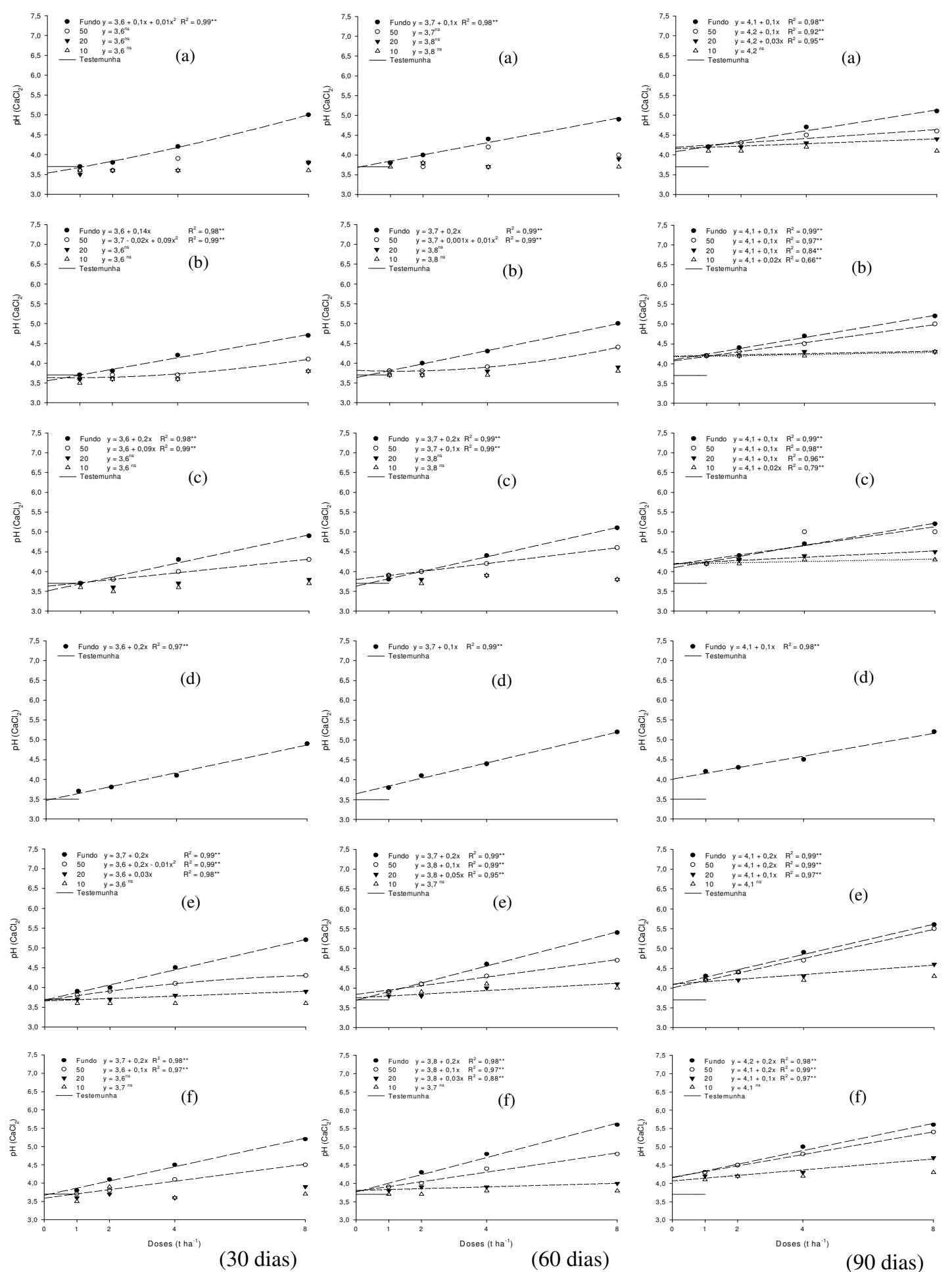

Figura 2. Desdobramento das interações doses e granulometrias (Fundo: $\varnothing<0,30 \mathrm{~mm} ; 50: \emptyset=0,30 \mathrm{~mm} ; 20: \emptyset=0,84 \mathrm{~mm} ; 10$ : $\emptyset=2 \mathrm{~mm}$ ) para valores de $\mathrm{pH}$ do Nitossolo Vermelho eutrófico (NVe) com a aplicação de escória (a), silicato de cálcio (b), silicato de cálcio e magnésio (c), wollastonita ${ }^{1}$ (d), calcário calcítico (e) e calcário dolomítico (f), aos 30, 60 e 90 dias de incubação. ** significativo a $1 \%$ de probabilidade. ns- não significativo. ${ }^{1}$ possui apenas a fração granulométrica $<0,30 \mathrm{~mm}$. 
As menores doses aplicadas ( 1 e $\left.2 \mathrm{t} \mathrm{ha}^{-1}\right)$, independente da fração granulométrica foram muito próximas na alteração do $\mathrm{pH}$, assim como verificado para o LVd foi a partir da aplicação de $4 \mathrm{t} \mathrm{ha}^{-1}$ que se teve maior alteração do $\mathrm{pH}$ em função das frações granulométricas (Figura 2).

Os maiores valores de $\mathrm{pH}$ foram obtidos com a aplicação dos calcários. $\mathrm{O}$ pH de 5,5 somente foi alcançado na dose de $8 \mathrm{t} \mathrm{ha}^{-1}$ pelo calcário calcítico na fração granulométrica de $0,30 \mathrm{~mm}$ e $<0,30 \mathrm{~mm}$ aos noventa dias de incubação e pelo calcário dolomítico na na fração granulométrica $<0,30 \mathrm{~mm}$ também com a dose máxima aos sessenta dias de incubação.

Com os valores de $\mathrm{pH}$ obtidos no período de noventa dias de incubação foi possível obter as equações matemáticas para calcular a dose a ser utilizada no segundo experimento para elevar o $\mathrm{pH}$ do solo a 5,5 de acordo com o material corretivo e a fração granulométrica. As equações e as doses estão na Tabela 4.

A escória, o calcário dolomítico e o calcário calcítico na fração granulométrica 2,0 mm (peneira 10) não apresentaram diferença significativa entre as doses. Portanto, não gerou regressão polimonial, desta forma para estes corretivos nesta fração granulométrica adotou-se a equação obtida para a fração granulométrica de $0,84 \mathrm{~mm}$ (peneira 20) (Tabela 4).

\subsubsection{Neossolo Quartzarênico (NQ)}

A interação entre doses e frações granulométricas dos corretivos foi significativa na alteração do valor de $\mathrm{pH}$ durante todo o período do experimento. As curvas de neutralização deste solo de acordo com o corretivo obtidas aos 30, 60 e 90 dias de incubação estão representadas na Figura 3.

$\mathrm{O}$ aumento no valor de $\mathrm{pH}$ deu-se com o aumento da dose aplicada e diminuição do tamanho das partículas dos corretivos, como também verificado para o LVd e para o NVe.

Observa-se que este solo respondeu a aplicação dos tratamentos de maneira diferente dos outros dois solos. Os silicatos e calcários foram, de maneira geral, semelhantes na elevação do valor de $\mathrm{pH}$. 

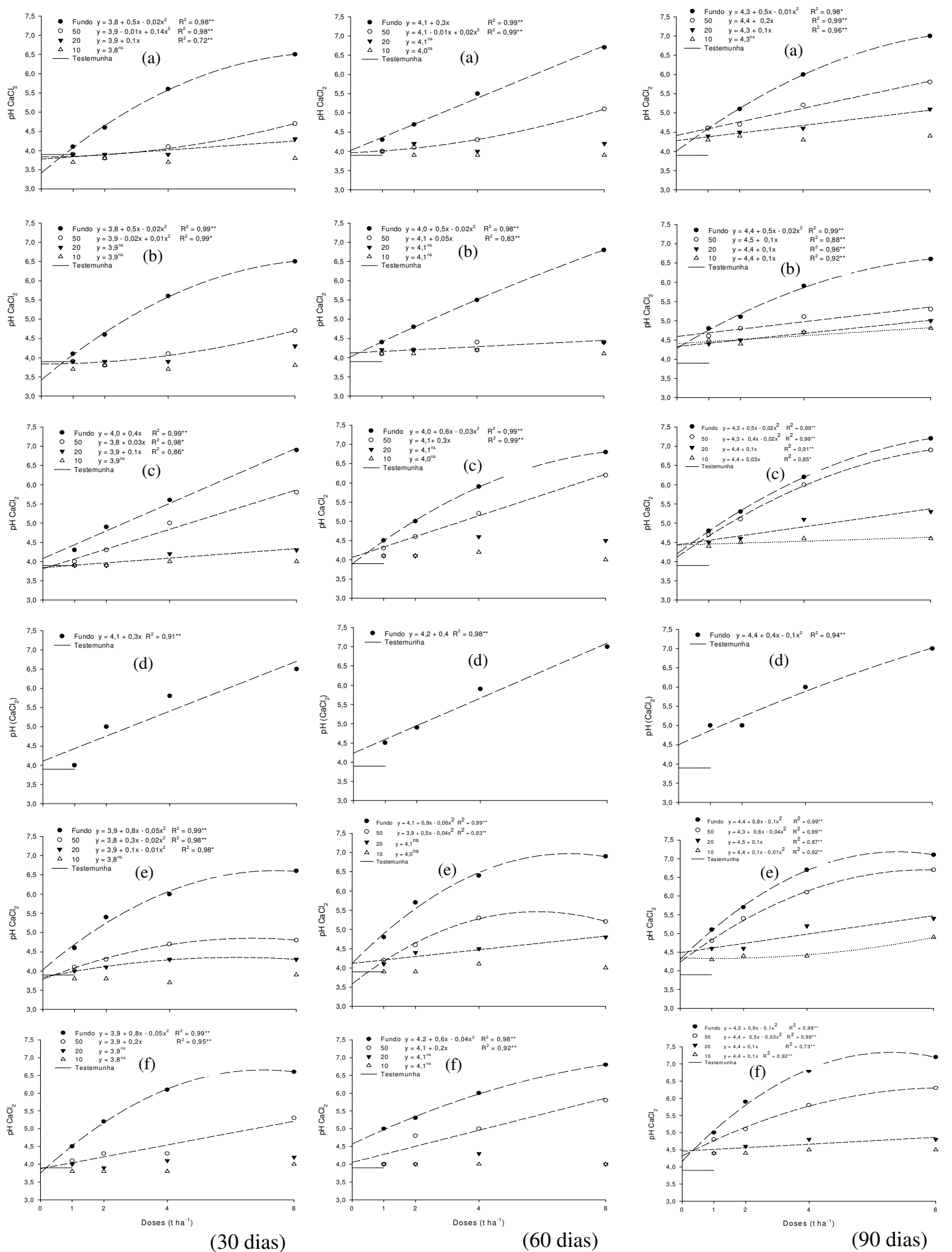

Figura 3. Desdobramento das interações doses e granulometrias (Fundo: $\varnothing<0,30 \mathrm{~mm} ; 50: \varnothing=0,30 \mathrm{~mm}$; $20: \emptyset=0,84 \mathrm{~mm}$; 10: $\varnothing=2 \mathrm{~mm}$ ) para valores de $\mathrm{pH}$ do Neossolo Quartzarênico (NQ) com a aplicação de escória (a), silicato de cálcio (b), silicato de cálcio e magnésio (c), wollastonita ${ }^{1}$ (d), calcário calcítico (e) e calcário dolomítico (f), aos 30, 60 e 90 dias de incubação. ** significativo a $1 \%$ de probabilidade. ns- não significativo. ${ }^{1}$ possui apenas a fração granulométrica $<0,30 \mathrm{~mm}$ 
Com apenas 30 dias de incubação todos os corretivos na granulometria $<0,30 \mathrm{~mm}$ atingiram o $\mathrm{pH}$ planejado de 5,5, o silicato de cálcio e magnésio também chegou ao $\mathrm{pH}$ 5,5 na granulometria de $0,30 \mathrm{~mm}$ já aos trinta dias.

As maiores partículas dos corretivos $0,84 \mathrm{~mm}$ e 2,0 $\mathrm{mm}$ (peneira $10 \mathrm{e}$ 20) mostraram-se com menor reatividade como já esperado, com diferença significativa entre as doses somente a partir do período de noventa dias.

Diferentemente do LVd e NVe, este solo mostrou diferença entre as granulometrias na elevação do pH já com a aplicação das menores doses, e esta diferença se acentuou nas maiores doses (Figura 3).

Comparando-se as curvas de neutralização (Figuras 1, 2 e 3), observase que o NQ teve seu valor de $\mathrm{pH}$ mais alto e foi o solo mais influenciado pela aplicação dos tratamentos, atingindo $\mathrm{pH}$ de 7,2 com a aplicação do silicato de cálcio e magnésio e do calcário dolomítico. A maior reatividade para este solo foi observada para todos os corretivos aplicados, tal fato é explicado pelo menor teor de matéria orgânica, menor teor de argila e maior teor de areia neste solo do que no LVd e NVe, e essas características condicionam baixa CTC, menor poder tampão do solo que fizeram com que os tratamentos aumentassem rapidamente o $\mathrm{pH}$ deste solo.

Assim como feito para o LVd e NVe aos noventa dias de incubação, obteve-se as equações matemáticas para calcular a dose a ser utilizada no segundo experimento para elevar o pH do solo a 5,5 de acordo com o material corretivo e a fração granulométrica.

As equações e as doses estão na Tabela 5. Apenas a escória na fração granulométrica 2,0 mm (peneira 10) não apresentou diferença significativa entre as doses. Portanto, não gerou regressão polinomial, desta forma utilizou-se para esta fração granulométrica a equação obtida para a fração granulométrica de 0,84 mm (peneira 20) deste corretivo (Tabela 5). 


\subsection{Experimento 2}

Neste experimento avaliou-se os efeitos de corretivos, frações granulométricas dos corretivos e períodos de incubação nos atributos químicos dos solos; quando significativos foram desdobrados.

A wollastonita foi considerada como um tratamento adicional por possuir apenas uma fração granulométrica, assim a análise estatística foi realizada separadamente comparando-se os corretivos na fração granulométrica $<0,30 \mathrm{~mm}$ (peneira fundo).

É importante lembrar que as doses aplicadas diferiram para cada fração granulométrica de acordo com o corretivo para elevar o $\mathrm{pH}$ de cada solo a 5,5.

\subsubsection{Latossolo Vermelho distrófico (LVd)}

As interações corretivos $\mathrm{x}$ granulometrias aos 30, 60 e 90 dias de incubação foram significativas para o $\mathrm{pH} \mathrm{CaCl}$; $\mathrm{H}+\mathrm{Al} ; \mathrm{Ca} ; \mathrm{Mg} ; \mathrm{SB}$; CTC e V\%, cujos desdobramentos estão apresentados nas Tabelas 8, 9 e 10.

Para avaliar a velocidade na neutralização da acidez dos solos pelos corretivos, analisou-se para cada corretivo o efeito da granulometria no decorrer dos períodos de incubação. A interação granulometrias x períodos de incubação foi significativa nos valores de $\mathrm{pH}$ e $\mathrm{H}+\mathrm{Al}$ (Figura 4); teor de potássio, cálcio e magnésio (Figura 5) e nos valores de SB, CTC e V\% (Figura 6) para todos os corretivos.

Observando-se o pH do solo após trinta dias de incubação (Tabela 8) verifica-se que apenas as partículas $<0,30 \mathrm{~mm}$ (peneira fundo) de todos os corretivos e a partícula de 0,30 mm (peneira 50) do silicato de cálcio e magnésio atingiram o pH 5,5, no entanto, no decorrer dos períodos as demais frações granulométricas atingiram o $\mathrm{pH}$ planejado, chegando em muitos casos a valores superiores.

Verifica-se para todos os corretivos na primeira e segunda avaliação (30 e 60 dias de incubação), Tabelas 8 e 9, que a fração granulométrica $<0,30 \mathrm{~mm}$ foi significativamente superior as demais granulometrias, entretanto, na terceira avaliação (90 dias), Tabela 10, as demais granulometrias tenderam a se igualar com a fração granulométrica 
$<0,30 \mathrm{~mm}$, chegando até mesmo a não haver diferença significativa entre as granulometrias para o silicato de cálcio e silicato de cálcio e magnésio. Isto mostra a diferença de reação no solo em função do tamanho das partículas, mesmo com a aplicação de doses elevadas as frações mais grosseiras precisaram de um período maior para reação no solo e então começarem a ter efeito na neutralização da acidez do solo do que partículas finas que rapidamente neutralizam e corrigem a acidez.

A aplicação das partículas retidas na peneira 10 (2,00 mm) não atingiu o pH desejado, isto já era esperado, visto que para esta fração granulométrica não foi possível calcular a dose a ser aplicada por falta de equação significativa.

Observou-se diferença na velocidade de reação de neutralização da acidez do solo de um mesmo tamanho de partícula para os corretivos. Aos trinta dias de incubação ocorreu variação significativa entre os corretivos em todas as frações granulométricas (Tabela 8), já na segunda avaliação (60 dias) (Tabela 9) os corretivos não diferiram na granulometria $<0,30 \mathrm{~mm}$ e na terceira avaliação (90 dias) (Tabela 10) os corretivos não diferiram na granulometria $<0,30 \mathrm{~mm}$ e $0,30 \mathrm{~mm}$, exceto apenas o silicato de cálcio e magnésio que diferiu dos calcários na granulometria $0,30 \mathrm{~mm}$. Pode ser que com maior período de incubação essa diferença diminuísse e assim as demais frações granulométricas não apresentassem diferença entre os corretivos.

Os valores de $\mathrm{pH}$ foram influenciados pela interação períodos de incubação e granulometria dos corretivos (Figura 4), para todas as frações granulométricas nas quais a interação foi significativa ocorreu elevação no pH do solo no decorrer da incubação, exceto os calcários na granulometria 2,0 $\mathrm{mm}$ que teve o valor do $\mathrm{pH}$ reduzido aos noventa dias de incubação.

A acidez potencial seguiu os resultados obtidos com o $\mathrm{pH}$, ou seja, os maiores valores de $\mathrm{pH}$ apresentaram os menores valores de $\mathrm{H}+\mathrm{Al}$. A diminuição da acidez potencial ocorreu com a diminuição das frações granulométricas (Tabelas 8, 9 e 10) e foi influenciada significativamente pela interação período de incubação e granulometria do corretivo (Figura 4). A acidez potencial foi neutralizada no decorrer da incubação. 
Tabela 8 - Desdobramento das interações corretivos x granulometrias para atributos químicos do Latossolo Vermelho distrófico (LVd) após 30 dias de incubação.

\begin{tabular}{|c|c|c|c|c|}
\hline \multirow{2}{*}{ Corretivos } & \multicolumn{4}{|c|}{ Granulometrias } \\
\hline & $<0,30$ & 0,30 & 0,84 & 2,00 \\
\hline & \multicolumn{4}{|c|}{$\mathrm{pH}\left(\mathrm{CaCl}_{2}\right)$} \\
\hline Escória & $5,7 \mathrm{bcA}$ & $5,4 \mathrm{aB}$ & $4,6 \mathrm{bC}$ & $4,3 \mathrm{cD}$ \\
\hline Silicato de cálcio & 5,8 abc A & $5,2 \mathrm{abB}$ & $5,0 \mathrm{aBC}$ & $5,0 \mathrm{aC}$ \\
\hline Silicato de cálcio e magnésio & $6,0 \mathrm{aA}$ & $5,5 \mathrm{aB}$ & $5,0 \mathrm{aC}$ & $4,7 \mathrm{bD}$ \\
\hline Calcário calcítico & $5,9 \mathrm{abA}$ & $5,1 \mathrm{bcB}$ & $4,4 \mathrm{bC}$ & $4,1 \mathrm{cC}$ \\
\hline Calcário dolomítico & $5,6 \mathrm{cA}$ & $4,9 \mathrm{cB}$ & $4,9 \mathrm{aB}$ & $4,2 \mathrm{cC}$ \\
\hline \multirow[t]{2}{*}{$\mathrm{CV} \%$} & \multicolumn{4}{|c|}{2,7} \\
\hline & \multicolumn{4}{|c|}{$\mathrm{H}+\mathrm{Al}\left(\mathrm{mmol}_{\mathrm{c}} \mathrm{dm}^{-3}\right)$} \\
\hline Escória & $22 \mathrm{aC}$ & $30 \mathrm{bB}$ & $50 \mathrm{abA}$ & $56 \mathrm{bA}$ \\
\hline Silicato de cálcio & $22 \mathrm{aC}$ & $33 \mathrm{bB}$ & $41 \mathrm{cA}$ & $38 \mathrm{dAB}$ \\
\hline Silicato de cálcio e magnésio & $20 \mathrm{aD}$ & $31 \mathrm{bC}$ & $39 \mathrm{cB}$ & $47 \mathrm{cA}$ \\
\hline Calcário calcítico & $22 \mathrm{aD}$ & $35 \mathrm{abC}$ & $55 \mathrm{aB}$ & $65 \mathrm{aA}$ \\
\hline Calcário dolomítico & $24 \mathrm{aC}$ & $42 \mathrm{aB}$ & $45 \mathrm{bcB}$ & $63 \mathrm{abA}$ \\
\hline \multirow[t]{2}{*}{$\mathrm{CV} \%$} & \multicolumn{4}{|c|}{9,8} \\
\hline & \multicolumn{4}{|c|}{$\mathrm{Ca}\left(\mathrm{mmol}_{\mathrm{c}} \mathrm{dm}^{-3}\right)$} \\
\hline Escória & $45 \mathrm{aA}$ & $48 \mathrm{aA}$ & $24 \mathrm{abB}$ & $15 \mathrm{bC}$ \\
\hline Silicato de cálcio & $44 \mathrm{aA}$ & $34 \mathrm{aB}$ & $28 \mathrm{aB}$ & $32 \mathrm{aB}$ \\
\hline Silicato de cálcio e magnésio & $42 \mathrm{aA}$ & $38 \mathrm{aB}$ & $28 \mathrm{aB}$ & $19 \mathrm{bB}$ \\
\hline Calcário calcítico & $40 \mathrm{aA}$ & $33 \mathrm{abA}$ & $17 \mathrm{bB}$ & $11 \mathrm{bB}$ \\
\hline Calcário dolomítico & $30 \mathrm{bA}$ & $27 \mathrm{aAB}$ & $20 \mathrm{abBC}$ & $12 \mathrm{bC}$ \\
\hline \multirow[t]{2}{*}{$\mathrm{CV} \%$} & \multicolumn{4}{|c|}{14,9} \\
\hline & \multicolumn{4}{|c|}{$\mathrm{Mg}\left(\mathrm{mmol}_{\mathrm{c}} \mathrm{dm}^{-3}\right)$} \\
\hline Escória & $9 \mathrm{bA}$ & $7 \mathrm{bcA}$ & $2 \mathrm{bB}$ & $2 \mathrm{aB}$ \\
\hline Silicato de cálcio & $9 \mathrm{bA}$ & $6 \mathrm{cB}$ & $2 \mathrm{bC}$ & $2 \mathrm{aC}$ \\
\hline Silicato de cálcio e magnésio & $13 \mathrm{aA}$ & $9 \mathrm{bB}$ & $4 \mathrm{bC}$ & $1 \mathrm{aD}$ \\
\hline Calcário calcítico & $7 \mathrm{cA}$ & $8 \mathrm{bA}$ & $3 \mathrm{bB}$ & $2 \mathrm{aB}$ \\
\hline Calcário dolomítico & $13 \mathrm{aA}$ & $12 \mathrm{aA}$ & $7 \mathrm{aB}$ & $3 \mathrm{aC}$ \\
\hline \multirow[t]{2}{*}{ CV \% } & \multicolumn{4}{|c|}{16,7} \\
\hline & \multicolumn{4}{|c|}{$\mathrm{K}\left(\mathrm{mmol}_{\mathrm{c}} \mathrm{dm}^{-3}\right)$} \\
\hline Escória & $9 \mathrm{bA}$ & $7 \mathrm{bcA}$ & $2 \mathrm{bB}$ & $2 \mathrm{aB}$ \\
\hline Silicato de cálcio & $9 \mathrm{bA}$ & $6 \mathrm{cB}$ & $2 \mathrm{bC}$ & $2 \mathrm{aC}$ \\
\hline Silicato de cálcio e magnésio & $13 \mathrm{aA}$ & $9 \mathrm{bB}$ & $4 \mathrm{bC}$ & $1 \mathrm{aD}$ \\
\hline Calcário calcítico & $7 \mathrm{cA}$ & $8 \mathrm{bA}$ & $3 \mathrm{bB}$ & $2 \mathrm{aB}$ \\
\hline Calcário dolomítico & $13 \mathrm{aA}$ & $12 \mathrm{aA}$ & $7 \mathrm{aB}$ & $3 \mathrm{aC}$ \\
\hline \multirow[t]{2}{*}{$\mathrm{CV} \%$} & \multicolumn{4}{|c|}{36,4} \\
\hline & \multicolumn{4}{|c|}{$\mathrm{SB}\left(\mathrm{mmol}_{\mathrm{c}} \mathrm{dm}^{-3}\right)$} \\
\hline Escória & $54 \mathrm{aA}$ & $56 \mathrm{aA}$ & $26 \mathrm{abB}$ & $17 \mathrm{bB}$ \\
\hline Silicato de cálcio & $54 \mathrm{aA}$ & $39 \mathrm{bB}$ & $30 \mathrm{abB}$ & $34 \mathrm{aB}$ \\
\hline Silicato de cálcio e magnésio & $55 \mathrm{aA}$ & $47 \mathrm{abA}$ & $32 \mathrm{aB}$ & $21 \mathrm{bC}$ \\
\hline Calcário calcítico & $47 \mathrm{abA}$ & $41 \mathrm{bA}$ & $20 \mathrm{bB}$ & $12 \mathrm{bB}$ \\
\hline Calcário dolomítico & $43 \mathrm{bA}$ & $38 \mathrm{bA}$ & $27 \mathrm{abB}$ & $15 \mathrm{bC}$ \\
\hline $\mathrm{CV} \%$ & & & & \\
\hline & & $\mathrm{CT}$ & & \\
\hline Escória & $75 \mathrm{aB}$ & $86 \mathrm{aA}$ & $76 \mathrm{aB}$ & $73 \mathrm{abB}$ \\
\hline Silicato de cálcio & $75 \mathrm{aA}$ & $72 \mathrm{bA}$ & $71 \mathrm{aA}$ & 73 abA \\
\hline Silicato de cálcio e magnésio & $75 \mathrm{aAB}$ & $78 \mathrm{abA}$ & $72 \mathrm{aAB}$ & $67 \mathrm{bB}$ \\
\hline Calcário calcítico & $68 \mathrm{aB}$ & $76 \mathrm{bAB}$ & $75 \mathrm{aAB}$ & $78 \mathrm{aA}$ \\
\hline Calcário dolomítico & $67 \mathrm{aB}$ & $80 \mathrm{abA}$ & $72 \mathrm{aAB}$ & $78 \mathrm{aA}$ \\
\hline $\mathrm{CV} \%$ & & & & \\
\hline & & & & \\
\hline Escória & $72 \mathrm{aA}$ & $65 \mathrm{aA}$ & $34 \mathrm{bcB}$ & $23 \mathrm{bcC}$ \\
\hline Silicato de cálcio & $71 \mathrm{aA}$ & 55 abcA & $43 \mathrm{abBC}$ & $47 \mathrm{aC}$ \\
\hline Silicato de cálcio e magnésio & $74 \mathrm{aA}$ & $60 \mathrm{abB}$ & $45 \mathrm{aC}$ & $30 \mathrm{bD}$ \\
\hline Calcário calcítico & $69 \mathrm{aA}$ & $54 \mathrm{bcB}$ & $27 \mathrm{cC}$ & $16 \mathrm{cD}$ \\
\hline Calcário dolomítico & $64 \mathrm{aA}$ & $48 \mathrm{cB}$ & $38 \mathrm{abC}$ & $19 \mathrm{cD}$ \\
\hline $\mathrm{CV} \%$ & & & & \\
\hline
\end{tabular}

Letras maiúsculas correspondem ás comparações entre as granulometrias para o mesmo corretivo de acidez do solo pelo teste de Tukey com nível de significância $(\alpha)$ 0,05. Letras minúsculas correspondem ás comparações entre os corretivos de acidez do solo dentro da mesma granulometria pelo teste de Tukey com nível de significância ( $\alpha$ ) 0,05 
Tabela 9 - Desdobramento das interações corretivos x granulometrias para atributos químicos do Latossolo Vermelho distrófico (LVd) após 60 dias de incubação.

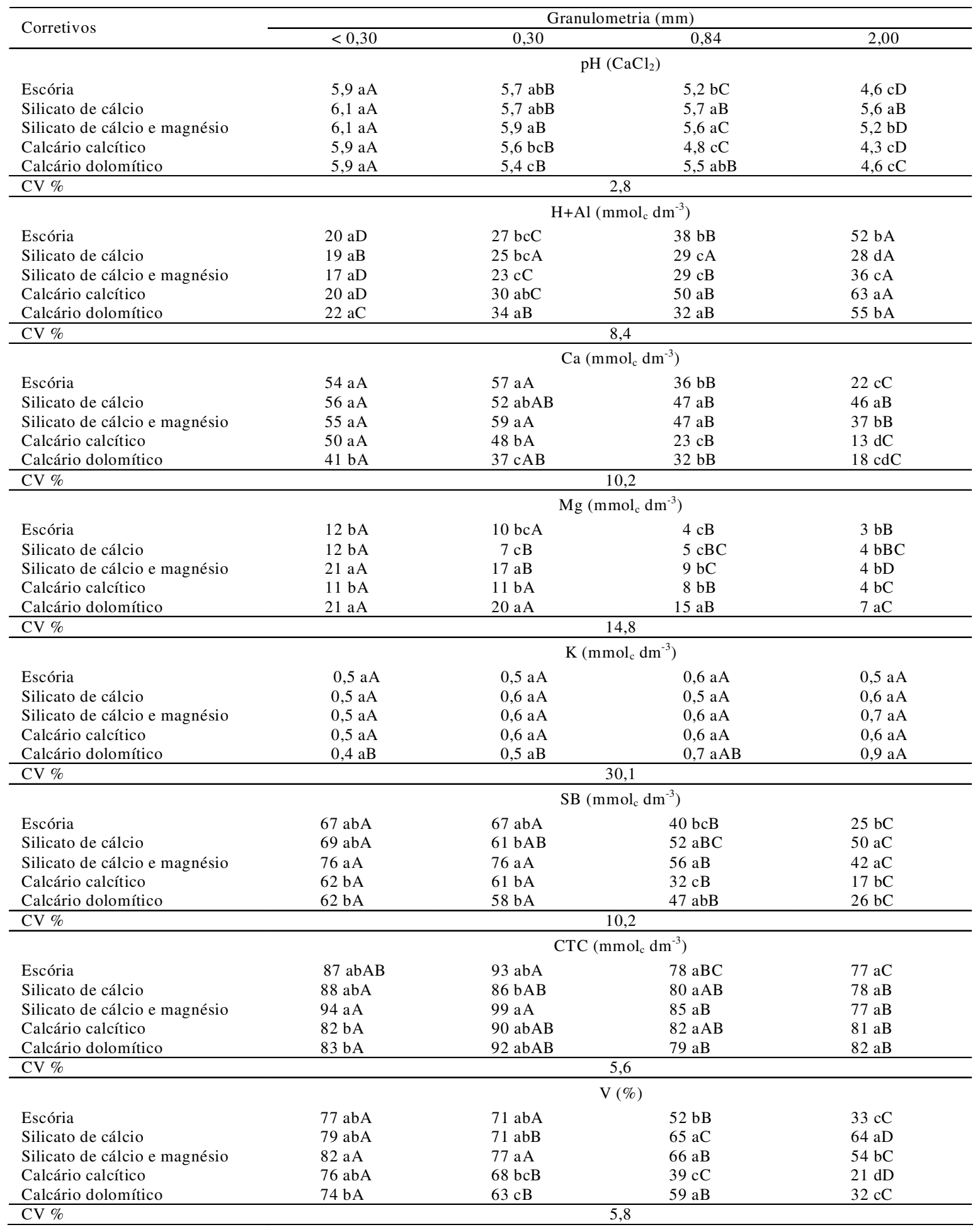

Letras maiúsculas correspondem ás comparações entre as granulometrias para o mesmo corretivo de acidez do solo pelo teste de Tukey com nível de significância $(\alpha)$ 0,05. Letras minúsculas correspondem ás comparações entre os corretivos de acidez do solo dentro da mesma granulometria pelo teste de Tukey com nível de significância $(\alpha) 0,05$. 
Tabela 10 - Desdobramento das interações corretivos x granulometrias para atributos químicos do Latossolo Vermelho distrófico (LVd) após 90 dias de incubação.

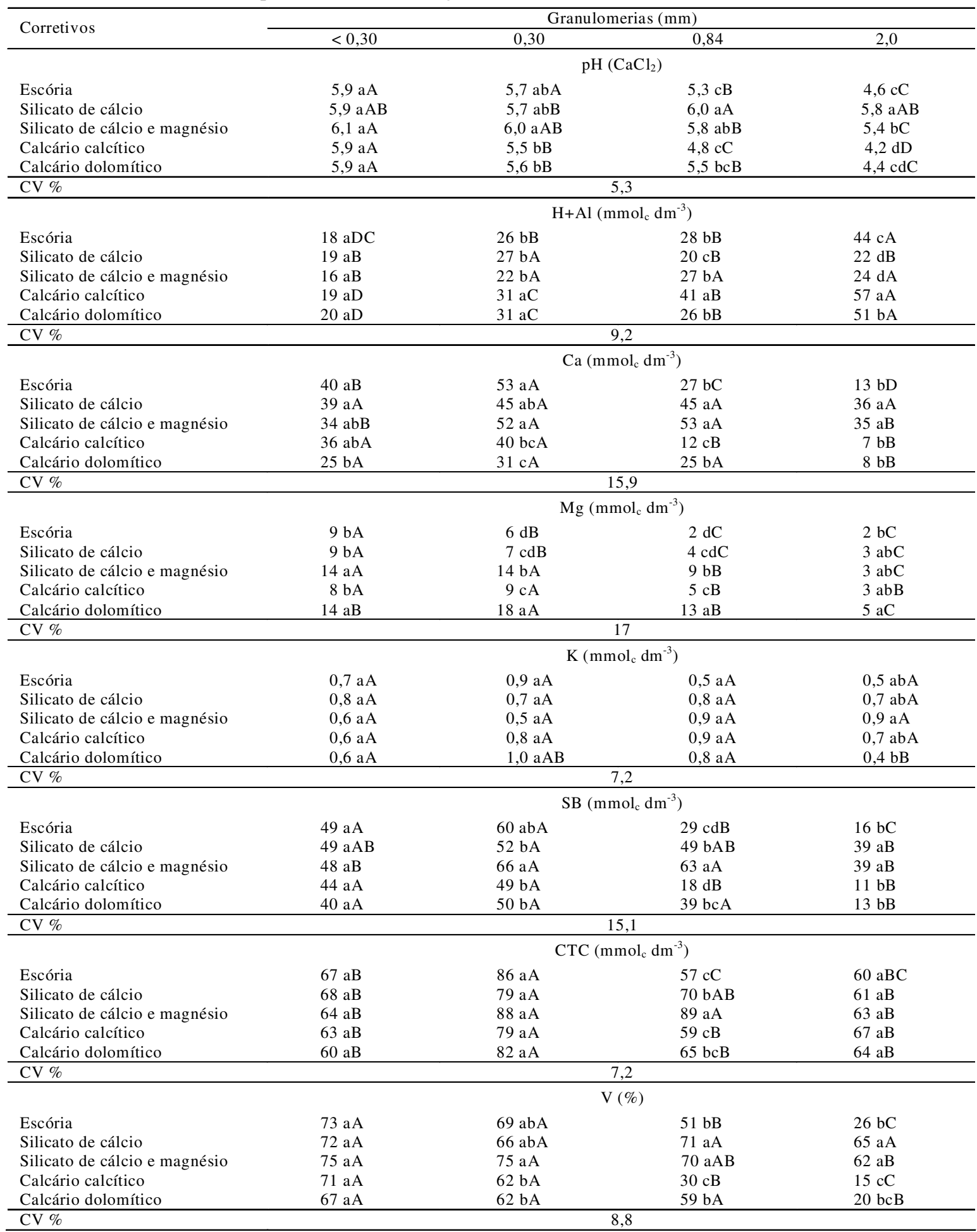

Letras maiúsculas correspondem ás comparações entre as granulometrias para o mesmo corretivo de acidez do solo pelo teste de Tukey com nível de significância $(\alpha)$ 0,05. Letras minúsculas correspondem ás comparações entre os corretivos de acidez do solo dentro da mesma granulometria pelo teste de Tukey com nível de significância $(\alpha) 0,05$. 

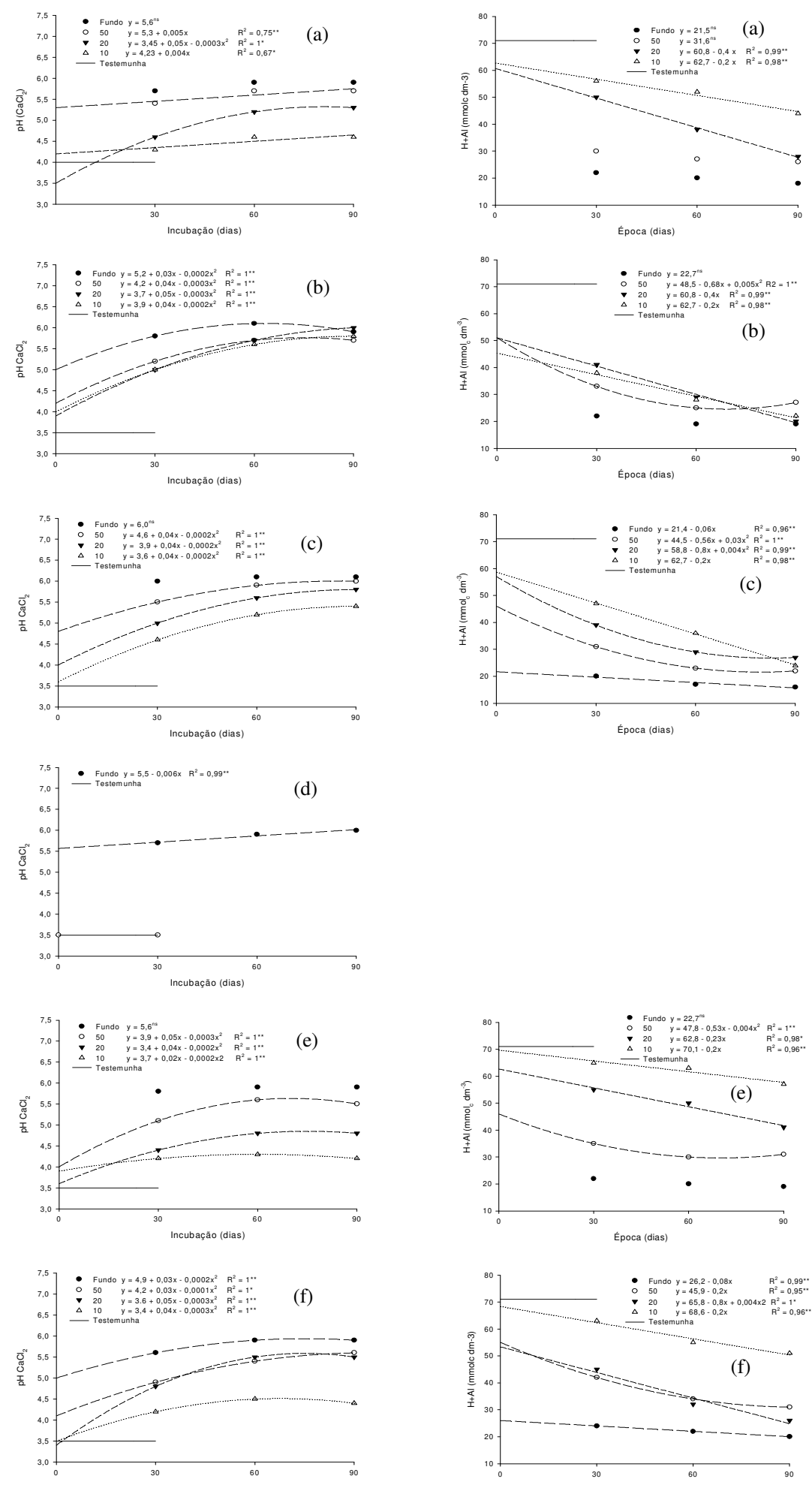

Figura 4. Desdobramento das interações granulometrias (Fundo: $\emptyset<0,30 \mathrm{~mm} ; 50: \emptyset=0,30 \mathrm{~mm} ; 20: \emptyset=0,84 \mathrm{~mm} ; 10: \varnothing=2 \mathrm{~mm}$ ) $\mathrm{x}$ períodos de incubação para valores de $\mathrm{pH}$ e $\mathrm{H}+\mathrm{Al}$ do Latossolo Vermelho distrófico (LVd) com a aplicação de escória (a), silicato de cálcio (b), silicato de cálcio e magnésio (c), wollastonita ${ }^{1}$ (d), calcário calcítico (e) e calcário dolomítico (f).* e ** significativos a 5\% e $1 \%$ de probabilidade, respectivamente. ns- não significativo. ${ }^{1}$ possui apenas a fração granulométrica $<0,30 \mathrm{~mm}$. 


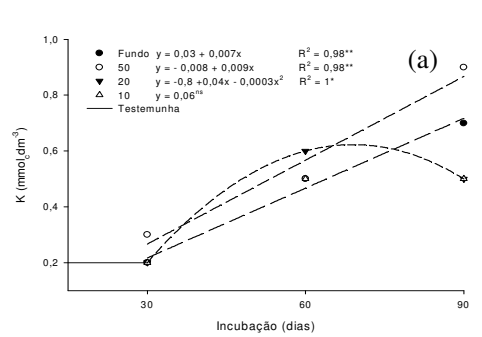

(b)

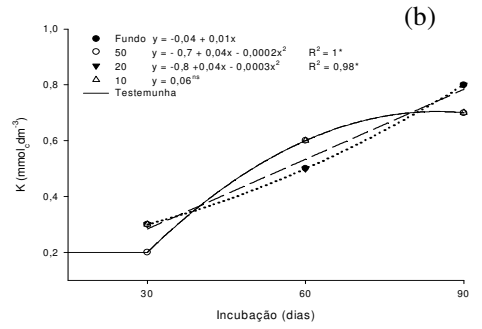

(c)

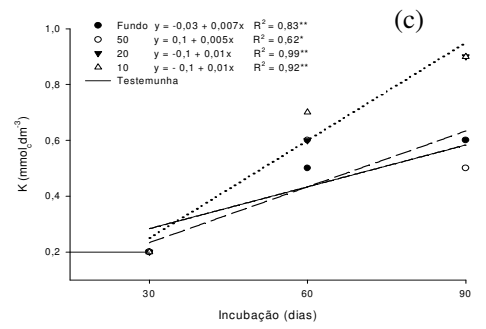

(d);
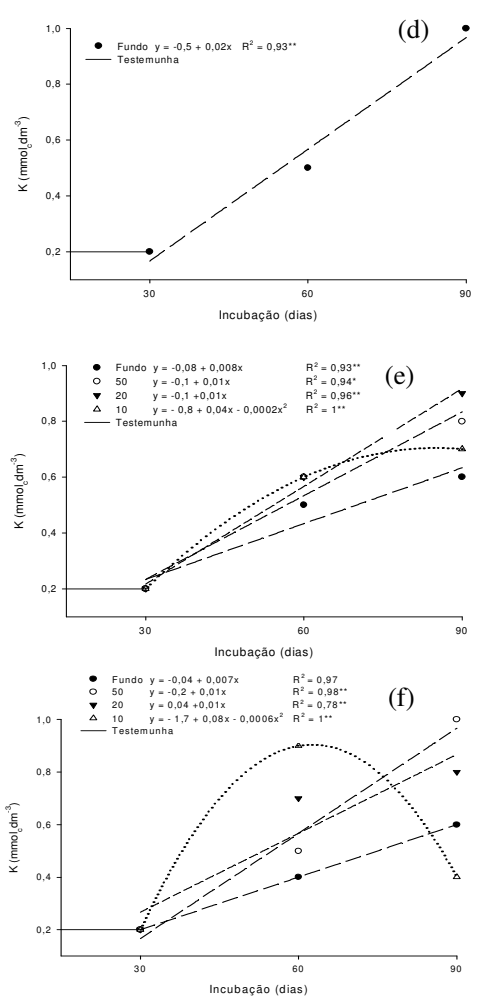

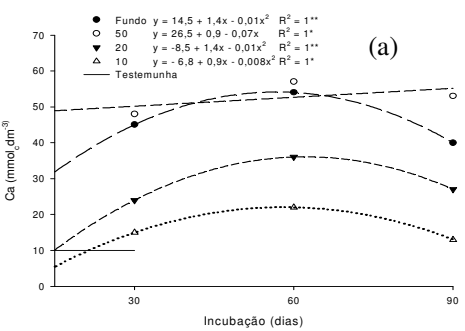

(b)

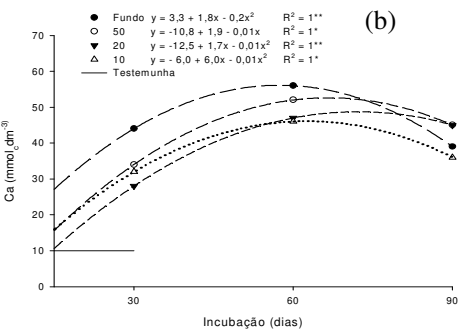

(c)

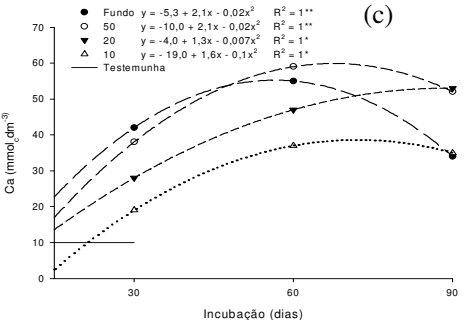

(d)

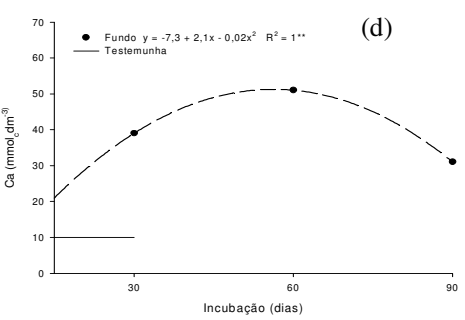

(e)
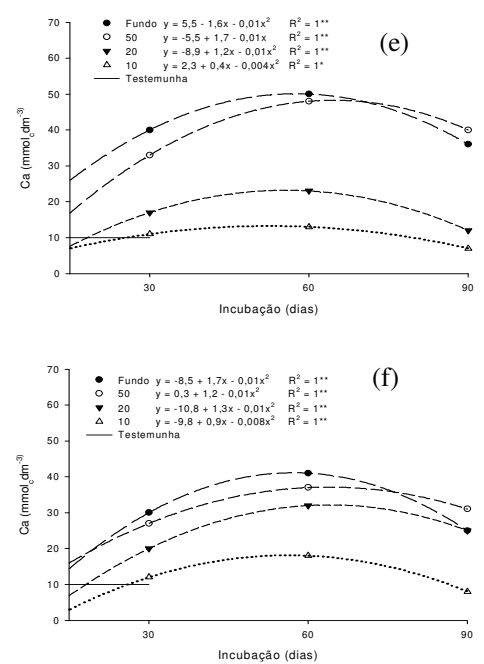

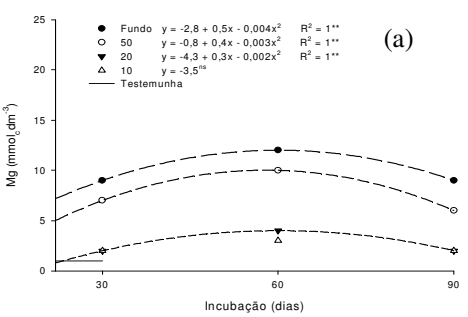

(b)

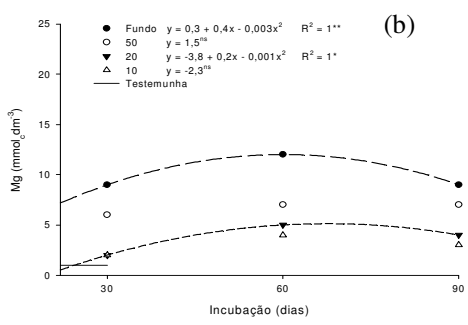

(c)
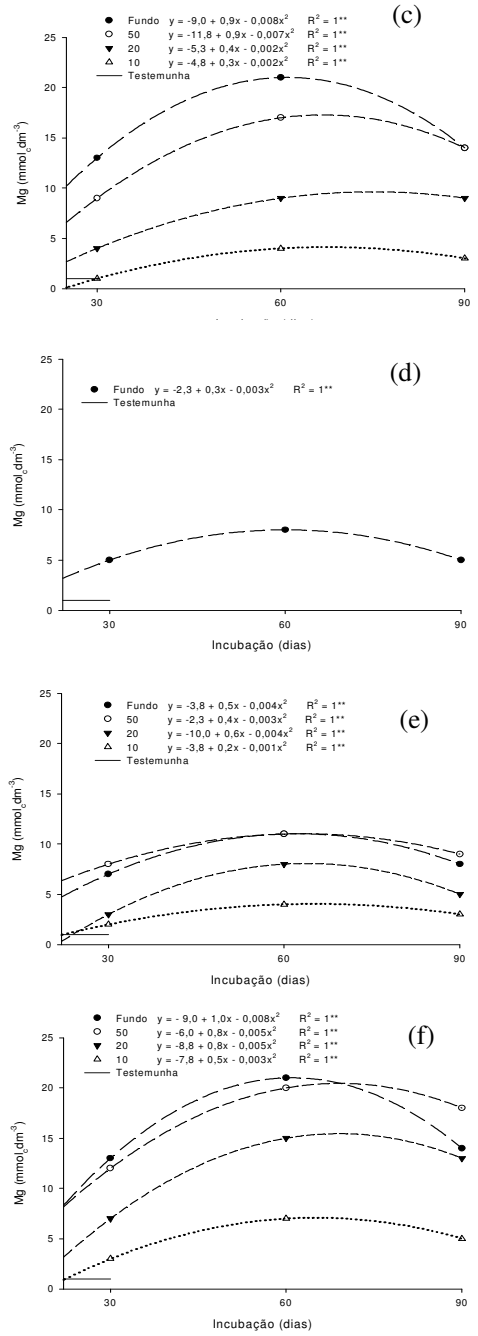

Figura 5. Desdobramento das interações granulometrias (Fundo: $\emptyset<0,30 \mathrm{~mm} ; 50: \emptyset=0,30 \mathrm{~mm} ; 20: \emptyset=0,84 \mathrm{~mm} ; 10: \varnothing=2 \mathrm{~mm}$ ) $\mathrm{x}$ períodos de incubação para teores de K, Ca e Mg do Latossolo Vermelho distrófico (LVd) com a aplicação de escória (a), silicato de cálcio (b), silicato de cálcio e magnésio (c), wollastonita ${ }^{1}$ (d), calcário calcítico (e) e calcário dolomítico (f). * e ** significativos a $5 \%$ e $1 \%$ de probabilidade, respectivamente. ns- não significativo. ${ }^{1}$ possui apenas a fração granulométrica $<0,30 \mathrm{~mm}$. 

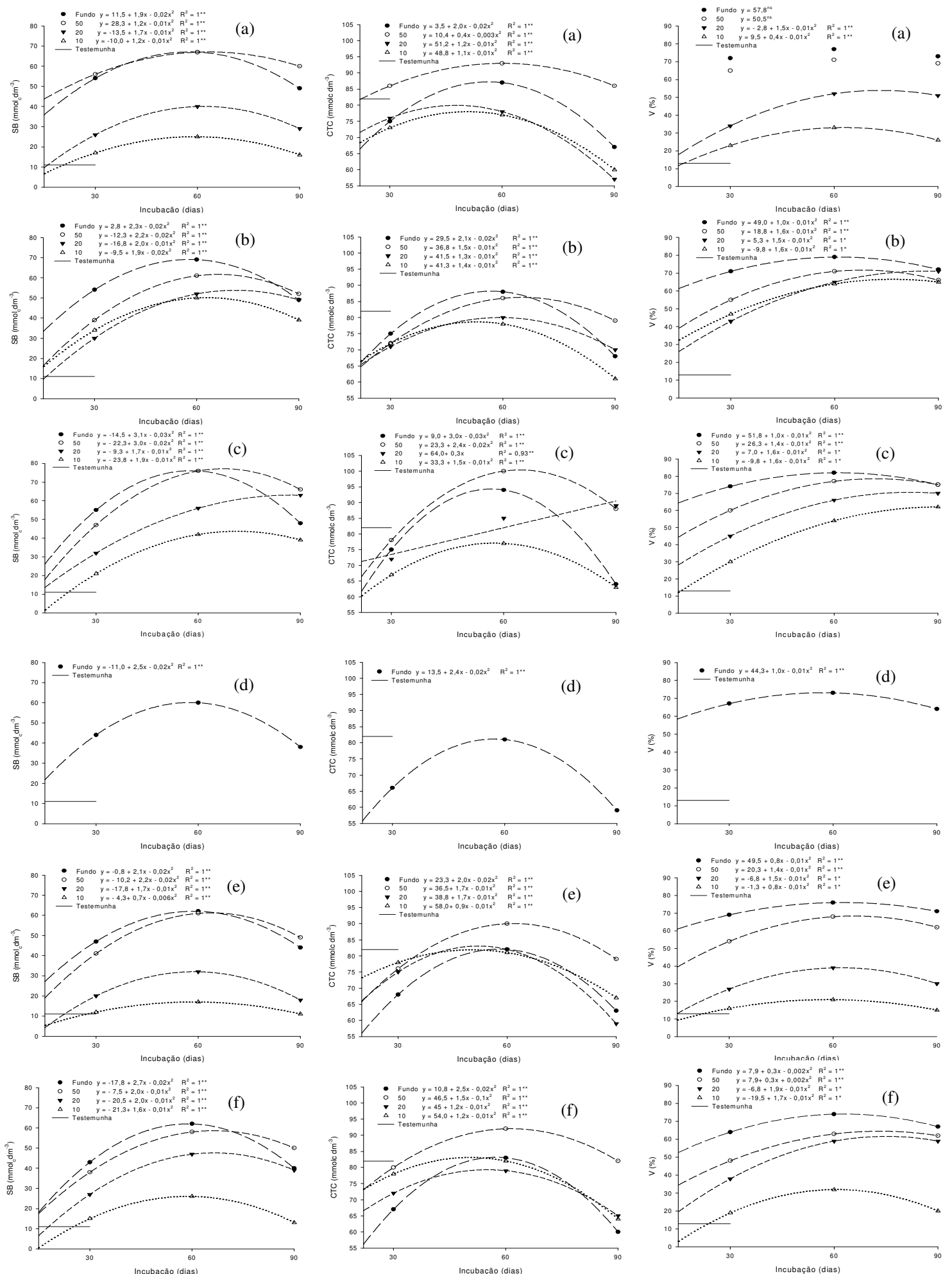

Figura 6. Desdobramento das interações granulometrias (Fundo: $\emptyset<0,30 \mathrm{~mm} ; 50: \varnothing=0,30 \mathrm{~mm} ; 20: \varnothing=0,84 \mathrm{~mm} ; 10: \varnothing=2 \mathrm{~mm}$ ) x períodos de incubação para valores de SB, CTC e V\% do Latossolo Vermelho distrófico (LVd) com a aplicação de escória (a), silicato de cálcio (b), silicato de cálcio e magnésio (c), wollastonita ${ }^{1}$ (d), calcário calcítico (e) e calcário dolomítico (f). ${ }^{*}{ }^{* *}$ significativos a $5 \%$ e $1 \%$ de probabilidade, respectivamente. ns- não significativo. ${ }^{1}$ possui apenas a fração granulométrica $<$ $0,30 \mathrm{~mm}$. 
Os teores de Ca no solo foram elevados, os tratamentos aumentaram bastante o teor deste nutriente no solo que inicialmente era de $8 \mathrm{mmol}_{\mathrm{c}} \mathrm{dm}^{-3}$. O teor de cálcio foi superior com a aplicação da fração granulométrica $<0,30 \mathrm{~mm}$ como já esperado, exceção apenas para o período de incubação de noventa dias, em que a escória na fração granulométrica $0,30 \mathrm{~mm}$ e o silicato de cálcio e magnésio nas frações granulométricas 0,30 mm e 0,84 mm proporcionaram os maiores teores de cálcio, Tabela 10.

Quando as partículas dos corretivos são menores supõe-se que estas disponibilizam maior quantidade de cálcio pelo favorecimento do contato corretivo solo devido a maior superfície especifica e assim maior solubilização. A importância do tempo de solubilização para partículas maiores, como aquelas retidas na peneira 20 e 10 foi destacada por Natale e Coutinho (1994), trabalhando com frações granulométricas de calcários.

O fato das frações granulométricas de $0,30 \mathrm{~mm}$ e $0,84 \mathrm{~mm}$ da escória e do silicato de cálcio e magnésio aos noventa dias de incubação terem disponibilizado maiores teores de cálcio do que partículas $<0,30 \mathrm{~mm}$ pode estar relacionado com as doses aplicadas, já que à medida que aumentava a granulometria a dose aplicada também aumentava, e com o decorrer da incubação estas partículas passaram a se solubilizar, fato que não foi notado nos primeiros dias de incubação. Outro fato é que estas partículas, com o decorrer do tempo, podem ter se subdividido e assim quantificada na análise química, mesmo não estando solubilizada durante o período de incubação.

Os teores de cálcio no solo variaram em função do corretivo dentro de uma mesma granulometria. Na fração granulométrica $<0,30 \mathrm{~mm}$ aos trinta e sessenta dias de incubação apenas o calcário dolomítico diferiu dos demais corretivos, proporcionando o menor teor de cálcio no solo. Nesta mesma granulometria aos 90 dias, o calcário dolomítico permaneceu com os menores teores, mas foi significativamente igual ao silicato de cálcio e ao calcário calcítico.

Para as demais frações granulométricas nos três períodos de avaliação, os maiores teores de cálcio foram obtidos com a aplicação dos silicatos, os quais praticamente não diferiram entre si. Embora muitas vezes a escória e o silicato de cálcio foram estatisticamente iguais, foi a escória que disponibilizou maiores teores de cálcio em todas as frações granulométricas nos três períodos de avaliação (Tabelas 8, 9 e 10). 
O teor de cálcio elevou até sessenta dias de incubação, mas aos noventa dias teve-se decréscimo para todas as frações granulométricas dos corretivos, (Figura $5)$.

Os maiores teores de magnésio foram obtidos com aplicação de calcário dolomítico e silicato de cálcio e magnésio. A aplicação das partículas retidas nas peneiras fundo e 50 (granulometria $<0,30 \mathrm{~mm}$ e $0,30 \mathrm{~mm}$ ) foram as que disponibilizaram maior quantidade de magnésio, estando estas bem próximas e muitas vezes não diferiram significativamente entre si (Tabelas 8, 9 e 10).

Analisando a composição química dos corretivos (Tabela 2), verificase que a escória apresentava em sua composição teor de $\mathrm{MgO}$ muito próximo ao calcário dolomítico e superior ao silicato de cálcio e magnésio, entretanto, analisando os resultados dos teores de magnésio trocável no solo após as incubações (Tabelas 8, 9 e 10) nota-se que a escória não foi eficiente na solubilização do magnésio para a forma trocável. $\mathrm{O}$ mesmo foi observado para o silicato de cálcio, com teor de $\mathrm{MgO}$ superior ao silicato de cálcio e magnésio.

Verifica-se pelo valor inicial de magnésio do solo $\left(1 \mathrm{mmol}_{\mathrm{c}} \mathrm{dm}^{-3}\right)$ (Tabela 1) que a fração granulométrica 2,0 mm (Tabela 8) praticamente não disponibilizou magnésio no período de trinta dias, a partir de sessenta dias é que os acréscimos foram mais significativos, mesmo assim os valores obtidos por essa fração granulométrica ficou bem distante dos valores das demais.

Da mesma maneira que ocorreu para o cálcio, o teor de magnésio elevou até sessenta dias de incubação, mas aos noventa dias houve decréscimo para a maioria das frações granulométricas dos corretivos, (Figura 5).

Para os teores de potássio a interação de granulometrias e corretivos não foi significativa, entretanto, para melhor visualização as médias estão apresentadas nas Tabelas 8, 9 e 10. Todas as frações granulométricas foram pouco eficientes em sua disponibilização, devido à ausência desse nutriente na composição dos corretivos, permanecendo com teores baixos, próximos aos encontrados na condição original dos solos.

A interação granulometrias $\mathrm{x}$ incubação foi significativa para os teores de potássio, embora os acréscimos no teor de potássio foram pequenos este se elevou com o aumento no período de incubação (Figura 5). 
As alterações nos teores de cálcio e magnésio refletiram de forma direta na soma de bases. $\mathrm{O}$ aumento no valor da soma de bases acompanhou a diminuição do tamanho das partículas dos corretivos. Verifica-se que no período de 30 dias a fração granulométrica $<0,30 \mathrm{~mm}$ e a fração granulométrica $0,30 \mathrm{~mm}$ só diferiram na aplicação do silicato de cálcio, para os demais períodos estas frações granulométricas de todos os corretivos foram significativamente iguais no valor de soma de bases.

No período de noventa dias de incubação, os valores da soma de bases obtidos com a aplicação da fração granulométrica $0,84 \mathrm{~mm}$ do silicato de cálcio, silicato de cálcio e magnésio e do calcário dolomítico tendeu a se igualar a granulometria $0,30 \mathrm{~mm}$ e a granulometria $<0,30 \mathrm{~mm}$, mostrando mais uma vez a necessidade de maior tempo de reação para esta fração de maior dimensão.

Assim como ocorreu para os teores de cálcio e magnésio, a soma de base elevou-se no período de trinta a sessenta dias e decresceu aos noventa dias de incubação (Figura 6).

Comparando o valor da CTC inicial do solo $\left(79 \mathrm{mmol}_{\mathrm{c}} \mathrm{dm}^{-3}\right)$ com os valores obtidos após trinta dias da aplicação dos tratamentos (Tabela 8), observa-se que a CTC deste solo não sofreu alteração neste período. No período de sessenta e noventa dias os valores da CTC foram superiores ao inicial do solo, com pequenas exceções na fração granulométrica $0,84 \mathrm{~mm}$ e principalmente na fração granulométrica $2,0 \mathrm{~mm}$.

Para os valores da saturação por bases os tratamentos alteraram o valor inicial já aos trinta dias de incubação. $\mathrm{O}$ valor da saturação por bases aumentou à medida que diminuía o tamanho das partículas (Tabelas 8, 9 e 10), entretanto, com o decorrer do tempo de incubação algumas frações granulométricas tenderam a se igualar.

Os resultados da comparação da wollastonita com os demais corretivos aos 30, 60 e 90 dias de incubação estão na Tabela 11. A wollastonita de maneira geral foi inferior aos demais corretivos principalmente aos silicatos. 
Tabela 11 - Atributos químicos do Latossolo Vermelho distrófico (LVd) em função da aplicação da granulometria $<0,30 \mathrm{~mm}$ (peneira fundo) dos corretivos.

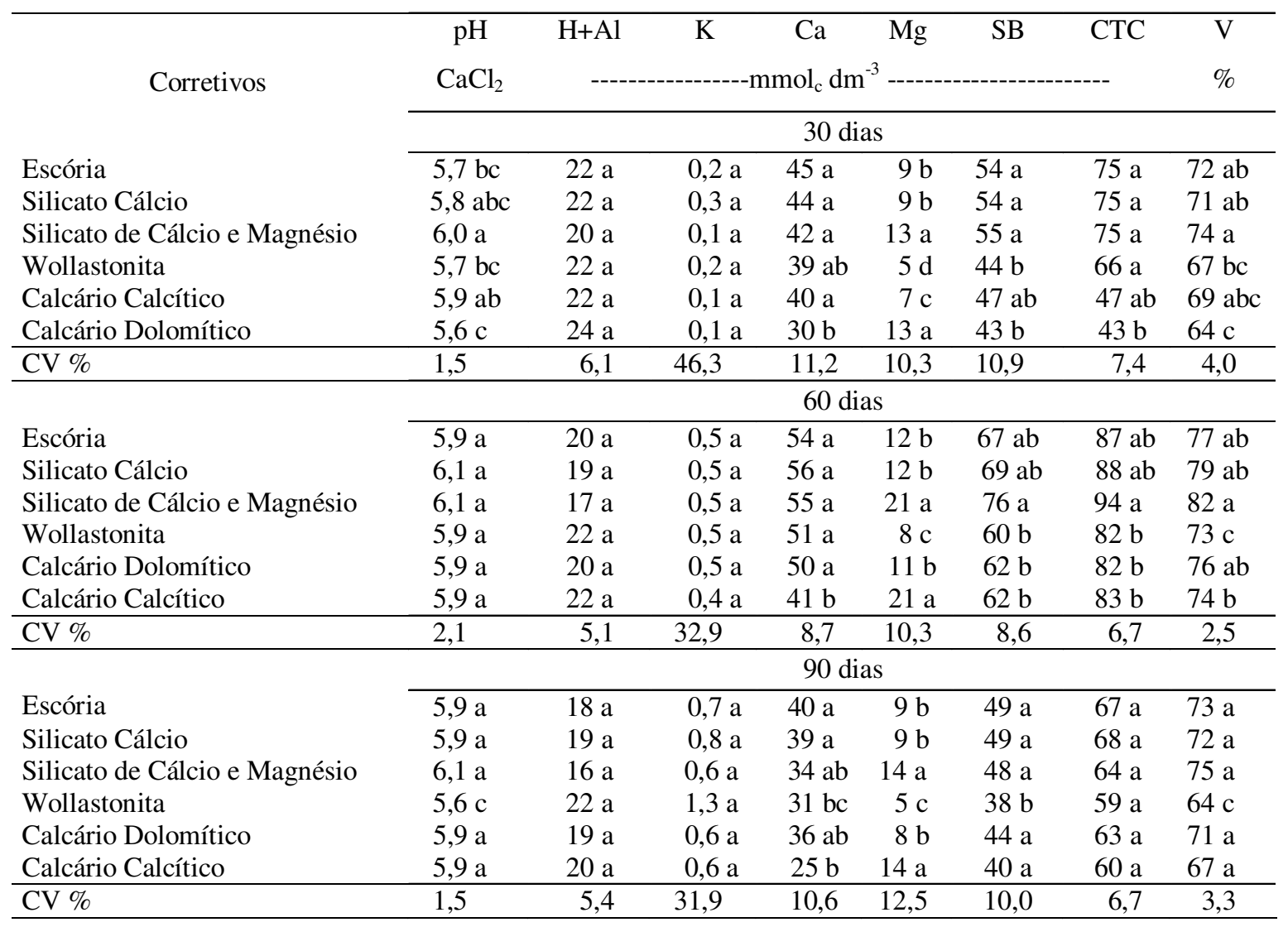

Médias seguidas de mesma letra não diferem entre si pelo teste de Tukey a $5 \%$ de probabilidade.

\subsubsection{Nitossolo Vermelho eutrófico (NVe)}

As interações corretivos x granulometrias aos 30,60 e 90 dias de incubação foram significativas nos atributos químicos do solo exceto, para o potássio. Os desdobramentos estão apresentados nas Tabelas 12, 13 e 14.

Para avaliar a velocidade na neutralização da acidez dos solos pelos corretivos, analisou-se o efeito da granulometria no decorrer dos períodos de incubação. A interação granulometrias x períodos de incubação foi significativa nos valores de $\mathrm{pH}$ e $\mathrm{H}+\mathrm{Al}$ (Figura 7), no teor de cálcio e magnésio (Figura 9) e nos valores de SB, CTC e V\% (Figura 10), exceto para o calcário calcítico. Para o potássio apenas o efeito de períodos de incubação foi significativo, quando aplicado a escória e os calcários dolomítico e calcítico (Figura 8). 
Tabela 12-Desdobramento das interações corretivos x granulometrias para atributos químicos do Nitossolo Vermelho eutrófico (NVe) após 30 dias de incubação.

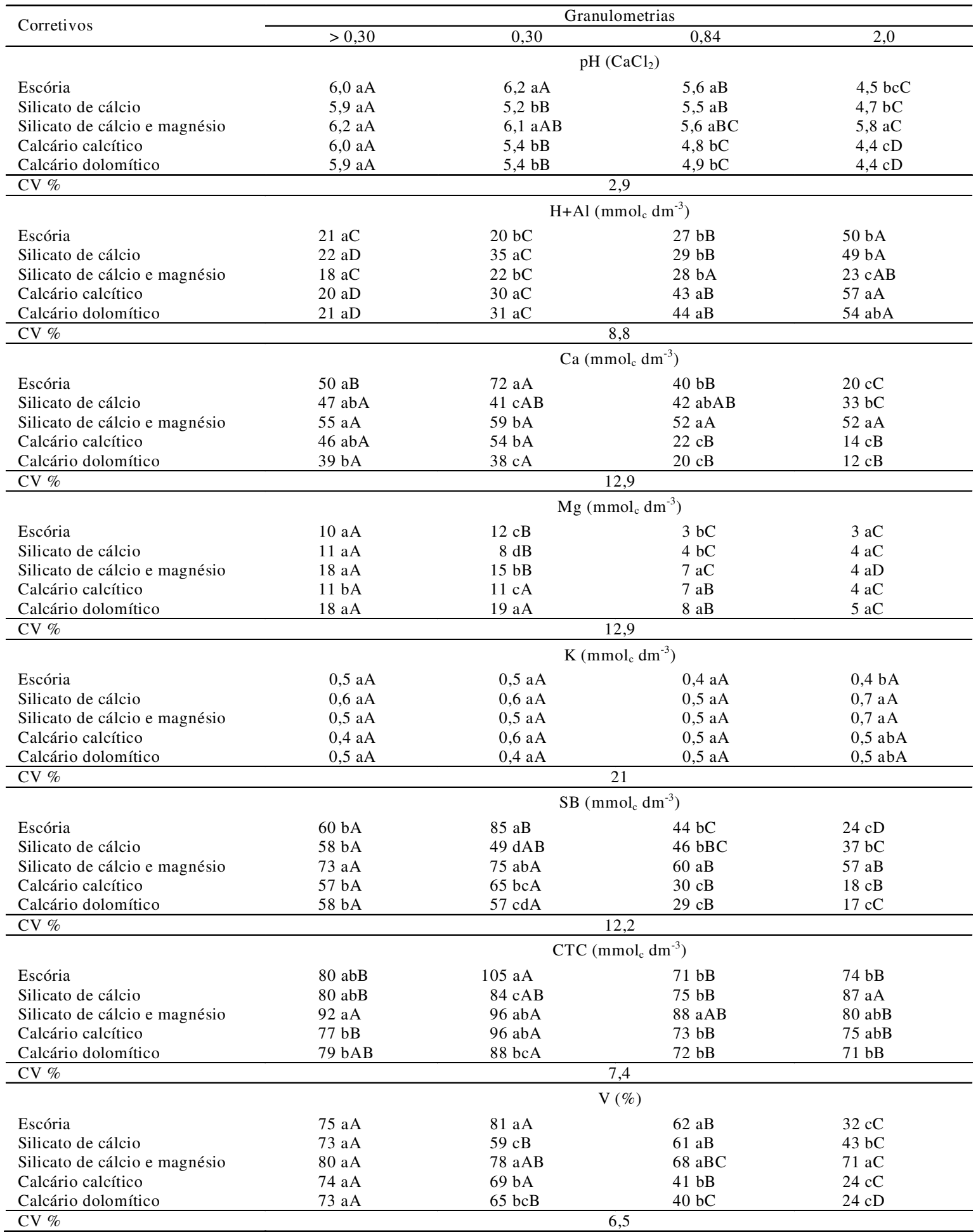

Letras maiúsculas correspondem ás comparações entre as granulometrias para o mesmo corretivo de acidez do solo pelo teste de Tukey com nível de significância $(\alpha)$ 0,05. Letras minúsculas correspondem ás comparações entre os corretivos de acidez do solo dentro da mesma granulometria pelo teste de Tukey com nível de significância $(\alpha) 0,05$. 
Tabela 13-Desdobramento das interações corretivos x granulometrias para atributos químicos do Nitossolo Vermelho eutrófico (NVe) após 60 dias de incubação.

\begin{tabular}{|c|c|c|c|c|}
\hline \multirow{2}{*}{ Corretivos } & \multicolumn{4}{|c|}{ Granulometrias (mm) } \\
\hline & $>0,30$ & 0,30 & 0,84 & 2,00 \\
\hline & \multicolumn{4}{|c|}{$\mathrm{pH}\left(\mathrm{CaCl}_{2}\right)$} \\
\hline Escória & $6,4 \mathrm{aA}$ & $6,8 \mathrm{aA}$ & $6,4 \mathrm{aA}$ & $5,0 \mathrm{bcB}$ \\
\hline Silicato de cálcio & $6,3 \mathrm{aA}$ & $5,9 \mathrm{cB}$ & $6,4 \mathrm{aA}$ & $5,3 \mathrm{bC}$ \\
\hline Silicato de cálcio e magnésio & $6,4 \mathrm{aA}$ & $6,6 \mathrm{abA}$ & $6,5 \mathrm{aA}$ & $6,7 \mathrm{aA}$ \\
\hline Calcário calcítico & $6,5 \mathrm{aA}$ & $6,2 \mathrm{bcA}$ & $5,4 \mathrm{bB}$ & $4,7 \mathrm{cC}$ \\
\hline Calcário dolomítico & $6,3 \mathrm{aA}$ & $6,3 \mathrm{abA}$ & $5,5 \mathrm{bB}$ & $4,8 \mathrm{cC}$ \\
\hline \multirow[t]{2}{*}{$\mathrm{CV} \%$} & \multicolumn{4}{|c|}{3,4} \\
\hline & \multicolumn{4}{|c|}{$\mathrm{H}+\mathrm{Al}\left(\mathrm{mmol}_{\mathrm{c}} \mathrm{dm}^{-3}\right)$} \\
\hline Escória & $24 \mathrm{aB}$ & $18 \mathrm{cC}$ & $22 \mathrm{bBC}$ & $44 \mathrm{bA}$ \\
\hline Silicato de cálcio & $24 \mathrm{aC}$ & $31 \mathrm{aB}$ & $22 \mathrm{bC}$ & $40 \mathrm{bA}$ \\
\hline Silicato de cálcio e magnésio & $21 \mathrm{aA}$ & $20 \mathrm{bcA}$ & $20 \mathrm{bA}$ & $20 \mathrm{cA}$ \\
\hline Calcário calcítico & $22 \mathrm{aC}$ & $26 \mathrm{abC}$ & $40 \mathrm{aB}$ & $54 \mathrm{aA}$ \\
\hline Calcário dolomítico & $23 \mathrm{aC}$ & $26 \mathrm{abC}$ & $40 \mathrm{aB}$ & $52 \mathrm{aA}$ \\
\hline \multirow[t]{2}{*}{$\mathrm{CV} \%$} & \multicolumn{4}{|c|}{10,5} \\
\hline & \multicolumn{4}{|c|}{$\mathrm{Ca}\left(\mathrm{mmol}_{\mathrm{c}} \mathrm{dm}^{-3}\right)$} \\
\hline Escória & $59 \mathrm{aBC}$ & $103 \mathrm{aA}$ & $68 \mathrm{aB}$ & $33 \mathrm{bC}$ \\
\hline Silicato de cálcio & $55 \mathrm{aAB}$ & $52 \mathrm{bAB}$ & $75 \mathrm{aA}$ & $35 \mathrm{bB}$ \\
\hline Silicato de cálcio e magnésio & $54 \mathrm{aA}$ & $72 \mathrm{bA}$ & $70 \mathrm{aA}$ & $72 \mathrm{aA}$ \\
\hline Calcário calcítico & $54 \mathrm{aA}$ & $52 \mathrm{bA}$ & $53 \mathrm{abA}$ & $18 \mathrm{bB}$ \\
\hline Calcário dolomítico & $40 \mathrm{aA}$ & $47 \mathrm{bA}$ & $26 \mathrm{bAB}$ & $10 \mathrm{bB}$ \\
\hline \multirow[t]{2}{*}{$\mathrm{CV} \%$} & \multicolumn{4}{|c|}{33,6} \\
\hline & \multicolumn{4}{|c|}{$\mathrm{Mg}\left(\mathrm{mmol}_{\mathrm{c}} \mathrm{dm}^{-3}\right)$} \\
\hline Escória & $14 \mathrm{aB}$ & $25 \mathrm{aA}$ & $5 \mathrm{bB}$ & $5 \mathrm{aB}$ \\
\hline Silicato de cálcio & $13 \mathrm{aA}$ & $10 \mathrm{cA}$ & $5 \mathrm{bA}$ & $5 \mathrm{aA}$ \\
\hline Silicato de cálcio e magnésio & $21 \mathrm{aA}$ & $21 \mathrm{abA}$ & $12 \mathrm{abAB}$ & $4 \mathrm{aB}$ \\
\hline Calcário calcítico & $13 \mathrm{aAB}$ & $14 \mathrm{bcAB}$ & $21 \mathrm{aA}$ & $8 \mathrm{aB}$ \\
\hline Calcário dolomítico & $23 \mathrm{aAB}$ & $28 \mathrm{aA}$ & $16 \mathrm{aBC}$ & $8 \mathrm{aC}$ \\
\hline \multirow[t]{2}{*}{$\mathrm{CV} \%$} & \multicolumn{4}{|c|}{41,9} \\
\hline & \multicolumn{4}{|c|}{$\mathrm{K}\left(\mathrm{mmol}_{\mathrm{c}} \mathrm{dm}^{-3}\right)$} \\
\hline Escória & $0,4 \mathrm{aA}$ & $0,6 \mathrm{aA}$ & $0,4 \mathrm{aA}$ & $0,7 \mathrm{aA}$ \\
\hline Silicato de cálcio & $0,8 \mathrm{aA}$ & $0,5 \mathrm{aA}$ & $0,5 \mathrm{aA}$ & $0,6 \mathrm{aA}$ \\
\hline Silicato de cálcio e magnésio & $0,6 \mathrm{aA}$ & $0,5 \mathrm{aA}$ & $0,7 \mathrm{aA}$ & $0,5 \mathrm{aA}$ \\
\hline Calcário calcítico & $0,4 \mathrm{aA}$ & $0,4 \mathrm{aA}$ & $0,4 \mathrm{aA}$ & $0,5 \mathrm{aA}$ \\
\hline Calcário dolomítico & $0,6 \mathrm{aA}$ & $0,6 \mathrm{aA}$ & $0,4 \mathrm{aA}$ & $0,6 \mathrm{aA}$ \\
\hline \multirow[t]{2}{*}{$\mathrm{CV} \%$} & \multicolumn{4}{|c|}{40} \\
\hline & \multicolumn{4}{|c|}{$\mathrm{SB}\left(\mathrm{mmol}_{\mathrm{c}} \mathrm{dm}^{-3}\right)$} \\
\hline Escória & $74 \mathrm{aB}$ & $160 \mathrm{aA}$ & $74 \mathrm{aB}$ & $38 \mathrm{abB}$ \\
\hline Silicato de cálcio & $69 \mathrm{aA}$ & $63 \mathrm{bA}$ & $80 \mathrm{aA}$ & $39 \mathrm{abA}$ \\
\hline Silicato de cálcio e magnésio & $76 \mathrm{aA}$ & $94 \mathrm{bA}$ & $82 \mathrm{aA}$ & $77 \mathrm{aA}$ \\
\hline Calcário calcítico & $67 \mathrm{aAB}$ & $67 \mathrm{bAB}$ & $74 \mathrm{aA}$ & $26 \mathrm{bB}$ \\
\hline Calcário dolomítico & $63 \mathrm{aA}$ & $76 \mathrm{bA}$ & $43 \mathrm{aAB}$ & $19 \mathrm{bB}$ \\
\hline $\mathrm{CV} \%$ & & & & \\
\hline & & & $\left.\mathrm{m}^{-3}\right)$ & \\
\hline Escória & $98 \mathrm{aB}$ & $179 \mathrm{aA}$ & $96 \mathrm{aB}$ & $82 \mathrm{aB}$ \\
\hline Silicato de cálcio & $93 \mathrm{aA}$ & $93 \mathrm{bA}$ & $101 \mathrm{aA}$ & $79 \mathrm{aA}$ \\
\hline Silicato de cálcio e magnésio & $97 \mathrm{aA}$ & $114 \mathrm{bA}$ & $102 \mathrm{aA}$ & $96 \mathrm{aA}$ \\
\hline Calcário calcítico & $89 \mathrm{aA}$ & $93 \mathrm{bA}$ & $113 \mathrm{aA}$ & $80 \mathrm{aA}$ \\
\hline Calcário dolomítico & $86 \mathrm{aA}$ & $102 \mathrm{bA}$ & $83 \mathrm{aA}$ & $70 \mathrm{aA}$ \\
\hline $\mathrm{CV} \%$ & & & & \\
\hline & & & & \\
\hline Escória & $76 \mathrm{aB}$ & $89 \mathrm{aA}$ & $77 \mathrm{aB}$ & $47 \mathrm{bC}$ \\
\hline Silicato de cálcio & $74 \mathrm{aAB}$ & $67 \mathrm{cB}$ & $79 \mathrm{aA}$ & $49 \mathrm{bC}$ \\
\hline Silicato de cálcio e magnésio & $78 \mathrm{aA}$ & $82 \mathrm{abA}$ & $80 \mathrm{aA}$ & $80 \mathrm{aA}$ \\
\hline Calcário calcítico & $76 \mathrm{aA}$ & $72 \mathrm{bcA}$ & $58 \mathrm{bB}$ & $32 \mathrm{cC}$ \\
\hline Calcário dolomítico & $73 \mathrm{aA}$ & $75 \mathrm{bcA}$ & $51 \mathrm{bB}$ & $26 \mathrm{cC}$ \\
\hline
\end{tabular}

Letras maiúsculas correspondem ás comparações entre as granulometrias para o mesmo corretivo de acidez do solo pelo teste de Tukey com nível de significância $(\alpha)$ 0,05. Letras minúsculas correspondem ás comparações entre os corretivos de acidez do solo dentro da mesma granulometria pelo teste de Tukey com nível de significância ( $\alpha$ ) 0,05. 
Tabela 14-Desdobramento das interações corretivos x granulometrias para atributos químicos do Nitossolo Vermelho eutrófico (NVe) após 90 dias de incubação.

\begin{tabular}{|c|c|c|c|c|}
\hline \multirow{2}{*}{ Corretivos } & \multicolumn{4}{|c|}{ Granulometrias (mm) } \\
\hline & $<0,30$ & 0,30 & 0,84 & $>2,00$ \\
\hline & \multicolumn{4}{|c|}{$\mathrm{pH}\left(\mathrm{CaCl}_{2}\right)$} \\
\hline Escória & $6,0 \mathrm{aB}$ & $6,5 \mathrm{aA}$ & $6,7 \mathrm{aA}$ & $5,1 \mathrm{cC}$ \\
\hline Silicato de cálcio & $5,8 \mathrm{aB}$ & $5,4 \mathrm{cB}$ & 6,6 aA & $5,7 \mathrm{bB}$ \\
\hline Silicato de cálcio e magnésio & $6,0 \mathrm{aC}$ & $6,2 \mathrm{abBC}$ & $6,4 \mathrm{aAB}$ & $6,8 \mathrm{aA}$ \\
\hline Calcário calcítico & $6,1 \mathrm{aA}$ & $5,9 \mathrm{bB}$ & $5,6 \mathrm{bC}$ & $4,6 \mathrm{dD}$ \\
\hline Calcário dolomítico & $5,9 \mathrm{aA}$ & $5,9 \mathrm{bA}$ & $5,6 \mathrm{bA}$ & $4,5 \mathrm{~dB}$ \\
\hline $\mathrm{CV} \%$ & \multicolumn{4}{|c|}{$\mathrm{H}+\mathrm{Al}\left(\mathrm{mmol}_{\mathrm{c}} \mathrm{dm}^{-3}\right)$} \\
\hline Escória & $18 \mathrm{aB}$ & $14 \mathrm{cB}$ & $13 \mathrm{bB}$ & $35 \mathrm{bA}$ \\
\hline Silicato de cálcio & $19 \mathrm{aB}$ & $27 \mathrm{aA}$ & $13 \mathrm{bC}$ & $26 \mathrm{cA}$ \\
\hline Silicato de cálcio e magnésio & $20 \mathrm{aA}$ & $17 \mathrm{bcA}$ & $15 \mathrm{bAB}$ & $11 \mathrm{~dB}$ \\
\hline Calcário calcítico & $17 \mathrm{aC}$ & $21 \mathrm{abC}$ & $28 \mathrm{aB}$ & $45 \mathrm{aA}$ \\
\hline Calcário dolomítico & $20 \mathrm{aC}$ & $21 \mathrm{abC}$ & $27 \mathrm{aB}$ & $43 \mathrm{aA}$ \\
\hline $\mathrm{CV} \%$ & \multicolumn{4}{|c|}{$\mathrm{Ca}\left(\mathrm{mmol}_{\mathrm{c}} \mathrm{dm}^{-3}\right)$} \\
\hline Silicato de cálcio & $46 \mathrm{aB}$ & $43 \mathrm{aB}$ & $83 \mathrm{aA}$ & $45 \mathrm{bB}$ \\
\hline Silicato de cálcio e magnésio & $46 \mathrm{aC}$ & $55 \mathrm{aBC}$ & $68 \mathrm{aB}$ & $98 \mathrm{aA}$ \\
\hline Calcário calcítico & $45 \mathrm{aA}$ & $43 \mathrm{aA}$ & $29 \mathrm{bAB}$ & $15 \mathrm{cB}$ \\
\hline Calcário dolomítico & $36 \mathrm{aA}$ & $38 \mathrm{aA}$ & $31 \mathrm{bAB}$ & $15 \mathrm{cB}$ \\
\hline \multirow[t]{2}{*}{$\mathrm{CV} \%$} & \multicolumn{4}{|c|}{19,1} \\
\hline & \multicolumn{4}{|c|}{$\mathrm{Mg}\left(\mathrm{mmol}_{\mathrm{c}} \mathrm{dm}^{-3}\right)$} \\
\hline Escória & $10 \mathrm{bA}$ & $7 \mathrm{cA}$ & $4 \mathrm{cB}$ & $3 \mathrm{cB}$ \\
\hline Silicato de cálcio & $9 \mathrm{bA}$ & $6 \mathrm{cB}$ & $6 \mathrm{cB}$ & $4 \mathrm{bcB}$ \\
\hline Silicato de cálcio e magnésio & $14 \mathrm{aA}$ & $13 \mathrm{bA}$ & $11 \mathrm{bB}$ & $6 \mathrm{abcC}$ \\
\hline Calcário calcítico & $9 \mathrm{bAB}$ & $11 \mathrm{bA}$ & $12 \mathrm{bA}$ & $7 \mathrm{abB}$ \\
\hline Calcário dolomítico & $16 \mathrm{aA}$ & $19 \mathrm{aA}$ & $17 \mathrm{aA}$ & $9 \mathrm{aB}$ \\
\hline $\mathrm{CV} \%$ & \multicolumn{4}{|c|}{16,0} \\
\hline \multirow[t]{2}{*}{$\mathrm{CV} \%$} & \multicolumn{4}{|c|}{31,3} \\
\hline & \multicolumn{4}{|c|}{$\mathrm{SB}\left(\mathrm{mmol}_{\mathrm{c}} \mathrm{dm}^{-3}\right)$} \\
\hline Escória & $62 \mathrm{aB}$ & $92 \mathrm{aA}$ & $81 \mathrm{aA}$ & $33 \mathrm{bcC}$ \\
\hline Silicato de cálcio & $55 \mathrm{aB}$ & $49 \mathrm{cB}$ & $90 \mathrm{aA}$ & $50 \mathrm{bB}$ \\
\hline Silicato de cálcio e magnésio & $60 \mathrm{aB}$ & $69 \mathrm{bB}$ & $78 \mathrm{aB}$ & $104 \mathrm{aA}$ \\
\hline Calcário calcítico & $54 \mathrm{aA}$ & $54 \mathrm{bcA}$ & $42 \mathrm{bA}$ & $23 \mathrm{cB}$ \\
\hline Calcário dolomítico & $52 \mathrm{aA}$ & $57 \mathrm{bcA}$ & $49 \mathrm{bA}$ & $24 \mathrm{cB}$ \\
\hline $\mathrm{CV} \%$ & & & & \\
\hline & & $\mathrm{CT}$ & $\left.n^{-3}\right)$ & \\
\hline Escória & $80 \mathrm{aBC}$ & $105 \mathrm{aA}$ & $94 \mathrm{aAB}$ & $68 \mathrm{bC}$ \\
\hline Silicato de cálcio & $75 \mathrm{aB}$ & $75 \mathrm{bB}$ & $102 \mathrm{aA}$ & $76 \mathrm{bB}$ \\
\hline Silicato de cálcio e magnésio & $80 \mathrm{aB}$ & $86 \mathrm{bB}$ & $94 \mathrm{aB}$ & $115 \mathrm{aA}$ \\
\hline Calcário calcítico & $71 \mathrm{aA}$ & $75 \mathrm{bA}$ & $70 \mathrm{bA}$ & $68 \mathrm{bA}$ \\
\hline Calcário dolomítico & $72 \mathrm{aA}$ & $78 \mathrm{bA}$ & $76 \mathrm{bA}$ & $67 \mathrm{bA}$ \\
\hline $\mathrm{CV} \%$ & & & & \\
\hline & & & & \\
\hline Escória & $77 \mathrm{aB}$ & $87 \mathrm{aA}$ & $86 \mathrm{aAB}$ & $49 \mathrm{cC}$ \\
\hline Silicato de cálcio & $74 \mathrm{aB}$ & $65 \mathrm{cC}$ & $87 \mathrm{aA}$ & $66 \mathrm{bBC}$ \\
\hline Silicato de cálcio e magnésio & $76 \mathrm{aB}$ & $80 \mathrm{abB}$ & $83 \mathrm{aAB}$ & $90 \mathrm{aA}$ \\
\hline Calcário calcítico & $76 \mathrm{aA}$ & $72 \mathrm{bcA}$ & $59 \mathrm{bB}$ & $34 \mathrm{dC}$ \\
\hline Calcário dolomítico & $73 \mathrm{aA}$ & $73 \mathrm{bcA}$ & $64 \mathrm{bB}$ & $36 \mathrm{dC}$ \\
\hline $\mathrm{CV} \%$ & & & & \\
\hline
\end{tabular}

Letras maiúsculas correspondem ás comparações entre as granulometrias para o mesmo corretivo de acidez do solo pelo teste de Tukey com nível de significância $(\alpha)$ 0,05. Letras minúsculas correspondem ás comparações entre os corretivos de acidez do solo dentro da mesma granulometria pelo teste de Tukey com nível de significância $(\alpha) 0,05$. 

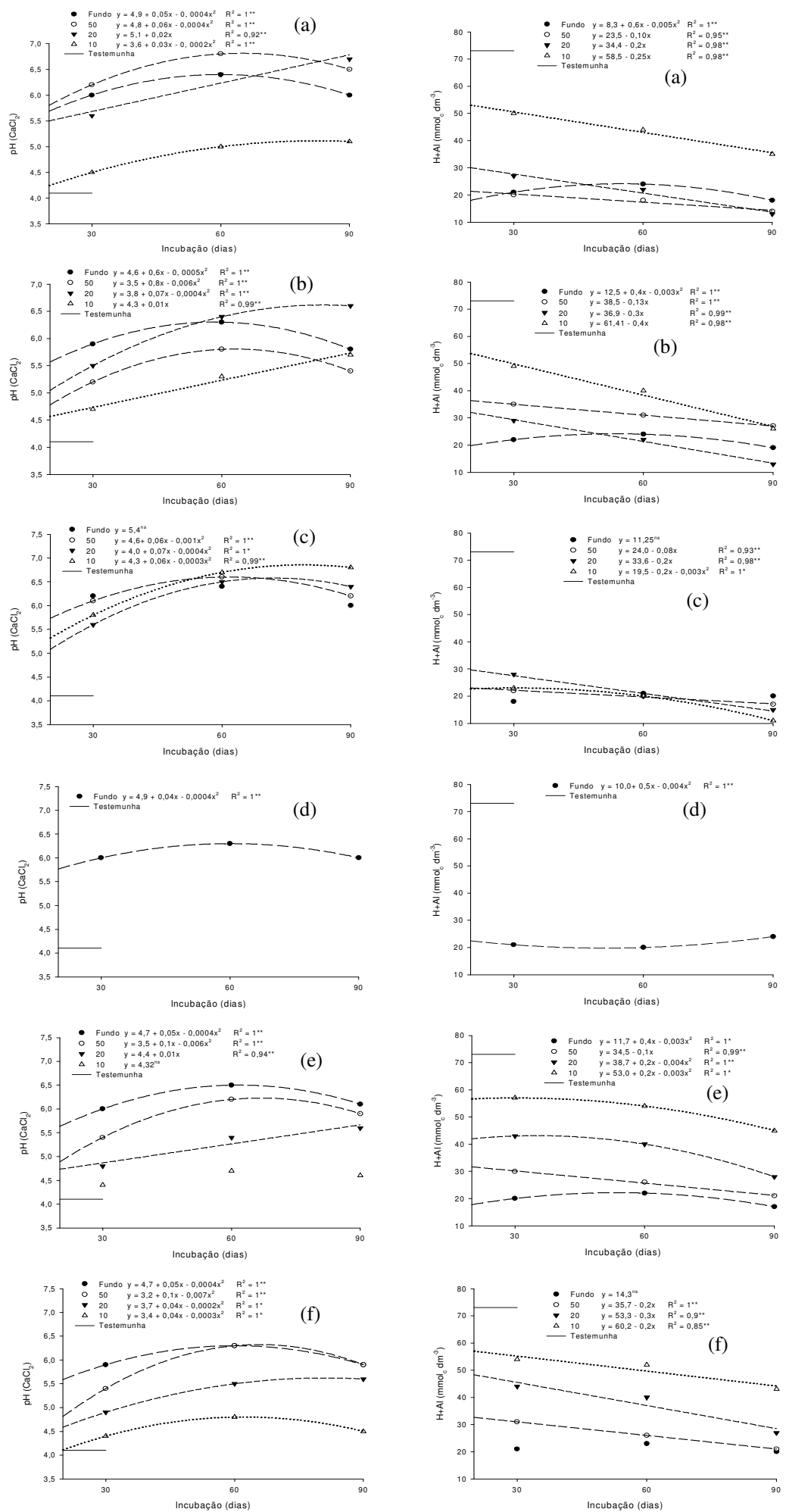

Figura 7. Desdobramento das interações granulometrias (Fundo: $\varnothing<0,30 \mathrm{~mm} ; 50: \varnothing=0,30 \mathrm{~mm} ; 20: \varnothing=0,84 \mathrm{~mm} ; 10$ : $\varnothing=2 \mathrm{~mm}$ ) x períodos de incubação para valores de $\mathrm{pH}$ e $\mathrm{H}+\mathrm{Al}$ do Nitossolo Vermelho eutrófico (NVe) com a aplicação de escória (a), silicato de cálcio (b), silicato de cálcio e magnésio (c), wollastonita ${ }^{1}$ (d), calcário calcítico (e) e calcário dolomítico (f). ${ }^{*} \mathrm{e}^{* *}$ significativos a $5 \%$ e $1 \%$ de probabilidade, respectivamente. ns- não significativo. ${ }^{1}$ possui apenas a fração granulométrica $<0,30 \mathrm{~mm}$. 

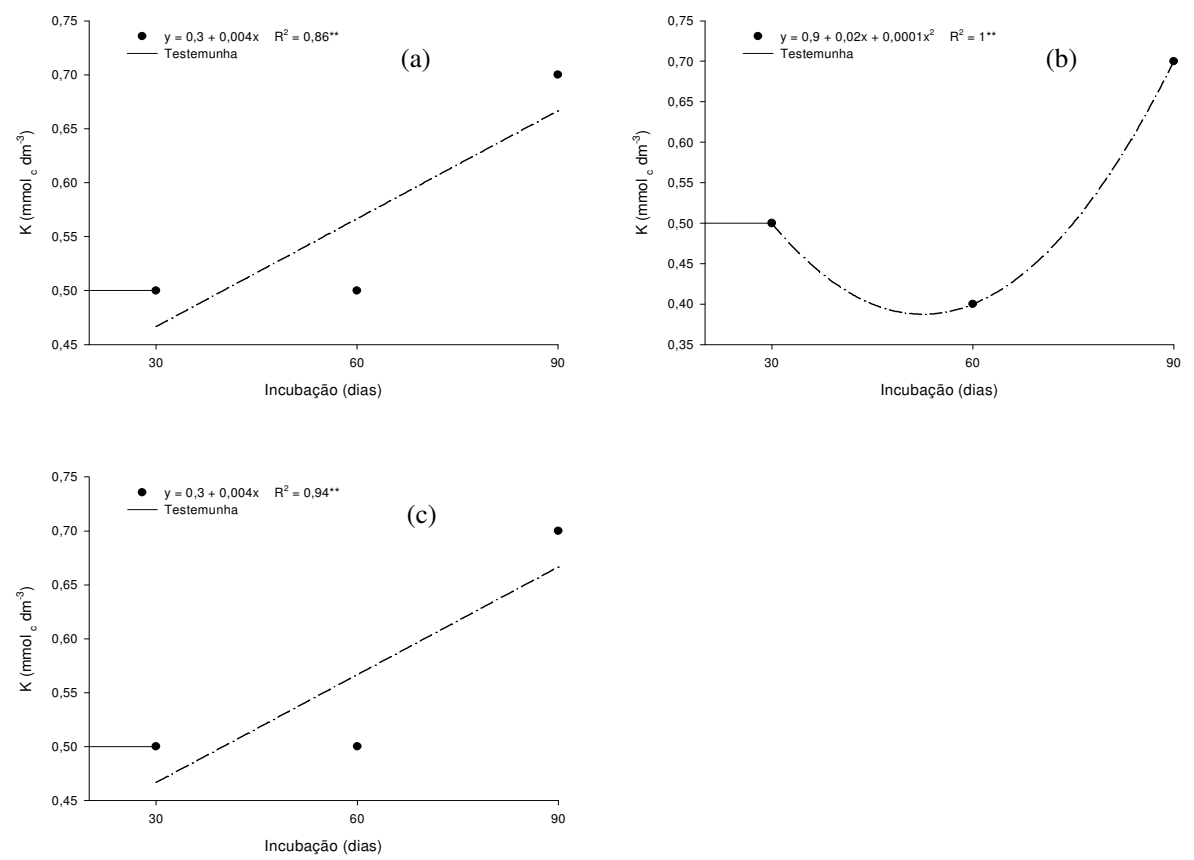

Figura 8. Valores de K no Nitossolo Vermelho eutrófico (NVe) em função dos períodos de incubação de escória (a), calcário calcítico (b) e calcário dolomítico (c). ** significativo a $1 \%$ de probabilidade.

Os corretivos não diferiram entre si na alteração dos valores de $\mathrm{pH}$ quando aplicados na granulometria $<0,30 \mathrm{~mm}$ (peneira fundo) nos três períodos de incubação (Tabelas 12, 13 e 14), e nesta granulometria todos os corretivos atingiram $\mathrm{pH}$ superior ao planejado. Aos noventa dias de incubação apenas frações granulométricas 2,0 mm (peneira 10) da escória e dos calcários não chegaram ao pH 5,5 (Tabela 14).

De modo geral, assim como ocorrido para o LVd os silicatos promoveram os maiores valores de $\mathrm{pH}$ comparado aos calcários e essa diferença foi mais significativa para a granulometria $0,84 \mathrm{~mm}$ e $2,0 \mathrm{~mm}$, correspondente as peneiras 20 e 10 .

A fração granulométrica de $0,84 \mathrm{~mm}$ (peneira 20) elevou o pH do solo no decorrer dos períodos de incubação (Figura 7), sendo os silicatos significativamente iguais entre si e superiores aos calcários (Tabelas 12, 13 e 14). A fração granulométrica 2,0 mm (peneira 10) também teve comportamento semelhante nos três períodos de avaliação, com superioridade do silicato de cálcio e magnésio, seguido do silicato de cálcio e escória a qual foi semelhante aos calcários. Nesta fração granulométrica apenas o silicato de cálcio e 
magnésio teve a dose calculada para chegar ao $\mathrm{pH} 5,5$, entretanto, aos noventa dias de incubação o silicato de cálcio proporcionou o valor de pH de 5,7.
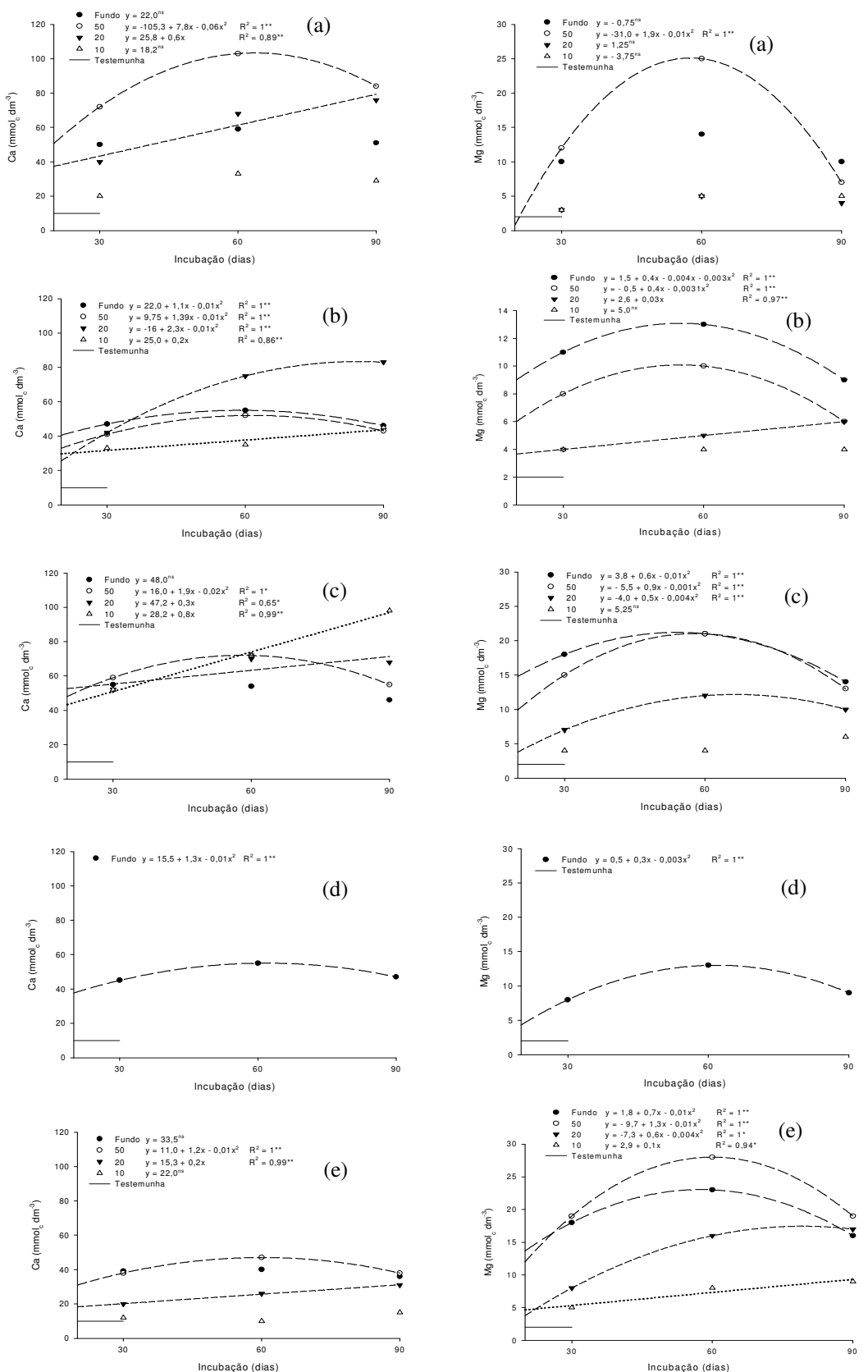

Figura 9. Desdobramento das interações granulometrias (Fundo: $\varnothing<0,30 \mathrm{~mm} ; 50: \varnothing=0,30 \mathrm{~mm} ; 20: \varnothing=0,84 \mathrm{~mm} ; 10$ : $\emptyset=2 \mathrm{~mm}$ ) x períodos de incubação para teores de Ca e Mg do Nitossolo Vermelho eutrófico (NVe) com a aplicação de escória (a), silicato de cálcio (b), silicato de cálcio e magnésio (c), wollastonita ${ }^{1}$ (d) e calcário dolomítico (e). ${ }^{*} \mathrm{e}^{* *}$ significativos a $5 \%$ e $1 \%$ de probabilidade, respectivamente. ns- não significativo. ${ }^{1}$ possui apenas a fração granulométrica $<0,30 \mathrm{~mm}$. 

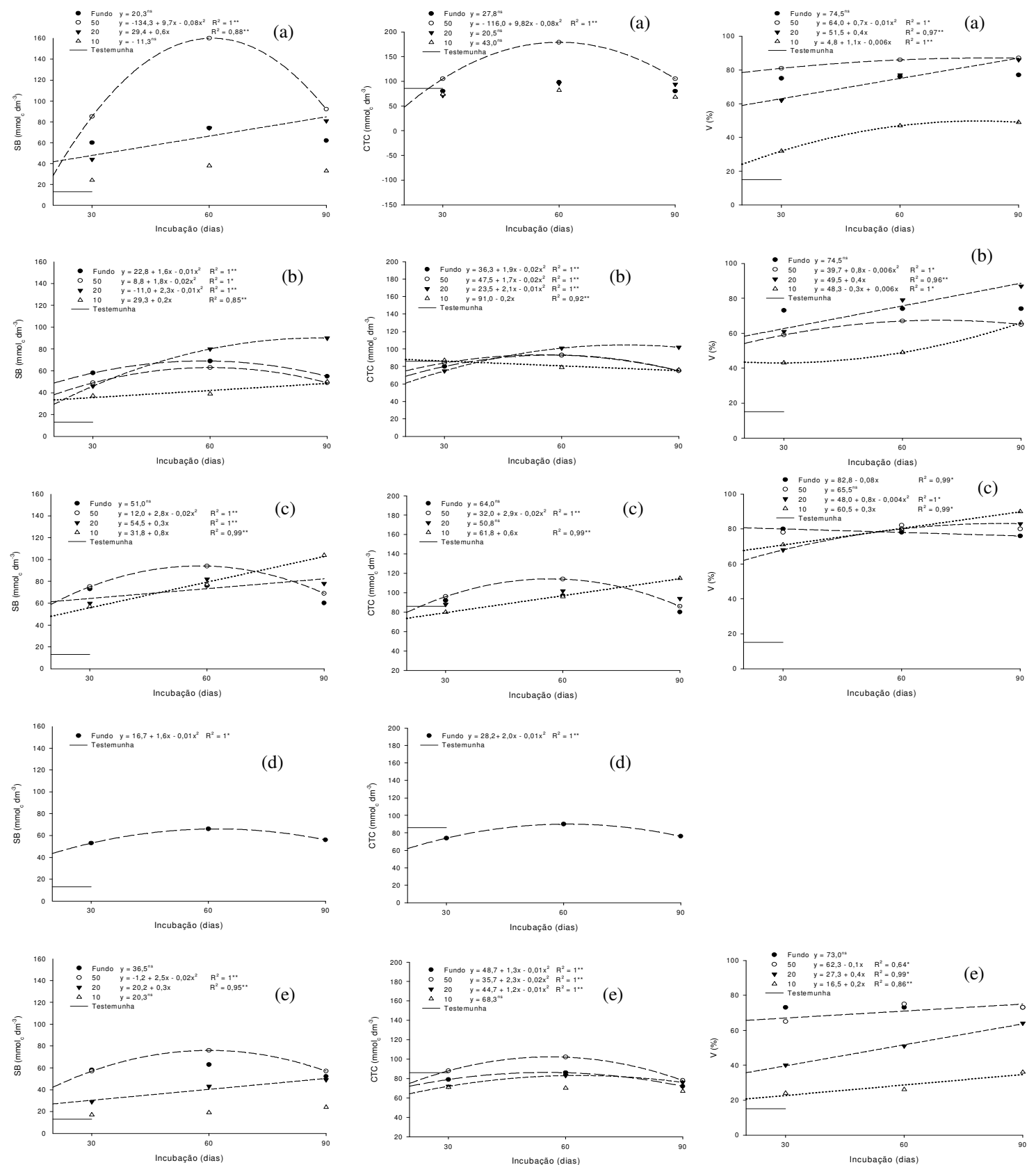

Figura 10. Desdobramento das interações granulometrias (Fundo: $\varnothing<0,30 \mathrm{~mm} ; 50: \varnothing=0,30 \mathrm{~mm} ; 20: \emptyset=0,84 \mathrm{~mm} ; 10$ : $\varnothing=2 \mathrm{~mm}$ ) x períodos de incubação para valores de SB, CTC e V\% do Nitossolo Vermelho eutrófico (NVe) com a aplicação de escória (a), silicato de cálcio (b), silicato de cálcio e magnésio (c), wollastonita ${ }^{1}$ (d) e calcário dolomítico (e). * e ** significativos a $5 \%$ e $1 \%$ de probabilidade, respectivamente. ns- não significativo. ${ }^{1}$ possui apenas a fração granulométrica $<0,30 \mathrm{~mm}$.

Entre granulometrias, observa-se que o $\mathrm{pH}$ obtido aos trinta dias de incubação com a granulometria $<0,30 \mathrm{~mm}$ (peneira fundo) da escória e do silicato de cálcio e magnésio foi significativamente igual a granulometria $0,30 \mathrm{~mm}$ (peneira 50), para os demais 
corretivos a granulometria $0,30 \mathrm{~mm}$ foi superior, tendo o valor de $\mathrm{pH}$ diminuído conforme aumentou-se os tamanhos das frações granulométricas (Tabela 12).

Com o passar do tempo de reação dos corretivos, algumas frações granulométricas tenderam a se igualar e os resultados se alteraram bastante. Verifica-se, com sessenta dias de incubação, que a granulometria $<0,30 \mathrm{~mm}$ foi significativamente igual à granulometria $0,30 \mathrm{~mm}$, apenas com exceção ao silicato de cálcio (Tabela 13). No período de noventa dias os resultados praticamente se inverteram, a granulometria $0,84 \mathrm{~mm}$ da escória e do silicato de cálcio foi superior as demais frações, já para o calcário dolomítico a granulometria $<0,30 \mathrm{~mm}, 0,30 \mathrm{~mm}$ e $0,84 \mathrm{~mm}$ não mostraram diferença significativa (Tabela 14).

Pela figura 7 nota-se um fato interessante, onde a granulometria $<0,30$ mm e a granulometria $0,30 \mathrm{~mm}$ promoveram elevação no $\mathrm{pH}$ do solo aos trinta e sessenta dias de incubação, mas aos 90 dias ocorreu redução do pH do solo. No entanto, para as frações mais grosseiras, como aquelas retidas na peneira 20 e $10(0,84 \mathrm{~mm}$ e $2,0 \mathrm{~mm}$ respectivamente), o pH elevou-se no decorrer de todos os períodos. Da mesma maneira que ocorreu para o LVd as frações mais grosseiras precisam de maior tempo de contato para reação, como as doses aplicadas para as frações mais grosseiras foram bem superiores as doses para as frações mais finas, possivelmente com maiores períodos de incubação estas frações granulométricas poderiam atingir $\mathrm{pH}$ superior as frações mais finas, que tem efeito imediato, mas não apresenta efeito residual prolongado.

A redução da acidez potencial ocorreu com a diminuição das frações granulométricas (Tabelas 12, 13 e 14), e com aumento do período de incubação (Figura 7), exceto para a wollastonita.

Assim como ocorreu para o solo LVd verifica-se que os tratamentos aumentaram bastante o teor de cálcio no solo, que inicialmente era de $7 \mathrm{mmol}_{\mathrm{c}} \mathrm{dm}^{-3}$. Para a maioria dos corretivos a granulometria de $0,30 \mathrm{~mm}$ foi superior na disponibilidade de cálcio, mas significativamente igual a granulometria $<0,30 \mathrm{~mm}$ nos períodos de trinta e sessenta dias (Tabelas 12, 13 e 14).

A maior disponibilidade de cálcio pela aplicação das maiores frações é acentuada neste solo em relação ao LVd. Com trinta e sessenta dias de incubação (Tabelas 12 e 13) a escória na granulometria $0,30 \mathrm{~mm}$ foi significativamente superior à granulometria < 
0,30 $\mathrm{mm}$. No período de noventa dias a escória manteve-se superior na disponibilidade de cálcio na granulometria $0,30 \mathrm{~mm}$, mas significativamente igual a granulometria $0,84 \mathrm{~mm}$, sendo estas superiores a granulometria $<0,30 \mathrm{~mm}$.

Aos noventa dias de incubação o silicato de cálcio na granulometria $0,84 \mathrm{~mm}$ aumentou praticamente o dobro do teor de cálcio que as demais frações granulométricas. Também teve resultado bem elevado na disponibilidade de cálcio a granulometria 2,0 $\mathrm{mm}$ do silicato de cálcio e magnésio, nota-se que para este corretivo a granulometria $<0,30 \mathrm{~mm}$ foi a que menos disponibilizou cálcio (Tabela 14).

A maior disponibilidade deste nutriente pelas frações granulométricas de maiores dimensões dos silicatos, como já mencionado para o LVd pode ter ocorrido em razão das altas doses aplicadas, no entanto, não se pode afirmar que todo esse cálcio estaria disponível para a planta. Outro fato a considerar, que está associado às altas doses aplicadas é a amostragem; com o tempo de incubação provavelmente estas partículas tiveram seu tamanho reduzido o que dificultou sua separação no peneiramento e preparo da amostra de solo, e essas pequenas partículas dos silicatos podem ter sido quantificadas.

Trabalhos com aplicação de doses iguais entre as frações granulométricas para calcários Bellingieri (1983) e para escória Prado et al. (2004) relataram superioridade das frações granulométricas mais finas em disponibilizar cálcio, sendo que frações mais grosseiras como aquelas retidas na peneira 10 não foram capazes de alterar o teor de cálcio do solo. Para a escória, mesmo incubando a fração granulométrica retida na peneira 10 por 9 meses, esta foi pouco efetiva na disponibilidade de cálcio (PRADO et al.,2004).

O teor de cálcio aumentou de trinta a sessenta dias para todos os corretivos, exceção feita ao calcário calcítico, com o qual a interação granulometrias x períodos de incubação não foi significativa, e aos noventa dias de incubação o teor de cálcio decresceu, exceto apenas para o calcário dolomítico na granulometria de $0,84 \mathrm{~mm}$ e silicato de cálcio e silicato de cálcio e magnésio na granulometria 2,0 mm (Figura 9).

Os maiores teores de magnésio, de modo geral, foram obtidos com a aplicação da granulometria $<0,30 \mathrm{~mm}$ e granulometria $0,30 \mathrm{~mm}$ do calcário dolomítico e do silicato de cálcio e magnésio (Tabelas 12, 13 e 14). Entretanto, com a incubação, a granulometria de $0,84 \mathrm{~mm}$ do calcário dolomítico se igualou com as granulometrias $<0,30$ $\mathrm{mm}$ e $0,30 \mathrm{~mm}$ aos noventa dias de incubação (Tabela 14). Assim como observado e discutido 
para o LVd a escória e o silicato de cálcio não foram eficientes na solubilização do magnésio para a forma trocável.

Em relação ao tempo de reação, a interação períodos de incubação e granulometrias só não foi significativa no teor de magnésio para o calcário calcítico, como também ocorreu para o teor de cálcio. Verifica-se pela Figura 9 que o teor de magnésio aumentou de trinta a sessenta dias, mas aos noventa dias decresceu assim como observado no LVd.

Para os teores de K a interação de granulometrias e corretivos não foi significativa, entretanto, as médias estão apresentadas nas Tabelas 12, 13 e 14. Os corretivos em todas as frações granulométricas foram pouco eficientes na disponibilização de $\mathrm{K}$ ao solo, os teores foram próximos aos encontrados na condição original do solo $\left(0,6 \mathrm{mmmol}_{\mathrm{c}} \mathrm{dm}^{-3}\right)$.

Os teores de K no solo foram influenciados pelo período de incubação, quando aplicado a escória, o silicato de cálcio e magnésio e os calcários dolomítico e calcítico (Figura 8). A aplicação destes corretivos elevou o teor de $\mathrm{K}$ no solo com o aumento no período de incubação.

A soma de bases (SB) acompanhou o resultado obtido com o cálcio e o magnésio (Tabelas 12, 13 e 14), por terem sidos os nutrientes liberados em grande quantidade. Assim como o teor destes nutrientes a SB aumentou dos trinta aos sessenta dias e decresceu aos noventa dias de incubação (Figura 10).

Diferentemente do que observado para o LVd quando se compara o valor da CTC inicial do solo $\left(80 \mathrm{mmol}_{\mathrm{c}} \mathrm{dm}^{-3}\right)$ com os valores obtidos após trinta dias da aplicação dos tratamentos, observa-se que já se tem alteração neste período, principalmente quando os corretivos foram aplicados com frações granulométricas de 0,30 mm (peneira 50).

Os corretivos tiveram diferenças significativas entre suas granulometrias nos valores da CTC e essas diferenças variaram em função da época de avaliação. De modo geral, na primeira avaliação (30 dias de incubação), os corretivos na granulometria $0,30 \mathrm{~mm}$ foram superiores às demais granulometrias, as quais não tiveram diferenças significativas entre si (Tabela 12).

Já na segunda avaliação, decorridos sessenta dias de incubação, os corretivos não tiveram diferenças em função de sua granulometria, e na terceira avaliação (90 
dias de incubação) os maiores valores de CTC foram obtidos com os corretivos na granulometria $0,30 \mathrm{~mm}$ e $0,84 \mathrm{~mm}$ (Tabelas 13 e 14).

Em relação à saturação por bases, os corretivos não diferiram na granulometria $<0,30 \mathrm{~mm}$, mas para as demais granulometrias teve-se bastante variação que dependeu do período de incubação. Para a maioria dos corretivos o valor da saturação por bases aumentou com a diminuição da granulometria, no entanto, para a escória e o silicato de cálcio e magnésio a granulometria $0,30 \mathrm{~mm}$ foi superior as demais (Tabelas 12, 13 e 14).

O valor da saturação por bases aos trinta dias de incubação aumentou com a diminuição das frações granulométricas, exceto para a escória. Já aos sessenta dias de incubação teve-se superioridade das frações de maiores dimensões para alguns corretivos, como a escória, silicato de cálcio, silicato de cálcio e magnésio e aos noventa dias este resultado se repetiu.

O resultado da comparação dos corretivos com a wollastonita aos 30, 60 e 90 dias de incubação está na Tabela 15.

A wollastonita não diferiu dos demais corretivos nos teores de cálcio, exceção feita ao período de sessenta dias em que diferiu do calcário calcítico. Para o teor de magnésio a wollastonita proporcionou pequenos acréscimos quando comparada aos demais corretivos. A aplicação da wollastonita não diferiu dos demais tratamentos nos valores de $\mathrm{pH}$ e de saturação por bases nos três períodos avaliados.

Com a incubação, de trinta a sessenta dias, a wollastonita aumentou o teor de $\mathrm{Ca}$ e $\mathrm{Mg}$ e os valores de SB, CTC e V\%, mas ocorreu decréscimo aos noventa dias (Figuras 9 e 10). 
Tabela 15 - Atributos químicos do Nitossolo Vermelho eutrófico (NVe) em função da aplicação da fração granulométrica $<0,30 \mathrm{~mm}$ (peneira fundo) dos corretivos.

\begin{tabular}{|c|c|c|c|c|c|c|c|c|}
\hline \multirow{3}{*}{ Corretivos } & $\mathrm{pH}$ & $\mathrm{H}+\mathrm{Al}$ & $\mathrm{K}$ & $\mathrm{Ca}$ & $\mathrm{Mg}$ & SB & CTC & $\mathrm{V}$ \\
\hline & \multicolumn{8}{|c|}{ 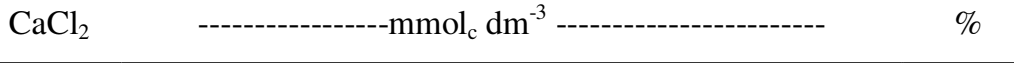 } \\
\hline & \multicolumn{8}{|c|}{30 dias } \\
\hline Escória & $6,0 \mathrm{a}$ & $21 \mathrm{ab}$ & $0,5 \mathrm{a}$ & $50 \mathrm{a}$ & $10 \mathrm{a}$ & $60 \mathrm{~b}$ & $80 \mathrm{ab}$ & $75 \mathrm{ab}$ \\
\hline Silicato Cálcio & $5,9 \mathrm{a}$ & $22 \mathrm{ab}$ & $0,6 \mathrm{a}$ & $47 \mathrm{ab}$ & $11 \mathrm{a}$ & $58 \mathrm{~b}$ & $80 \mathrm{ab}$ & $73 \mathrm{~b}$ \\
\hline Silicato de Cálcio e Magnésio & $6,2 \mathrm{a}$ & $18 \mathrm{~b}$ & $0,5 \mathrm{a}$ & $55 \mathrm{a}$ & $18 \mathrm{a}$ & $73 \mathrm{a}$ & $92 \mathrm{a}$ & $80 \mathrm{a}$ \\
\hline Wollastonita & $5,9 \mathrm{a}$ & $21 \mathrm{ab}$ & $0,5 \mathrm{a}$ & $45 \mathrm{ab}$ & $8 \mathrm{~b}$ & $53 \mathrm{~b}$ & $74 \mathrm{~b}$ & $72 b$ \\
\hline Calcário Calcítico & $6,0 \mathrm{a}$ & $20 \mathrm{ab}$ & $0,4 \mathrm{a}$ & $46 a b$ & $11 \mathrm{~b}$ & $57 \mathrm{~b}$ & $77 \mathrm{~b}$ & $74 \mathrm{ab}$ \\
\hline Calcário Dolomítico & $5,9 \mathrm{a}$ & $21 \mathrm{ab}$ & $0,5 \mathrm{a}$ & $39 \mathrm{~b}$ & $18 \mathrm{a}$ & $58 \mathrm{~b}$ & $79 \mathrm{~b}$ & $73 \mathrm{~b}$ \\
\hline \multirow[t]{2}{*}{$\mathrm{CV} \%$} & 2,5 & 6,4 & 26,7 & 11,5 & 10,0 & 10,8 & 8,0 & 3,9 \\
\hline & \multicolumn{8}{|c|}{60 dias } \\
\hline Escória & $6,4 \mathrm{a}$ & $24 \mathrm{a}$ & $0,4 \mathrm{a}$ & $59 \mathrm{a}$ & $14 \mathrm{~b}$ & $74 \mathrm{a}$ & $98 \mathrm{a}$ & $76 \mathrm{a}$ \\
\hline Silicato Cálcio & $6,3 \mathrm{a}$ & $24 \mathrm{a}$ & $0,8 \mathrm{a}$ & $55 \mathrm{a}$ & $13 \mathrm{~b}$ & $69 \mathrm{a}$ & $93 \mathrm{a}$ & $74 \mathrm{a}$ \\
\hline Silicato de Cálcio e Magnésio & $6,4 \mathrm{a}$ & $21 \mathrm{a}$ & $0,6 \mathrm{a}$ & $54 \mathrm{a}$ & $21 \mathrm{a}$ & $76 a$ & $97 \mathrm{a}$ & $78 \mathrm{a}$ \\
\hline Wollastonita & $6,3 \mathrm{a}$ & $24 \mathrm{a}$ & $0,4 \mathrm{a}$ & $55 \mathrm{a}$ & $11 \mathrm{~b}$ & $66 \mathrm{a}$ & $90 \mathrm{a}$ & $74 \mathrm{a}$ \\
\hline Calcário Calcítico & $6,5 \mathrm{a}$ & $22 \mathrm{a}$ & $0,4 \mathrm{a}$ & $54 \mathrm{a}$ & $13 \mathrm{~b}$ & $67 \mathrm{a}$ & $89 \mathrm{a}$ & $76 a$ \\
\hline Calcário Dolomítico & $6,3 \mathrm{a}$ & $23 \mathrm{a}$ & $0,6 \mathrm{a}$ & $40 \mathrm{~b}$ & $23 \mathrm{a}$ & $63 \mathrm{a}$ & $86 \mathrm{a}$ & $73 \mathrm{a}$ \\
\hline \multirow[t]{2}{*}{$\mathrm{CV} \%$} & 3,6 & 9,4 & 45,7 & 10,1 & 13,8 & 10,1 & 7,4 & 3,6 \\
\hline & \multicolumn{8}{|c|}{90 dias } \\
\hline Escória & $6,0 \mathrm{a}$ & $18 \mathrm{a}$ & $0,7 \mathrm{a}$ & $51 \mathrm{a}$ & $10 \mathrm{~b}$ & $62 \mathrm{a}$ & $80 \mathrm{a}$ & $77 \mathrm{a}$ \\
\hline Silicato Cálcio & $5,8 \mathrm{~b}$ & $19 \mathrm{a}$ & $0,5 \mathrm{a}$ & $46 \mathrm{ab}$ & $9 \mathrm{~b}$ & $55 \mathrm{a}$ & $75 \mathrm{a}$ & $74 \mathrm{a}$ \\
\hline Silicato de Cálcio e Magnésio & $6,0 \mathrm{a}$ & $20 \mathrm{a}$ & $0,6 \mathrm{a}$ & $46 \mathrm{ab}$ & $14 \mathrm{a}$ & $60 \mathrm{a}$ & $80 \mathrm{a}$ & $76 a$ \\
\hline Wollastonita & $6,0 \mathrm{a}$ & $20 \mathrm{a}$ & $0,7 \mathrm{a}$ & $47 \mathrm{ab}$ & $8 \mathrm{~b}$ & $56 \mathrm{a}$ & $76 \mathrm{a}$ & $74 \mathrm{a}$ \\
\hline Calcário Calcítico & $6,1 \mathrm{a}$ & $17 \mathrm{a}$ & $0,5 \mathrm{a}$ & $45 \mathrm{ab}$ & $9 \mathrm{~b}$ & $54 \mathrm{a}$ & $71 \mathrm{a}$ & $76 \mathrm{a}$ \\
\hline Calcário Dolomítico & $5,9 \mathrm{ab}$ & $20 \mathrm{a}$ & $0,6 \mathrm{a}$ & $36 \mathrm{~b}$ & $16 \mathrm{a}$ & $52 \mathrm{a}$ & $72 \mathrm{a}$ & $73 \mathrm{a}$ \\
\hline $\mathrm{CV} \%$ & 2,0 & 8,4 & 39,6 & 14,2 & 10,8 & 11,5 & 8,3 & 4,0 \\
\hline
\end{tabular}

\subsubsection{Neossolo Quartzarênico (NQ)}

As interações corretivos x granulometrias aos 30, 60 e 90 dias de incubação foram significativos para o $\mathrm{pH} \mathrm{CaCl} \mathrm{Ca}_{2} ; \mathrm{H}+\mathrm{Al} ; \mathrm{Ca} ; \mathrm{Mg}$; $\mathrm{SB}$; CTC e V\%, cujos desdobramentos estão apresentados nas Tabelas 16, 17 e 18.

Neste solo também avaliou-se o efeito da granulometria no decorrer dos períodos de incubação. A interação granulometrias $\mathrm{x}$ períodos de incubação foi significativa nos valores de $\mathrm{pH}$ e $\mathrm{H}+\mathrm{Al}$ para todos os corretivos (Figura 11), no teor de cálcio com aplicação do silicato de cálcio e magnésio e da wollastonita (Figura 13), no teor de magnésio com aplicação do silicato de cálcio e magnésio, wollastonita, silicato de cálcio e calcário dolomítico (Figura 13). A interação granulometrias e períodos de incubação foi significativa nos valores de SB apenas com a aplicação do silicato de cálcio e magnésio e 
calcário dolomítico, nos valores de CTC quando aplicado escória e o calcário dolomítico e nos valores de V\% com a aplicação do silicato de cálcio e silicato de cálcio e magnésio (Figura $14)$.

Quando a interação granulometrias x períodos de incubação não foi significativa considerou-se o efeito do período de incubação, o qual foi significativo para o teor de cálcio, quando aplicado a escória e o silicato de cálcio (Figura 12), para o teor de magnésio quando aplicado escória e o calcário calcítico (Figura 12), e também foi significativo no valor de soma de bases com a aplicação da escória e silicato de cálcio e magnésio e no valor da CTC com aplicação do silicato de cálcio, silicato de cálcio e magnésio e calcário calcítico (Figura 15).

Aos trinta dias de incubação, apenas a escória na granulometria 2,0 mm não chegou ao $\mathrm{pH} 5,5$, embora estivesse próxima no período de sessenta dias, reduziu aos noventa dias de incubação. Mesmo não sendo possível calcular a dose a ser aplicada de escória e calcário dolomítico na granulometria $2,0 \mathrm{~mm}$ (peneira 10), a aplicação para estes corretivos com a dose obtida pela equação da granulometria $0,84 \mathrm{~mm}$ (peneira 20) atingiu o pH 5,5 no período de sessenta dias; entretanto aos noventa dias o $\mathrm{pH}$ reduziu. Para as demais granulometrias o valor de $\mathrm{pH}$ foi superior ao planejado e de modo geral, verificou-se superioridade dos silicatos na elevação do $\mathrm{pH}$.

Analisando o efeito da granulometria percebe-se que neste solo não ocorreu tanta diferença de tempo de reação entre as frações granulométricas. Algumas granulometrias já na primeira avaliação foram significativamente iguais na alteração do $\mathrm{pH}$ como as granulometrias: $<0,30 \mathrm{~mm}, 0,30 \mathrm{~mm}$ e $0,84 \mathrm{~mm}$ da escória, do silicato de cálcio e magnésio e do calcário dolomítico, e para o silicato de cálcio e para o calcário calcítico a granulometria $<0,30 \mathrm{~mm}$ não diferiu da granulometria $0,30 \mathrm{~mm}$ e este fato se repetiu aos sessenta dias. Aos noventa dias, para alguns corretivos as granulometrias 0,30 mm e 0,84 mm passaram a ser superior à granulometria $<0,30 \mathrm{~mm}$ (Tabelas 16, 17 e 18). 
Tabela 16-Desdobramento das interações corretivos x granulometrias para atributos químicos do Neossolo Quartzarênico (NQ) após 30 dias de incubação.

\begin{tabular}{|c|c|c|c|c|}
\hline \multirow{2}{*}{ Corretivos } & \multicolumn{4}{|c|}{ Granulometrias (mm) } \\
\hline & $<0,30$ & 0,30 & 0,84 & 2,00 \\
\hline & \multicolumn{4}{|c|}{$\mathrm{pH}\left(\mathrm{CaCl}_{2}\right)$} \\
\hline Escória & $6,3 \mathrm{aA}$ & $6,1 \mathrm{bcA}$ & $5,9 \mathrm{aA}$ & $4,9 \mathrm{cB}$ \\
\hline Silicato de cálcio & 6,3 aA & 6,6 aA & $5,5 \mathrm{bB}$ & $5,4 \mathrm{abB}$ \\
\hline Silicato de cálcio e magnésio & $6,2 \mathrm{abA}$ & $6,2 \mathrm{bA}$ & $6,1 \mathrm{aA}$ & $5,5 \mathrm{aB}$ \\
\hline Calcário calcítico & $5,8 \mathrm{bA}$ & $5,8 \mathrm{cdA}$ & $5,4 \mathrm{bB}$ & $5,0 \mathrm{bcC}$ \\
\hline Calcário dolomítico & $5,9 \mathrm{bA}$ & $5,6 \mathrm{dAB}$ & $6,0 \mathrm{aA}$ & $5,3 \mathrm{abcB}$ \\
\hline \multirow[t]{2}{*}{$\mathrm{CV} \%$} & \multicolumn{4}{|c|}{3,3} \\
\hline & \multicolumn{4}{|c|}{$\mathrm{H}+\mathrm{Al}\left(\mathrm{mmol}_{\mathrm{c}} \mathrm{dm}^{-3}\right)$} \\
\hline Escória & $11 \mathrm{bC}$ & $12 \mathrm{bBC}$ & $13 \mathrm{bcB}$ & $19 \mathrm{aA}$ \\
\hline Silicato de cálcio & $12 \mathrm{abC}$ & $10 \mathrm{cB}$ & $15 \mathrm{abA}$ & $16 \mathrm{cdA}$ \\
\hline Silicato de cálcio e magnésio & $12 \mathrm{abB}$ & $12 \mathrm{bB}$ & $12 \mathrm{cB}$ & $14 \mathrm{dA}$ \\
\hline Calcário calcítico & $13 \mathrm{abC}$ & $15 \mathrm{aBC}$ & $16 \mathrm{aB}$ & $18 \mathrm{abA}$ \\
\hline Calcário dolomítico & $13 \mathrm{aB}$ & $14 \mathrm{aB}$ & $13 \mathrm{cB}$ & $17 \mathrm{bcA}$ \\
\hline \multirow[t]{2}{*}{$\mathrm{CV} \%$} & \multicolumn{4}{|c|}{7,0} \\
\hline & \multicolumn{4}{|c|}{$\mathrm{Ca}\left(\mathrm{mmol}_{\mathrm{c}} \mathrm{dm}^{-3}\right)$} \\
\hline Escória & $32 \mathrm{abA}$ & $41 \mathrm{abA}$ & $34 \mathrm{aA}$ & $20 \mathrm{aB}$ \\
\hline Silicato de cálcio & $39 \mathrm{aA}$ & $45 \mathrm{aA}$ & $28 \mathrm{abB}$ & $25 \mathrm{aB}$ \\
\hline Silicato de cálcio e magnésio & $33 \mathrm{abA}$ & 38 abcA & $32 \mathrm{abA}$ & $21 \mathrm{aB}$ \\
\hline Calcário calcítico & $23 \mathrm{bAB}$ & 32 bcA & $24 \mathrm{bAB}$ & $19 \mathrm{aB}$ \\
\hline Calcário dolomítico & $25 \mathrm{bA}$ & $27 \mathrm{cA}$ & $25 \mathrm{abA}$ & $21 \mathrm{aA}$ \\
\hline \multirow[t]{2}{*}{$\mathrm{CV} \%$} & \multicolumn{4}{|c|}{18,4} \\
\hline & \multicolumn{4}{|c|}{$\mathrm{Mg}\left(\mathrm{mmol}_{\mathrm{c}} \mathrm{dm}^{-3}\right)$} \\
\hline Escória & $7 \mathrm{abAB}$ & $9 \mathrm{aA}$ & $6 \mathrm{aB}$ & $5 \mathrm{bB}$ \\
\hline Silicato de cálcio & $10 \mathrm{aA}$ & $9 \mathrm{aAB}$ & $6 \mathrm{aBC}$ & $5 \mathrm{bC}$ \\
\hline Silicato de cálcio e magnésio & $10 \mathrm{aA}$ & $10 \mathrm{aA}$ & $7 \mathrm{aB}$ & $4 \mathrm{bB}$ \\
\hline Calcário calcítico & $6 \mathrm{bAB}$ & $8 \mathrm{aA}$ & $7 \mathrm{aAB}$ & $5 \mathrm{bB}$ \\
\hline Calcário dolomítico & $9 \mathrm{aA}$ & $9 \mathrm{aA}$ & $8 \mathrm{aA}$ & $9 \mathrm{aA}$ \\
\hline \multirow[t]{2}{*}{$\mathrm{CV} \%$} & \multicolumn{4}{|c|}{20,0} \\
\hline & \multicolumn{4}{|c|}{$\mathrm{K}\left(\mathrm{mmol}_{\mathrm{c}} \mathrm{dm}^{-3}\right)$} \\
\hline Escória & $0,8 \mathrm{aA}$ & $0,9 \mathrm{aA}$ & $0,8 \mathrm{aA}$ & $0,8 \mathrm{aA}$ \\
\hline Silicato de cálcio & $0,9 \mathrm{aA}$ & $0,9 \mathrm{aA}$ & $0,9 \mathrm{aA}$ & $0,9 \mathrm{aA}$ \\
\hline Silicato de cálcio e magnésio & $1,0 \mathrm{aA}$ & $0,9 \mathrm{aA}$ & $0,8 \mathrm{aA}$ & $0,8 \mathrm{aA}$ \\
\hline Calcário calcítico & $0,8 \mathrm{aA}$ & $0,8 \mathrm{aA}$ & $0,8 \mathrm{aA}$ & $0,8 \mathrm{aA}$ \\
\hline Calcário dolomítico & $0,8 \mathrm{aAB}$ & $1,0 \mathrm{aA}$ & $0,8 \mathrm{aAB}$ & $0,7 \mathrm{aB}$ \\
\hline \multirow[t]{2}{*}{$\mathrm{CV} \%$} & \multicolumn{4}{|c|}{16,0} \\
\hline & \multicolumn{4}{|c|}{$\mathrm{SB}\left(\mathrm{mmol}_{\mathrm{c}} \mathrm{dm}^{-3}\right)$} \\
\hline Escória & 39 abcA & $51 \mathrm{aA}$ & $41 \mathrm{aA}$ & $26 \mathrm{aB}$ \\
\hline Silicato de cálcio & $49 \mathrm{aA}$ & $54 \mathrm{aA}$ & $35 \mathrm{aB}$ & $32 \mathrm{aB}$ \\
\hline Silicato de cálcio e magnésio & $44 \mathrm{abA}$ & $49 \mathrm{abA}$ & 39 aA & $26 \mathrm{aB}$ \\
\hline Calcário calcítico & $30 \mathrm{cAB}$ & $41 \mathrm{abA}$ & $34 \mathrm{aAB}$ & $25 \mathrm{aB}$ \\
\hline Calcário dolomítico & $35 \mathrm{bcA}$ & $37 \mathrm{bA}$ & $31 \mathrm{aA}$ & $30 \mathrm{aA}$ \\
\hline $\mathrm{CV} \%$ & & & & \\
\hline & & & & \\
\hline Escória & $50 \mathrm{abcB}$ & $62 \mathrm{abA}$ & $54 \mathrm{aAB}$ & $44 \mathrm{aB}$ \\
\hline Silicato de cálcio & $61 \mathrm{aAB}$ & $64 \mathrm{aA}$ & $50 \mathrm{aBC}$ & $48 \mathrm{aC}$ \\
\hline Silicato de cálcio e magnésio & $55 \mathrm{abA}$ & $60 \mathrm{abA}$ & $51 \mathrm{aAB}$ & $40 \mathrm{aB}$ \\
\hline Calcário calcítico & $42 \mathrm{cB}$ & $56 \mathrm{abA}$ & $47 \mathrm{aAB}$ & $43 \mathrm{aB}$ \\
\hline Calcário dolomítico & $47 \mathrm{bcA}$ & $51 \mathrm{bA}$ & $46 \mathrm{aA}$ & $47 \mathrm{aA}$ \\
\hline $\mathrm{CV} \%$ & & & & \\
\hline & & & & \\
\hline Escória & 78 abcA & $81 \mathrm{abA}$ & $76 \mathrm{aA}$ & $57 \mathrm{bB}$ \\
\hline Silicato de cálcio & $81 \mathrm{aA}$ & $85 \mathrm{aA}$ & $70 \mathrm{abB}$ & $66 \mathrm{aB}$ \\
\hline Silicato de cálcio e magnésio & $79 \mathrm{abA}$ & 80 abcA & $76 \mathrm{aA}$ & $64 \mathrm{abB}$ \\
\hline Calcário calcítico & $70 \mathrm{cAB}$ & 74 bcA & $67 \mathrm{bB}$ & $57 \mathrm{bC}$ \\
\hline Calcário dolomítico & $72 \mathrm{bcA}$ & $73 \mathrm{cA}$ & $73 \mathrm{abA}$ & $64 \mathrm{abB}$ \\
\hline
\end{tabular}

Letras maiúsculas correspondem ás comparações entre as granulometrias para o mesmo corretivo de acidez do solo pelo teste de Tukey com nível de significância $(\alpha)$ 0,05. Letras minúsculas correspondem ás comparações entre os corretivos de acidez do solo dentro da mesma granulometria pelo teste de Tukey com nível de significância $(\alpha) 0,05$. 
Tabela 17-Desdobramento das interações corretivos x granulometrias para atributos químicos do Neossolo Quartzarênico (NQ) após 60 dias de incubação.

\begin{tabular}{|c|c|c|c|c|}
\hline \multirow{2}{*}{ Corretivos } & \multicolumn{4}{|c|}{ Granulometrias } \\
\hline & $<0,30$ & 0,30 & 0,84 & 2,00 \\
\hline & \multicolumn{4}{|c|}{$\mathrm{pH}\left(\mathrm{CaCl}_{2}\right)$} \\
\hline Escória & $6,8 \mathrm{aA}$ & $6,7 \mathrm{aA}$ & $6,6 \mathrm{abA}$ & $5,4 \mathrm{cB}$ \\
\hline Silicato de cálcio e magnésio & $6,7 \mathrm{abAB}$ & $6,7 \mathrm{aAB}$ & $6,8 \mathrm{aA}$ & $6,4 \mathrm{aB}$ \\
\hline Calcário calcítico & $6,5 \mathrm{abA}$ & $6,3 \mathrm{bAB}$ & $6,0 \mathrm{cB}$ & $5,5 \mathrm{cC}$ \\
\hline Calcário dolomítico & $6,3 \mathrm{bA}$ & $6,3 \mathrm{bA}$ & $6,5 \mathrm{abA}$ & $5,7 \mathrm{bcB}$ \\
\hline $\mathrm{CV} \%$ & \multicolumn{4}{|c|}{$\mathrm{H}+\mathrm{Al}\left(\mathrm{mmol}_{\mathrm{c}} \mathrm{dm}^{-3}\right)$} \\
\hline Escória & $12 \mathrm{aB}$ & $11 \mathrm{bcB}$ & $11 \mathrm{bB}$ & $19 \mathrm{aA}$ \\
\hline Silicato de cálcio & $12 \mathrm{aBC}$ & $10 \mathrm{cC}$ & $13 \mathrm{abAB}$ & $15 \mathrm{bA}$ \\
\hline Silicato de cálcio e magnésio & $12 \mathrm{aA}$ & 12 abcA & $11 \mathrm{bA}$ & $13 \mathrm{bA}$ \\
\hline Calcário calcítico & $12 \mathrm{aB}$ & $13 \mathrm{abB}$ & $15 \mathrm{aB}$ & $17 \mathrm{aA}$ \\
\hline Calcário dolomítico & $14 \mathrm{aB}$ & $14 \mathrm{aAB}$ & $12 \mathrm{abB}$ & $15 \mathrm{bA}$ \\
\hline Silicato de cálcio & $21 \mathrm{aB}$ & $39 \mathrm{abA}$ & $22 \mathrm{aB}$ & $21 \mathrm{aB}$ \\
\hline Silicato de cálcio e magnésio & $25 \mathrm{aA}$ & $27 \mathrm{bcA}$ & $29 \mathrm{aA}$ & $24 \mathrm{aA}$ \\
\hline Calcário calcítico & $23 \mathrm{aAB}$ & $21 \mathrm{aAB}$ & $36 \mathrm{aA}$ & $12 \mathrm{aB}$ \\
\hline Calcário dolomítico & $18 \mathrm{aA}$ & $25 \mathrm{bcA}$ & $23 \mathrm{aA}$ & $13 \mathrm{aA}$ \\
\hline \multirow[t]{2}{*}{$\mathrm{CV} \%$} & \multicolumn{4}{|c|}{32,5} \\
\hline & \multicolumn{4}{|c|}{$\mathrm{Mg}\left(\mathrm{mmol}_{\mathrm{c}} \mathrm{dm}^{-3}\right)$} \\
\hline Escória & $8 \mathrm{aA}$ & $10 \mathrm{aA}$ & $6 \mathrm{bA}$ & $6 \mathrm{aA}$ \\
\hline Silicato de cálcio & $8 \mathrm{aA}$ & $8 \mathrm{aA}$ & $6 \mathrm{bA}$ & $5 \mathrm{aA}$ \\
\hline Silicato de cálcio e magnésio & $10 \mathrm{aA}$ & $10 \mathrm{aA}$ & $8 \mathrm{bAB}$ & $5 \mathrm{aB}$ \\
\hline Calcário calcítico & $6 \mathrm{aB}$ & $9 \mathrm{aB}$ & $14 \mathrm{aA}$ & $5 \mathrm{aB}$ \\
\hline Calcário dolomítico & $10 \mathrm{aA}$ & $10 \mathrm{aA}$ & $10 \mathrm{abA}$ & $10 \mathrm{aA}$ \\
\hline $\mathrm{CV} \%$ & \multicolumn{4}{|c|}{29,5} \\
\hline $\mathrm{CV} \%$ & \multicolumn{4}{|c|}{$\mathrm{SB}\left(\mathrm{mmol}_{\mathrm{c}} \mathrm{dm}^{-3}\right)$} \\
\hline Escória & $36 \mathrm{aB}$ & $56 \mathrm{aA}$ & $32 \mathrm{abB}$ & $20 \mathrm{aB}$ \\
\hline Silicato de cálcio & $30 \mathrm{aAB}$ & $48 \mathrm{abA}$ & $28 \mathrm{bB}$ & $28 \mathrm{aB}$ \\
\hline Silicato de cálcio e magnésio & $36 \mathrm{aA}$ & $38 \mathrm{abA}$ & $38 \mathrm{abA}$ & $30 \mathrm{aA}$ \\
\hline Calcário calcítico & $30 \mathrm{aB}$ & $30 \mathrm{bB}$ & $51 \mathrm{aA}$ & $18 \mathrm{aB}$ \\
\hline Calcário dolomítico & $29 \mathrm{aA}$ & $36 \mathrm{bA}$ & $34 \mathrm{abA}$ & $23 \mathrm{aA}$ \\
\hline $\mathrm{CV} \%$ & & & & \\
\hline & & & $\left.\mathrm{m}^{-3}\right)$ & \\
\hline Escória & $47 \mathrm{aB}$ & $67 \mathrm{aA}$ & $44 \mathrm{bB}$ & $39 \mathrm{aB}$ \\
\hline Silicato de cálcio & $42 \mathrm{aA}$ & $57 \mathrm{abA}$ & $41 \mathrm{bA}$ & $42 \mathrm{aA}$ \\
\hline Silicato de cálcio e magnésio & $48 \mathrm{aA}$ & $49 \mathrm{abA}$ & $49 \mathrm{abA}$ & $43 \mathrm{aA}$ \\
\hline Calcário calcítico & $43 \mathrm{aB}$ & $43 \mathrm{bB}$ & $43 \mathrm{bB}$ & $36 \mathrm{aB}$ \\
\hline Calcário dolomítico & $41 \mathrm{aA}$ & $50 \mathrm{abA}$ & $50 \mathrm{abA}$ & $39 \mathrm{aA}$ \\
\hline $\mathrm{CV} \%$ & & & & \\
\hline & & & & \\
\hline Escória & $75 \mathrm{aAB}$ & $83 \mathrm{aA}$ & $74 \mathrm{abB}$ & $52 \mathrm{cdC}$ \\
\hline Silicato de cálcio & $71 \mathrm{aB}$ & $82 \mathrm{aA}$ & $68 \mathrm{bB}$ & $66 \mathrm{abB}$ \\
\hline Silicato de cálcio e magnésio & $75 \mathrm{aA}$ & $77 \mathrm{abA}$ & $78 \mathrm{aA}$ & $71 \mathrm{aA}$ \\
\hline Calcário calcítico & $68 \mathrm{aA}$ & $70 \mathrm{bA}$ & $73 \mathrm{abA}$ & $50 \mathrm{~dB}$ \\
\hline Calcário dolomítico & $70 \mathrm{aA}$ & $72 \mathrm{bA}$ & $73 \mathrm{abA}$ & $61 \mathrm{bcB}$ \\
\hline $\mathrm{CV} \%$ & & & & \\
\hline
\end{tabular}

Letras maiúsculas correspondem ás comparações entre as granulometrias para o mesmo corretivo de acidez do solo pelo teste de Tukey com nível de significância $(\alpha)$ 0,05. Letras minúsculas correspondem ás comparações entre os corretivos de acidez do solo dentro da mesma granulometria pelo teste de Tukey com nível de significância $(\alpha) 0,05$. 
Tabela 18-Desdobramento das interações corretivos $\mathrm{x}$ granulometrias para atributos químicos do Neossolo Quartzarênico (NQ) após 90 dias de incubação

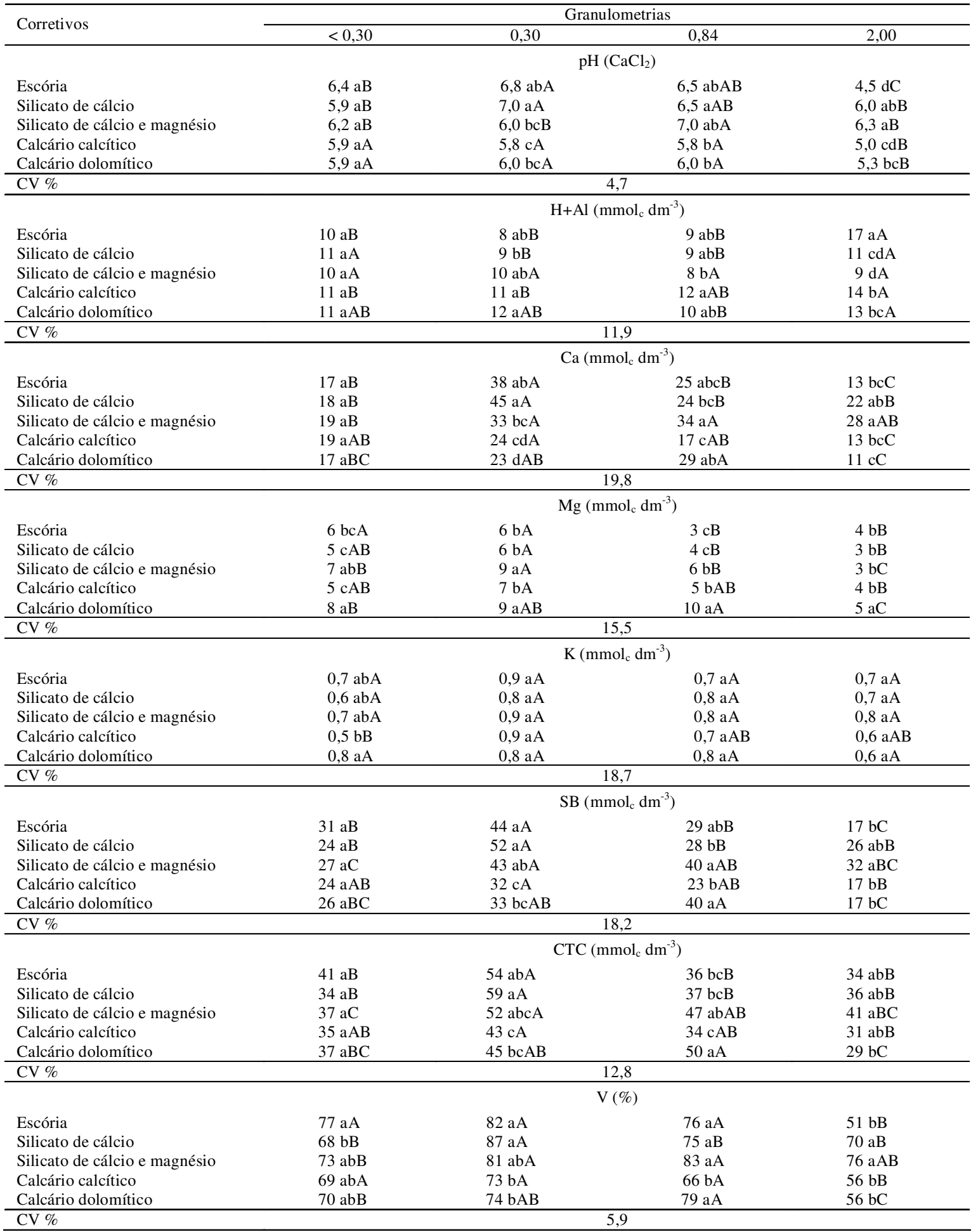

Letras maiúsculas correspondem ás comparações entre as peneiras para o mesmo corretivo de acidez do solo pelo teste de Tukey com nível de significância $(\alpha)$ 0,05. Letras minúsculas correspondem ás comparações entre os corretivos de acidez do solo dentro da mesma peneira pelo teste de Tukey com nível de significância $(\alpha) 0,05$. 

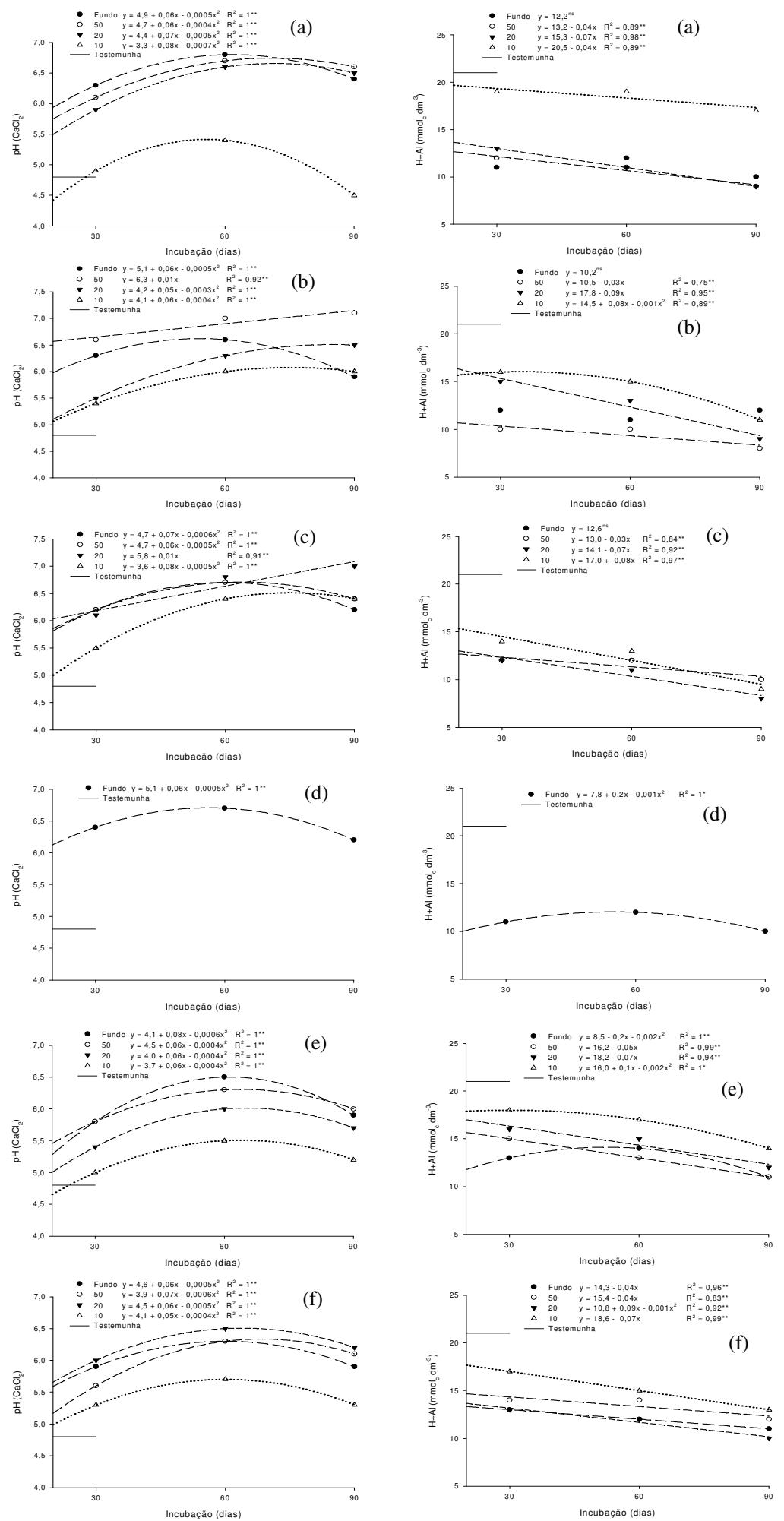

Figura 11. Desdobramento das interações granulometrias (Fundo: $\varnothing<0,30 \mathrm{~mm} ; 50: \varnothing=0,30 \mathrm{~mm} ; 20: \varnothing=0,84 \mathrm{~mm} ; 10: \varnothing=2 \mathrm{~mm}$ ) $\mathrm{x}$ períodos de incubação para valores de $\mathrm{pH}$ e $\mathrm{H}+\mathrm{Al}$ do Neossolo Quartzarênico (NQ) com a aplicação de escória (a), silicato de cálcio (b), silicato de cálcio e magnésio (c), wollastonita ${ }^{1}$ (d), calcário calcítico (e) e calcário dolomítico (f). * e ** significativos a 5\% e $1 \%$ de probabilidade, respectivamente. ns- não significativo. ${ }^{1}$ possui apenas a fração granulométrica $<0,30 \mathrm{~mm}$. 

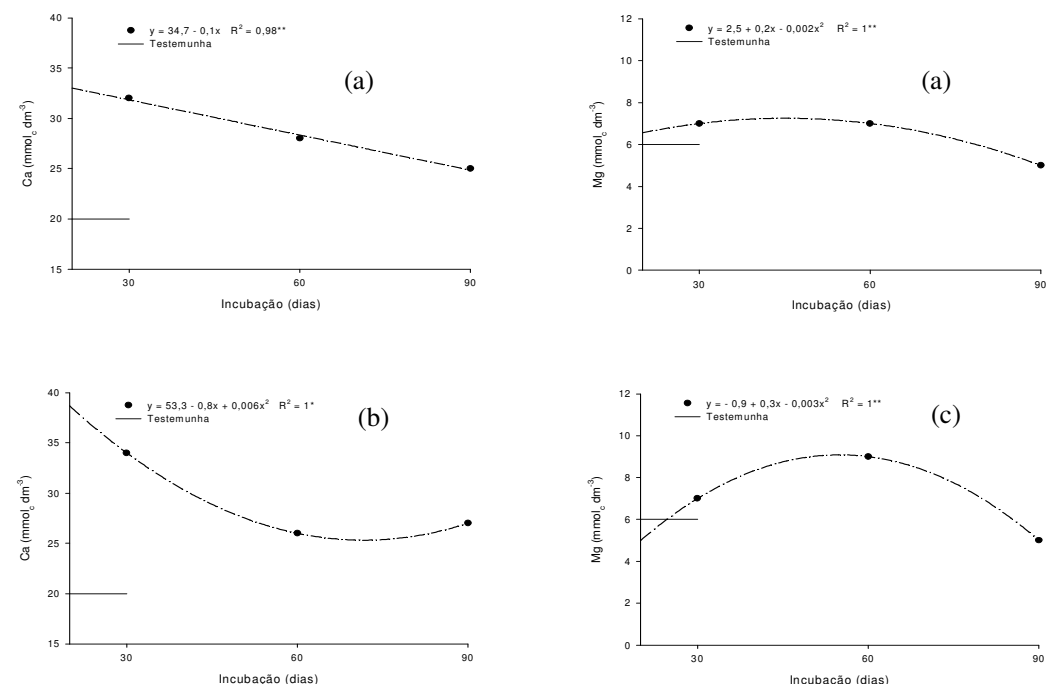

Figura 12. Teores de Ca e Mg do Neossolo Quartzarênico (NQ) em função dos períodos de incubação de escória (a), silicato de cálcio (b) e calcário calcítico (c). * e ** significativos a $5 \%$ e $1 \%$ de probabilidade, respectivamente.
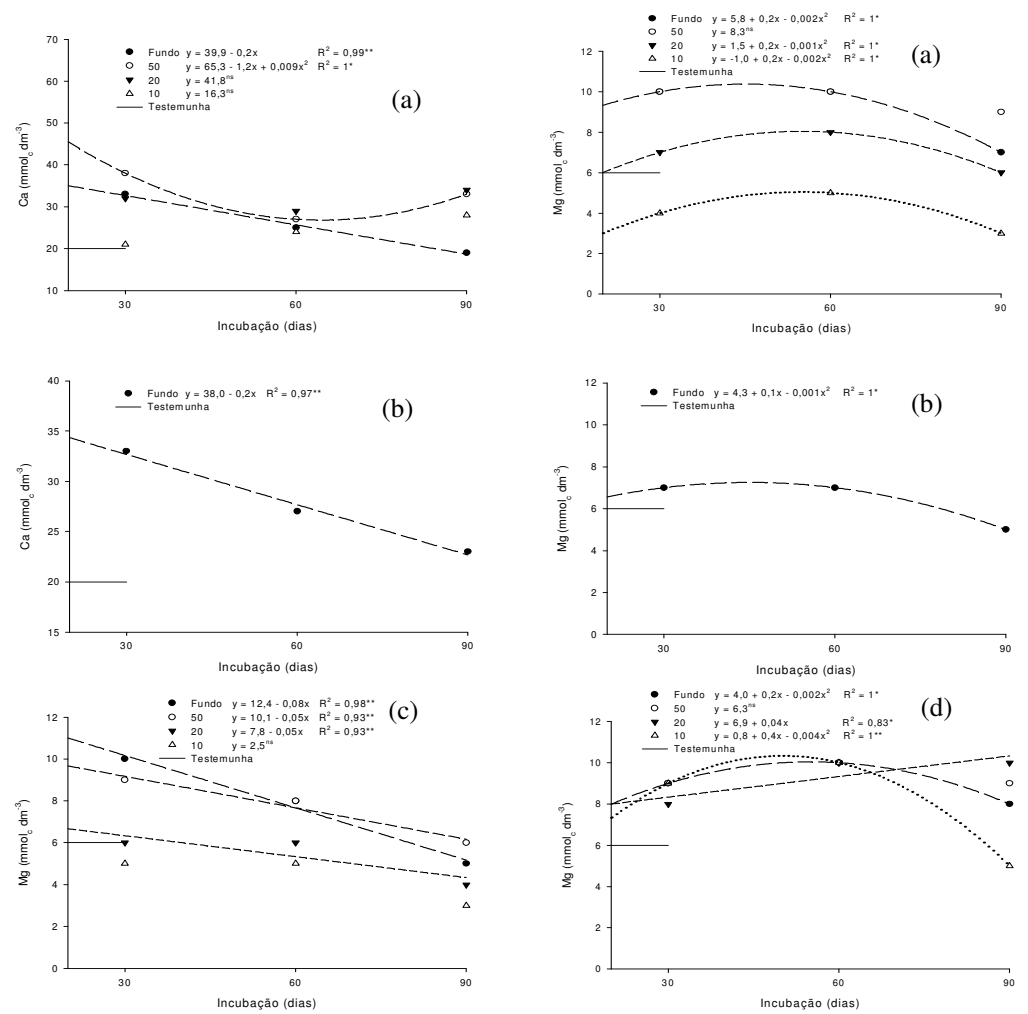

Figura 13. Desdobramento das interações granulometrias (Fundo: $\varnothing<0,30 \mathrm{~mm} ; 50: \varnothing=0,30 \mathrm{~mm} ; 20: \varnothing=0,84 \mathrm{~mm} ; 10: \varnothing=2 \mathrm{~mm}$ ) $\mathrm{x}$ períodos de incubação para teores de Ca e Mg do Neossolo Quartzarênico (NQ) com a aplicação de silicato de cálcio e magnésio (a), wollastonita ${ }^{1}$ (b), silicato de cálcio (c) e calcário dolomítico (d). $*$ e $* *$ significativos a $5 \%$ e $1 \%$ de probabilidade, respectivamente. ns- não significativo. ${ }^{1}$ possui apenas a fração granulométrica $<0,30 \mathrm{~mm}$. 

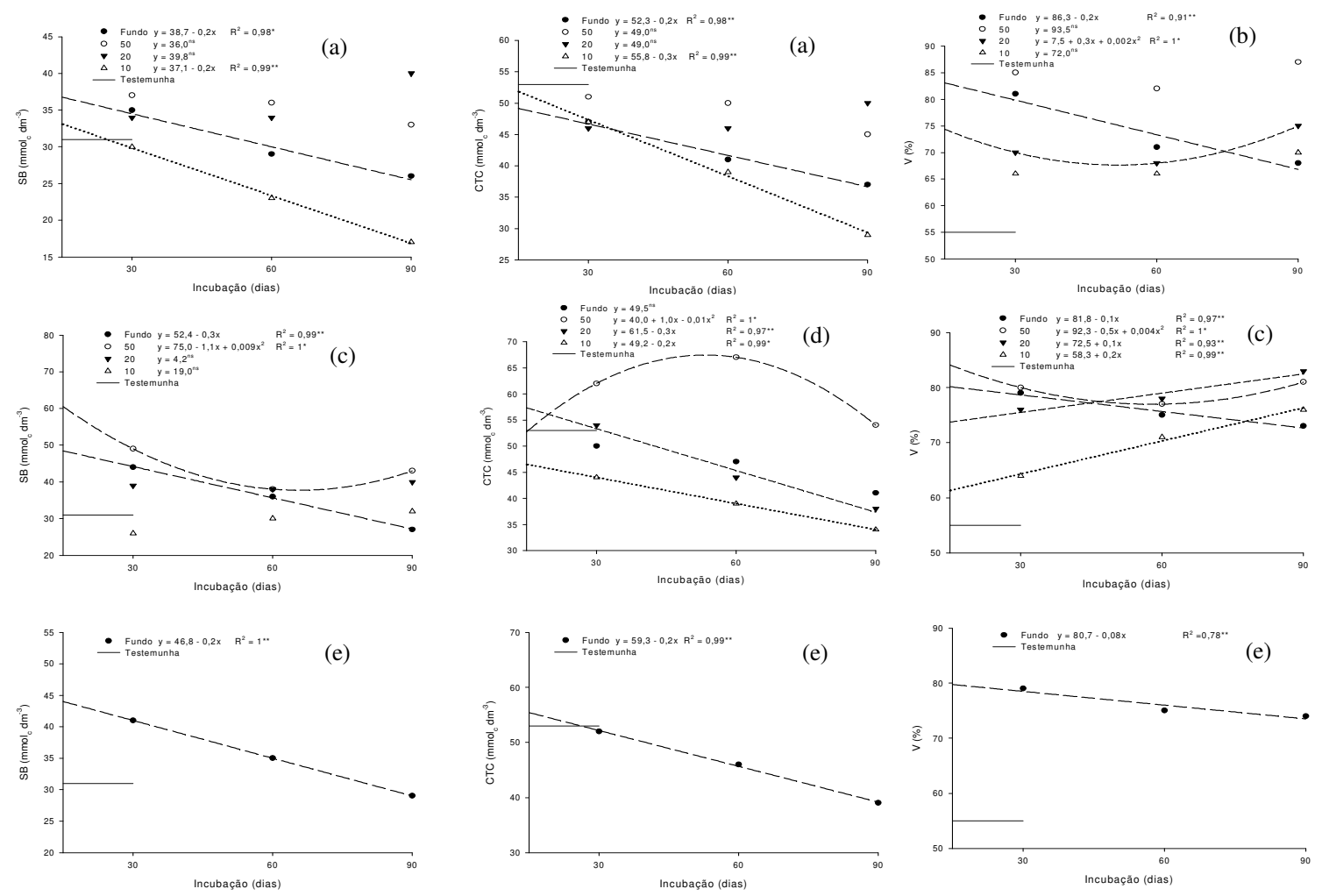

Figura 14. Desdobramento das interações granulometrias (Fundo: $\emptyset<0,30 \mathrm{~mm} ; 50: \varnothing=0,30 \mathrm{~mm} ; 20: \varnothing=0,84 \mathrm{~mm} ; 10: \varnothing=2 \mathrm{~mm}$ ) x períodos de incubação para valores de SB, CTC e V\% do Neossolo Quartzarênico (NQ) com a aplicação de calcário dolomítico (a), silicato de cálcio (b), silicato de cálcio e magnésio (c) escória (d), e wollastonita ${ }^{1}$ (e). ${ }^{*}$ e ** significativos a $5 \%$ e $1 \%$ de probabilidade, respectivamente. ns- não significativo. ${ }^{1}$ possui apenas a fração granulométrica $<0,30 \mathrm{~mm}$.

A velocidade na neutralização da acidez do solo pelos corretivos está representada pela Figura 11. Verifica-se que ocorreu elevação no valor de pH dos trinta aos sessenta dias de incubação, mas para alguns corretivos o pH decresceu com noventa dias de incubação, assim a acidez potencial reduziu dos trinta aos sessenta dias e elevou-se aos noventa dias.

Os teores de cálcio foram bem elevados assim como verificado para o LVd e NVe. Com trinta dias de incubação para todos os corretivos a peneira fundo e peneira 50 foram iguais, no entanto pode-se notar que os teores de cálcio foram maiores com a aplicação da peneira 50, e nos demais períodos esta peneira também se destacou, sendo superior as demais (Tabelas 16, 17 e 18). 
Entre corretivos teve-se bastante semelhança nos teores de cálcio no solo, mas é possível notar que os maiores teores foram obtidos com aplicação dos silicatos embora em alguns casos foram significativamente iguais aos calcários. O teor de cálcio diminuiu com a incubação, (Figuras 12 e 13), tendo apenas algumas exceções.

Verifica-se pelo valor inicial de magnésio do solo $\left(6 \mathrm{mmol}_{\mathrm{c}} \mathrm{dm}^{-3}\right)$ (Tabela 1), que os tratamentos tiveram pouca influência nos teores deste nutriente. Os maiores teores de magnésio foram obtidos com a aplicação do calcário dolomítico e do silicato de cálcio e magnésio, como também verificado para os demais solos estudados. No entanto, para o NQ o calcário dolomítico e o silicato de cálcio e magnésio não diferiram da escória e do silicato de cálcio na granulometria $<0,30 \mathrm{~mm}$ e $0,30 \mathrm{~mm}$ aos trinta e sessenta dias de incubação. Para o NQ, o calcário dolomítico e o silicato de cálcio e magnésio tiveram menor destaque na disponibilidade de magnésio do que para o LVd e NVe.
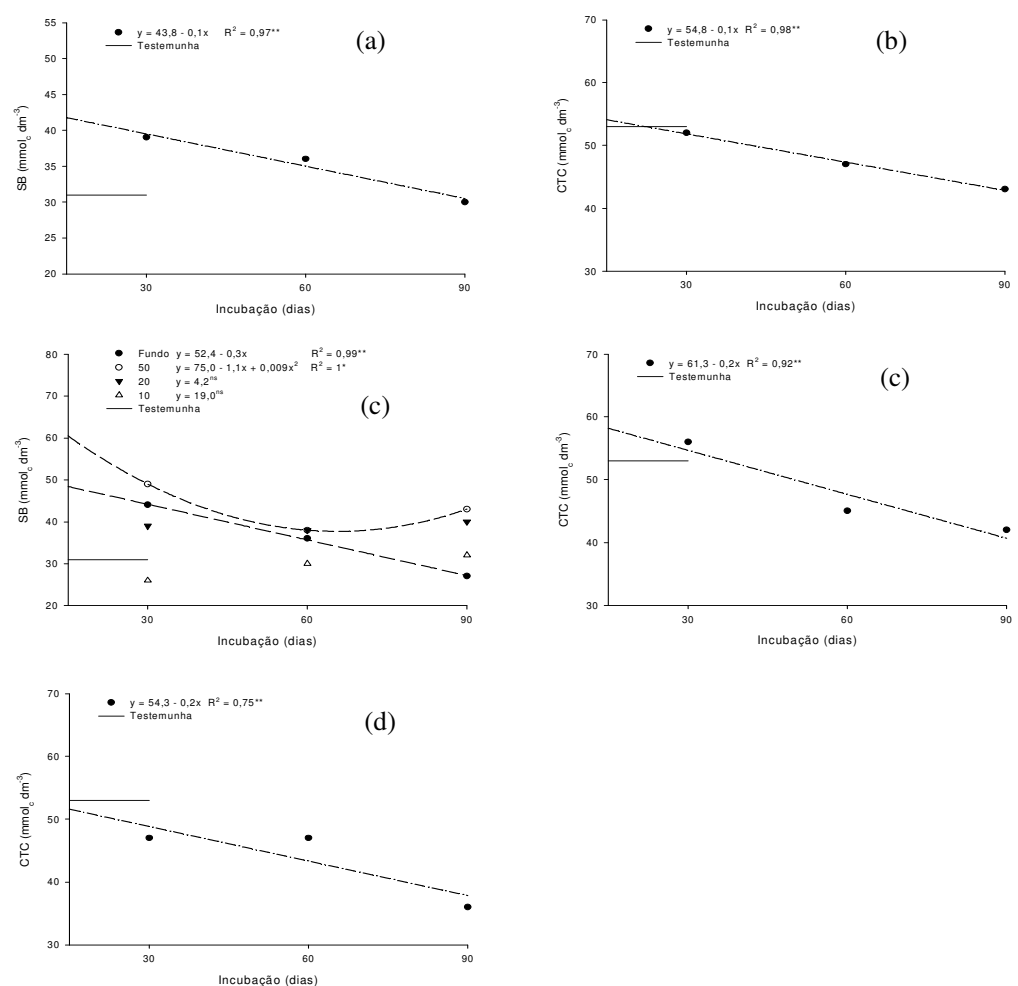

Figura 15. Valores de SB e CTC do Neossolo Quartzarênico (NQ) em função de períodos de incubação de escória (a), silicato de cálcio (b), silicato de cálcio e magnésio (c) e calcário calcítico (d). * e ** significativos a $5 \%$ e $1 \%$ de probabilidade, respectivamente. 
A fração granulométrica $2,0 \mathrm{~mm}$ praticamente não disponibilizou magnésio, apenas o calcário dolomítico aos trinta e sessenta dias é que proporcionou acréscimos mais significativos, mesmo assim o teor obtido por essa granulometria ficou bem distante dos teores das demais, (Tabelas 16 e 17). A granulometria $0,84 \mathrm{~mm}$ aos trinta dias também proporcionou pequenos acréscimos no teor de magnésio.

Os períodos de incubação com a aplicação da escória e do silicato de cálcio influenciou significativamente o teor de magnésio (Figura 12). Ocorreu diminuição no teor de magnésio com a incubação destes corretivos.

A interação períodos de incubação e granulometrias foi significativa no teor de cálcio e de magnésio com a aplicação do silicato de cálcio e magnésio, e o período de incubação influenciou o teor de cálcio e teor de magnésio com a aplicação da wollastonita (Figura 13). Para o teor de magnésio também ocorreu interação significativa quando aplicado o silicato de cálcio e calcário dolomítico (Figura 13).

O teor de magnésio diminuiu com a incubação, chegando aos noventa dias com teores menores do que os encontrados aos trinta dias. $\mathrm{O}$ resultado aos noventa dias com a aplicação da granulometria $2,0 \mathrm{~mm}$ chegou a ser inferior ao encontrado nas condições iniciais do solo.

Analisando as médias obtidas (Tabelas 16, 17 e 18) verifica-se que os valores da SB, CTC e V\% foram superiores na granulometria $0,30 \mathrm{~mm}$ em relação às demais, mas que esta granulometria foi significativamente igual à granulometria $<0,30 \mathrm{~mm}$. Esta superioridade da granulometria $0,30 \mathrm{~mm}$ em relação às demais granulometrias também ocorreu para os teores de cálcio e magnésio.

O resultado da comparação dos corretivos com a wollastonita aos 30 , 60 e 90 dias de incubação está na Tabela 19.

A aplicação da wollastonita proporcionou pH superior ao planejado, 5,5. Diferiu do silicato de cálcio e dos calcários dolomítico e calcítico apenas na primeira amostragem (30 dias de incubação), nos demais períodos não ocorreu diferença significativa entre os corretivos na alteração do $\mathrm{pH}$.

Para os teores de cálcio aos trinta e sessenta dias de incubação não verificou-se diferença entre os corretivos. Já aos noventas dias ocorreu diferença significativa, sendo a wollastonita semelhante a escória e diferente dos demais corretivos. 
A wollastonita alterou o teor de magnésio do solo, que diferiu apenas do silicato de cálcio e magnésio e do calcário dolomítico aos sessenta e noventa dias de incubação.

Tabela 19 - Atributos químicos do Neossolo Quartzarênico (NQ) em função da aplicação da fração granulométrica $<0,30 \mathrm{~mm}$ (peneira fundo) dos corretivos.

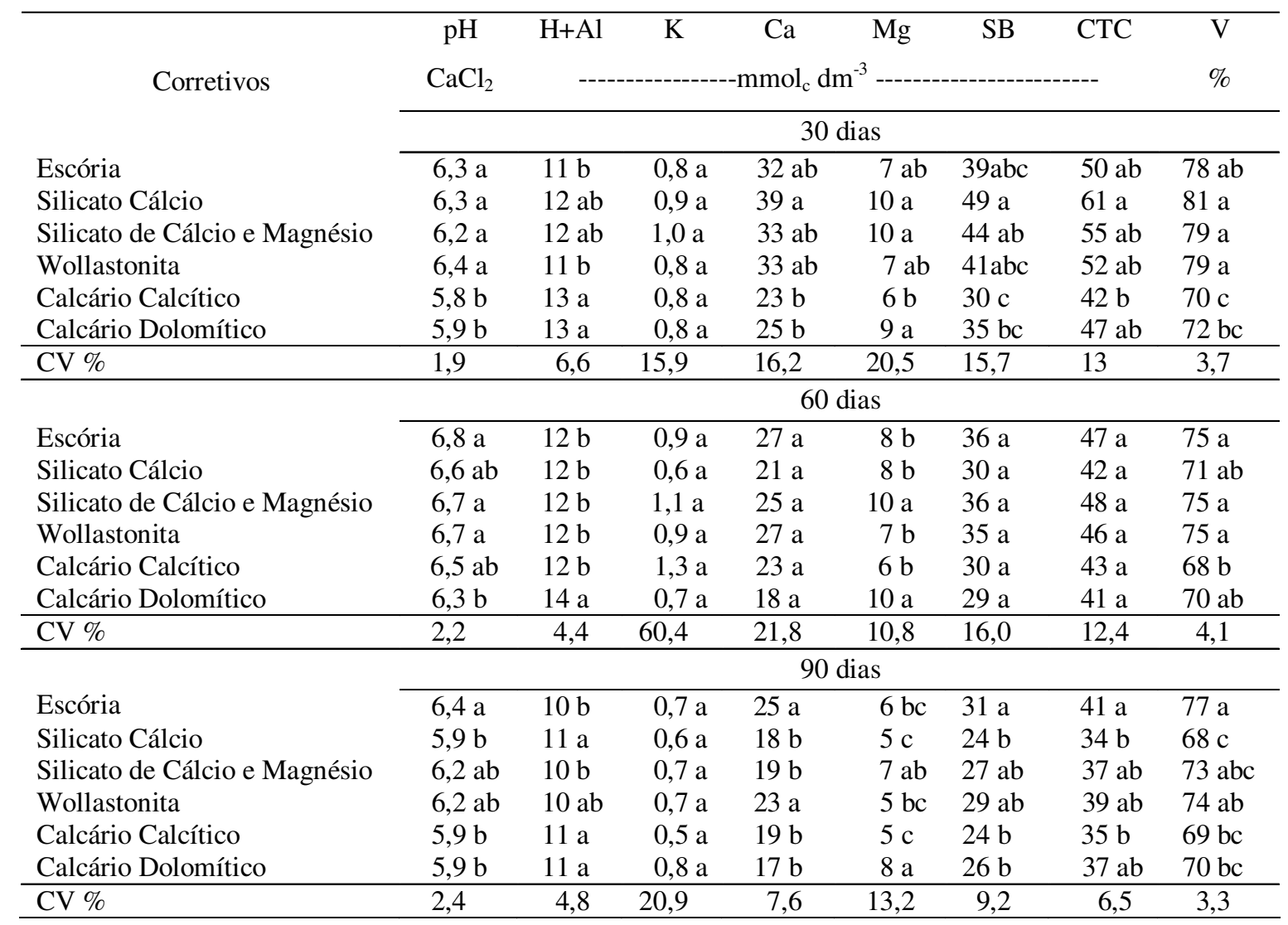

Médias seguidas de mesma letra não diferem entre si pelo teste de Tukey a $5 \%$ de probabilidade.

Para a SB e CTC verifica-se que a wollastonita não diferiu dos corretivos em todos os períodos, e para o V\% diferiu apenas dos calcários e do silicato de cálcio aos noventas dias de incubação. 


\subsubsection{Eficiência relativa de reatividade das frações granulométricas dos materiais corretivos da acidez dos solos}

A eficiência relativa das frações granulométricas dos corretivos variou em função dos corretivos de acidez e foi influenciada pelo tipo de solo (Tabela 20), fato também verificado por Bellingieri et al. (1989) e Alcarde et al. (1989), estudando a eficiência granulométrica de calcários.

Para um mesmo corretivo verificou-se grande mudança na eficiência relativa de suas frações granulométricas em função do solo, por isso considera-se de fundamental importância o estudo em solos com características químicas e físicas distintas, a fim de se obter uma media adequada para estimar a taxa de reatividade das partículas dos corretivos.

Tabela 20. Eficiência relativa (ER) de reatividade das frações granulométricas dos materiais corretivos de acidez do solo, calculada após 90 dias de incubação.

\begin{tabular}{clrrrr}
\hline \multirow{2}{*}{ Solos } & \multicolumn{1}{c}{ Corretivos } & \multicolumn{3}{c}{ Granulometrias $(\mathrm{mm})$} \\
\cline { 3 - 6 } & \multicolumn{1}{c}{ ER (\%) } & $<0,30$ & 0,30 & 0,84 & 2,0 \\
\hline \multirow{3}{*}{ Latossolo Vermelho distrófico } & Escória & 100 & 89 & 67 & 28 \\
& Silicato de cálcio & 100 & 89 & 106 & 94 \\
& Silicato de cálcio e magnésio & 111 & 106 & 94 & 72 \\
& Wollastonita & 83 & --- & --- & --- \\
& Calcário dolomítico & 100 & 83 & 78 & 17 \\
& Calcário calcítico & 100 & 78 & 39 & 6 \\
\hline \multirow{3}{*}{ Nitossolo Vermelho eutrófico } & Escória & 106 & 133 & 144 & 56 \\
(NVe) & Silicato de cálcio & 94 & 72 & 139 & 89 \\
& Silicato de cálcio e magnésio & 106 & 117 & 128 & 150 \\
& Wollastonita & 106 & --- & --- & --- \\
& Calcário dolomítico & 100 & 100 & 83 & 22 \\
& Calcário calcítico & 111 & 100 & 83 & 28 \\
\hline \multirow{2}{*}{ Neossolo Quartzarênico } & Escória & 133 & 147 & 140 & 7 \\
(NQ) & Silicato de cálcio & 100 & 180 & 140 & 107 \\
& Silicato de cálcio e magnésio & 120 & 133 & 173 & 133 \\
& Wollastonita & 120 & --- & --- & --- \\
& Calcário dolomítico & 100 & 113 & 120 & 60 \\
& Calcário calcítico & 100 & 107 & 87 & 53 \\
\hline
\end{tabular}


Para o LVd o aumento na eficiência relativa de reatividade das frações granulométricas, exceto para o silicato de cálcio ocorreu com a diminuição do tamanho das partículas (Tabela 20).

$\mathrm{O}$ mesmo fato não foi ocorreu para o $\mathrm{NVe}$ e NQ, a eficiência relativa das frações granulométricas dos corretivos para estes solos foi bem superior à obtida para o LVd. Para o NVe e NQ observou-se maior eficiência relativa das frações granulométricas de $0,30 \mathrm{~mm}$ e $0,84 \mathrm{~mm}$ em relação às demais frações para alguns corretivos. Ainda teve-se o silicato de cálcio e magnésio para o NVe que na granulometria 2,0 $\mathrm{mm}$ teve maior eficiência relativa que as demais frações granulométricas.

Independente do solo analisado verifica-se que a eficiência relativa de reatividade das frações granulométricas dos silicatos foi superior a do calcário, principalmente para as partículas de maior tamanho. Estes resultados mostraram-se discordantes dos obtidos por Prado et al. (2004) que encontraram taxas de reatividade para a escória próximas às vigentes pela legislação brasileira para calcários. A divergência entre os resultados deve-se a composição química das escórias, que é influenciada pela variação na composição química do minério de ferro utilizado como matéria prima em uma indústria siderúrgica, além do tipo de refratário usado nas paredes do forno (PRADO et al., 2001).

Outro fator importante é o tipo de resfriamento do material no momento de saída do forno, que pode ser ao ar ou por jatos de água chamado de "quenching". A forma de resfriamento interfere na qualidade do material; se a escória não receber "quenching", ocorre maior recristalização dos seus constituintes, o que pode reduzir a solubilidade dos seus compostos quando adicionado ao solo e conseqüentemente pode influenciar a reatividade do material (PRADO et al., 2001).

Desta forma, pode-se inferir que no processo de resfriamento da escória utilizada neste trabalho evitou-se a formação de materiais cristalizados e, portanto conferiu maior reatividade a este material. Por isto torna-se necessário o conhecimento da origem do material para melhor entendimento de suas reações no solo.

$\mathrm{Na}$ Tabela 21 estão as médias de eficiência relativa de reatividade das frações granulométricas para cada corretivo, considerando os três solos. Verifica-se semelhança entre os calcários que tiveram com a diminuição das partículas a eficiência relativa aumentada, já para os silicatos o resultado foi bem diferente. Para o silicato de cálcio e 
o silicato de cálcio e magnésio o maior valor de eficiência relativa foi obtido para a granulometria $0,84 \mathrm{~mm}$, seguido da granulometria $0,30 \mathrm{~mm}$. O silicato de cálcio e magnésio teve a maior eficiência granulométrica com a granulometria $0,84 \mathrm{~mm}$, sendo que a granulometria $<0,30 \mathrm{~mm}$ teve eficiência relativa menor que as demais granulometrias.

Tabela 21. Média da eficiência relativa (ER) das frações granulométricas dos materiais corretivos de acidez considerando os três solos

\begin{tabular}{lrrrr}
\hline \multirow{2}{*}{ Corretivos } & \multicolumn{4}{c}{ Granulometrias (mm) } \\
& $<0,30$ & 0,30 & 0,84 & 2,0 \\
\hline & & & ER (\%) & \\
Escória & 113 & 123 & 117 & 30 \\
Silicato de cálcio & 98 & 114 & 128 & 97 \\
Silicato de cálcio e magnésio & 112 & 119 & 132 & 118 \\
Wollastonita & 103 & ----- & ---- & ---- \\
Calcário dolomítico & 100 & 99 & 94 & 33 \\
Calcário calcítico & 104 & 95 & 70 & 29 \\
\hline
\end{tabular}

Para os calcários o aumento da reatividade ocorreu com a diminuição do tamanho das partículas e é explicado pela baixa solubilidade do calcário que faz com que a velocidade de neutralização da acidez dependa da área de contato entre o corretivo e o solo. Quanto menor a granulometria do calcário mais rápida é a reação de neutralização (VERLENGIA e GARGANTINI, 1972). Entretanto para os silicatos pode-se inferir que outros fatores contribuíram para aumentar a velocidade de neutralização da acidez, além do tamanho das partículas que favorecem a área de contato corretivo/solo. Supõe-se que a presença de poros nestes materiais permitiu a entrada de água, conferindo maior velocidade de dissolução, assim, as partículas de maior dimensão tiveram seu tamanho reduzido com conseqüente aumento na superfície especifica e, portanto, da ação corretiva no solo.

A wollastonita teve reatividade próxima a 100; apenas para o solo LVd a reatividade foi inferior.

Dentre os corretivos, os silicatos apresentaram as maiores taxas de eficiência relativa em todas as frações granulométricas. Para todos os corretivos os valores de eficiência das partículas foram superiores às determinadas pela legislação brasileira. Porém foi 
para os silicatos que se verificou maior diferença entre as taxas calculadas e as taxas determinadas pela legislação brasileira (Tabela 21).

Com a média da eficiência relativa de reatividade (Tabela 21), e a composição granulométrica (Tabela 2) de cada corretivo foi possível calcular a reatividade dos corretivos pela equação: $\% \mathrm{RE}=\% \mathrm{~F}_{10} \times \mathrm{Y}+\% \mathrm{~F}_{10-20} \times \mathrm{Y}+\% \mathrm{~F}_{20-50} \times \mathrm{Y}+\% \mathrm{~F}_{50} \times \mathrm{Y}$

Sendo:

$\% \mathrm{~F}_{10}=$ percentual de produto que ficou retido na peneira $\mathrm{n}^{\circ} 10$;

$\% \mathrm{~F}_{10-20}=$ percentual de produto que passou pela peneira $\mathrm{n}^{\circ} 10$ e ficou retido na peneira $\mathrm{n}^{\circ} 20$;

$\% \mathrm{~F}_{20-50}=$ percentual de produto que passou pela peneira $\mathrm{n}^{\circ} 20$ e ficou retido na peneira $\mathrm{n}^{\circ} 50$;

e $\mathrm{F}_{50}=$ percentual de produto que passou pela peneira $\mathrm{n}^{\circ} 50$.

Os valores de Y foram substituídos pelos valores de eficiência relativa para cada corretivo dividido por 100. O Poder Relativo de Neutralização Total (PRNT) foi obtido pela equação: $\mathrm{PRNT}=(\mathrm{PN} \times \mathrm{RE}) / 100$.

Os silicatos tiveram maior reatividade (RE) do que os calcários (Tabela 22). Quando os corretivos foram analisados pela metodologia proposta para calcários os valores de RE, PN e consequentemente PRNT dos silicatos foram menores em relação aos calcários. No entanto quando se compara estes valores de RE obtidos em laboratório com os valores de RE obtidos pelo método da incubação nota-se superioridade nos valores obtidos pelo ultimo método, principalmente para os silicatos, para os calcários a diferença foi mínima. Assim, pode se concluir que a metodologia empregada para calcários não deve ser a mesma para os silicatos.

O maior valor de reatividade confere aos silicatos maiores valores de PRNT e isso faz com que a dose a ser aplicada seja reduzida. Com base nessa afirmação, o experimento 3 foi conduzido com a finalidade de verificar se a eficiência relativa de reatividade das frações granulométricas obtidas no experimento 2 realmente poderiam ser consideradas no calculo do PRNT para prática da calagem proporcionando adequado desenvolvimento das plantas. 
Tabela 22. Reatividade (RE), Poder de Neutralização (PN) e Poder Relativo de Neutralização Total (PRNT) dos corretivos de acidez do solo.

\begin{tabular}{lccr}
\hline \multicolumn{1}{c}{ Corretivo } & RE & PN* & PRNT \\
\hline Escória & 116,7 & 71 & 82,9 \\
Silicato de cálcio & 106,8 & 78 & 83,3 \\
Silicato de cálcio e magnésio & 116,6 & 87 & 101,4 \\
Wollastonita & 103,0 & 60 & 61,8 \\
Calcário Dolomítico & 99,7 & 105 & 104,7 \\
Calcário Calcítico & 102,5 & 96 & 98,4 \\
\hline
\end{tabular}

*Obtido em laboratório

\subsection{Experimento 3}

\subsubsection{Latossolo Vermelho distrófico (LVd)}

\subsubsection{Atributos químicos do solo}

Houve diferença significativa entre os tratamentos no valor de $\mathrm{pH}$; $\mathrm{P}$; H+Al; Ca; Mg; SB e V\%, obtidos após 30 dias de incubação (Tabela 23).

$\mathrm{O}$ valor de $\mathrm{pH}$ foi maior com a aplicação da escória e da wollastonita, seguido do calcário dolomítico, e do silicato de cálcio e magnésio todos calculados com PRNT laboratório, os quais não apresentaram diferença significativa entre si e refletiram de forma direta na menor acidez potencial o que é justificado pelas doses serem mais elevadas para o cálculo com o PRNT laboratório em relação ao PRNT experimento.

A aplicação do silicato de cálcio praticamente não corrigiu a acidez do solo, que teve $\mathrm{pH}$ 4,6 e a acidez potencial em torno de $50 \mathrm{mmol}_{\mathrm{c}} \mathrm{dm}^{-3}$, valores próximos às condições iniciais do solo.

O teor de P foi elevado, considerado alto a muito alto (RAIJ et al., 1996). Apenas o silicato de cálcio e magnésio 2 diferiu dos demais tratamentos, atingindo o menor teor de $\mathrm{P}$. 
Tabela 23 - Resultados das análises químicas do Latossolo Vermelho distrófico (LVd) em função dos tratamentos após 30 dias de incubação.

\begin{tabular}{|c|c|c|c|c|c|c|c|c|c|}
\hline Tratamentos & $\mathrm{pH}$ & $\mathrm{P}$ & $\mathrm{H}+\mathrm{Al}$ & $\mathrm{K}$ & $\mathrm{Ca}$ & $\mathrm{Mg}$ & SB & CTC & $\mathrm{V}$ \\
\hline & $\mathrm{CaCl}_{2}$ & $\mathrm{mg} \mathrm{dm} \mathrm{m}^{-3}$ & & --- & -----mm & $\mathrm{dm}^{-3}$ & & --- & $\%$ \\
\hline Escória 1 & $6,0 \mathrm{a}$ & $66 \mathrm{ab}$ & $23 \mathrm{c}$ & $3,5 \mathrm{a}$ & $47 \mathrm{a}$ & $10 \mathrm{bc}$ & $60 \mathrm{a}$ & $84 \mathrm{a}$ & $72 \mathrm{a}$ \\
\hline Escória 2 & $5,4 \mathrm{~b}$ & $81 \mathrm{ab}$ & $31 \mathrm{~b}$ & $3,7 \mathrm{a}$ & $35 \mathrm{abc}$ & 8 bcd & $46 \mathrm{a}$ & $79 \mathrm{a}$ & $58 \mathrm{bc}$ \\
\hline Silicato de cálcio 1 & $4,6 \mathrm{c}$ & $67 \mathrm{ab}$ & $46 \mathrm{a}$ & $3,5 \mathrm{a}$ & $12 \mathrm{~d}$ & $2 \mathrm{e}$ & $18 \mathrm{~b}$ & $64 \mathrm{a}$ & $28 \mathrm{~d}$ \\
\hline Silicato de cálcio 2 & $4,6 \mathrm{c}$ & $61 \mathrm{ab}$ & $50 \mathrm{a}$ & $3,9 \mathrm{a}$ & $15 \mathrm{~d}$ & 3 de & $21 \mathrm{~b}$ & $71 \mathrm{a}$ & $29 \mathrm{~d}$ \\
\hline Silicato de cálcio e magnésio 1 & $5,8 \mathrm{a}$ & $69 \mathrm{ab}$ & $26 \mathrm{bc}$ & $3,1 \mathrm{a}$ & $38 \mathrm{abc}$ & $13 \mathrm{ab}$ & $54 \mathrm{a}$ & $80 \mathrm{a}$ & $68 \mathrm{abc}$ \\
\hline Silicato de cálcio e magnésio 2 & $5,4 \mathrm{~b}$ & $57 \mathrm{c}$ & $31 \mathrm{~b}$ & $3,3 \mathrm{a}$ & $26 \mathrm{~cd}$ & $9 \mathrm{bc}$ & $38 \mathrm{ab}$ & $68 \mathrm{a}$ & $55 \mathrm{c}$ \\
\hline Wollastonita 1 & $6,0 \mathrm{a}$ & $83 \mathrm{a}$ & $23 \mathrm{c}$ & $3,8 \mathrm{a}$ & $45 \mathrm{ab}$ & 7 cde & $56 a$ & $79 \mathrm{a}$ & $71 \mathrm{ab}$ \\
\hline Calcário dolomítico 1 & $5,8 \mathrm{a}$ & $77 \mathrm{ab}$ & $25 \mathrm{c}$ & $4,1 \mathrm{a}$ & 28 bcd & $18 \mathrm{a}$ & $49 \mathrm{a}$ & $74 \mathrm{a}$ & $67 \mathrm{abc}$ \\
\hline $\mathrm{CV}(\%)$ & 2,9 & 15,6 & 8,2 & 20,9 & 24,4 & 25,5 & 23,1 & 13,3 & 10,1 \\
\hline
\end{tabular}

Médias seguidas de mesma letra não diferem entre si pelo teste de Tukey a 5\% de probabilidade. 1: dose calculada a partir do PRNT laboratório; 2: dose calculada a partir do PRNT experimento.

A escória 1, a wollastonita e o silicato de cálcio e magnésio 1 foram os que proporcionaram maiores teores de cálcio no solo. A aplicação da escória com a dose PRNT experimento teve bons resultados, a qual proporcionou teor de cálcio superior ao obtido com aplicação do calcário. Já para o magnésio os maiores teores foram obtidos com a aplicação do calcário dolomítico, seguido do silicato de cálcio e magnésio 1.

Verifica-se para um mesmo corretivo que o cálculo da dose baseado no PRNT experimento ou em laboratório não diferiu na disponibilidade de cálcio, magnésio e consequentemente no valor de soma de bases do solo (Tabela 23). Entretanto esteve-se sempre superior o PRNT laboratório devido à sua maior dose.

Quando se compara as duas formas de cálculo nos componentes da acidez do solo, considerando $\mathrm{pH}, \mathrm{H}+\mathrm{Al}$, e V\% obteve-se comportamento distinto entre elas, sendo que a dose calculada com o PRNT experimento ficou bem distante dos níveis desejados.

A saturação por bases desejada, $80 \%$, não foi alcançada pela aplicação dos tratamentos; os valores mais próximos foram obtidos com a aplicação da escória 1 (72\%) e wollastonita (71\%) seguidos pelo silicato de cálcio e magnésio $1(68 \%)$ e do calcário (67\%), estes tratamentos não tiveram diferenças significativas entre si (Tabela 23). Resultado semelhante foi obtido por Prado e Natale (2004) com a aplicação de escória de siderurgia ferrocromo, onde se aplicou as doses: zero; metade; uma vez; uma vez e meia e duas vezes a dose necessária para elevar a saturação por bases a $80 \%$, entretanto a dose para elevar o V\% a 80 , alcançou apenas 66. 
De acordo com Prado e Fernandes (2000) a eficiência da escória de siderurgia baseado no poder de neutralização adotado para o calcário não apresentou comportamento satisfatório para estimar a necessidade de produto para a correção da acidez de um Latossolo Vermelho e um Neossolo Quartzarênico. Fato que também pode ser considerado neste experimento, para que os silicatos não alcançassem a saturação por bases de $80 \%$, além disto, o curto tempo de incubação dos corretivos, que foi de 30 dias pode não ter sido suficiente para a reação dos corretivos, considerando que para os demais experimentos o período adotado foi sempre de 90 dias.

No caso dos micronutrientes, os tratamentos só influenciaram o teor de Fe e de Mn (Tabela 24). Verifica-se maior teor de Fe no tratamento com silicato de cálcio, o que é explicado pelo aumento da solubilidade desse micronutriente em valores de $\mathrm{pH}$ menores (Tabela 23).

Tabela 24 - Resultados das análises de micronutrientes do Latossolo Vermelho distrófico (LVd) em função dos tratamentos após 30 dias de incubação.

\begin{tabular}{lccccc}
\hline \multicolumn{1}{c}{ Tratamentos } & $\mathrm{B}$ & $\mathrm{Cu}$ & $\mathrm{Fe}$ & $\mathrm{Mn}$ & $\mathrm{Zn}$ \\
\hline & -------------- \\
Escória 1 & $0,80 \mathrm{a}$ & $0,9 \mathrm{a}$ & $33 \mathrm{~b}$ & $11,3 \mathrm{a}$ & $2,0 \mathrm{a}$ \\
Escória 2 & $0,69 \mathrm{a}$ & $0,9 \mathrm{a}$ & $36 \mathrm{ab}$ & $9,2 \mathrm{a}$ & $2,6 \mathrm{a}$ \\
Silicato de cálcio 1 & $0,66 \mathrm{a}$ & $1,2 \mathrm{a}$ & $52 \mathrm{a}$ & $1,5 \mathrm{~b}$ & $3,4 \mathrm{a}$ \\
Silicato de cálcio 2 & $0,67 \mathrm{a}$ & $1,3 \mathrm{a}$ & $44 \mathrm{ab}$ & $2,9 \mathrm{~b}$ & $3,2 \mathrm{a}$ \\
Silicato de cálcio e magnésio 1 & $0,69 \mathrm{a}$ & $0,9 \mathrm{a}$ & $32 \mathrm{~b}$ & $4,1 \mathrm{~b}$ & $2,0 \mathrm{a}$ \\
Silicato de cálcio e magnésio 2 & $0,75 \mathrm{a}$ & $1,0 \mathrm{a}$ & $35 \mathrm{ab}$ & $3,0 \mathrm{~b}$ & $1,6 \mathrm{a}$ \\
Wollastonita 1 & $0,75 \mathrm{a}$ & $1,2 \mathrm{a}$ & $29 \mathrm{~b}$ & $0,8 \mathrm{~b}$ & $1,6 \mathrm{a}$ \\
Calcário dolomítico 1 & $0,80 \mathrm{a}$ & $0,9 \mathrm{a}$ & $32 \mathrm{~b}$ & $1,0 \mathrm{~b}$ & $1,7 \mathrm{a}$ \\
\hline CV $(\%)$ & 17,1 & 17,5 & 20,53 & 33,4 & 4,6 \\
\hline
\end{tabular}

Médias seguidas de mesma letra não diferem entre si pelo teste de Tukey a 5\% de probabilidade. 1: dose calculada a partir do PRNT laboratório; 2: dose calculada a partir do PRNT experimento.

O teor de manganês foi bem elevado com a aplicação da escória, a qual diferiu dos demais tratamentos. A escória contém em sua constituição química diversos óxidos, dentre eles o manganês (Prado et al., 2001), deste modo, a concentração deste óxido em sua composição pode ter influenciado a concentração no solo.

$\mathrm{Na}$ tabela 25 está o resultado da análise química do solo após o primeiro corte da alfafa (90 dias após a aplicação dos tratamentos), considerada a segunda 
amostragem de solo. Os tratamentos diferiram entre si significativamente nos valores de $\mathrm{pH}$; $\mathrm{H}+\mathrm{Al} ; \mathrm{Ca} ; \mathrm{Mg} ; \mathrm{SB}$ e V\%.

Percebe-se semelhança na variação dos resultados obtidos, tanto na primeira amostragem quanto na segunda, onde se destacou a aplicação da escória 1 , silicato de cálcio e magnésio 1, wollastonita e calcário dolomítico.

$\mathrm{O}$ pH do solo diminuiu em relação à primeira amostragem com conseqüente elevação da acidez potencial. Observa-se que o valor de $\mathrm{pH}$ diminuiu, mas os corretivos tiveram mesmo comportamento nas duas amostragens com superioridade para a escória, calcário dolomítico, wollastonita e silicato de cálcio e magnésio todos calculados com PRNT laboratório.

Tabela 25 - Resultados das análises químicas do Latossolo Vermelho distrófico (LVd) em função dos tratamentos após o primeiro cultivo da alfafa, 90 dias após a incubação.

\begin{tabular}{|c|c|c|c|c|c|c|c|c|c|}
\hline Tratamentos & $\mathrm{pH}$ & $\mathrm{P}$ - resina & $\mathrm{H}+\mathrm{Al}$ & $\mathrm{K}$ & $\mathrm{Ca}$ & $\mathrm{Mg}$ & SB & CTC & $\mathrm{V}$ \\
\hline & $\mathrm{CaCl}_{2}$ & $\mathrm{mg} \mathrm{dm}^{-3}$ & --- & ------- & $-\mathrm{mmol}_{\mathrm{c}}$ & $n^{-3}-$ & --------- & & $\%$ \\
\hline Escória 1 & $5,5 \mathrm{a}$ & $41 \mathrm{a}$ & $29 \mathrm{~cd}$ & $1,5 \mathrm{a}$ & $30 \mathrm{a}$ & $6 \mathrm{bc}$ & $36 \mathrm{ab}$ & $66 \mathrm{a}$ & $54 \mathrm{a}$ \\
\hline Escória 2 & $4,9 \mathrm{c}$ & $45 \mathrm{a}$ & $43 \mathrm{~b}$ & $0,9 \mathrm{a}$ & $20 \mathrm{ab}$ & $4 \mathrm{bcd}$ & $24 \mathrm{abc}$ & $67 \mathrm{a}$ & $36 \mathrm{~b}$ \\
\hline Silicato de cálcio 1 & $4,5 \mathrm{~d}$ & $47 \mathrm{a}$ & $57 \mathrm{a}$ & $1,0 \mathrm{a}$ & $8 \mathrm{~b}$ & $1 \mathrm{~d}$ & $11 \mathrm{c}$ & $68 \mathrm{a}$ & $16 \mathrm{c}$ \\
\hline Silicato de cálcio 2 & $4,4 \mathrm{~d}$ & $36 a$ & $62 \mathrm{a}$ & $1,1 \mathrm{a}$ & $7 \mathrm{~b}$ & $1 \mathrm{~d}$ & $10 \mathrm{c}$ & $72 \mathrm{a}$ & $14 \mathrm{c}$ \\
\hline Silicato de cálcio e magnésio 1 & $5,3 \mathrm{ab}$ & $31 \mathrm{a}$ & 33 bcd & $0,6 \mathrm{a}$ & $26 \mathrm{a}$ & $8 \mathrm{~b}$ & $33 a b$ & $67 \mathrm{a}$ & $50 \mathrm{ab}$ \\
\hline Silicato de cálcio e magnésio 2 & $5,0 \mathrm{bc}$ & $32 \mathrm{a}$ & $39 \mathrm{bc}$ & $0,7 \mathrm{a}$ & $17 \mathrm{ab}$ & $5 \mathrm{bcd}$ & $22 \mathrm{bc}$ & $61 \mathrm{a}$ & $36 \mathrm{~b}$ \\
\hline Wollastonita 1 & $5,4 \mathrm{ab}$ & $38 \mathrm{a}$ & $30 \mathrm{~cd}$ & $0,7 \mathrm{a}$ & $26 \mathrm{a}$ & $3 \mathrm{bcd}$ & $30 \mathrm{ab}$ & $60 \mathrm{a}$ & $50 \mathrm{ab}$ \\
\hline Calcário dolomítico 1 & $5,5 \mathrm{a}$ & $45 \mathrm{a}$ & $29 \mathrm{~d}$ & $1,0 \mathrm{a}$ & $24 \mathrm{a}$ & $15 \mathrm{a}$ & $39 \mathrm{a}$ & $69 \mathrm{a}$ & $57 \mathrm{a}$ \\
\hline $\mathrm{CV}(\%)$ & 3,2 & 28,2 & 10,5 & 60,0 & 29,5 & 37,0 & 28,3 & 10,6 & 19,2 \\
\hline
\end{tabular}

Os tratamentos não diferiram na disponibilidade de $\mathrm{P}$ e $\mathrm{K}$, e o teor destes nutrientes reduziu no segundo corte, assim como também verificado para o cálcio e o magnésio. A redução destes nutrientes se deve a extração pela planta no primeiro cultivo. Apesar da redução do teor de $\mathrm{P}$ e Ca estes nutrientes se mantiveram em níveis adequados no solo, entre médio a alto (RAIJ et al., 1996).

Da mesma maneira que ocorreu na primeira amostragem, os maiores teores de cálcio foram verificados com a aplicação da escória 1, wollastonita e silicato de cálcio e magnésio1. Para o magnésio apenas o calcário dolomítico manteve o teor próximo à primeira amostragem, considerado alto. Já com o silicato de cálcio e magnésio o teor reduziu bastante, passando ao teor considerado médio de acordo com Raij et al. (1996). 
A saturação por bases também teve seu valor reduzido, os tratamentos: escória 1 e o silicato de cálcio e magnésio 1, wollastonita e calcário não diferiram no valor da saturação por bases. Na primeira amostragem a escória alcançou o maior valor de V, 72 \%, (Tabela 23), entretanto na segunda amostragem esse valor passou para $52 \%$. Na segunda amostragem o maior valor de V\% foi obtido com a aplicação do calcário dolomítico (Tabela 25).

O silicato de cálcio não foi eficiente na correção da acidez do solo, e na disponibilidade de cálcio e magnésio nas duas amostragens (Tabelas 23 e 25).

\subsubsection{Variáveis da planta}

Os tratamentos diferiram significativamente na produção de matéria seca da parte aérea da alfafa, no primeiro e segundo corte (Tabela 26).

Tabela 26 - Matéria seca de parte aérea da alfafa, no primeiro corte $(\mathrm{C} 1)$ e no segundo corte (C2) em função dos tratamentos no Latossolo Vermelho distrófico (LVd).

\begin{tabular}{lcc}
\hline \multirow{2}{*}{ Tratamentos } & \multicolumn{2}{c}{ Matéria Seca (g por vaso) } \\
\cline { 2 - 3 } & $\mathrm{C} 1$ & $\mathrm{C} 2$ \\
\hline Escória 1 & $27,55 \mathrm{a}$ & $16,35 \mathrm{a}$ \\
Escória 2 & $25,50 \mathrm{ab}$ & $14,52 \mathrm{ab}$ \\
Silicato de cálcio 1 & $18,43 \mathrm{~cd}$ & $15,50 \mathrm{ab}$ \\
Silicato de cálcio 2 & $13,80 \mathrm{~d}$ & $13,77 \mathrm{ab}$ \\
Silicato de cálcio e magnésio 1 & $28,33 \mathrm{a}$ & $14,96 \mathrm{ab}$ \\
Silicato de cálcio e magnésio 2 & $22,63 \mathrm{abc}$ & $15,86 \mathrm{a}$ \\
Wollastonita 1 & $27,05 \mathrm{a}$ & $11,93 \mathrm{~b}$ \\
Calcário dolomítico 1 & $20,85 \mathrm{bc}$ & $12,94 \mathrm{ab}$ \\
\hline CV (\%) & 11,2 & 11,0 \\
\hline Mádias seguidas de mesma letra não diferem entre si pelo teste de Tukey a 5\% de probabilidade. 1: dose calculada a partir do PRNT \\
laboratório; 2: dose calculada a partir do PRNT experimento.
\end{tabular}

Para esta variável notou-se o mesmo efeito nos dois cortes, onde se teve maior produção de matéria seca da parte aérea com a aplicação da escória 1. Os silicatos, com exceção ao silicato de cálcio proporcionaram maior produção de matéria seca de alfafa em relação ao calcário dolomítico. A sequiência para os silicatos foi: escória 1, silicato de cálcio e magnésio 1 e wollastonita. Embora o cálculo com o PRNT experimento para estes 
corretivos teve menor produção, esta ainda foi maior do que a produção de matéria seca obtida com a aplicação do calcário dolomítico.

O silicato de cálcio foi o tratamento que proporcionou menor teor de matéria seca, devido sua aplicação não ter atingido níveis adequados de correção da acidez do solo e consequentemente de nutrientes para o desenvolvimento das plantas de alfafa.

Houve diferença significativa entre os tratamentos nos teores de N, K, $\mathrm{Ca}, \mathrm{Mg}, \mathrm{Mn}, \mathrm{Zn}$ e B na parte aérea da alfafa no primeiro corte (Tabela 27), e nos teores de P, $\mathrm{K}, \mathrm{Ca}, \mathrm{Mg}, \mathrm{Fe}, \mathrm{Mn}, \mathrm{Zn}$ no segundo corte (Tabela 28).

Tabela 27 - Teores médios de nutrientes na parte aérea de plantas de alfafa $\left(1^{\circ}\right.$ corte $)$ em função dos tratamentos aplicados no Latossolo Vermelho distrófico (LVd).

\begin{tabular}{|c|c|c|c|c|c|c|c|c|c|c|c|}
\hline Tratamentos & $\mathrm{N}$ & $P$ & $\mathrm{~K}$ & $\mathrm{Ca}$ & $\mathrm{Mg}$ & $S$ & $\mathrm{Cu}$ & $\mathrm{Fe}$ & $\mathrm{Mn}$ & $\mathrm{Zn}$ & B \\
\hline & \multicolumn{6}{|c|}{ 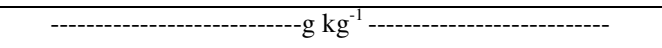 } & \multicolumn{5}{|c|}{ 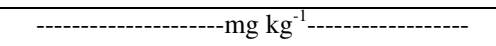 } \\
\hline Escória 1 & $25 \mathrm{~d}$ & $2,7 \mathrm{a}$ & $18 \mathrm{~d}$ & $20 \mathrm{ab}$ & $2,8 \mathrm{~d}$ & $1,9 \mathrm{a}$ & $8 \mathrm{a}$ & $84 \mathrm{a}$ & $147 \mathrm{ab}$ & $34 \mathrm{bc}$ & $74 \mathrm{ab}$ \\
\hline Escória 2 & $27 \mathrm{~cd}$ & $2,9 \mathrm{a}$ & $19 \mathrm{~d}$ & $21 \mathrm{a}$ & $3,0 \mathrm{~cd}$ & $1,9 \mathrm{a}$ & $7 \mathrm{a}$ & $92 \mathrm{a}$ & $159 \mathrm{a}$ & $49 \mathrm{~b}$ & $77 \mathrm{ab}$ \\
\hline Silicato de cálcio 1 & $38 \mathrm{ab}$ & $3,0 \mathrm{a}$ & $28 \mathrm{ab}$ & $20 \mathrm{ab}$ & $2,7 \mathrm{~d}$ & $2,3 \mathrm{a}$ & $7 \mathrm{a}$ & 99 a & $137 \mathrm{ab}$ & $69 \mathrm{a}$ & $74 \mathrm{ab}$ \\
\hline Silicato de cálcio 2 & $40 \mathrm{a}$ & $3,2 \mathrm{a}$ & $31 \mathrm{a}$ & $18 \mathrm{ab}$ & $2,7 \mathrm{~d}$ & $2,4 \mathrm{a}$ & $7 \mathrm{a}$ & $94 \mathrm{a}$ & $156 \mathrm{a}$ & $71 \mathrm{a}$ & $73 a b$ \\
\hline Silicato de cálcio e magnésio 1 & $27 \mathrm{~cd}$ & $3,1 \mathrm{a}$ & $19 \mathrm{~d}$ & $19 a b$ & $4,1 \mathrm{~b}$ & $2,1 \mathrm{a}$ & $8 \mathrm{a}$ & 98 a & $111 \mathrm{bc}$ & $33 \mathrm{bc}$ & $82 \mathrm{a}$ \\
\hline Silicato de cálcio e magnésio 2 & $31 \mathrm{~cd}$ & $3,2 \mathrm{a}$ & $20 \mathrm{~cd}$ & $17 a b$ & $3,8 \mathrm{bc}$ & $2,1 \mathrm{a}$ & $7 \mathrm{a}$ & $97 \mathrm{a}$ & $94 \mathrm{c}$ & $47 \mathrm{~b}$ & $73 \mathrm{ab}$ \\
\hline Wollastonita 1 & $26 \mathrm{~cd}$ & $3,0 \mathrm{a}$ & $21 \mathrm{~cd}$ & $21 \mathrm{a}$ & $2,4 \mathrm{~d}$ & $2,1 \mathrm{a}$ & $6 \mathrm{a}$ & $96 \mathrm{a}$ & $77 \mathrm{c}$ & $27 \mathrm{c}$ & $68 \mathrm{~b}$ \\
\hline Calcário dolomítico 1 & $32 \mathrm{bc}$ & $3,2 \mathrm{a}$ & $24 \mathrm{bc}$ & $15 \mathrm{~b}$ & $5,5 \mathrm{a}$ & $2,2 \mathrm{a}$ & $8 \mathrm{a}$ & $82 \mathrm{a}$ & $75 \mathrm{c}$ & $35 \mathrm{bc}$ & $68 \mathrm{~b}$ \\
\hline $\mathrm{CV}(\%)$ & 9,6 & 13,6 & 9,8 & 11,7 & 11,3 & 10,5 & 13,9 & 14,0 & 15,1 & 15,7 & 8,6 \\
\hline
\end{tabular}

$\mathrm{Na}$ avaliação do primeiro corte o maior teor de nitrogênio, potássio, e zinco foram obtidos com a aplicação do silicato de cálcio 1 e 2, os quais se encontram na faixa adequada para a alfafa (RAIJ et al.,1996).

Nesta mesma avaliação, os teores de cálcio foram próximos, e apenas a escória 1 diferiu do calcário dolomítico, sendo que o calcário proporcionou o menor teor de cálcio (Tabela 27). O menor teor de cálcio com a aplicação do calcário dolomítico se repetiu no segundo corte, e os silicatos não apresentaram diferenças significativas entre si, exceção feita apenas ao silicato de cálcio e magnésio e a wollastonita, a qual proporcionou o maior teor de cálcio na parte aérea da alfafa ( $27 \mathrm{~g} \mathrm{~kg}^{-1}$ ) (Tabela 28). 
Tabela 28 - Teores médios de nutrientes na parte aérea de plantas de alfafa ( $2^{\circ}$ corte) em função dos tratamentos aplicados no Latossolo Vermelho distrófico (LVd).

\begin{tabular}{|c|c|c|c|c|c|c|c|c|c|c|c|}
\hline Tratamentos & $\mathrm{N}$ & $\mathrm{P}$ & $\mathrm{K}$ & $\mathrm{Ca}$ & $\mathrm{Mg}$ & $S$ & $\mathrm{Cu}$ & $\mathrm{Fe}$ & $\mathrm{Mn}$ & $\mathrm{Zn}$ & B \\
\hline & \multicolumn{6}{|c|}{ 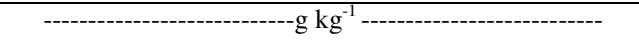 } & \multicolumn{5}{|c|}{---------------------'mg kg ${ }^{-1}$----------------- } \\
\hline Escória 1 & $17 \mathrm{a}$ & $3,7 \mathrm{ab}$ & $18 \mathrm{ab}$ & $25 \mathrm{ab}$ & $4,1 \mathrm{~b}$ & $3,3 \mathrm{a}$ & $12 \mathrm{a}$ & $368 \mathrm{a}$ & $275 \mathrm{a}$ & $77 \mathrm{ab}$ & $109 \mathrm{a}$ \\
\hline Escória 2 & $20 \mathrm{a}$ & $3,8 \mathrm{ab}$ & $17 \mathrm{~b}$ & $22 \mathrm{abc}$ & $3,8 \mathrm{bc}$ & $3,0 \mathrm{a}$ & $10 \mathrm{a}$ & $314 \mathrm{a}$ & $268 \mathrm{ab}$ & 98 a & $112 \mathrm{a}$ \\
\hline Silicato de cálcio 1 & $16 \mathrm{a}$ & $3,0 \mathrm{~b}$ & $19 \mathrm{ab}$ & $24 \mathrm{abc}$ & $2,7 \mathrm{c}$ & $2,5 \mathrm{a}$ & $10 \mathrm{a}$ & $361 \mathrm{a}$ & $191 \mathrm{bcd}$ & $95 \mathrm{a}$ & $103 \mathrm{a}$ \\
\hline Silicato de cálcio 2 & $18 \mathrm{a}$ & $3,1 \mathrm{~b}$ & $22 \mathrm{a}$ & $22 \mathrm{abc}$ & $2,8 \mathrm{bc}$ & $2,3 \mathrm{a}$ & 9 a & $383 \mathrm{a}$ & $227 \mathrm{abc}$ & 91 a & $106 \mathrm{a}$ \\
\hline Silicato de cálcio e magnésio 1 & $15 \mathrm{a}$ & $3,9 \mathrm{ab}$ & $17 \mathrm{~b}$ & $25 \mathrm{ab}$ & $6,2 \mathrm{a}$ & $3,2 \mathrm{a}$ & $11 \mathrm{a}$ & $286 \mathrm{a}$ & $201 \mathrm{abc}$ & $71 \mathrm{ab}$ & $115 \mathrm{a}$ \\
\hline Silicato de cálcio e magnésio 2 & $18 \mathrm{a}$ & $4,2 \mathrm{a}$ & $17 \mathrm{~b}$ & $21 \mathrm{bc}$ & $5,6 \mathrm{a}$ & $2,8 \mathrm{a}$ & $10 \mathrm{a}$ & $302 \mathrm{a}$ & $179 \mathrm{~cd}$ & $91 \mathrm{a}$ & $99 \mathrm{a}$ \\
\hline Wollastonita 1 & $18 \mathrm{a}$ & $3,7 \mathrm{ab}$ & $18 a b$ & $27 \mathrm{a}$ & $3,5 \mathrm{bc}$ & $3,1 \mathrm{a}$ & $11 \mathrm{a}$ & $439 \mathrm{a}$ & $154 \mathrm{~cd}$ & $70 \mathrm{ab}$ & $107 \mathrm{a}$ \\
\hline Calcário dolomítico 1 & $15 \mathrm{a}$ & $3,7 \mathrm{ab}$ & $19 a b$ & $18 \mathrm{~d}$ & $6,3 \mathrm{a}$ & $3,0 \mathrm{a}$ & $10 \mathrm{a}$ & $375 \mathrm{a}$ & $115 \mathrm{~d}$ & $57 \mathrm{~b}$ & $104 \mathrm{a}$ \\
\hline $\mathrm{CV}(\%)$ & 20,0 & 11,5 & 10,1 & 11,1 & 13,5 & 16,0 & 11,3 & 18,7 & 16,5 & 14,9 & 11,3 \\
\hline
\end{tabular}

Para o teor de magnésio, destacou-se a aplicação do calcário dolomítico seguido do silicato de cálcio e magnésio 1 e 2, nos dois cortes avaliados (Tabelas 27 e 28). Desta forma, confirma-se que o magnésio quantificado na análise química da escória realmente não estava em forma disponível, já que este magnésio não foi liberado nem para o solo e nem para a planta.

Os teores de potássio na parte aérea da alfafa, nos cortes avaliados, foram superiores com a aplicação do silicato de cálcio 2. Sendo que no primeiro corte o teor deste nutriente estava próximo ao considerado adequado para a alfafa, que é de $20-35 \mathrm{~g} \mathrm{~kg}^{-1}$ segundo Raij et al. (1996). O teor de potássio decresceu no segundo corte, e apenas o silicato de cálcio manteve o teor adequado.

O teor de manganês foi elevado, com valores superiores ao adequados para a alfafa com a aplicação dos tratamentos escória 1 e 2 , silicato de cálcio 1 e 2 e silicato de cálcio e magnésio 1, os quais não diferiram entre si na avaliação do primeiro corte (Tabela 27). No segundo corte ocorreu aumento no teor deste micronutriente, tendo todos os tratamentos teores considerados superiores ao adequado para a alfafa de acordo com Raij et al. (1996).

As doses 1 e 2 (PRNT laboratório e PRNT experimento, respectivamente) não diferiram entre si nos teores dos nutrientes, quando comparadas para um mesmo corretivo, nos dois cortes avaliados. 
Verifica-se pelas tabelas 27 e 28 que o teor de $\mathrm{P}, \mathrm{Ca}, \mathrm{Mg}, \mathrm{S}, \mathrm{Cu}, \mathrm{Fe}$, $\mathrm{Mn}, \mathrm{Zn}$ e B aumentou do primeiro para o segundo corte. O aumento nos teores destes nutrientes, deve-se ao efeito concentração, tendo em vista que, no segundo corte houve menor produção de matéria seca e diminuição no acúmulo dos nutrientes, exceção feita ao ferro, que teve seu acúmulo aumentado (Tabela 30).

Os valores de acúmulo dos nutrientes na parte aérea da alfafa obtidos com o primeiro corte e segundo corte estão nas Tabelas 29 e 30, respectivamente. Na avaliação do primeiro corte os tratamentos diferiram significativamente entre si no acúmulo de $\mathrm{P}, \mathrm{Ca}, \mathrm{Mg}, \mathrm{S}, \mathrm{Cu}, \mathrm{Fe}, \mathrm{Mn}, \mathrm{Zn}, \mathrm{B}$ e no segundo corte ocorreu diferenças significativas entre os tratamentos no acúmulo de $\mathrm{P}, \mathrm{K}, \mathrm{Ca}, \mathrm{Mg}, \mathrm{S}, \mathrm{Cu}, \mathrm{Mn}, \mathrm{Zn}$ e $\mathrm{B}$.

$\mathrm{O}$ acúmulo máximo de $\mathrm{P}$ foi de $87,3 \mathrm{mg}$ por vaso obtido com a aplicação do silicato de cálcio e magnésio 1 no primeiro corte, e este tratamento diferiu apenas do silicato de cálcio 1 e 2 . O acúmulo máximo de $\mathrm{P}$ no segundo corte também foi obtido com a aplicação do silicato de cálcio e magnésio, no entanto neste caso foi a dose 2. O menor acúmulo ocorreu com a aplicação do silicato de cálcio 2 em ambos os cortes.

Para o cálcio, no primeiro corte, os maiores acúmulos foram obtidos com a aplicação da wollastonita seguido da escória e silicato de cálcio e magnésio 1, verificase que o menor acúmulo foi com a aplicação do silicato de cálcio 2 e com o calcário dolomítico (Tabela 29). Já no segundo corte, o maior acúmulo foi verificado com a aplicação da escória 1; o silicato de cálcio 2 e o calcário dolomítico mantiveram-se com o menor acúmulo de cálcio (Tabela 30).

O calcário dolomítico e silicato de cálcio e magnésio destacaram-se no acúmulo de magnésio, com valores bem mais elevados que os demais tratamentos (Tabelas 29 e 30). 
Tabela 29 - Acúmulo médio de nutrientes na parte aérea de plantas de alfafa $\left(1^{\circ}\right.$ corte $)$ em função dos tratamentos aplicados no Latossolo Vermelho distrófico (LVd).

\begin{tabular}{|c|c|c|c|c|c|c|}
\hline Tratamentos & $\mathrm{N}$ & $\mathrm{P}$ & $\mathrm{K}$ & $\mathrm{Ca}$ & $\mathrm{Mg}$ & $S$ \\
\hline & & & $---m g$ pc & vaso ------ & & \\
\hline Escória 1 & 674,9 a & $73,7 \mathrm{ab}$ & $489,1 \mathrm{a}$ & $550,7 \mathrm{a}$ & 77,2 bc & $51,0 \mathrm{a}$ \\
\hline Escória 2 & $679,1 \mathrm{a}$ & $75,0 \mathrm{ab}$ & $475,9 \mathrm{a}$ & $515,2 \mathrm{a}$ & $74,3 \mathrm{bc}$ & $48,8 \mathrm{ab}$ \\
\hline Silicato de cálcio 1 & 703,7 a & $55,6 \mathrm{bc}$ & $520,2 \mathrm{a}$ & $362,7 \mathrm{~b}$ & $48,8 \mathrm{de}$ & $42,9 \mathrm{ab}$ \\
\hline Silicato de cálcio 2 & $551,1 \mathrm{a}$ & $44,4 \mathrm{c}$ & $421,6 \mathrm{a}$ & 243,6 c & $36,4 \mathrm{e}$ & $32,4 \mathrm{~b}$ \\
\hline Silicato de cálcio e magnésio 1 & 754,6 a & $87,3 \mathrm{a}$ & 540,6 a & $517,1 \mathrm{a}$ & $112,9 \mathrm{a}$ & $59,0 \mathrm{a}$ \\
\hline Silicato de cálcio e magnésio 2 & $701,5 \mathrm{a}$ & $72,4 \mathrm{ab}$ & $440,7 \mathrm{a}$ & $378,2 \mathrm{~b}$ & $85,0 \mathrm{~b}$ & $47,9 \mathrm{ab}$ \\
\hline Wollastonita 1 & 696,3 a & $81,1 \mathrm{ab}$ & 556,8 a & 570,8 a & $65,2 \mathrm{~cd}$ & 55,9 a \\
\hline Calcário dolomítico 1 & $670,6 \mathrm{a}$ & $65,3 \mathrm{abc}$ & $505,2 \mathrm{a}$ & $317,4 \mathrm{bc}$ & $113,7 \mathrm{a}$ & $45,3 \mathrm{ab}$ \\
\hline $\mathrm{CV}(\%)$ & 14,3 & 16,1 & 13,9 & 9,5 & 10,4 & 15,3 \\
\hline Tratamentos & $\mathrm{Cu}$ & $\mathrm{Fe}$ & $\mathrm{Mn}$ & $\mathrm{Zn}$ & \multicolumn{2}{|c|}{$\mathrm{B}$} \\
\hline & \multicolumn{6}{|c|}{ 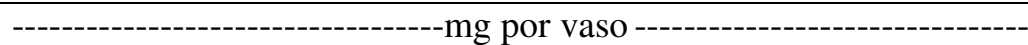 } \\
\hline Escória 1 & $0,21 \mathrm{a}$ & $2,32 \mathrm{ab}$ & $4,05 \mathrm{a}$ & $0,95 \mathrm{a}$ & \multicolumn{2}{|c|}{$2,03 \mathrm{ab}$} \\
\hline Escória 2 & $0,18 \mathrm{a}$ & $2,37 \mathrm{ab}$ & $3,99 \mathrm{a}$ & $1,24 \mathrm{a}$ & \multicolumn{2}{|c|}{$1,93 \mathrm{ab}$} \\
\hline Silicato de cálcio 1 & $0,12 \mathrm{bc}$ & $1,88 a b$ & $2,42 \mathrm{c}$ & $1,27 \mathrm{ab}$ & \multicolumn{2}{|c|}{$1,35 \mathrm{~cd}$} \\
\hline Silicato de cálcio 2 & $0,10 \mathrm{c}$ & $1,30 \mathrm{~b}$ & $2,09 \mathrm{~cd}$ & $0,98 \mathrm{ab}$ & \multicolumn{2}{|c|}{$1,00 \mathrm{~d}$} \\
\hline Silicato de cálcio e magnésio 1 & $0,22 \mathrm{a}$ & $2,83 \mathrm{a}$ & $3,05 \mathrm{~b}$ & $0,92 \mathrm{ab}$ & \multicolumn{2}{|c|}{2,28 a } \\
\hline Silicato de cálcio e magnésio 2 & $0,16 \mathrm{abc}$ & $2,23 a b$ & $2,08 \mathrm{~cd}$ & $1,06 \mathrm{ab}$ & \multicolumn{2}{|c|}{$1,62 \mathrm{bc}$} \\
\hline Wollastonita 1 & $0,17 \mathrm{ab}$ & $2,59 \mathrm{a}$ & $2,09 \mathrm{~cd}$ & $0,72 \mathrm{~b}$ & \multicolumn{2}{|c|}{$1,83 \mathrm{abc}$} \\
\hline Calcário dolomítico 1 & $0,16 \mathrm{abc}$ & $1,70 \mathrm{ab}$ & $1,55 \mathrm{~d}$ & $0,72 \mathrm{~b}$ & \multicolumn{2}{|c|}{$1,42 \mathrm{~cd}$} \\
\hline $\mathrm{CV}(\%)$ & 16,0 & 22,3 & 9,7 & 21,0 & \multicolumn{2}{|c|}{12,2} \\
\hline
\end{tabular}


Tabela 30 - Acúmulo médio de nutrientes na parte aérea de plantas de alfafa ( $2^{\circ}$ corte) em função dos tratamentos aplicados no Latossolo Vermelho distrófico (LVd).

\begin{tabular}{|c|c|c|c|c|c|c|}
\hline Tratamentos & $\mathrm{N}$ & $\mathrm{P}$ & $\mathrm{K}$ & $\mathrm{Ca}$ & $\mathrm{Mg}$ & $S$ \\
\hline Escória 1 & $276,8 \mathrm{a}$ & $60,1 \mathrm{a}$ & $287,5 \mathrm{a}$ & $406,2 \mathrm{a}$ & $65,4 b c$ & $53,3 \mathrm{a}$ \\
\hline Escória 2 & 283,7 a & $54,8 \mathrm{ab}$ & $243,2 \mathrm{ab}$ & $317,1 \mathrm{abc}$ & $54,9 \mathrm{~cd}$ & $43,0 \mathrm{abc}$ \\
\hline Silicato de cálcio 1 & 243,4 a & $43,8 \mathrm{c}$ & 293,7 a & $362,6 \mathrm{ab}$ & $40,1 \mathrm{~d}$ & $35,7 \mathrm{bc}$ \\
\hline Silicato de cálcio 2 & $240,7 \mathrm{a}$ & $41,9 \mathrm{c}$ & $296,5 \mathrm{a}$ & $298,6 \mathrm{bc}$ & $39,1 \mathrm{~d}$ & $31,2 \mathrm{c}$ \\
\hline Silicato de cálcio e magnésio 1 & $227,6 \mathrm{a}$ & $57,5 \mathrm{ab}$ & $248,7 \mathrm{ab}$ & $371,0 \mathrm{ab}$ & $93,6 \mathrm{a}$ & $46,9 \mathrm{ab}$ \\
\hline Silicato de cálcio e magnésio 2 & 280,0 a & $65,5 \mathrm{a}$ & $275,1 \mathrm{ab}$ & $329,3 \mathrm{ab}$ & $88,4 \mathrm{a}$ & $44,2 \mathrm{abc}$ \\
\hline Wollastonita 1 & $211,0 \mathrm{a}$ & $43,6 \mathrm{c}$ & $213,8 \mathrm{~b}$ & $320,2 \mathrm{abc}$ & $41,2 \mathrm{~d}$ & $36,5 \mathrm{bc}$ \\
\hline Calcário dolomítico 1 & 194,7 a & $47,1 \mathrm{bc}$ & $245,5 \mathrm{ab}$ & $232,3 \mathrm{c}$ & $81,3 \mathrm{ab}$ & $37,9 \mathrm{bc}$ \\
\hline $\mathrm{CV}(\%)$ & 16,6 & 8,9 & 11,3 & 12,2 & 14,9 & 14,2 \\
\hline Tratamentos & $\mathrm{Cu}$ & $\mathrm{Fe}$ & $\mathrm{Mn}$ & $\mathrm{Zn}$ & \multicolumn{2}{|c|}{$\mathrm{B}$} \\
\hline & \multicolumn{4}{|c|}{ |-------------------------- } & \multirow{2}{*}{\multicolumn{2}{|c|}{$1,78 \mathrm{a}$}} \\
\hline Escória 1 & $0,19 \mathrm{a}$ & $5,86 \mathrm{a}$ & $4,41 \mathrm{a}$ & $1,24 \mathrm{ab}$ & & \\
\hline Escória 2 & $0,14 \mathrm{ab}$ & $4,39 \mathrm{a}$ & $3,80 \mathrm{~b}$ & $1,41 \mathrm{a}$ & \multicolumn{2}{|c|}{$1,60 \mathrm{abc}$} \\
\hline Silicato de cálcio 1 & $0,15 \mathrm{ab}$ & $5,50 \mathrm{a}$ & $2,78 \mathrm{c}$ & $1,41 \mathrm{a}$ & \multicolumn{2}{|c|}{$1,53 \mathrm{abcd}$} \\
\hline Silicato de cálcio 2 & $0,13 \mathrm{~b}$ & $5,22 \mathrm{a}$ & $3,05 \mathrm{c}$ & $1,23 \mathrm{ab}$ & \multicolumn{2}{|c|}{$1,45 \mathrm{bcd}$} \\
\hline Silicato de cálcio e magnésio 1 & $0,17 \mathrm{ab}$ & $4,24 \mathrm{a}$ & $3,00 \mathrm{c}$ & $1,05 \mathrm{bc}$ & \multicolumn{2}{|c|}{$1,71 \mathrm{ab}$} \\
\hline Silicato de cálcio e magnésio 2 & $0,16 \mathrm{ab}$ & $4,73 \mathrm{a}$ & $2,83 \mathrm{c}$ & $1,43 \mathrm{a}$ & \multicolumn{2}{|c|}{$1,56 \mathrm{abcd}$} \\
\hline Wollastonita 1 & $0,13 \mathrm{~b}$ & $5,20 \mathrm{a}$ & $1,82 \mathrm{~d}$ & $0,83 \mathrm{c}$ & \multicolumn{2}{|c|}{$1,26 \mathrm{~d}$} \\
\hline Calcário dolomítico 1 & $0,13 \mathrm{~b}$ & $4,78 \mathrm{a}$ & $1,48 \mathrm{~d}$ & $0,73 \mathrm{c}$ & \multicolumn{2}{|c|}{$1,34 \mathrm{~cd}$} \\
\hline $\mathrm{CV}(\%)$ & 15,8 & 22,3 & 8,5 & 11,9 & \multicolumn{2}{|c|}{8,9} \\
\hline
\end{tabular}

\subsubsection{Nitossolo Vermelho eutrófico (NVe)}

\subsubsection{Atributos químicos do solo}

Os tratamentos influenciaram significativamente os atributos químicos deste solo, antes do cultivo da alfafa, exceto para o fósforo, potássio (Tabela 31) e os micronutrientes boro e cobre (Tabela 32).

Assim como ocorreu para o LVd os valores de $\mathrm{pH}$ deste solo foram maiores com a aplicação da escória 1, silicato de cálcio e magnésio 1, seguidos da wollastonita e calcário dolomítico que foram significativamente iguais e refletiram de forma direta na 
menor acidez potencial. Para o silicato de cálcio tanto a dose 1 como a 2 não corrigiram a acidez do solo mantendo o $\mathrm{pH} 4,5$.

O resultado obtido para teores de cálcio, magnésio e valor de soma de bases foi semelhante ao verificado para o LVd. O teor de cálcio foi maior com a aplicação da wollastonita seguido da escória 1 e silicato de cálcio e magnésio 1 os quais não diferiram entre si. A aplicação da escória 2 e silicato de cálcio e magnésio 2 (dose PRNT experimento) também teve bons resultados na disponibilidade de cálcio no solo e proporcionou teores superiores ao obtido com a aplicação do calcário. Para o magnésio os maiores teores foram obtidos com a aplicação do calcário dolomítico, seguido do silicato de cálcio e magnésio (Tabela 31).

Tabela 31 - Resultados das análises químicos do Nitossolo Vermelho eutrófico (NVe) em função dos tratamentos após 30 dias de incubação.

\begin{tabular}{|c|c|c|c|c|c|c|c|c|c|}
\hline Tratamentos & $\mathrm{pH}$ & $\mathrm{P}$ & $\mathrm{H}+\mathrm{Al}$ & $\mathrm{K}$ & $\mathrm{Ca}$ & $\mathrm{Mg}$ & SB & CTC & $\mathrm{V}$ \\
\hline & $\mathrm{CaCl}_{2}$ & $\mathrm{mg} \mathrm{dm}^{-3}$ & -- & ---------- & $--\mathrm{mmol}_{\mathrm{c}}$ & $n^{-3}--$ & ------ & & $\%$ \\
\hline Escória 1 & $6,0 \mathrm{a}$ & $70 \mathrm{a}$ & $28 \mathrm{c}$ & $3,3 \mathrm{a}$ & $49 \mathrm{ab}$ & $10 \mathrm{bc}$ & $62 \mathrm{a}$ & $91 \mathrm{ab}$ & $69 \mathrm{a}$ \\
\hline Escória 2 & $5,3 \mathrm{c}$ & $64 \mathrm{a}$ & $37 \mathrm{bc}$ & $3,4 \mathrm{a}$ & $38 \mathrm{bc}$ & $9 \mathrm{~cd}$ & $51 \mathrm{a}$ & $87 \mathrm{ab}$ & $58 \mathrm{a}$ \\
\hline Silicato de cálcio 1 & $4,5 \mathrm{~d}$ & $54 \mathrm{a}$ & $56 \mathrm{a}$ & $2,8 \mathrm{a}$ & $13 \mathrm{e}$ & $4 \mathrm{~d}$ & $19 \mathrm{~b}$ & $76 \mathrm{~b}$ & $25 \mathrm{~b}$ \\
\hline Silicato de cálcio 2 & $4,5 \mathrm{~d}$ & $61 \mathrm{a}$ & $51 \mathrm{ab}$ & $2,8 \mathrm{a}$ & $18 \mathrm{de}$ & $5 \mathrm{~d}$ & $25 \mathrm{~b}$ & $76 \mathrm{~b}$ & $33 \mathrm{~b}$ \\
\hline Silicato de cálcio e magnésio 1 & $5,9 \mathrm{ab}$ & $62 \mathrm{a}$ & $25 \mathrm{c}$ & $3,0 \mathrm{a}$ & $44 \mathrm{abc}$ & $16 \mathrm{ab}$ & $63 \mathrm{a}$ & $88 \mathrm{ab}$ & $72 \mathrm{a}$ \\
\hline Silicato de cálcio e magnésio 2 & $5,4 \mathrm{bc}$ & $60 \mathrm{a}$ & $35 \mathrm{c}$ & $3,8 \mathrm{a}$ & $33 \mathrm{c}$ & $12 \mathrm{bc}$ & $48 \mathrm{a}$ & $82 a b$ & $58 \mathrm{a}$ \\
\hline Wollastonita 1 & $5,8 \mathrm{abc}$ & $79 \mathrm{a}$ & $26 \mathrm{c}$ & $3,6 \mathrm{a}$ & $54 \mathrm{a}$ & $9 \mathrm{~cd}$ & $67 \mathrm{a}$ & $92 \mathrm{a}$ & $72 \mathrm{a}$ \\
\hline Calcário dolomítico 1 & $5,7 \mathrm{abc}$ & $62 \mathrm{a}$ & $30 \mathrm{c}$ & $3,4 \mathrm{a}$ & $31 \mathrm{~cd}$ & $20 \mathrm{a}$ & $55 \mathrm{a}$ & $85 \mathrm{ab}$ & $63 \mathrm{a}$ \\
\hline $\mathrm{CV}(\%)$ & 4,7 & 18,2 & 17,8 & 22,4 & 17,9 & 22,6 & 17,7 & 7,6 & 14,8 \\
\hline
\end{tabular}

Os valores da CTC do solo foram próximos, com diferença apenas entre o silicato de cálcio e a wollastonita (Tabela 31).

A saturação por bases desejada, $80 \%$, não foi alcançada pelos tratamentos. Os valores mais próximos foram obtidos com a aplicação do silicato de cálcio e magnésio 1 e da wollastonita (72\%). Comparando-se os tratamentos teve-se diferença apenas para o silicato de cálcio, que foi inferior aos demais corretivos (Tabela 31).

Para os micronutrientes os tratamentos diferiram apenas nos teores de ferro, manganês e zinco (Tabela 32). O maior teor de ferro ocorreu com a aplicação da escória 1, seguido do silicato de cálcio 2 e 1 e escória 1 , como já mencionado baixos valores de $\mathrm{pH}$ 
favorecem maior solubilização do ferro, no entanto percebe-se que para a escória o valor de $\mathrm{pH}$ foi o mais alto e ela teve o maior teor de ferro, possivelmente isto ocorreu devido sua composição química. Além de ferro a escória contém manganês, e para este solo se repetiu a superioridade deste material em disponibilizar grande quantidade de manganês.

Os tratamentos com aplicação do silicato de cálcio 1 e 2 e escória 2 proporcionaram o maior teor de zinco. Percebe-se que a escória, assim como o s silicatos podem trazer outros benefícios á fertilidade do solo, não apenas pela influência na correção da acidez do solo, mas por conter em sua constituição química alguns micronutrientes (PRADO et al., 2001).

Tabela 32 - Resultados das análises de micronutrientes do Nitossolo Vermelho eutrófico (NVe) em função dos tratamentos após 30 dias de incubação.

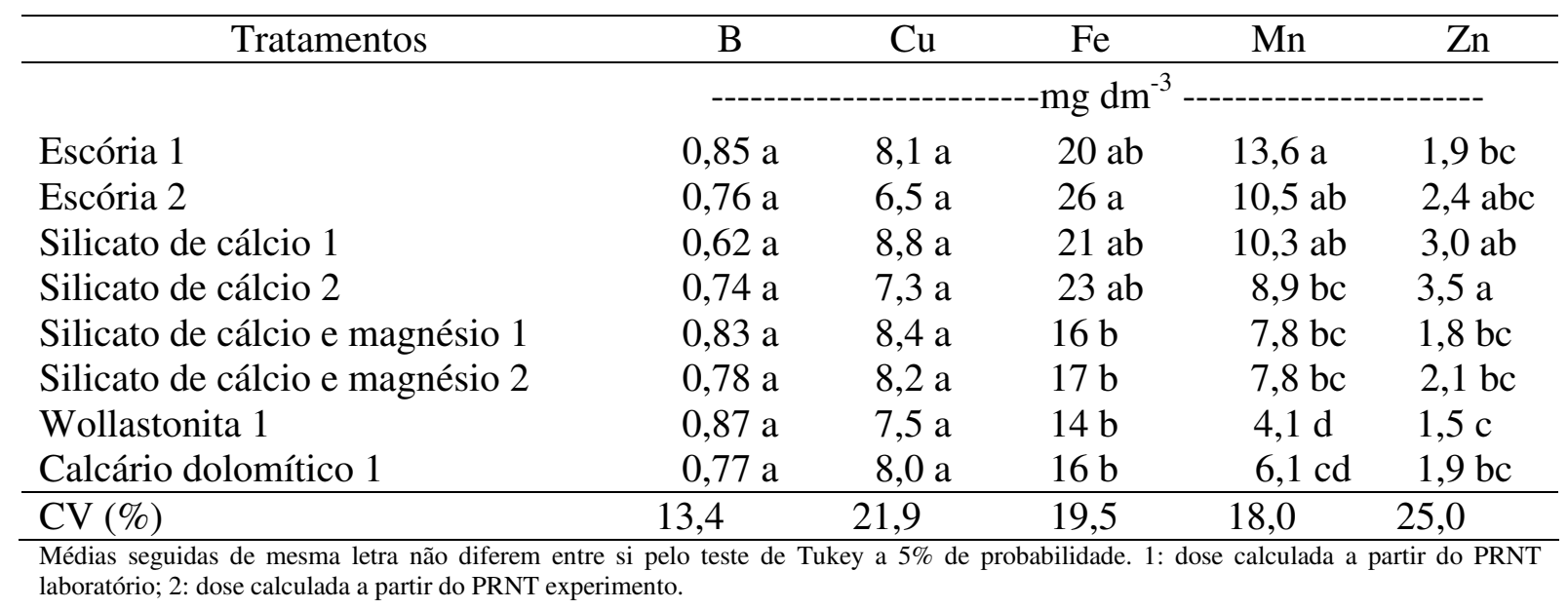

$\mathrm{Na}$ segunda amostragem os tratamentos diferiram significativamente nos atributos químicos: $\mathrm{pH}, \mathrm{H}+\mathrm{Al}, \mathrm{Ca}, \mathrm{Mg}, \mathrm{SB}, \mathrm{CTC}$ e V\% (Tabela 33). Ocorreu diminuição nestes atributos em relação à primeira amostragem, mas os corretivos de maneira geral tiveram o mesmo comportamento nas duas amostragens.

Analisando as Tabelas 31 e 33, verifica-se que o teor de cálcio no solo foi elevado, sendo que no primeiro corte destacou-se a aplicação da wollastonita a qual não diferiu da escória 1 e do silicato de cálcio e magnésio 1 . No segundo corte o maior teor de cálcio passou a ser com a aplicação da escória e silicato de cálcio e magnésio 1, neste corte o teor de cálcio continua elevado mas reduziu em relação à análise de 30 dias de incubação dos 
tratamentos. Em ambas as amostragens, os silicatos, exceto o silicato de cálcio proporcionaram maior teor de cálcio do que o calcário dolomítico.

$\mathrm{Na}$ primeira amostragem a dose calculada com base no PRNT experimento ou no PRNT laboratório, quando analisado para um mesmo corretivo não diferiu no teor de cálcio, magnésio, no valor de soma de bases e saturação por bases do solo, porém na segunda amostragem o teor de cálcio com a aplicação da escória e do silicato de cálcio e magnésio foi significativamente maior quando calculado pelo PRNT laboratório.

$\mathrm{Na}$ segunda amostragem o maior valor da saturação por bases foi alcançado com a aplicação do silicato de cálcio e magnésio 1 (65\%) e nesta amostragem a escória com V\% de 60 foi superior a wollastonita $(\mathrm{V} \%=40)$, mudando assim o resultado obtido para esta variável na primeira amostragem (Tabela 33).

Tabela 33 - Resultados das análises química do Nitossolo Vermelho eutrófico (NVe) em função dos tratamentos após o cultivo da alfafa, 90 dias após incubação.

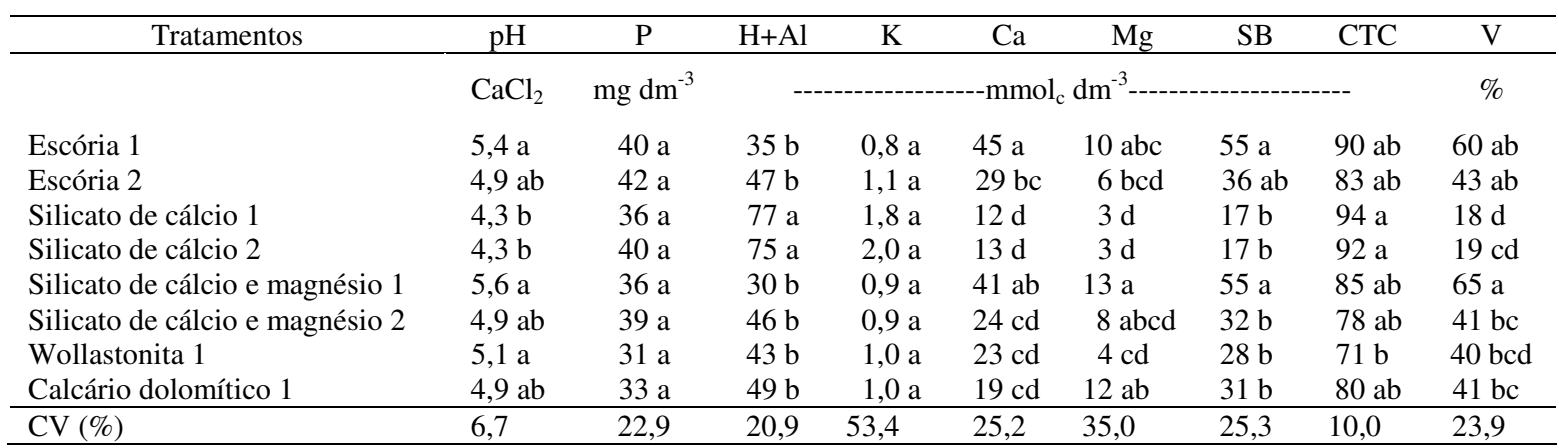

Médias seguidas de mesma letra não diferem entre si pelo teste de Tukey a 5\% de probabilidade. 1: dose calculada a partir do PRNT laboratório; 2: dose calculada a partir do PRNT experimento.

Assim como observado na primeira amostragem o teor de magnésio foi superior com a aplicação do calcário dolomítico e do silicato de cálcio e magnésio 1, no entanto, na segunda amostragem a escória 1 manteve o teor obtido na primeira amostragem de $10 \mathrm{mmol}_{\mathrm{c}} \mathrm{dm}^{-3}$, e foi superior ao ao silicato de cálcio e magnésio $2\left(8 \mathrm{mmol}_{\mathrm{c}} \mathrm{dm}^{-3}\right)$ (Tabela 33$)$.

Neste solo o silicato de cálcio novamente não foi eficiente na correção da acidez do solo, e na disponibilidade de cálcio e magnésio. Os corretivos também não atingiram níveis desejados de correção da acidez do solo, baseado na elevação da saturação por bases a $80 \%$. 
Diferentemente do observado para o LVd ao comparar as duas formas de cálculo nos componentes da acidez, não se obteve diferença entre elas, exceto para a escória no valor de $\mathrm{pH}$ na primeira amostragem, em que a dose baseada no PRNT laboratório foi bem superior e diferiu da dose calculada com o PRNT experimento.

\subsubsection{Variáveis da planta}

Houve diferença significativa entre os tratamentos na produção de matéria seca da parte aérea da alfafa, apenas no primeiro corte (Tabela 34).

Tabela 34 - Matéria seca de parte aérea da alfafa, no primeiro corte (C1) e no segundo corte (C2) em função dos tratamentos no Nitossolo Vermelho eutrófico (NVe).

\begin{tabular}{lcc}
\hline \multirow{2}{*}{ Tratamentos } & \multicolumn{2}{c}{ Matéria Seca (g por vaso) } \\
\cline { 2 - 3 } & $\mathrm{C} 1$ & $\mathrm{C} 2$ \\
\hline Escória 1 & $26,90 \mathrm{a}$ & $17,09 \mathrm{a}$ \\
Escória 2 & $22,40 \mathrm{ab}$ & $15,48 \mathrm{a}$ \\
Silicato de cálcio 1 & $8,73 \mathrm{bc}$ & $19,84 \mathrm{a}$ \\
Silicato de cálcio 2 & $4,45 \mathrm{c}$ & $18,52 \mathrm{a}$ \\
Silicato de cálcio e magnésio 1 & $25,25 \mathrm{a}$ & $20,39 \mathrm{a}$ \\
Silicato de cálcio e magnésio 2 & $27,00 \mathrm{a}$ & $17,36 \mathrm{a}$ \\
Wollastonita 1 & $24,10 \mathrm{a}$ & $19,51 \mathrm{a}$ \\
Calcário dolomítico 1 & $21,93 \mathrm{ab}$ & $18,91 \mathrm{a}$ \\
\hline CV (\%) & 30,2 & 22,6 \\
\hline Médias seguidas de mesma letra não diferem entre si pelo teste de Tukey a 5\% de probabilidade. 1: dose calculada a partir do PRNT \\
laboratório; 2: dose calculada a partir do PRNT experimento.
\end{tabular}

Neste solo teve-se comportamento distinto dos tratamentos entre os cortes, no primeiro corte o silicato de cálcio e magnésio 1 e 2, a escória 1 e a wollastonita proporcionaram as maiores produções de matéria seca, diferindo apenas do silicato de cálcio que ficou bem distante dos demais tratamentos. No entanto, no segundo corte os resultados se alteraram bastante, e verifica-se que o único corretivo que teve aumento na produção de matéria seca em relação ao primeiro corte foi o silicato de cálcio, o qual neste corte destacouse pela maior produção de matéria seca e foi inferior apenas ao silicato de cálcio e magnésio.

Os teores médios de nutrientes na parte aérea da alfafa estão contidos nas Tabelas 35 e 36 . Verifica-se que ocorreu diferença significativa entre os tratamentos nos 
teores de N, P, K, Mg, Fe e Mn, no primeiro corte (Tabela 35), e nos teores de N, P, K, Ca, $\mathrm{Mg}, \mathrm{Mn}$ e B no segundo corte (Tabela 36).

Tabela 35 - Teores médios de nutrientes na parte aérea de plantas de alfafa ( $1^{\circ}$ corte) em função dos tratamentos aplicados no Nitossolo Vermelho eutrófico (NVe).

\begin{tabular}{|c|c|c|c|c|c|c|c|c|c|c|c|}
\hline Tratamentos & $\mathrm{N}$ & $\mathrm{P}$ & $\mathrm{K}$ & $\mathrm{Ca}$ & $\mathrm{Mg}$ & $\mathrm{S}$ & $\mathrm{Cu}$ & $\mathrm{Fe}$ & $\mathrm{Mn}$ & $\mathrm{Zn}$ & B \\
\hline & \multicolumn{6}{|c|}{-----------------------------g kg } & \multicolumn{5}{|c|}{--------------------'mg kg } \\
\hline Escória 1 & $32 \mathrm{c}$ & $2,9 \mathrm{ab}$ & $25 \mathrm{ab}$ & $20 \mathrm{a}$ & $2,8 \mathrm{c}$ & $2,3 \mathrm{a}$ & $8 \mathrm{a}$ & $93 \mathrm{~b}$ & $270 \mathrm{bc}$ & $35 \mathrm{a}$ & $62 \mathrm{a}$ \\
\hline Escória 2 & $33 \mathrm{bc}$ & $2,8 \mathrm{~b}$ & $27 \mathrm{ab}$ & $19 \mathrm{a}$ & $2,8 \mathrm{c}$ & $2,3 \mathrm{a}$ & $8 \mathrm{a}$ & $105 \mathrm{ab}$ & $418 \mathrm{ab}$ & $40 \mathrm{a}$ & $64 \mathrm{a}$ \\
\hline Silicato de cálcio 1 & $46 \mathrm{a}$ & $4,1 \mathrm{a}$ & $32 a b$ & $20 \mathrm{a}$ & $2,7 \mathrm{c}$ & $2,5 \mathrm{a}$ & $9 \mathrm{a}$ & $124 \mathrm{ab}$ & 563 a & $61 \mathrm{a}$ & $67 \mathrm{a}$ \\
\hline Silicato de cálcio 2 & $44 \mathrm{ab}$ & $2,6 b$ & 35 a & $15 \mathrm{a}$ & $2,7 \mathrm{c}$ & $2,3 \mathrm{a}$ & $10 \mathrm{a}$ & $192 \mathrm{a}$ & 549 a & $55 \mathrm{a}$ & $73 \mathrm{a}$ \\
\hline Silicato de cálio e magnésio 1 & $34 \mathrm{bc}$ & $3,0 \mathrm{ab}$ & $23 \mathrm{~b}$ & $18 \mathrm{a}$ & $3,4 \mathrm{~b}$ & $2,3 \mathrm{a}$ & $9 \mathrm{a}$ & $109 \mathrm{ab}$ & $162 \mathrm{~d}$ & $34 \mathrm{a}$ & $66 \mathrm{a}$ \\
\hline Silicato de cálcio e magnésio 2 & $33 \mathrm{bc}$ & $3,1 \mathrm{ab}$ & $24 \mathrm{~b}$ & $17 \mathrm{a}$ & $3,4 \mathrm{~b}$ & $2,4 \mathrm{a}$ & $6 \mathrm{a}$ & $101 \mathrm{ab}$ & $283 \mathrm{bc}$ & $48 \mathrm{a}$ & $62 \mathrm{a}$ \\
\hline Wollastonita 1 & $34 \mathrm{bc}$ & $3,4 \mathrm{ab}$ & $24 \mathrm{~b}$ & $19 \mathrm{a}$ & $2,6 \mathrm{c}$ & $2,3 \mathrm{a}$ & $8 \mathrm{a}$ & $104 \mathrm{ab}$ & $212 b c$ & $56 \mathrm{a}$ & $64 \mathrm{a}$ \\
\hline Calcário dolomítico 1 & 38 abc & $3,2 \mathrm{ab}$ & $27 \mathrm{ab}$ & $16 \mathrm{a}$ & $4,6 \mathrm{a}$ & $2,4 \mathrm{a}$ & $8 \mathrm{a}$ & $104 \mathrm{ab}$ & $165 \mathrm{~d}$ & $40 \mathrm{a}$ & $66 \mathrm{a}$ \\
\hline $\mathrm{CV}(\%)$ & 13,4 & 16,7 & 16,3 & 14,8 & 6,6 & 10,2 & 19,9 & 35,4 & 26,9 & 42,1 & 12,0 \\
\hline
\end{tabular}

Médias seguidas de mesma letra não diferem entre si pelo teste de Tukey a 5\% de probabilidade. 1: dose calculada a partir do PRNT laboratório; 2: dose calculada a partir do PRNT experimento.

Tabela 36 - Teores médios de nutrientes na parte aérea de plantas de alfafa ( $2^{\circ}$ corte) em função dos tratamentos aplicados no Nitossolo Vermelho eutrófico (NVe).

\begin{tabular}{|c|c|c|c|c|c|c|c|c|c|c|c|}
\hline Tratamentos & $\mathrm{N}$ & $\mathrm{P}$ & $\mathrm{K}$ & $\mathrm{Ca}$ & $\mathrm{Mg}$ & $\mathrm{S}$ & $\mathrm{Cu}$ & $\mathrm{Fe}$ & $\mathrm{Mn}$ & $\mathrm{Zn}$ & B \\
\hline & \multicolumn{6}{|c|}{ 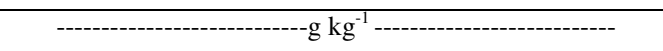 } & \multicolumn{5}{|c|}{ 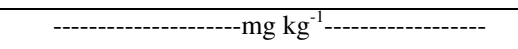 } \\
\hline Escória 1 & $20 \mathrm{ab}$ & $3,6 \mathrm{a}$ & $16 a b$ & $26 \mathrm{a}$ & $3,5 \mathrm{bc}$ & $3,0 \mathrm{a}$ & $13 \mathrm{a}$ & $550 \mathrm{a}$ & $324 \mathrm{bc}$ & $59 \mathrm{a}$ & $104 \mathrm{ab}$ \\
\hline Escória 2 & $17 \mathrm{ab}$ & $3,3 \mathrm{ab}$ & $18 \mathrm{ab}$ & $24 \mathrm{ab}$ & $3,2 \mathrm{bc}$ & $2,7 \mathrm{a}$ & $11 \mathrm{a}$ & $447 \mathrm{a}$ & $445 \mathrm{ab}$ & $71 \mathrm{a}$ & $106 \mathrm{a}$ \\
\hline Silicato de cálcio 1 & $28 \mathrm{ab}$ & $3,2 \mathrm{ab}$ & $23 a b$ & $21 \mathrm{abc}$ & $3,0 \mathrm{c}$ & $2,4 \mathrm{a}$ & $10 \mathrm{a}$ & $327 \mathrm{a}$ & $454 \mathrm{ab}$ & $54 \mathrm{a}$ & $73 \mathrm{bc}$ \\
\hline Silicato de cálcio 2 & $32 \mathrm{a}$ & $2,7 \mathrm{~b}$ & $25 \mathrm{a}$ & $16 \mathrm{c}$ & $2,7 \mathrm{c}$ & $2,4 \mathrm{a}$ & $10 \mathrm{a}$ & $381 \mathrm{a}$ & $461 \mathrm{a}$ & $56 \mathrm{a}$ & $70 \mathrm{c}$ \\
\hline Silicato de cálio e magnésio 1 & $16 \mathrm{~b}$ & $3,5 \mathrm{ab}$ & $15 \mathrm{~b}$ & $23 \mathrm{abc}$ & $4,4 \mathrm{ab}$ & $2,9 \mathrm{a}$ & $13 \mathrm{a}$ & $395 \mathrm{a}$ & $229 \mathrm{~cd}$ & $55 \mathrm{a}$ & $97 \mathrm{abc}$ \\
\hline Silicato de cálcio e magnésio 2 & $20 \mathrm{ab}$ & $3,8 \mathrm{a}$ & $18 \mathrm{ab}$ & $25 \mathrm{ab}$ & $5,0 \mathrm{a}$ & $2,9 \mathrm{a}$ & $13 \mathrm{a}$ & $464 \mathrm{a}$ & $345 \mathrm{abc}$ & $79 \mathrm{a}$ & $102 \mathrm{ab}$ \\
\hline Wollastonita 1 & $17 \mathrm{ab}$ & $3,4 \mathrm{ab}$ & $16 a b$ & $26 \mathrm{ab}$ & $3,1 \mathrm{c}$ & $2,4 \mathrm{a}$ & $12 \mathrm{a}$ & $368 \mathrm{a}$ & $162 \mathrm{~d}$ & $48 \mathrm{a}$ & $85 \mathrm{abc}$ \\
\hline Calcário dolomítico 1 & $24 \mathrm{ab}$ & $3,5 \mathrm{ab}$ & $17 a b$ & $18 \mathrm{bc}$ & $4,8 \mathrm{a}$ & $2,7 \mathrm{a}$ & $13 \mathrm{a}$ & $394 \mathrm{a}$ & $219 \mathrm{~cd}$ & $57 \mathrm{a}$ & $93 \mathrm{abc}$ \\
\hline $\mathrm{CV}(\%)$ & 30,1 & 10,5 & 22,0 & 14,8 & 14,4 & 18,1 & 15,7 & 24,9 & 17,4 & 22,6 & 14,2 \\
\hline
\end{tabular}

Médias seguidas de mesma letra não diferem entre si pelo teste de Tukey a 5\% de probabilidade. 1: dose calculada a partir do PRNT laboratório; 2: dose calculada a partir do PRNT experimento.

O maior teor de nitrogênio, fósforo e potássio foram obtidos com a aplicação do silicato de cálcio (Tabelas 35 e 36). No primeiro corte os teores destes nutrientes encontravam-se na faixa adequada para a alfafa (RAIJ et al.,1996). No segundo corte o teor de $\mathrm{N}$ e K reduziu e ficou abaixo da faixa adequada. Nos teores de N, P e K os demais tratamentos não apresentaram diferenças significativas entre si nos dois cortes avaliados. 
Novamente a aplicação do calcário dolomítico e do silicato de cálcio e magnésio proporcionaram o maior teor de magnésio na parte aérea da alfafa, os demais tratamentos não diferiram entre si.

Dentre os micronutrientes apenas o manganês e o ferro $\left(1^{\circ}\right.$ corte $), o$ manganês e o boro $\left(2^{\circ}\right.$ corte) foram influenciados significativamente pelos tratamentos, com valores elevados, principalmente quando aplicado o silicato de cálcio, exceto para o boro que teve o maior teor com a aplicação da escória.

As doses 1 e 2 (PRNT laboratório e PRNT experimento, respectivamente) diferiram entre si apenas no segundo corte. Sendo que o teor de fósforo com a aplicação do silicato de cálcio foi superior com a aplicação da dose 1 e o teor de manganês com aplicação do silicato de cálcio e magnésio 2.

Como também verificado para o $\mathrm{LVd}$, no $\mathrm{NVe}$ o teor de $\mathrm{P}, \mathrm{Ca}, \mathrm{Mg}$, $\mathrm{Cu}, \mathrm{Fe}, \mathrm{Mn}, \mathrm{Zn}$ e B aumentou em relação ao primeiro corte. O aumento no teor destes nutrientes, como já mencionado se deve ao efeito concentração, pois ocorreu diminuição na produção de matéria seca da parte aérea da alfafa e diminuição do acúmulo dos nutrientes.

$\mathrm{O}$ acúmulo médio de nutrientes na parte aérea da alfafa, no primeiro e segundo corte está nas Tabelas 37 e 38, respectivamente.

No primeiro corte o maior acúmulo de $\mathrm{N}$ foi obtido com a aplicação do silicato de cálcio e magnésio 2 que diferiu apenas do silicato de cálcio 1 e 2 . No segundo corte, o silicato de cálcio passou a ter o maior acúmulo de N. Percebe-se que o aumento no acúmulo do primeiro para o segundo corte com a aplicação do silicato de cálcio ocorreu para praticamente todos os nutrientes, e este fato se deve ao aumento na produção de matéria seca no segundo corte em relação ao primeiro.

Para os demais corretivos o acúmulo de nutrientes tendeu a diminuir no segundo corte, tendo apenas o ferro o seu acúmulo elevado no segundo corte. 
Tabela 37 - Acúmulo médio de nutrientes na parte aérea de plantas de alfafa $\left(1^{\circ}\right.$ corte $)$ em função dos tratamentos aplicados no Nitossolo Vermelho eutrófico (NVe).

\begin{tabular}{|c|c|c|c|c|c|c|}
\hline Tratamentos & $\mathrm{N}$ & $\mathrm{P}$ & $\mathrm{K}$ & $\mathrm{Ca}$ & $\mathrm{Mg}$ & $\mathrm{S}$ \\
\hline Escória 1 & $839,1 \mathrm{ab}$ & $76,4 \mathrm{ab}$ & 653,1 a & $531,5 \mathrm{a}$ & $74,9 \mathrm{ab}$ & $61,5 \mathrm{a}$ \\
\hline Escória 2 & $739,1 \mathrm{ab}$ & $60,9 \mathrm{c}$ & $588,1 \mathrm{a}$ & $420,8 \mathrm{ab}$ & $63,1 \mathrm{abc}$ & $50,5 \mathrm{ab}$ \\
\hline Silicato de cálcio 1 & $407,5 \mathrm{bc}$ & $34,4 \mathrm{bc}$ & $272,9 \mathrm{bc}$ & $177,5 \mathrm{bc}$ & $23,8 \mathrm{bc}$ & $22,6 \mathrm{bc}$ \\
\hline Silicato de cálcio 2 & $194,3 \mathrm{c}$ & $11,5 \mathrm{ab}$ & $153,4 \mathrm{c}$ & $65,0 \mathrm{c}$ & $11,8 \mathrm{c}$ & $10,3 \mathrm{c}$ \\
\hline Silicato de cálcio e magnésio 1 & $859,0 \mathrm{ab}$ & $75,8 \mathrm{ab}$ & 588,9 a & $455,9 \mathrm{ab}$ & 86,9 a & $58,9 \mathrm{ab}$ \\
\hline Silicato de cálcio e magnésio 2 & $878,3 \mathrm{a}$ & $82,8 \mathrm{a}$ & $639,7 \mathrm{a}$ & $468,0 \mathrm{a}$ & $92,5 \mathrm{a}$ & $63,0 \mathrm{a}$ \\
\hline Wollastonita 1 & $794,5 \mathrm{ab}$ & $78,8 \mathrm{ab}$ & $582,2 \mathrm{ab}$ & $465,9 \mathrm{ab}$ & $63,1 \mathrm{abc}$ & $54,2 \mathrm{ab}$ \\
\hline Calcário dolomítico 1 & $723,1 \mathrm{ab}$ & $63,8 \mathrm{ab}$ & $496,1 \mathrm{ab}$ & $339,2 \mathrm{abc}$ & $99,7 \mathrm{a}$ & $53,0 \mathrm{ab}$ \\
\hline $\mathrm{CV}(\%)$ & 29,1 & 32,4 & 26,5 & 33,4 & 37,9 & 32,9 \\
\hline Tratamentos & $\mathrm{Cu}$ & $\mathrm{Fe}$ & $\mathrm{Mn}$ & $\mathrm{Zn}$ & \multicolumn{2}{|c|}{ B } \\
\hline Escória 1 & \multicolumn{6}{|c|}{ 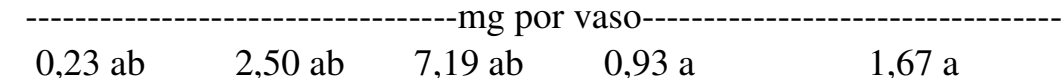 } \\
\hline Escória 2 & $0,18 a b c$ & $2,35 \mathrm{ab}$ & 9,09 a & $0,88 \mathrm{a}$ & \multicolumn{2}{|c|}{$1,42 \mathrm{ab}$} \\
\hline Silicato de cálcio 1 & $0,07 \mathrm{bc}$ & $1,09 \mathrm{ab}$ & $4,60 \mathrm{abc}$ & $0,59 \mathrm{a}$ & \multicolumn{2}{|c|}{$0,57 \mathrm{bc}$} \\
\hline Silicato de cálcio 2 & $0,04 \mathrm{c}$ & $0,84 \mathrm{~b}$ & $2,46 \mathrm{c}$ & $0,25 \mathrm{a}$ & \multicolumn{2}{|c|}{$0,32 \mathrm{c}$} \\
\hline Silicato de cálcio e magnésio 1 & $0,23 \mathrm{a}$ & $2,77 \mathrm{a}$ & $4,11 \mathrm{bc}$ & $0,86 \mathrm{a}$ & \multicolumn{2}{|c|}{$1,68 \mathrm{a}$} \\
\hline Silicato de cálcio e magnésio 2 & $0,16 a b c$ & $2,75 \mathrm{a}$ & $7,57 \mathrm{ab}$ & $1,29 \mathrm{a}$ & \multicolumn{2}{|c|}{$1,67 \mathrm{a}$} \\
\hline Wollastonita 1 & $0,19 a b c$ & $2,54 \mathrm{a}$ & $5,03 \mathrm{abc}$ & $1,33 \mathrm{a}$ & \multicolumn{2}{|c|}{$1,53 \mathrm{a}$} \\
\hline Calcário dolomítico 1 & $0,18 a b c$ & $1,80 \mathrm{ab}$ & $3,70 \mathrm{bc}$ & $0,87 \mathrm{a}$ & \multicolumn{2}{|c|}{$1,37 \mathrm{ab}$} \\
\hline $\mathrm{CV}(\%)$ & 41,0 & 34,3 & 36,2 & 56,9 & \multicolumn{2}{|l|}{29,0} \\
\hline
\end{tabular}


Tabela 38 - Acúmulo médio de nutrientes na parte aérea de plantas de alfafa $\left(2^{\circ}\right.$ corte $)$ em função dos tratamentos aplicados no Nitossolo Vermelho eutrófico (NVe).

\begin{tabular}{|c|c|c|c|c|c|c|}
\hline Tratamentos & $\mathrm{N}$ & $\mathrm{P}$ & K & $\mathrm{Ca}$ & $\mathrm{Mg}$ & $S$ \\
\hline & & & $---m g$ p & r vaso ----- & & \\
\hline Escória 1 & $336,6 \mathrm{~b}$ & $60,1 \mathrm{a}$ & 265,4 a & 445,0 a & $60,2 \mathrm{ab}$ & 50,4 a \\
\hline Escória 2 & $259,4 \mathrm{ab}$ & $50,6 \mathrm{a}$ & $267,8 \mathrm{a}$ & $369,5 \mathrm{a}$ & $48,8 \mathrm{~b}$ & $40,1 \mathrm{a}$ \\
\hline Silicato de cálcio 1 & $472,2 \mathrm{ab}$ & $61,3 \mathrm{a}$ & $429,1 \mathrm{a}$ & $422,4 \mathrm{a}$ & $58,0 \mathrm{ab}$ & $45,8 \mathrm{a}$ \\
\hline Silicato de cálcio 2 & 572,6 a & $48,2 \mathrm{a}$ & 437,4 a & $283,7 \mathrm{a}$ & $49,1 \mathrm{~b}$ & $43,2 \mathrm{a}$ \\
\hline Silicato de cálcio e magnésio 1 & $326,2 \mathrm{ab}$ & $71,4 \mathrm{a}$ & 306,1 a & $473,0 \mathrm{a}$ & $89,3 \mathrm{a}$ & $59,0 \mathrm{a}$ \\
\hline Silicato de cálcio e magnésio 2 & $343,4 \mathrm{ab}$ & $64,5 \mathrm{a}$ & 307,5 a & $423,0 \mathrm{a}$ & $85,7 \mathrm{a}$ & $49,2 \mathrm{a}$ \\
\hline Wollastonita 1 & $327,0 \mathrm{ab}$ & $65,2 \mathrm{a}$ & $309,1 \mathrm{a}$ & 493,7 a & $59,5 \mathrm{ab}$ & $45,9 \mathrm{a}$ \\
\hline Calcário dolomítico 1 & $461,7 \mathrm{ab}$ & $65,7 \mathrm{a}$ & $319,5 \mathrm{a}$ & $331,5 \mathrm{a}$ & $88,5 \mathrm{a}$ & $49,6 \mathrm{a}$ \\
\hline $\mathrm{CV}(\%)$ & 31,8 & 20,4 & 26,0 & 23,4 & 20,3 & 17,9 \\
\hline Tratamentos & $\mathrm{Cu}$ & $\mathrm{Fe}$ & $\mathrm{Mn}$ & $\mathrm{Zn}$ & \multicolumn{2}{|c|}{$\mathrm{B}$} \\
\hline & \multicolumn{6}{|c|}{--------------------------------mg por vaso ------------------------ } \\
\hline Escória 1 & $0,22 \mathrm{a}$ & $9,47 \mathrm{a}$ & $5,55 \mathrm{ab}$ & 0,99 a & \multicolumn{2}{|c|}{$1,78 \mathrm{a}$} \\
\hline Escória 2 & $0,17 \mathrm{a}$ & $6,62 \mathrm{a}$ & $6,76 a b$ & $1,07 \mathrm{a}$ & \multicolumn{2}{|c|}{$1,67 \mathrm{a}$} \\
\hline Silicato de cálcio 1 & $0,20 \mathrm{a}$ & $5,93 \mathrm{a}$ & $8,53 \mathrm{a}$ & $1,09 \mathrm{a}$ & \multicolumn{2}{|c|}{$1,49 \mathrm{a}$} \\
\hline Silicato de cálcio 2 & $0,18 \mathrm{a}$ & $7,28 \mathrm{a}$ & $8,53 \mathrm{a}$ & 0,97 a & \multicolumn{2}{|c|}{$1,32 \mathrm{a}$} \\
\hline Silicato de cálcio e magnésio 1 & $0,27 \mathrm{a}$ & $8,03 \mathrm{a}$ & $4,68 \mathrm{ab}$ & $1,13 \mathrm{a}$ & \multicolumn{2}{|c|}{$1,97 \mathrm{a}$} \\
\hline Silicato de cálcio e magnésio 2 & $0,22 \mathrm{a}$ & $7,91 \mathrm{a}$ & $5,82 \mathrm{ab}$ & $1,33 \mathrm{a}$ & \multicolumn{2}{|c|}{$1,73 \mathrm{a}$} \\
\hline Wollastonita 1 & $0,23 \mathrm{a}$ & $6,91 \mathrm{a}$ & $3,08 \mathrm{~b}$ & $0,90 \mathrm{a}$ & \multicolumn{2}{|c|}{$1,63 \mathrm{a}$} \\
\hline Calcário dolomítico 1 & $0,24 \mathrm{a}$ & $7,51 \mathrm{a}$ & $4,02 \mathrm{~b}$ & $1,05 \mathrm{a}$ & \multicolumn{2}{|c|}{$1,72 \mathrm{a}$} \\
\hline $\mathrm{CV}(\%)$ & 21,8 & 29,5 & 29,0 & 26,3 & \multicolumn{2}{|c|}{21,6} \\
\hline
\end{tabular}

Médias seguidas de mesma letra não diferem entre si pelo teste de Tukey a 5\% de probabilidade. 1: dose calculada a partir do PRNT laboratório; 2: dose calculada a partir do PRNT experimento.

\subsubsection{Neossolo Quartzarênico (NQ)}

\subsubsection{Atributos químicos do solo}

Os tratamentos diferiram significativamente no teor de $\mathrm{Ca}, \mathrm{Mg}$, nos valores de SB e V\% (Tabela 39) e no teor de Mn (Tabela 40). Neste solo verifica-se menor efeito dos tratamentos sobre os atributos químicos.

$\mathrm{O} \mathrm{pH}$ do solo ficou em torno de 5,0, e a acidez potencial acompanhou os resultados verificados para o $\mathrm{pH}$ e também não foi influenciada pelos tratamentos. 
Tabela 39 - Resultados das análises química do Neossolo Quartzarênico (NQ) em função dos tratamentos após 30 dias de incubação.

\begin{tabular}{|c|c|c|c|c|c|c|c|c|c|}
\hline Tratamentos & $\mathrm{pH}$ & $\mathrm{P}$ & $\mathrm{H}+\mathrm{Al}$ & $\mathrm{K}$ & $\mathrm{Ca}$ & $\mathrm{Mg}$ & SB & CTC & $\mathrm{V}$ \\
\hline & $\mathrm{CaCl}_{2}$ & $\mathrm{mg} \mathrm{dm}^{-3}$ & --- & ------ & ------m & $\mathrm{dm}^{-3}$ & & - & $\%$ \\
\hline Escória 1 & $5,0 \mathrm{a}$ & $53 \mathrm{a}$ & $26 \mathrm{a}$ & $3,1 \mathrm{a}$ & $22 \mathrm{a}$ & $7 \mathrm{a}$ & $32 \mathrm{a}$ & $57 \mathrm{a}$ & $55 \mathrm{ab}$ \\
\hline Escória 2 & $4,7 \mathrm{a}$ & $68 \mathrm{a}$ & $33 \mathrm{a}$ & $3,0 \mathrm{a}$ & $14 \mathrm{c}$ & $4 \mathrm{c}$ & $21 \mathrm{~cd}$ & $54 \mathrm{a}$ & $40 \mathrm{c}$ \\
\hline Silicato de cálcio 1 & $4,7 \mathrm{a}$ & $64 \mathrm{a}$ & $25 \mathrm{a}$ & $3,3 \mathrm{a}$ & $14 \mathrm{c}$ & $4 \mathrm{c}$ & $21 \mathrm{~cd}$ & $46 a$ & $46 \mathrm{abc}$ \\
\hline Silicato de cálcio 2 & $4,6 \mathrm{a}$ & $60 \mathrm{a}$ & $27 \mathrm{a}$ & $3,2 \mathrm{a}$ & $13 \mathrm{c}$ & $4 \mathrm{c}$ & $20 \mathrm{~d}$ & $47 \mathrm{a}$ & $43 \mathrm{bc}$ \\
\hline Silicato de cálcio e magnésio 1 & $5,2 \mathrm{a}$ & $57 \mathrm{a}$ & $22 \mathrm{a}$ & $3,1 \mathrm{a}$ & $19 \mathrm{ab}$ & $7 \mathrm{a}$ & $29 \mathrm{ab}$ & $50 \mathrm{a}$ & $57 \mathrm{a}$ \\
\hline Silicato de cálcio e magnésio 2 & 5,0 a & $57 \mathrm{a}$ & $22 \mathrm{a}$ & $2,7 \mathrm{a}$ & $16 \mathrm{bc}$ & $6 \mathrm{abc}$ & $24 \mathrm{bcd}$ & $46 a$ & $52 \mathrm{abc}$ \\
\hline Wollastonita 1 & $5,1 \mathrm{a}$ & $63 a$ & $21 \mathrm{a}$ & $3,4 \mathrm{a}$ & $20 \mathrm{ab}$ & $5 \mathrm{bc}$ & $28 \mathrm{abc}$ & $49 \mathrm{a}$ & $56 \mathrm{ab}$ \\
\hline Calcário dolomítico 1 & $5,0 \mathrm{a}$ & $45 \mathrm{a}$ & $23 \mathrm{a}$ & $2,4 \mathrm{a}$ & $15 \mathrm{bc}$ & $7 \mathrm{a}$ & 25 abcd & $47 \mathrm{a}$ & $52 \mathrm{abc}$ \\
\hline $\mathrm{CV}(\%)$ & 4,6 & 26,6 & 23,4 & 21,2 & 12,5 & 17,4 & 12,4 & 10,2 & 11,8 \\
\hline
\end{tabular}

Médias seguidas de mesma letra não diferem entre si pelo teste de Tukey a 5\% de probabilidade. 1: dose calculada a partir do PRNT laboratório; 2: dose calculada a partir do PRNT experimento.

Os teores de cálcio foram bem mais baixos neste solo do que os encontrados para o LVd e NVe. Verifica-se para este solo que os teores de cálcio estão próximos ou abaixo dos encontrados nas condições iniciais (Tabela 1), porém considerando a análise estatística, percebe-se que o resultado foi igual para os três solos estudados, onde se teve maior teor de cálcio com a aplicação da escória 1, do silicato de cálcio e magnésio 1 e da wollastonita.

A escória, o silicato de cálcio e magnésio e o calcário dolomítico foram os corretivos que promoveram o maior teor de magnésio (Tabela 39), fato observado nos três solos.

O valor de soma de bases também está próximo ao encontrado na condição inicial do solo $\left(27 \mathrm{mmol}_{\mathrm{c}} \mathrm{dm}^{-3}\right)$, para este atributo ocorreu diferença significativa entre os tratamentos, tendo superioridade a escória 1, silicato de cálcio e magnésio 1, wollastonita e calcário dolomítico, os quais não diferiram entre si (Tabela 39).

Os tratamentos influenciaram significativamente o valor de saturação, entretanto, os valores obtidos ficaram distantes do valor desejado de $80 \%$.

Para os micronutrientes os tratamentos influenciaram apenas o teor de manganês (Tabela 40). Neste solo o maior teor deste micronutriente foi observado para o silicato de cálcio e para o calcário dolomítico, os quais não diferiram da escória 1 e silicato de cálcio e magnésio 2, diferenciado-se assim dos dados obtidos para o LVd e o NVe. 
Tabela 40 - Resultados das análises químicas de micronutriente do Neossolo Quartzarênico (NQ) em função dos tratamentos após 30 dias de incubação.

\begin{tabular}{lccccc}
\hline \multicolumn{1}{c}{ Tratamentos } & $\mathrm{B}$ & $\mathrm{Cu}$ & $\mathrm{Fe}$ & $\mathrm{Mn}$ & $\mathrm{Zn}$ \\
\hline & ------------------- & $\mathrm{mg} \mathrm{dm}$ & \\
& $0,69 \mathrm{a}$ & $2,2 \mathrm{a}$ & $27 \mathrm{a}$ & $7,0 \mathrm{abc}$ & $2,9 \mathrm{a}$ \\
Escória 1 & $0,59 \mathrm{a}$ & $2,1 \mathrm{a}$ & $36 \mathrm{a}$ & $6,6 \mathrm{bc}$ & $4,4 \mathrm{a}$ \\
Escória 2 & $0,66 \mathrm{a}$ & $2,4 \mathrm{a}$ & $35 \mathrm{a}$ & $12,6 \mathrm{a}$ & $4,7 \mathrm{a}$ \\
Silicato de cálcio 1 & $0,59 \mathrm{a}$ & $2,1 \mathrm{a}$ & $34 \mathrm{a}$ & $10,6 \mathrm{abc}$ & $4,9 \mathrm{a}$ \\
Silicato de cálcio 2 & $0,62 \mathrm{a}$ & $1,8 \mathrm{a}$ & $23 \mathrm{a}$ & $6,6 \mathrm{bc}$ & $2,9 \mathrm{a}$ \\
Silicato de cálcio e magnésio 1 & $0,60 \mathrm{a}$ & $1,9 \mathrm{a}$ & $27 \mathrm{a}$ & $8,7 \mathrm{abc}$ & $3,5 \mathrm{a}$ \\
Silicato de cálcio e magnésio 2 & $0,84 \mathrm{a}$ & $2,4 \mathrm{a}$ & $22 \mathrm{a}$ & $5,2 \mathrm{c}$ & $4,0 \mathrm{a}$ \\
Wollastonita 1 & $0,54 \mathrm{a}$ & $1,8 \mathrm{a}$ & $26 \mathrm{a}$ & $11,9 \mathrm{ab}$ & $2,8 \mathrm{a}$ \\
Calcário dolomítico 1 & 22,5 & 25,6 & 22,9 & 29,2 & 37,4 \\
\hline CV $(\%)$ & & & &
\end{tabular}

Médias seguidas de mesma letra não diferem entre si pelo teste de Tukey a 5\% de probabilidade. 1: dose calculada a partir do PRNT laboratório; 2: dose calculada a partir do PRNT experimento.

Os atributos químicos $\mathrm{pH}, \mathrm{H}+\mathrm{Al}, \mathrm{Ca}, \mathrm{SB}$ e $\mathrm{V} \%$ da segunda amostragem foram influenciados significativamente pelos tratamentos (Tabela 41). Todos os atributos tiveram seu valor reduzido em relação à primeira amostragem, chegando a valores inferiores aos encontrados na condição inicial do solo para pH, Ca, $\mathrm{Mg}, \mathrm{SB}$ e V\%.

Nesta amostragem os teores de magnésio obtidos com a aplicação do calcário dolomítico e do silicato de cálcio e magnésio reduziu bastante em relação à primeira amostragem e desta forma igualou-se aos demais corretivos (Tabela 41).

Tabela 41 - Resultados das análises químicas do Neossolo Qartzarênico (NQ) em função dos tratamentos após o cultivo da alfafa, 90 dias após incubação.

\begin{tabular}{|c|c|c|c|c|c|c|c|c|c|}
\hline Tratamentos & $\mathrm{pH}$ & $\mathrm{P}$ & $\mathrm{H}+\mathrm{Al}$ & $\mathrm{K}$ & $\mathrm{Ca}$ & $\mathrm{Mg}$ & SB & CTC & $\mathrm{V}$ \\
\hline & $\mathrm{CaCl}_{2}$ & $\mathrm{mg} \mathrm{dm}^{-3}$ & & ---- & $\mathrm{mmol}_{\mathrm{c}} \mathrm{d}$ & -3 & - & 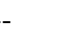 & $\%$ \\
\hline Escória 1 & $4,4 \mathrm{ab}$ & $41 \mathrm{a}$ & $31 \mathrm{ab}$ & $1,3 \mathrm{a}$ & $16 \mathrm{a}$ & $5 \mathrm{a}$ & $22 \mathrm{a}$ & $51 \mathrm{a}$ & $41 \mathrm{ab}$ \\
\hline Escória 2 & $4,2 \mathrm{~b}$ & $42 \mathrm{a}$ & $34 \mathrm{ab}$ & $1,1 \mathrm{a}$ & $13 \mathrm{abc}$ & $4 \mathrm{a}$ & $17 \mathrm{ab}$ & 53 a & $33 \mathrm{abc}$ \\
\hline Silicato de cálcio 1 & $4,2 \mathrm{~b}$ & $40 \mathrm{a}$ & $29 a b$ & $0,8 \mathrm{a}$ & $10 \mathrm{c}$ & $3 \mathrm{a}$ & $14 \mathrm{~b}$ & $43 \mathrm{a}$ & $32 \mathrm{bc}$ \\
\hline Silicato de cálcio 2 & $4,2 \mathrm{~b}$ & $34 \mathrm{a}$ & 36 a & $0,7 \mathrm{a}$ & $10 \mathrm{c}$ & $4 \mathrm{a}$ & $14 \mathrm{~b}$ & $50 \mathrm{a}$ & $29 \mathrm{c}$ \\
\hline Silicato de cálcio e magnésio 1 & $4,5 \mathrm{a}$ & $40 \mathrm{a}$ & $29 \mathrm{ab}$ & $1,0 \mathrm{a}$ & $15 \mathrm{abc}$ & $5 \mathrm{a}$ & $20 \mathrm{ab}$ & $49 \mathrm{a}$ & $42 \mathrm{a}$ \\
\hline Silicato de cálcio e magnésio 2 & $4,3 \mathrm{ab}$ & 39 a & $31 \mathrm{ab}$ & $1,0 \mathrm{a}$ & $13 \mathrm{abc}$ & $4 \mathrm{a}$ & $17 \mathrm{ab}$ & $49 \mathrm{a}$ & $36 \mathrm{abc}$ \\
\hline Wollastonita 1 & $4,4 \mathrm{ab}$ & $40 \mathrm{a}$ & $31 a b$ & $1,0 \mathrm{a}$ & $15 \mathrm{ab}$ & $4 \mathrm{a}$ & $20 \mathrm{ab}$ & $50 \mathrm{a}$ & $39 a b$ \\
\hline Calcário dolomítico 1 & $4,4 \mathrm{ab}$ & $22 \mathrm{a}$ & $27 \mathrm{~b}$ & $0,9 \mathrm{a}$ & $11 \mathrm{bc}$ & $5 \mathrm{a}$ & $17 \mathrm{ab}$ & $43 \mathrm{a}$ & $38 \mathrm{abc}$ \\
\hline CV $(\%)$ & 2,6 & 27,7 & 11,1 & 31,5 & 16,1 & 22,4 & 16,8 & 10,0 & 10,7 \\
\hline
\end{tabular}


O teor de cálcio foi superior quando aplicado a escória 1; este fato foi observado também no LVd e no NVe nas duas amostragens.

Comparando a dose calculada com o PRNT laboratório e com o PRNT experimento, para os valores de $\mathrm{pH}, \mathrm{H}+\mathrm{Al}, \mathrm{Ca}, \mathrm{Mg}, \mathrm{SB}, \mathrm{CTC}$ e V\%, obteve-se diferença entre essas doses apenas na primeira amostragem para a escória, sendo o PRNT laboratório superior ao experimento (Tabela 40).

\subsubsection{Variáveis da planta}

Houve diferença significativa entre os tratamentos na produção de matéria seca da parte aérea da alfafa, apenas no segundo corte (Tabela 42).

Tabela 42 - Matéria seca de parte aérea da alfafa, no primeiro corte (C1) e no segundo corte (C2) em função dos tratamentos no Neossolo Quartzarênico (NQ).

\begin{tabular}{lcc}
\hline \multirow{2}{*}{ Tratamentos } & \multicolumn{2}{c}{ Matéria Seca $(\mathrm{g})$} \\
\cline { 2 - 3 } Escória1 & $\mathrm{C} 1 \mathrm{C} 2$ \\
\cline { 2 - 3 } Escória 2 & $18,80 \mathrm{a}$ & $10,89 \mathrm{bc}$ \\
Silicato de cálcio 1 & $19,78 \mathrm{a}$ & $9,68 \mathrm{c}$ \\
Silicato de cálcio 2 & $20,10 \mathrm{a}$ & $12,58 \mathrm{~b}$ \\
Silicato de cálcio e magnésio 1 & $20,15 \mathrm{a}$ & $12,47 \mathrm{~b}$ \\
Silicato de cálcio e magnésio 2 & $19,65 \mathrm{a}$ & $11,32 \mathrm{bc}$ \\
Wollastonita 1 & $20,63 \mathrm{a}$ & $12,64 \mathrm{~b}$ \\
Calcário dolomítico 1 & $19,95 \mathrm{a}$ & $10,59 \mathrm{bc}$ \\
\hline CV (\%) & $20,23 \mathrm{a}$ & $15,72 \mathrm{a}$ \\
\hline Médias seguidas de mesma letra não diferem entre si pelo teste de Tukey a $5 \%$ de probabilidade. 1: dose calculada a partir do PRNT \\
laboratório; 2: dose calculada a partir do PRNT experimento.
\end{tabular}

No primeiro corte o silicato de cálcio ficou bem próximo aos demais corretivos, sendo inclusive superior à escória, ao silicato de cálcio e magnésio 2 e à wollastonita, contudo essa superioridade não foi significativa. No segundo corte teve-se diferença significativa entre os tratamentos; todos os corretivos decresceram na produção de matéria seca em relação ao primeiro corte, no entanto verifica-se que o corretivo que menos diminuiu a produção de matéria seca foi o calcário, e neste corte novamente o silicato de cálcio foi um dos corretivos que mais produziu matéria seca. 
Os teores médios de nutrientes na parte aérea das plantas de alfafa obtidos no primeiro e segundo corte estão nas Tabelas 43 e 44, respectivamente. No primeiro corte, os tratamentos diferiram significativamente apenas nos teores de N e Mn. Já no segundo corte teve-se diferença significativa nos teores de P, Mg, Mn, Zn e B.

Tabela 43 - Teores médios de nutrientes na parte aérea de plantas de alfafa ( $1^{\circ}$ corte) em função dos tratamentos aplicados no Neossolo Quartzarênico (NQ).

\begin{tabular}{|c|c|c|c|c|c|c|c|c|c|c|c|}
\hline Tratamentos & $\mathrm{N}$ & $\mathrm{P}$ & $\mathrm{K}$ & $\mathrm{Ca}$ & $\mathrm{Mg}$ & $\mathrm{S}$ & $\mathrm{Cu}$ & $\mathrm{Fe}$ & $\mathrm{Mn}$ & $\mathrm{Zn}$ & $\mathrm{B}$ \\
\hline & \multicolumn{6}{|c|}{ 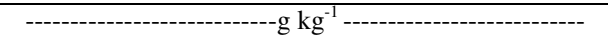 } & \multicolumn{5}{|c|}{ 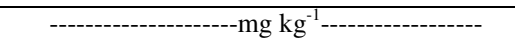 } \\
\hline Escória 1 & $28 \mathrm{ab}$ & $4,1 \mathrm{a}$ & $23 \mathrm{a}$ & $12 \mathrm{a}$ & $2,3 \mathrm{a}$ & $2,0 \mathrm{a}$ & $8 \mathrm{a}$ & $81 \mathrm{a}$ & $391 \mathrm{abc}$ & $86 a$ & $74 \mathrm{a}$ \\
\hline Escória 2 & $28 \mathrm{ab}$ & $3,8 \mathrm{a}$ & $24 \mathrm{a}$ & $13 \mathrm{a}$ & $2,4 \mathrm{a}$ & $2,1 \mathrm{a}$ & $9 \mathrm{a}$ & $89 \mathrm{a}$ & $379 \mathrm{bc}$ & $86 \mathrm{a}$ & $65 \mathrm{a}$ \\
\hline Silicato de cálcio 1 & $29 \mathrm{ab}$ & $4,4 \mathrm{a}$ & $23 \mathrm{a}$ & $10 \mathrm{a}$ & $2,5 \mathrm{a}$ & $2,2 \mathrm{a}$ & $8 \mathrm{a}$ & $95 \mathrm{a}$ & $568 \mathrm{ab}$ & $96 \mathrm{a}$ & $75 a$ \\
\hline Silicato de cálcio 2 & $33 \mathrm{ab}$ & $4,9 \mathrm{a}$ & $24 \mathrm{a}$ & $10 \mathrm{a}$ & $2,8 \mathrm{a}$ & $2,2 \mathrm{a}$ & $9 \mathrm{a}$ & $106 \mathrm{a}$ & $608 \mathrm{a}$ & $113 \mathrm{a}$ & $74 \mathrm{a}$ \\
\hline Silicato de cálio e magnésio 1 & $27 \mathrm{~b}$ & $4,3 \mathrm{a}$ & $24 \mathrm{a}$ & $12 \mathrm{a}$ & $2,7 \mathrm{a}$ & $2,1 \mathrm{a}$ & $7 \mathrm{a}$ & $87 \mathrm{a}$ & $321 \mathrm{c}$ & $82 \mathrm{a}$ & $64 \mathrm{a}$ \\
\hline Silicato de cálcio e magnésio 2 & $30 \mathrm{ab}$ & $4,6 \mathrm{a}$ & 26 a & $10 \mathrm{a}$ & $2,8 \mathrm{a}$ & $2,3 \mathrm{a}$ & $8 \mathrm{a}$ & 96 a & $452 \mathrm{abc}$ & $93 \mathrm{a}$ & $56 \mathrm{a}$ \\
\hline Wollastonita 1 & $29 \mathrm{ab}$ & $4,2 \mathrm{a}$ & $23 \mathrm{a}$ & $12 \mathrm{a}$ & $2,3 \mathrm{a}$ & $1,9 \mathrm{a}$ & $8 \mathrm{a}$ & 94 a & $258 \mathrm{c}$ & $80 \mathrm{a}$ & $68 \mathrm{a}$ \\
\hline Calcário dolomítico 1 & $35 \mathrm{a}$ & $4,7 \mathrm{a}$ & $25 \mathrm{a}$ & $9 \mathrm{a}$ & 3,1 a & $2,2 \mathrm{a}$ & $8 \mathrm{a}$ & $108 \mathrm{a}$ & $378 \mathrm{bc}$ & $70 \mathrm{a}$ & $62 \mathrm{a}$ \\
\hline $\mathrm{CV}(\%)$ & 10,7 & 13,8 & 10,5 & 19,1 & 12,7 & 11,4 & 24,8 & 17,2 & 21,9 & 27,1 & 13,8 \\
\hline
\end{tabular}

Médias seguidas de mesma letra não diferem entre si pelo teste de Tukey a 5\% de probabilidade. 1: dose calculada a partir do PRNT laboratório; 2: dose calculada a partir do PRNT experimento.

No primeiro corte o calcário dolomítico proporcionou o maior teor de nitrogênio e diferiu apenas do silicato de cálcio e magnésio 1. Verifica-se que o teor deste nutriente encontra-se abaixo da faixa adequada para a alfafa (RAIJ et al., 1996).

Tabela 44 - Teores médios de nutrientes na parte aérea de plantas de alfafa ( $2^{\circ}$ corte) em função dos tratamentos aplicados no Neossolo Quartzarênico (NQ).

\begin{tabular}{|c|c|c|c|c|c|c|c|c|c|c|c|}
\hline Tratamentos & $\mathrm{N}$ & $\mathrm{P}$ & $\mathrm{K}$ & $\mathrm{Ca}$ & $\mathrm{Mg}$ & $\mathrm{S}$ & $\mathrm{Cu}$ & $\mathrm{Fe}$ & $\mathrm{Mn}$ & $\mathrm{Zn}$ & $\mathrm{B}$ \\
\hline & \multicolumn{6}{|c|}{------------------------------'g kg } & \multicolumn{5}{|c|}{---------------------'mg kg'-1----------------- } \\
\hline Escória 1 & $17 \mathrm{a}$ & $6,2 \mathrm{ab}$ & $22 \mathrm{a}$ & $19 \mathrm{a}$ & $3,5 \mathrm{ab}$ & $2,8 \mathrm{a}$ & $11 \mathrm{a}$ & $444 \mathrm{a}$ & 553 cde & $165 \mathrm{bc}$ & $97 \mathrm{ab}$ \\
\hline Escória 2 & $21 \mathrm{a}$ & $7,4 \mathrm{ab}$ & $26 \mathrm{a}$ & $18 \mathrm{a}$ & $3,9 \mathrm{ab}$ & $3,0 \mathrm{a}$ & $10 \mathrm{a}$ & $417 \mathrm{a}$ & $810 \mathrm{ab}$ & $222 \mathrm{a}$ & $91 \mathrm{ab}$ \\
\hline Silicato de cálcio 1 & $20 \mathrm{a}$ & $7,1 \mathrm{ab}$ & $23 \mathrm{a}$ & $15 \mathrm{a}$ & $3,7 \mathrm{ab}$ & $3,0 \mathrm{a}$ & $10 \mathrm{a}$ & $380 \mathrm{a}$ & $772 \mathrm{abc}$ & $173 \mathrm{abc}$ & $75 \mathrm{ab}$ \\
\hline Silicato de cálcio 2 & $19 \mathrm{a}$ & 7,9 a & $23 \mathrm{a}$ & $15 \mathrm{a}$ & $3,9 \mathrm{ab}$ & $3,0 \mathrm{a}$ & $10 \mathrm{a}$ & 499 a & $864 \mathrm{a}$ & $199 \mathrm{ab}$ & $76 \mathrm{~b}$ \\
\hline Silicato de cálcio e magnésio 1 & $17 \mathrm{a}$ & $6,2 \mathrm{ab}$ & $23 \mathrm{a}$ & $20 \mathrm{a}$ & $4,3 \mathrm{ab}$ & $2,8 \mathrm{a}$ & $10 \mathrm{a}$ & $474 \mathrm{a}$ & 439 de & $153 \mathrm{bc}$ & $101 \mathrm{a}$ \\
\hline Silicato de cálcio e magnésio 2 & $19 \mathrm{a}$ & $7,2 \mathrm{ab}$ & $21 \mathrm{a}$ & $19 \mathrm{a}$ & $6,3 \mathrm{a}$ & $2,9 \mathrm{a}$ & $10 \mathrm{a}$ & $393 \mathrm{a}$ & $672 \mathrm{abcd}$ & $180 \mathrm{abc}$ & $83 \mathrm{ab}$ \\
\hline Wollastonita 1 & $17 \mathrm{a}$ & $5,9 \mathrm{~b}$ & $21 \mathrm{a}$ & $19 \mathrm{a}$ & $3,4 \mathrm{~b}$ & $2,6 \mathrm{a}$ & $11 \mathrm{a}$ & $386 \mathrm{a}$ & $372 \mathrm{e}$ & $142 \mathrm{c}$ & $97 \mathrm{ab}$ \\
\hline Calcário dolomítico 1 & $23 \mathrm{a}$ & $7,0 \mathrm{ab}$ & $18 \mathrm{a}$ & $16 \mathrm{a}$ & $4,6 \mathrm{ab}$ & $2,5 \mathrm{a}$ & $11 \mathrm{a}$ & $336 \mathrm{a}$ & 598 bcde & $133 \mathrm{c}$ & $93 \mathrm{ab}$ \\
\hline $\mathrm{CV}(\%)$ & 25,1 & 11,5 & 16,0 & 13,8 & 29,4 & 14,0 & 12,0 & 30,3 & 15,5 & 14,0 & 11,0 \\
\hline
\end{tabular}

Médias seguidas de mesma letra não diferem entre si pelo teste de Tukey a 5\% de probabilidade. 1: dose calculada a partir do PRNT laboratório; 2: dose calculada a partir do PRNT experimento. 
Comparando os dois cortes, percebe-se que o teor de nitrogênio reduziu em relação ao primeiro corte, entretanto o teor de $\mathrm{P}, \mathrm{Ca}, \mathrm{Mg}, \mathrm{S}, \mathrm{Cu}, \mathrm{Fe}, \mathrm{Mn}, \mathrm{Zn}$ e B elevou-se no segundo corte, como já observado e discutido para o LVd e NVe.

$\mathrm{O}$ acúmulo médio de nutrientes na parte aérea da alfafa obtido no primeiro e segundo corte está nas Tabelas 45 e 46, respectivamente.

Tabela 45 - Acúmulo médio de nutrientes na parte aérea de plantas de alfafa ( $1^{\circ}$ corte) em função dos tratamentos aplicados no Neossolo Quartzarênico (NQ).

\begin{tabular}{|c|c|c|c|c|c|c|}
\hline Tratamentos & $\mathrm{N}$ & $\mathrm{P}$ & $\mathrm{K}$ & $\mathrm{Ca}$ & $\mathrm{Mg}$ & $S$ \\
\hline & & & ---mg por & aso ------- & & \\
\hline Escória 1 & $513,6 \mathrm{a}$ & $70,6 \mathrm{a}$ & 413,4 a & 225,9 a & $43,6 \mathrm{a}$ & $35,9 \mathrm{a}$ \\
\hline Escória 2 & $542,3 \mathrm{a}$ & $75,1 \mathrm{a}$ & $466,4 \mathrm{a}$ & $263,6 \mathrm{a}$ & $46,2 \mathrm{a}$ & $40,6 \mathrm{a}$ \\
\hline Silicato de cálcio 1 & $586,3 \mathrm{a}$ & 89,3 a & $466,4 \mathrm{a}$ & $196,2 \mathrm{a}$ & $50,3 \mathrm{a}$ & $44,4 \mathrm{a}$ \\
\hline Silicato de cálcio 2 & $657,1 \mathrm{a}$ & $100,8 \mathrm{a}$ & $493,2 \mathrm{a}$ & 196,6 a & $55,5 \mathrm{a}$ & $44,7 \mathrm{a}$ \\
\hline Silicato de cálcio e magnésio 1 & 533,8 a & $85,0 \mathrm{a}$ & 471,6 a & $225,7 \mathrm{a}$ & $53,5 \mathrm{a}$ & $40,2 \mathrm{a}$ \\
\hline Silicato de cálcio e magnésio 2 & $610,5 \mathrm{a}$ & $93,8 \mathrm{a}$ & 523,7 a & $195,1 \mathrm{a}$ & $57,1 \mathrm{a}$ & $46,0 \mathrm{a}$ \\
\hline Wollastonita 1 & 577,9 a & $83,0 \mathrm{a}$ & 458,4 a & $246,6 \mathrm{a}$ & $46,2 \mathrm{a}$ & $37,2 \mathrm{a}$ \\
\hline Calcário dolomítico 1 & $710,4 \mathrm{a}$ & $96,5 \mathrm{a}$ & $502,4 \mathrm{a}$ & $188,3 \mathrm{a}$ & $63,1 \mathrm{a}$ & $44,3 \mathrm{a}$ \\
\hline $\mathrm{CV}(\%)$ & 14,3 & 18,0 & 14,1 & 26,1 & 17,0 & 12,3 \\
\hline Tratamentos & $\mathrm{Cu}$ & $\mathrm{Fe}$ & $\mathrm{Mn}$ & $\mathrm{Zn}$ & \multicolumn{2}{|c|}{$\mathrm{B}$} \\
\hline & \multicolumn{6}{|c|}{ - } \\
\hline Escória 1 & $0,15 \mathrm{a}$ & $1,50 \mathrm{a}$ & $7,35 \mathrm{bc}$ & 1,60 & \multicolumn{2}{|c|}{$1,38 \mathrm{a}$} \\
\hline Escória 2 & $0,17 \mathrm{a}$ & $1,76 \mathrm{a}$ & $7,06 \mathrm{bc}$ & 1,61 & \multicolumn{2}{|c|}{$1,25 \mathrm{a}$} \\
\hline Silicato de cálcio 1 & $0,16 \mathrm{a}$ & $1,93 \mathrm{a}$ & $11,49 \mathrm{ab}$ & 1,92 & \multicolumn{2}{|c|}{$1,50 \mathrm{a}$} \\
\hline Silicato de cálcio 2 & $0,17 \mathrm{a}$ & $2,11 \mathrm{a}$ & $12,18 \mathrm{a}$ & 2,21 & \multicolumn{2}{|c|}{$1,48 \mathrm{a}$} \\
\hline Silicato de cálcio e magnésio 1 & $0,13 \mathrm{a}$ & $1,71 \mathrm{a}$ & $6,30 \mathrm{c}$ & 1,61 & \multicolumn{2}{|c|}{$1,25 \mathrm{a}$} \\
\hline Silicato de cálcio e magnésio 2 & $0,16 \mathrm{a}$ & $1,96 \mathrm{a}$ & $9,24 \mathrm{abc}$ & 1,86 & \multicolumn{2}{|c|}{$1,15 \mathrm{a}$} \\
\hline Wollastonita 1 & $0,16 \mathrm{a}$ & $1,89 \mathrm{a}$ & $5,16 \mathrm{c}$ & 1,59 & \multicolumn{2}{|c|}{$1,36 \mathrm{a}$} \\
\hline Calcário dolomítico 1 & $0,18 \mathrm{a}$ & $2,18 \mathrm{a}$ & $7,63 \mathrm{abc}$ & 1,42 & \multicolumn{2}{|c|}{$1,26 \mathrm{a}$} \\
\hline $\mathrm{CV}(\%)$ & 26,0 & 21,8 & 23,2 & 20,5 & \multicolumn{2}{|c|}{13,9} \\
\hline
\end{tabular}

Médias seguidas de mesma letra não diferem entre si pelo teste de Tukey a 5\% de probabilidade. 1: dose calculada a partir do PRNT laboratório; 2: dose calculada a partir do PRNT experimento.

No primeiro corte houve diferença significativa entre os tratamentos apenas no acúmulo de $\mathrm{Mn}$. No segundo corte ocorreu diferença significativa entre os tratamentos no acúmulo de $\mathrm{N}, \mathrm{P}, \mathrm{Ca}, \mathrm{Mg}, \mathrm{Cu}, \mathrm{Mn}$ e $\mathrm{Zn}$.

No segundo corte, a aplicação do calcário dolomítico promoveu o maior acúmulo de $\mathrm{N}$ e P. Para o Mg o maior valor de acúmulo foi obtido com a aplicação do 
silicato de cálcio e magnésio 2 e calcário dolomítico, e percebe-se que o acúmulo destes nutrientes elevaram-se do primeiro para o segundo corte. Para os demais nutrientes, exceto o $\mathrm{P}$ e o $\mathrm{Zn}$, ocorreu diminuição do acúmulo obtido no segundo corte em relação ao primeiro (Tabelas 45 e 46).

Tabela 46 - Acúmulo médio de nutrientes na parte aérea de plantas de alfafa ( $2^{\circ}$ corte) em função dos tratamentos aplicados no Neossolo Quartzarênico (NQ).

\begin{tabular}{|c|c|c|c|c|c|c|}
\hline Tratamentos & $\mathrm{N}$ & $\mathrm{P}$ & $\mathrm{K}$ & $\mathrm{Ca}$ & $\mathrm{Mg}$ & $S$ \\
\hline Escória 1 & $178,8 \mathrm{~b}$ & $67,9 \mathrm{c}$ & $\begin{array}{l}237,8 \mathrm{a} \\
\text {---mg por }\end{array}$ & $\begin{array}{r}\text { vaso ------- } \\
198,1 \mathrm{ab}\end{array}$ & $37,5 \mathrm{bc}$ & $29,3 \mathrm{a}$ \\
\hline Escória 2 & $208,7 \mathrm{ab}$ & $71,1 \mathrm{bc}$ & 249,9 a & $176,0 \mathrm{~b}$ & $37,6 \mathrm{bc}$ & $29,1 \mathrm{a}$ \\
\hline Silicato de cálcio 1 & $248,8 \mathrm{ab}$ & $89,4 \mathrm{abc}$ & $285,2 \mathrm{a}$ & $191,2 \mathrm{ab}$ & 46,4 & $37,8 \mathrm{a}$ \\
\hline Silicato de cálcio 2 & $237,3 \mathrm{ab}$ & $98,3 \mathrm{ab}$ & $290,7 \mathrm{a}$ & $184,6 a b$ & 48,0 & $36,6 \mathrm{a}$ \\
\hline Silicato de cálcio e magnésio 1 & $192,9 \mathrm{ab}$ & 71,4 bc & $253,4 \mathrm{a}$ & $225,8 \mathrm{ab}$ & 48,0 & $30,8 \mathrm{a}$ \\
\hline Silicato de cálcio e magnésio 2 & $242,9 \mathrm{ab}$ & $90,7 \mathrm{abc}$ & $257,2 \mathrm{a}$ & $234,4 a b$ & $78,8 \mathrm{a}$ & $36,3 \mathrm{a}$ \\
\hline Wollastonita 1 & $174,1 \mathrm{~b}$ & $61,5 \mathrm{c}$ & $217,8 \mathrm{a}$ & $203,0 \mathrm{ab}$ & $35,9 \mathrm{c}$ & $27,5 \mathrm{a}$ \\
\hline Calcário dolomítico 1 & $370,0 \mathrm{a}$ & $109,7 \mathrm{a}$ & 283,6 a & $254,6 \mathrm{a}$ & $71,0 \mathrm{ab}$ & $39,3 \mathrm{a}$ \\
\hline $\mathrm{CV}(\%)$ & 34,2 & 15,2 & 15,4 & 15,3 & 29,1 & 15,2 \\
\hline Tratamentos & $\mathrm{Cu}$ & $\mathrm{Fe}$ & $\mathrm{Mn}$ & $\mathrm{Zn}$ & \multicolumn{2}{|c|}{ B } \\
\hline & \multicolumn{6}{|c|}{ 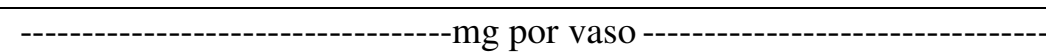 } \\
\hline Escória 1 & $0,12 \mathrm{ab}$ & $4,73 \mathrm{a}$ & $5,93 \mathrm{~cd}$ & $1,78 \mathrm{bc}$ & \multicolumn{2}{|c|}{$1,06 \mathrm{~b}$} \\
\hline Escória 2 & $0,09 \mathrm{~b}$ & $4,08 \mathrm{a}$ & $7,88 \mathrm{bc}$ & $2,14 \mathrm{abc}$ & \multicolumn{2}{|c|}{$0,87 \mathrm{~b}$} \\
\hline Silicato de cálcio 1 & $0,13 \mathrm{ab}$ & $4,81 \mathrm{a}$ & $9,61 \mathrm{ab}$ & $2,16 \mathrm{abc}$ & \multicolumn{2}{|c|}{$0,95 \mathrm{~b}$} \\
\hline Silicato de cálcio 2 & $0,13 \mathrm{ab}$ & $6,22 \mathrm{a}$ & $10,73 \mathrm{a}$ & $2,50 \mathrm{a}$ & \multicolumn{2}{|c|}{$0,94 \mathrm{~b}$} \\
\hline Silicato de cálcio e magnésio 1 & $0,12 \mathrm{ab}$ & $5,27 \mathrm{a}$ & $4,99 \mathrm{~d}$ & $1,70 \mathrm{bc}$ & \multicolumn{2}{|c|}{$1,14 \mathrm{ab}$} \\
\hline Silicato de cálcio e magnésio 2 & $0,13 \mathrm{ab}$ & $4,93 \mathrm{a}$ & $8,50 \mathrm{abc}$ & $2,27 \mathrm{ab}$ & \multicolumn{2}{|c|}{$1,05 \mathrm{~b}$} \\
\hline Wollastonita 1 & $0,12 \mathrm{ab}$ & $4,09 \mathrm{a}$ & $3,98 \mathrm{~d}$ & $1,51 \mathrm{c}$ & \multicolumn{2}{|c|}{$1,03 \mathrm{~b}$} \\
\hline Calcário dolomítico 1 & $0,16 \mathrm{a}$ & $5,29 \mathrm{a}$ & $9,36 \mathrm{ab}$ & $2,08 \mathrm{abc}$ & \multicolumn{2}{|c|}{$1,47 \mathrm{a}$} \\
\hline $\mathrm{CV}(\%)$ & 16,7 & 31,7 & 15,2 & 14,6 & \multicolumn{2}{|c|}{14,1} \\
\hline
\end{tabular}

Médias seguidas de mesma letra não diferem entre si pelo teste de Tukey a 5\% de probabilidade. 1: dose calculada a partir do PRNT laboratório; 2: dose calculada a partir do PRNT experimento. 


\section{CONSIDERAÇÕES FINAIS}

Os corretivos de acidez do solo, silicatos e calcários, mostraram diferenças entre si na velocidade de correção da acidez do solo, como já esperado tendo em vista, que estes corretivos possuem composição química e características físicas distintas.

No experimento 2, nota-se que para os calcários e a wollastonita o método da incubação empregado neste experimento não diferiu do método oficial para calcários. Entretanto para os demais silicatos (escória, silicato de cálcio e silicato de cálcio e magnésio) os métodos diferiram, podendo-se inferir que, para os silicatos, o método utilizado para silicatos não deve ser o mesmo que o dos calcários.

Com os dados do experimento 2, verificou-se superioridade dos silicatos, e os valores de eficiência relativa de reatividade de suas frações granulométricas foram superiores aos determinados pela legislação brasileira para calcários, desta forma poderia-se levantar a hipótese de que o cálculo da dose considerando o PRNT laboratório para os silicatos estaria superestimando a dose a ser aplicada, ou seja, elevaria o valor de V \% acima do desejado para a cultura. No entanto, essa hipótese no experimento 3 não foi confirmada, pois o valor de $\mathrm{V} \%$ não foi atingido. $\mathrm{O}$ mesmo também ocorreu com a dose calculada com o PRNT laboratório, que não atingiu o valor de V\% de 80. Provavelmente a saturação por bases dos solos desejada não foi atingida devido à amostragem do solo no $3^{\circ}$ experimento ter sido realizada com apenas 30 dias de incubação, lembrando que para os demais experimentos o período adotado foi sempre de 90 dias. 
No terceiro experimento verificou-se que as plantas de alfafa desenvolveram melhor nos tratamentos utilizando as doses calculadas pelo PRNT laboratório inferindo-se daí que os valores de reatividade adotados para calcários foram mais eficientes do que o experimental. 


\section{CONCLUSÕES}

As taxas de eficiência relativa para a reatividade dos silicatos foram superiores às determinadas pela legislação brasileira, sendo as frações granulométricas dos silicatos de cálcio e de cálcio e magnésio as que apresentaram os maiores valores de eficiência relativa. Para o calcário e a wollastonita os valores foram próximos aos vigentes na legislação brasileira. A reatividade dos corretivos variou com a classe do solo.

As doses de corretivos de acidez aplicadas utilizando os valores de PRNT determinado em laboratório e aquele obtido experimentalmente não proporcionaram a correção da acidez do solo desejada para o desenvolvimento das plantas de alfafa. 


\section{REFERÊNCIAS BIBLIOGRÁFICAS}

ALCARDE, J.A.; RODELLA, A.A. Qualidade e legislação de fertilizantes e corretivos. In: CURI, N.; MARQUES, J.J.; GUILHERME, L.R.G.; LIMA, J.M.; LOPES, A. S.; ALVARES V., V.H. Tópicos em Ciência do Solo. Viçosa, Sociedade brasileira de Ciência do Solo, p.291-334, 2003.

ALCARDE, J. C. Metodologia oficial de Análise de Corretivos de Acidez. Porto AlegreRS, 2009, 58p.

ALCARDE, J.C. Corretivos da acidez do solo: Características e interpretações técnicas. ASSOCIAÇÃO NACIONAL PARA DIFUSÃO DE ADUBOS E CORRETIVOS (ANDA), São Paulo - SP, 1992, 62p. (Boletim Técnico 6).

ALCARDE, J.C.; PAULINO, V.T.; DERNARDIN, J.S. Avaliação da reatividade de corretivos da acidez do solo. Revista Brasileira de Ciência do Solo, v.13, p.387-392, 1989.

ALCARDE, J.C.; RODELLA, A.A. O equivalente em carbonato de cálcio dos corretivos dos solos. Scientia Agrícola, v.53, n. 2-3, p. 204-210, 1996.

ALCARDE, P. A. A avaliação da qualidade dos corretivos da acidez dos solos. ASSOCIAÇÃO DOS PRODUTOS DE CALCÁRIO AGRÍCOLA DO ESTADO DE SÃO PAULO, Rio Claro - SP, 1986, 40p.

AMARAL, A. S.; DEFELIPO, B. V.; COSTA, L.M.; FONTES, M. P. F. Liberação de Zn, Fe, $\mathrm{Mn}$ e Cd de quatro corretivos da acidez e absorção por alface em dois solos. Pesquisa Agropecuária Brasileira, Brasília, v.29, n. 9, p.1345-1350, 1994. 
BELLINGIERI, P. A. Avaliação em Laboratório da eficiência de diferentes frações granulométricas de calcários agrícolas. 1983. 99 f. Tese (Doutorado) - Escola Superior de Agricultura Luiz de Queiroz, Universidade do Estado de São Paulo. Piracicaba, 1983. BELLINGIERI, P.A.; ALCARDE, J.C.; SOUZA, E.C.A. Eficiência relativa de diferentes frações granulométricas de calcários na neutralização da acidez dos solos, avaliada em laboratório. Anais da ESALQ, Piracicaba, v.46, p.303-317, 1989.

BRASIL, Ministério da Agricultura. Secretaria Nacional de Defesa Agropecuária. Portaria $\mathrm{N}^{\mathrm{o}}$ 31, de 8 de junho de 1986. Determina as características físicas, PN e PRNT mínimas dos corretivos da acidez do solo: classifica os calcários agrícolas em função do PRNT e determina como será calculado o PRNT. Diário Oficial, Brasília, 14 de junho de 1986. seção 1, p.10.790.

CORRÊA, J.C.; BÜLL, L.T.; CRUSCIOL, C.A.C.; MARCELINO, R.; MAUAD, M. Correção da acidez e mobilidade de íons em Latossolo com aplicação superficial de escória, lama cal, lodos de esgoto e calcário. Pesquisa Agropecuária Brasileira, Brasília, v.42, p.1307-1317, 2007.

EMPRESA BRASILEIRA DE PESQUISA AGROPECUÁRIA - EMBRAPA- Manual de métodos de análise de solo. Rio de Janeiro: Embrapa-CNPS, 1997. 212p

EMPRESA BRASILEIRA DE PESQUISA AGROPECUÁRIA - EMBRAPA- Sistema brasileiro de classificação dos solos. Brasília: Embrapa-CNPS, 1999. 412p

ERNANI, P. R. Química do solo e disponibilidade de nutrientes. Lages, 2008. 230p.

FERREIRA, D.F. Sisvar: versão 4.2. Lavras: UFLA, 2003.

KAMINSKI, J.; RHEINHEIMER, D.S. Acidez do solo e nutrição mineral das plantas. In: KAMINSKI, J. (Coord.). Uso de corretivos da acidez do solo no plantio direto. Pelotas: 
Núcleo Regional Sul da Sociedade Brasileira de Ciência do Solo, 2000. p.21-40. (Boletim n. 4).

KORNDÖRFER, G. H., PEREIRA, H. S., CAMARGO, M. S. de. Silicatos de cálcio e magnésio na agricultura. Uberlândia : GPSi, 2003. 15p. (Boletim Técnico $\mathrm{n}^{\circ}$ 1).

MALAVOLTA, E.; VITTI, G. C.; OLIVEIRA, S. A. Avaliação do estado nutricional das plantas: princípios e aplicações. 2.ed. ver. e atual. Piracicaba: Potafos, 1997. 319 p.

NATALE, W. e COUTINHO, E.L.M. Avaliação da eficiência agronômica de frações granulométricas de um calcário dolomítico. Revista Brasileira de Ciência do Solo, v. 18, p. 55-62, 1994.

OLIVEIRA, J.B. Pedologia aplicada, 2. ed. Piracicaba: FEALQ 2005. 574p.

PANDOLFO, C.M.; TEDESCO, M.J. Eficiência relativa de frações granulométricas de calcário na correção da acidez do solo. Pesquisa Agropecuária Brasileira, Brasília, v.3, p.753-758, 1996.

PAVAN, M.A.; OLIVEIRA, E.L. Corretivos da acidez do solo: experiências no Paraná. In: KAMINSKI, J. (Coord.). Uso de corretivos da acidez do solo no plantio direto. Pelotas: Núcleo Regional Sul da Sociedade Brasileira de Ciência do Solo, 2000. p.61-76. (Boletim, 4).

PIAU, W.C. Viabilidade do uso de escória como corretivo e fertilizante. 1991. 99f.

Dissertação (Mestrado em Agronomia) - Escola Superior de Agricultura Luiz de Queiroz, Universidade do Estado de São Paulo. Piracicaba, 1991.

PIAU, W. C. Efeitos de escórias de siderurgia em atributos químicos de solos e na cultura do milho (Zea mays L.). 1995. 124 f. Tese (Doutorado) - Escola Superior de Agricultura Luiz de Queiroz, Universidade do Estado de São Paulo. Piracicaba, 1995. 
PIMENTEL GOMES, F. Curso de estatística experimental. 13. ed. Piracicaba, Nobel, 1991. $468 \mathrm{p}$.

PRADO, R.M.; CORREAA, M. C. de M.; CINTRA, A. C. O.; NATALE, W. Resposta de mudas de goiabeira à aplicação de escória de siderurgia como corretivo de acidez do solo. Revista Brasileira de Fruticultura, Jaboticabal - SP, v.25, n. 1, p.160-163, 2003.

PRADO, R.M.; FERNANDES, F.M. Escória de siderurgia e calcário na correção da acidez do solo cultivado com cana-de-açúcar em vasos. Scientia Agricola, v.57, n.4, p. 739-744, 2000.

PRADO, R.M.; FERNANDES, F.M. Efeito da escória de siderurgia e calcário na disponibilidade de fósforo de um Latossolo Vermelho-Amarelo cultivado com cana-de-açúcar. Pesquisa Agropecuária Brasileira, Brasília, v.36, p.1199-1204, 2001.

PRADO, R.M.; FERNANDES, F.M.; NATALE, W. Uso agrícola da escória de siderurgia no Brasil - Estudos na cultura da cana-de-açúcar. Jaboticabal, Funep, 2001. 68p.

PRADO, R.M.; NATALE, W. Efeitos da aplicação da escória de siderurgia ferrocromo no solo, no estado nutricional e na produção de matéria seca de mudas de maracujazeiro. Revista Brasileira de Fruticultura, Jaboticabal, v. 26, p. 140-144, 2004.

PRADO, R.M.; NATALE, W.; FERNANDES, F.M.; CORREAA, M. C. M. Reatividade de uma escória de siderurgia em um Latossolo Vermelho distrófico. Revista Brasileira de Ciência do Solo, Viçosa, v.28, p.197-205, 2004.

QUAGGIO, J.A. Acidez e calagem em solos tropicais. Campinas: Instituto Agronômico, 2000. 111p. 
RAIJ, B.van. Avaliação da fertilidade do solo. Piracicaba, POTAFOS, 1983. 142 p.

RAIJ, B. van; ANDRADE, J.C.; CANTARELLA, H.; QUAGGIO, J.A. Análise química para avaliação da fertilidade de solos tropicais. Campinas, Instituto Agronômico, 2001. $285 \mathrm{p}$.

RAIJ, B. van; SILVA, N. M.; BATAGLIA, O. C.; QUAGGIO, J. A.; HIROCE, R.; CATARELLA, H.; BELLINAZZI JR., R.; DECHEN, A. R.; TRANI, P. E. Recomendação de adubação e calagem para o Estado de São Paulo. Campinas: IAC, 1996. 285p. (Boletim técnico, 100).

VERLENGIA, F.; GARGANTINI, H. Estudo sobre a eficiência de diferentes frações granulométricas de calcário no solo. Bragantia, v. 31, n. 10, p. 119-128, 1972.

VITTI, G. C.; LUZ, P. H. C.; LEÃO, H. C.; SILVA, M. M. Técnicas de utilização de calcário e gesso na cultura do citros. In: SEMINÁRIO INTERNACIONAL DE CITROS, 4, 1996, Campinas. Anais... Campinas: Fundação Cargill, 1996. p.131-160

WUTKE, A.C.P.; GARGANTINI, H. Avaliação das possibilidades de escórias de siderurgia como corretivos da acidez do solo. Bragantia, Campinas, v.21, p.795-805, 1962. 